\title{
Elīna Sīvina
}

\section{Metastātiska kolorektālā vēža klīniskie un ǵenētiskie prognostiskie un prediktivie marḳieri}

Promocijas darbs zinātniskā doktora grāda "zinātnes doktors (Ph.D.)" iegūšanai

Nozare - klīniskā medicina Apakšnozare - onkoloǵija

Rīga, 2020 


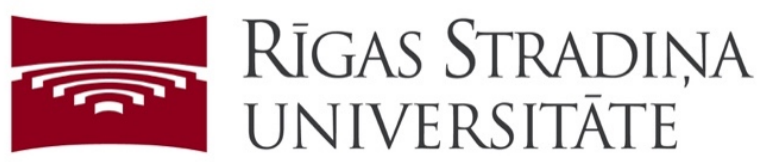

Elīna Sīvina

ORCID 0000-0001-5122-8679

Metastātiska kolorektālā vēža klīniskie un ǵenētiskie prognostiskie un prediktīvie marķieri

\author{
Promocijas darbs zinātniskā doktora grāda \\ "zinātnes doktors" (Ph.D.) iegūšanai
}

\author{
Nozare - klīniskā medicīna \\ Apakšnozare - onkolog̣ija
}

Darba zinātniskie vadītāji:

Dr. biol. profesors Edvīns Miklaševičs, RSU Onkologiijas institūts Dr. med. profesore Gunta Purkalne, PSKUS Onkolog̣ijas klīnika 


\section{Anotācija}

Kolorektālais vēzis ir viens no izplatītākajiem audzējiem pasaulē. Lai arī agrīna kolorektālā vēža ārstēšanas rezultāti pēdējās desmitgadēs ir ievērojami uzlabojušies, aizvien vēl nav pieejama efektīva metastātiska kolorektālā vēža (mKRV) ārstēšana. Ir arvien vairāk pierādījumu, ka kolorektālais vēzis ir ǵenētiski heterogēna audzēju grupa, kurus vieno anatomiskā lokalizācija resnajā zarnā. Slimības agresivitāti un prognozi nosaka gan kolorektālā vēža rašanās onkoğenēzes ceḷš, gan audzēja lokalizācija, izplatība, molekulāri ğenētiskās izmaiņas, audzēja mikrovide un stroma, kā arī zarnas mikrobioms. Izprotot kolorektālā vēža rašanās un progresēšanas mehānismus, mums ir iespēja precīzāk piemeklēt katram pacientam atbilstošu ārstēšanas veidu un pagarināt dzīvildzi.

Darba mērķis. Pētījuma mērḳis bija pierādīt, ka audzēja klīniskos rādītājus un audzēja hromosomālās izmaiņas var izmantot kā prognostiskus un prediktīvus faktorus pacientiem ar metastātisku kolorektālo vēzi (mKRV).

Darba metodes. Lai sasniegtu mērķi, promocijas darbs tika sadalīts trīs daḷās. Pirmajā pētījuma daḷā tika analizēti mKRV pacientu klīniskie un demogrāfiskie rādītāji (vecums, slimības diagnosticēšanas gads, ḳīmijterapijas veids un terapijas līniju skaits, metastāžu lokalizācija) un to ietekme uz bezprogresijas un kopējo izdzīvotību. Retrospektīvajā analīzē ieklauti 220 pacienti ar mKRV, kas saṇema k̦īmijterapiju laika posmā no 2004. līdz 2016.gadam. Otrajāa, prospektīvajā, pētījuma dạ̣a tika analizēta divu klīnisko parametru neitropēnija un laika intervāls līdz trešās līnijas k,īmijterapijas uzsākšanai - ietekme uz bezprogresijas izdzīvotību 14 pacientiem ar refraktāru mKRV, kuri saṇēma trifluridīna/tipiracila (FTD/TPI) terapiju laika posmā no 2016. gada aprīla līdz 2017. gada janvārim PSKUS un RAKUS/LOC. Trešajā, prospektīvajā, pētījuma daḷā tika analizētas masīvas hromosomālās fragmentācijas (chromothripsis) ietekme uz bezprogresijas izdzīvotību mKRV pacientiem, kas saṇēma pirmās līnijas k,īmijterapiju ar FOLFOX laika posmā no 2011. gada līdz 2012. gadam, kā arī analizētas biežākās gēnu delēcijas.

Darba rezultāti. Pētījuma rezultāti liecina, ka nerezecējama mKRV pacientu ārstēšana PSKUS un RAKUS/LOC un viņu izdzīvotība ir līdzīga publicēto pētījumu datiem. Netika konstatēta izdzīvotības atškirība pacientiem ar sinhronu vai metahronu mKRV, bet ievērojami labāka kopējā izdzīvotība (OS) konstatēta pacientiem, kuri saṇēma vairāk par vienu k̦īmijterapijas līniju (HR 0,36; p < 0,0001), kā arī pacientiem, kas jaunāki par 50 gadiem (HR 0,49; p = 0,0002). Sliktāka kopējā izdzīvotība bija pacientiem ar multiplām metastāzēm $(\mathrm{p}=0,059)$. 
Pacientiem ar refraktāru mKRV, kas saṇēma FTD/TPI terapiju, konstatēti divi pozitīvi klīniskie prediktīvie marķieri - neitropēnija terapijas saņemšanas laikā un laiks no slimības diagnosticēšanas brīža līdz FTD/TPI uzsākšanai vairāk par 18 mēnešiem. Pagarināta mPFS (HR $0,24, \mathrm{p}=0,033)$ un mOS (HR 0,25; p = 0,075) konstatēta pacientiem ar 3. un 4. pakāpes neitropēniju. Līdzīgi, labāka mPFS (HR 0,15; p = 0,029) un $\operatorname{mOS}(\operatorname{HR} 0,23 ; p=0,069)$ konstatēta pacientiem ar iepriekšējās terapijas ilgumu vairāk par 18 mēnešiem.

Augsts DNS lūzumpunktu nestabilitātes indekss (LNI) un chromothripsis ir pozitīvs prediktīvs mark,ieris mKRV pacientiem, kas saṇēma paliatīvu pirmās līnijas FOLFOX tipa ķ1̄mijterapiju. Pacientiem bez chromothripsis mPFS bija īsāka (HR 3,43; p =0,03), bet netika konstatēta ietekme uz kopējo izdzīvotību.

Secinājumi. Minētā atrade ḷauj secināt, ka mKRV klīniskie un ğenētiskie faktori var tikt izmantoti, lai prognozētu terapijas efektivitāti un slimības gaitu.

Atslēgvārdi. Metastātisks kolorektāls vēzis, chromothripsis, triflurid̄̄ns/tipiracils, prognostiskie markieri, prediktīvie mark,ieri. 


\section{Summary}

\section{Metastatic colorectal cancer clinical and genetic prognostic and predictive factors}

Colorectal cancer is one of the most common cancer types in the world. Although the results of early colorectal cancer treatment have improved significantly in recent decades, no effective therapy is currently available for advanced or metastatic disease. From a genetic standpoint, colorectal cancer is not a single disease, but a heterogeneous group of malignancies arising within the colon. Prognosis of mCRC is determined by oncogenetic pathway, localization of the primary tumour, molecular genetics of cancer, microenvironment and tumour stroma, and host microbiome. The progress in clinical and molecular studies have determined mechanisms of development and progression of colorectal cancer, and also helped to define most effective treatment strategy for each patent to prolong survival.

Aim of the study was to demonstrate that both the clinical factors and chromosomal aberrations can be used as a prognostic and predictive factors in patients with metastatic colorectal cancer.

Methods. The promotion work consists of three separate studies. In the first study, clinical factors (age, year of diagnosis, type of chemotherapy and number of treatment lines, localization of metastases) and their impact on progression free survival (PFS) and overall survival (OS) were analysed. $220 \mathrm{mCRC}$ patients who received chemotherapy between 2004 and 2016 in P.Stradins CUH Clinic of Oncology (PSCUH) were included in retrospective study. In the second, prospective study, the impact of clinical factors - such as neutropenia and duration of previous treatment - on progression free survival in 14 patients with refractory mCRC receiving trifluridine/tipiracil (FTD/TPI) from April 2016 to January 2017 in PSCUH and RECUH/LOC were analysed. In the third, prospective study, impact of massive chromosomal fragmentation chromothripsis on progression free survival in 19 mCRC patients receiving first line FOLFOX chemotherapy in 2011-2012 were analysed.

Results. The results of our study revealed that treatment strategy and survival of patients with unresectable mCRC is equal to data from published clinical studies. There was no significant difference in survival between synchronous and metachronous mCRC. Improved overall survival (OS) was observed in patients receiving more than one line of chemotherapy (HR 0.49; $\mathrm{p}=0.0002$ ), and in patient $<50$ years (HR 0.49; $\mathrm{p}=0.0002)$, but decreased OS was observed in patients with multiple metastases $(\mathrm{p}=0.059)$.

In patients with refractory $\mathrm{mCRC}$ receiving FTD/TPI treatment, two positive clinical predictive markers were identified - neutropenia and duration of previous treatment 
$>18$ months. Increased mPFS (HR 0.24; $p=0.033)$ and $\operatorname{mOS}(\operatorname{HR} 0.25 ; p=0.075)$ was observed in patients with Grade 3 and 4 neutropenia. Similarly, increased mPFS (HR 0.15; $\mathrm{p}=0.029)$ and $\mathrm{mOS}(\mathrm{HR} 0.23 ; \mathrm{p}=0.069)$ was observed in patients with duration of previous treatment $>18$ months.

High breakpoint instability index (BPI) and chromothripsis are positive predictive markers in mCRC patients receiving first line FOLFOX chemotherapy. In patients without chromothripsis, mPFS was decreased (HR 3.43; $\mathrm{p}=0.03$ ), but the impact on OS was not detected.

Conclusion. Different clinical and genetic factors may be used as a predictive and prognostic markers in treatment of mCRC.

Keywords. Metastatic colorectal cancer, chromothripsis, trifluridine/tipiracil, prognostic makers, predictive markers. 


\section{Saturs}

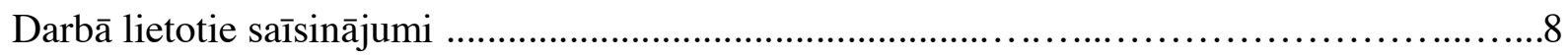

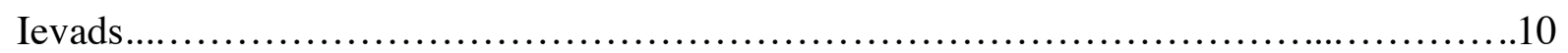

Problēmas aktualitāte ................................................................ 10

Darba mērkis...............................................................10

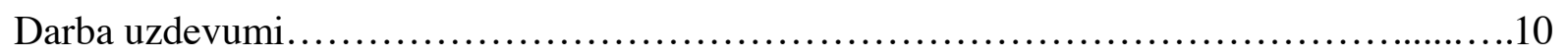

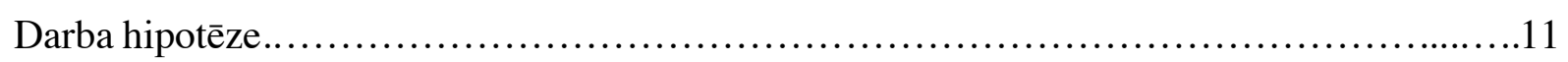

Pẹtījuma zinātniskā novitāte..................................................11

Sadarbības partneri un materiāli tehniskais nodrošinājums..............................11

Darba struktūra un autora personīgais ieguldījums...................................11

Ëtiskie aspekti.............................................................. 12

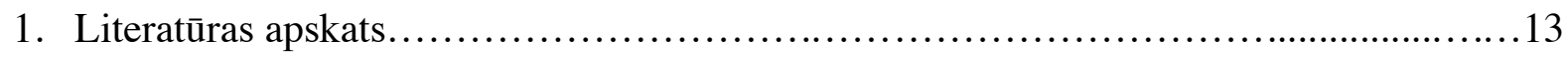

1.1. Kolorektālā vēža epidemiolog̣ija.......................................13

1.2. Kolorektālā vēža etiolog̣ija...............................................16

1.3. Kolorektālā vēža onkoǵenēze...........................................17

1.3.1. Sporādiska kolorektālā vēža onkoǵenēze.............................18

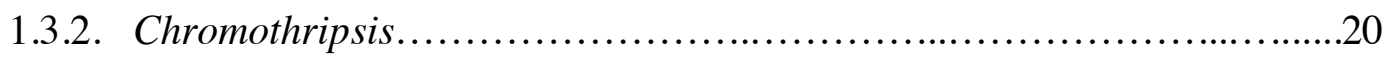

1.3.3. Pārmantota kolorektālā vēža onkoǵenēze.................................23

1.4. Kolorektālā vēža klasifikācija............................................25

1.5. Kolorektālā vēža molekulāri ǵenētiskais raksturojums......................29

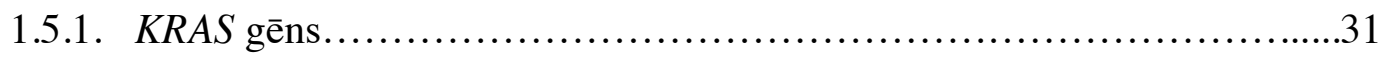

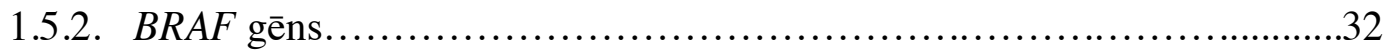

1.5.3. PI3K gēns......................................................... 33

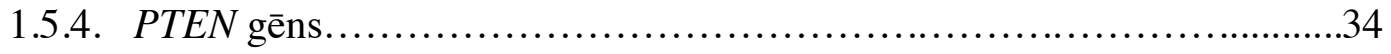

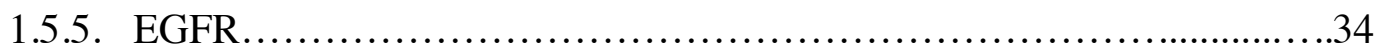

1.6. Vēlīns jeb metastātisks kolorektālais vēzis..................................35

1.7. Metastātiska kolorektālā vēža ārstēšana .....................................36

1.7.1. Rezecējama mKRV ārstēšana........................................36

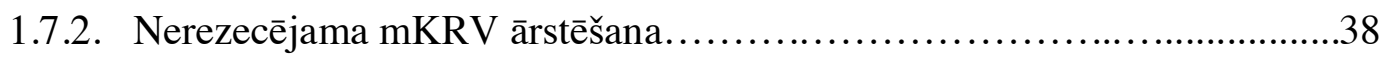

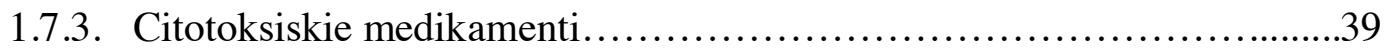

1.7.4. Mērḳa (bioloğiskā) terapija.......................................43

1.7.5. Ķīmijterapijas un mērķa terapijas secība metastātiska kolorektālā vēža ārstēšanā.

1.8. Metastātiska kolorektālā vēža terapijas efektivitātes rādītāji....................52

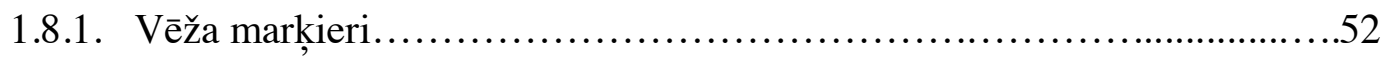

1.8.2. Radioloğiskie izmeklējumi........................................53 
1.8.3. Dzīvildze kā terapijas efektivitātes rādītājs .............................54

1.8.4. Cirkulējošie ǵenētiskie vēža markieri.................................55

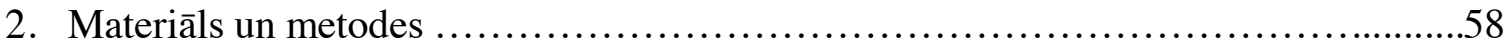

2.1. Nerezecējama mKRV analīze P.Stradiṇa KUS Onkoloğijas klīnikā..............58

2.2. Klīnisko prognostisko un prediktīvo faktoru analīze pacientiem, kas saṇem

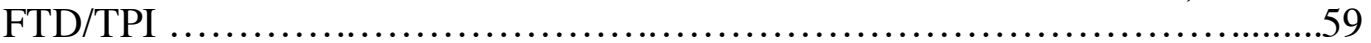

2.3. Chromothripsis kā metastātiska kolorektālā vēža prediktīvais faktors............60

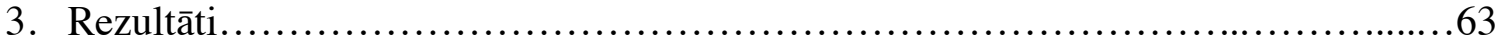

3.1. Nerezecējama mKRV analīze P.Stradiṇa KUS Onkoloğijas klīnikā ................63

3.2. Klīnisko prognostisko un prediktīvo faktoru analīze pacientiem, kas sanem

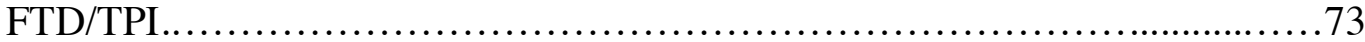

3.3. Chromothripsis kā metastātiska kolorektālā vēža prediktīvais faktors ..............75

3.4. Delēciju analīze pacientiem ar chromothripsis..................................81

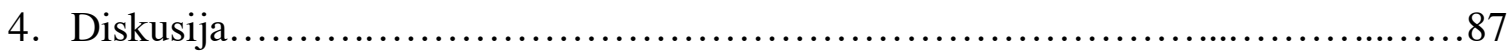

4.1. Nerezecējama mKRV analīze P.Stradina KUS Onkoloğijas klīnikā..............87

4.2. Klīnisko prognostisko un prediktīvo faktoru analīze pacientiem, kuri sanem FTD/TPI

4.3. Chromothripsis kā metastātiska kolorektālā vēža prediktīvais faktors ............91

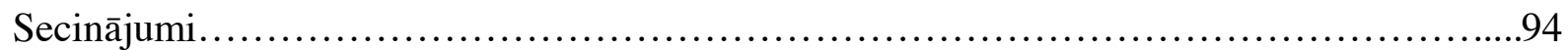

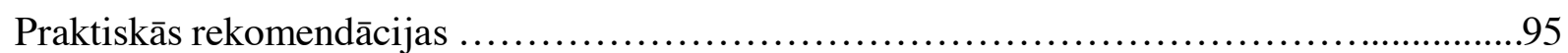

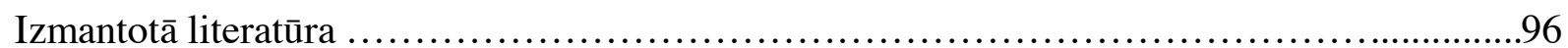

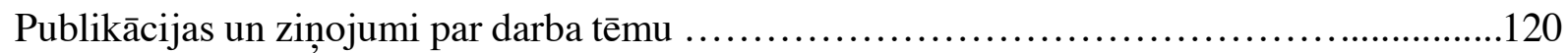

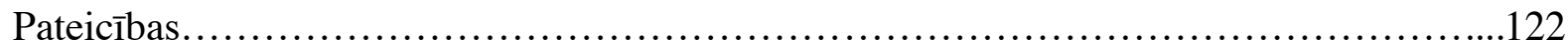

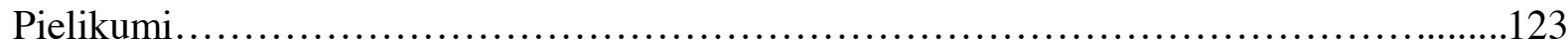

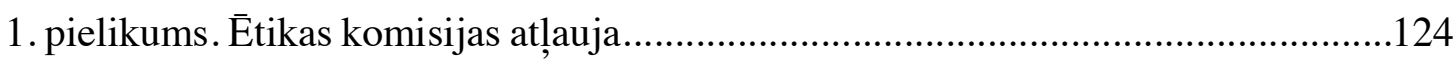

2. pielikums. Pacienta informācijas un piekrišanas veidlapa....................................125

3. pielikums. Pacienta piekrišanas veidlapa TAS-102 līdzjūtības zāḷu lietošanai........127

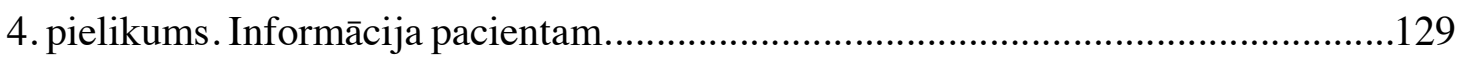




\section{Darbā lietotie saīsinājumi}

5-FU 5-fluoruracils

AJCC Amerikas Apvienotā vēža komiteja

American Joint Committee of

Cancer

$A P C \quad$ adenomatozās zarnu polipozes gēns

adenomatous polyposis coli (gene)

$B R A F \quad$ B-Raf protoonkogēns

B-Raf proto-oncogene, serine-

threonine kinase

CIMP CpG metilēšanas fenotips

$C p G$ island methylator fenotype

CIN hromosomāla nestabilitāte

chromosomal instability

CISH hromogēna in situ hibridizācija

CMS molekulārais apakštips

CNV kopiju skaita variācijas

CVŠ cirkulējošās vēža šūnas

dMMR nepietiekama gēnu kḷūdu labošana

mismatch repair deficient

DT datortomogrāfija

EGFR epidermālā augšanas faktora receptors

epidermal growth factor receptor

FGFR fibroblastu augšanas faktora receptors

FISH fluorescenta in situ hibridizācija

fibroblast growth factor receptor

fluorescence in situ hybridization

FTD/TPI trifluridīns/tipiracils

Trifluridine/Tipiracil

HER2 cilvēka epidermas augšanas faktora

human epidermal growth factor

receptors 2

receptor 2

IGF2R insulīnam līdzīgā augšanas faktora 2

insulin-like growth factor 2

receptors

receptor

KMR kodolmagnētiskā rezonanse

KRAS Kirsten Ras onkogēns

Kirsten Ras oncogene homolog

KRV kolorektāls vēzis

LGR5 leicīnu saturošs G-proteīna receptors 5

leucine-rich repeat-containing $G$ protein coupled receptor 5

LPI lūzumpunktu indekss breakpoint instability index

mKRV metastātisks kolorektāls vēzis

MMR gēnu kḷūdu labošana mismatch repair

mOS vidējā kopējā izdzīvotība median overall survival

mPFS vidējā bezprogresijas izdzīvotība median progression free survival

MSI mikrosatelītu nestabilitāte

microsatelite instability 


\begin{tabular}{|c|c|c|}
\hline MSI-H & augsta mikrosatelītu nestabilitāte & microsatelite instability-high \\
\hline MSS & mikrosatelītu stabils & microsatelite stable \\
\hline mut & mutēts & mutant \\
\hline OS & kopējā izdzīvotība & overall survival \\
\hline PD1 & programmētās šūnu nāves proteīns 1 & programmed cell death protein 1 \\
\hline PDGFR & trombocītu augšanas faktora receptors & $\begin{array}{l}\text { platelet-derived growth factor } \\
\text { receptor }\end{array}$ \\
\hline PFS & bezprogresijas izdzīvotība & progression free survival \\
\hline PI3K & fosfoinozitīda 3 kināze & phosphoinositide-3-kinase \\
\hline \multirow[t]{3}{*}{ PIK3CA } & fosfatidilinozitola bifosfāta kināzes & phosphatidylinositol-4,5- \\
\hline & katalītiskā apakšvienība alfa & Bisphosphate 3-Kinase Catalytic \\
\hline & & Subunit Alpha \\
\hline pMMR & pietiekama gēnu kḷūdu labošana & mismatch repair proficient \\
\hline PTEN & fosfatāzes un tenzīna homologs (gēns) & $\begin{array}{l}\text { phosphatase And Tensin Homolog } \\
\text { (gene) }\end{array}$ \\
\hline \multirow[t]{2}{*}{ TGF $\beta$ R2 } & transformējošāa augšanas faktora $\beta$ & transforming growth factor $\beta$ \\
\hline & receptors 2 & receptor 2 \\
\hline \multirow[t]{2}{*}{ TNM } & audzējs, limfmezgli, metastāzes & Tumor, Node, Metastases (staging \\
\hline & (klasifikācija) & system) \\
\hline ТP53 & audzēja proteīns P53 & tumor protein P53 \\
\hline \multirow[t]{2}{*}{ VEGF } & vaskulārais endoteliālais augšanas & vascular endothelial growth factor \\
\hline & faktors & \\
\hline wt & neizmainīts (gēns) & wild type \\
\hline
\end{tabular}




\section{Ievads}

\section{Problēmas aktualitāte}

Kolorektālais vēzis ir viena no biežākajām onkoloğiskajām saslimšanām pasaulē, ienemot otro vietu vīriešu un trešo vietu sieviešu vidu. Kolorektālais vēzis ir otrs biežākais vēža izraisītas nāves cēlonis Eiropā. Visā pasaulē tiek atklāti aptuveni 1,8 miljoni jauni zarnu vēža gadījumi katru gadu, trešā daḷa pacientu mirst šīs diagnozes dēḷ. Jēdziens kolorektālais vēzis ietver sevī labās puses resnās zarnas vēzi (aklā zarna, augšupejošā zarna, šḳērszarna), kreisās puses resnās zarnas vēzi (lejupejošā zarna, sigmveida zarna) un taisnās zarnas vēzi $(15 \mathrm{~cm}$ resnās zarnas posms virs anālās atveres). Šis iedalījums ir balstīts uz atškirīịgo klīnisko ainu, audzēja ğenētiku, ārstēšanas taktiku un prognozi. Vērtējot ğenētiskās izmain,as, kolorektālo vēzi nevar uzskatīt par vienkāršu orgāna saslimšanu, bet gan par heterogēnu l,aundabīgo audzēju grupu, kurus saista anatomiskā lokalizācija resnajā zarnā. Metastātiska kolorektālā vēža genoma izpēte l,auj noteikt prognostiskos un predikatīvos faktorus, kurus var izmantot klīniskajā praksē. Biežāk aprakstītie ir KRAS, NRAS un BRAF alēliskie varianti, kurus izmanto medikamentozās pretvēža terapijas izvēēē, kā arī DNS reparācijas gēnu patogēnie varianti (MMR, mismatch repair), kas rada mikrosatelītu nestabilitāti un ietekmē pacienta prognozi. Gēnu sekvenēšanas un kopiju skaita variāciju analīze atklāj multiplas hromosomālās aberācijas un gēnu mutācijas, kas rodas onkoǵenēzes procesā un turpmāk nosaka audzēja agresivitāti, terapijas rezistenci un prognozi, kā arī atklāj dažādus sporādiskā un pārmantotā kolorektālā vēža onkoǵenētiskos mehānismus.

Latvijā tiek veiktas gan lokālas ārstēšanas metodes, gan metastāžu kiirurğiska rezekcija, vai medikamentoza terapija. Jāatzīmē arī būtisks fakts, ka no 2018. gada kompensējamo zāḷu sarakstam ir pievienoti vairāki mūsdien̄̄gi mērḳterapijas preparāti, kas dod iespēju mūsu pacientiem dzīvot ilgāk. Taču vislielākās grūtības ārsta praksē rodas ar iepriekš jau ārstētiem pacientiem, kuri kḷuvuši rezistenti pret san,emto k,īmijterapiju.

\section{Darba mērķis}

Pierādīt, ka klīniskos rādītājus un audzēja hromosomālās izmainas var izmantot kā prognostiskus un predikatīvus faktorus pacientiem ar metastātisku kolorektālo vēzi (mKRV).

\section{Darba uzdevumi}

1. Izvērtēt faktorus, kas ietekmē bezprogresijas (PFS) un kopējo izdzīvotību (OS). metastātiska kolorektālā vēža pacientiem, kas ārstēti P.Stradiṇa KUS Onkoloǵijas klīnikā. 
2. Izvērtēt klīnisko rādītāju - neitropēnijas un iepriekš saṇemtās ārstēšanas ilguma - ietekmi uz PFS un OS pacientiem ar refraktāru mKRV, kuri sanem trifluridīna/tipiracila (FTD/TPI) terapiju.

3. Noteikt lūzumpunktu skaita un chromothripsis ietekmi uz PFS un OS.

4. Noteikt biežākās gēnu delēcijas pacientiem ar chromothripsis.

\section{Darba hipotēze}

Metastātiska kolorektālā vēža prognozi ietekmē gan klīniski, gan molekulāri faktori. mKRV šūnās ir multipli hromosomāli pārrāvumi un delēcijas, kas rodas agrīni onkoǵenēzes procesā un ietekmē turpmāko slimības prognozi un medikamentozās ārstēšanas efektivitāti.

\section{Pētījuma zinātniskā novitāte}

Pirmo reizi Latvijā veikta metastātiska kolorektālā vēža genoma kopiju skaita variāciju analīze.

Pētījumā iegūti dati par kolorektālā vēža genoma izmain,ām, kuras varētu izmantot kā prognostiskos un ārstēšanas prediktīvos biomarkiierus.

\section{Sadarbības partneri un materiāli tehniskais nodrošinājums}

Pacientu atlase, ārstēšana, novērošana un asins paraugu savākšana veikta P.Stradiṇa KUS Onkoloğijas klīnikā.

Audu paraugi no parafīna blokiem turpmākai genoma analīzei iegūti P.Stradiṇa KUS Patoloğijas institūtā.

Vēža genoma analīze veikta Rīgas Stradiņa universitātes Onkoloǵijas institūtā.

Dala pētījuma veikta Lonsurf pirmsreğistrācijas pacientu līdzjūtības programmas ietvaros - 2 pacienti ārstēšanu saņēma P. Stradiņa KUS Onkoloğijas klīnikāa, bet 12 pacienti RAKUS Latvijas Onkoloğijas centra K,īmijterapijas un hematolog̣ijas klīnikā.

\section{Darba struktūra un autora personīgais ieguldījums}

Promocijas darba autore ir atlasījusi pacientus pētījumam, vadījusi ārstēšanu un novērošanu, kā arī reğistrējusi pacientu klīniskos un ǵenētiskos datus, veikusi to statistisko apstrādi un analīzi. Autore ir sarakstījusi šo darbu un ar to saistītās publikācijas. 


\section{Ẽtiskie aspekti}

Pētījuma veikšanai 2011. gada 6. oktobrī tika saņemta Rīgas Stradiṇa universitātes Ētikas komitejas atḷauja (1. pielikums). Pētījums veikts saskaņā ar Helsinku deklarāciju atbilstoši labas klīniskās prakses nolikumam. Visi pêtījumā iesaistītie pacienti ir parakstījuši informētās piekrišanas formu (2. pielikums) divos eksemplāros, no kuriem viens eksemplārs glabājas pie pacienta, bet otrs - P.Stradiņa KUS Onkoloğijas klīnikā.

Visi pacienti, kas piedalījās FTD/TPI pirmsreǵistrācijas pacientu atbalsta programmā, ir parakstījuši pētāmā informētās rakstveida piekrišanas formu (3. pielikums). 


\section{Literatūras apskats}

\subsection{Kolorektālā vēža epidemioloǵija}

\section{Latvijas dati}

Saslimstība ar kolorektālo vēzi Latvijā pēdējo 10 gadu laikā nav būtiski mainījusies. 2010. gadā reǵistrēti 11180 primārie onkoloğiskie pacienti, no kuriem 1108 bija diagnosticēts kolorektālais vēzis, bet 2017. gadā no 11762 primārajiem pacientiem kolorektālais vēzis diagnosticēts 1131 pacientam (SKPC, 2017).

Kolorektālā vēža saslimstība Latvijā pieaug - 1998. gadā kolorektālā vēža biežums bija 39,1, 2010. gadā - 52,8, bet 2017. gadā - 58,2 uz 100000 iedzīvotāju gadā (1.1. att.). Pēc GLOBOCAN datiem 2018. gadā tika reǵistrēti 1550 saslimšanas gadījumi (t.i. $12,7 \%$ no visiem audzējiem).

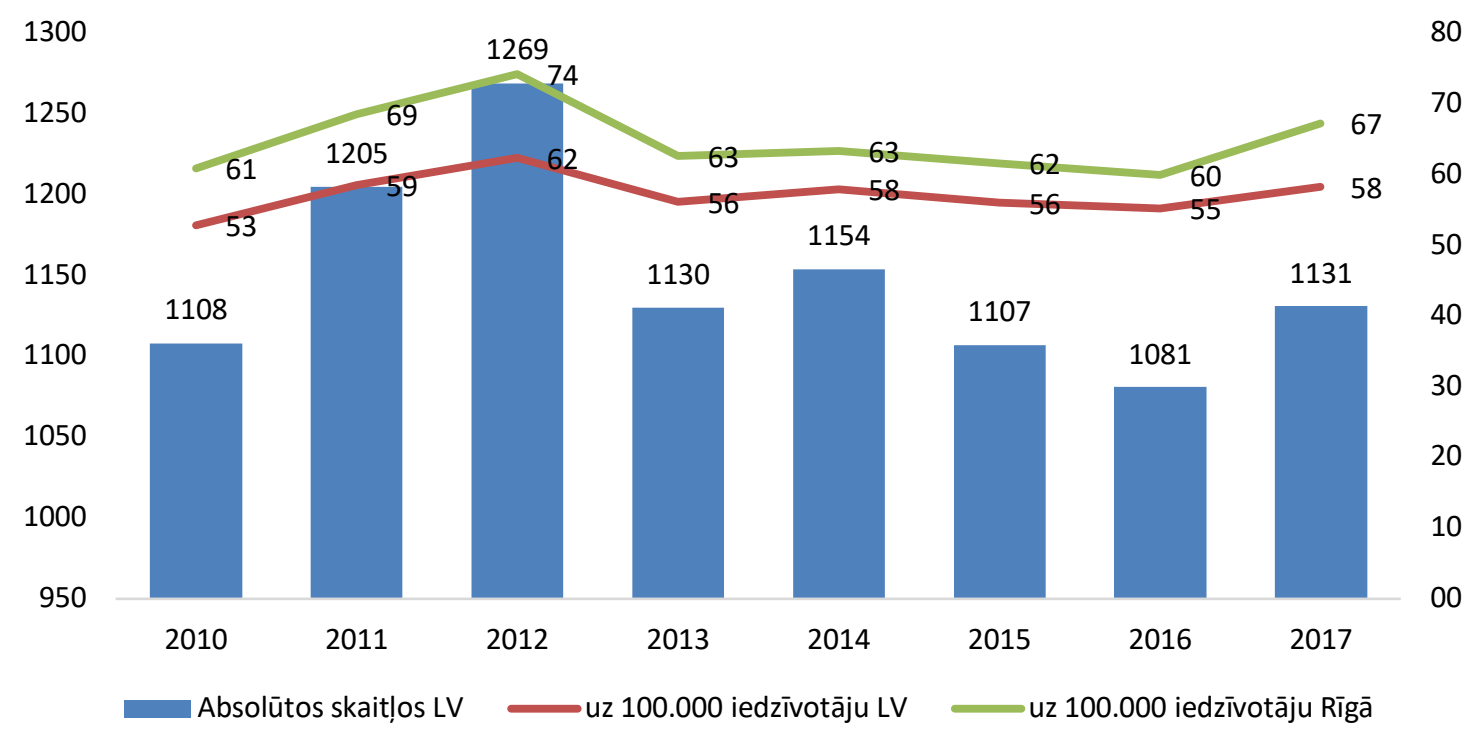

1.1. att. Saslimstība ar kolorektālo vēzi (C18-C21) Latvijā (SPKC dati)

Mirstība no kolorektālā vēža Latvijā paaugstinās - ja 1998. gadā tā bija 25,2, tad 2017. gadā - 33,2 uz 100000 iedzīvotāju gadā, kas ir izskaidrojums ar saslimstības pieaugumu (1.2. att.). 


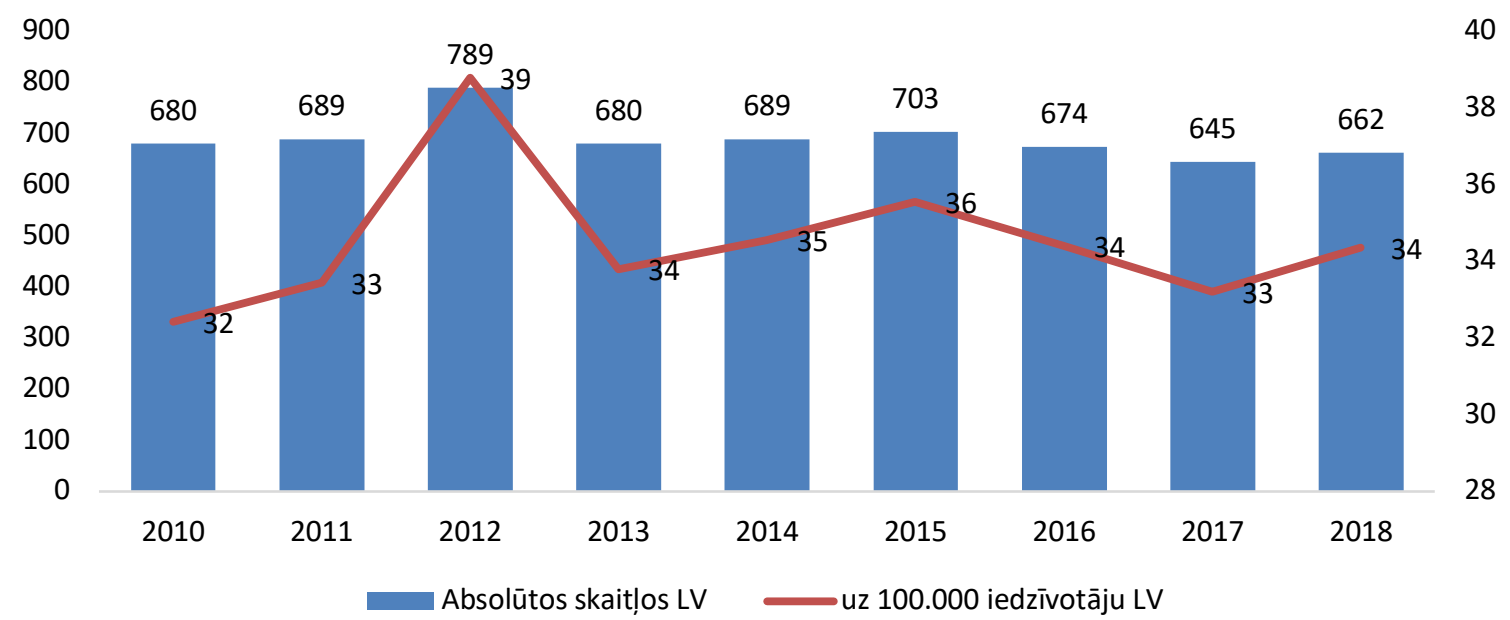

\section{2. att. Mirstība no kolorektālā vēža (C18-C21) absolūtos skaiţ̦os un uz 100000 iedzivvotāju Latvijā (SPKC dati)}

Latvijā 2010. gadā agrīni, t.i., 1. vai 2. stadijā, kolorektālo vēzi diagnosticēja tikai 35,7 \% gadījumu, bet IV stadijas pacienti bija $24,4 \%$ no kopējā skaita. Statistika pēdējos gados nav mainījusies - 2017. gadā agrīni diagnosticēts vēzis bija $32 \%$ pacientu, bet IV stadijas vēzis konstatēts $24,3 \%$ pacientu (1.3. att.).

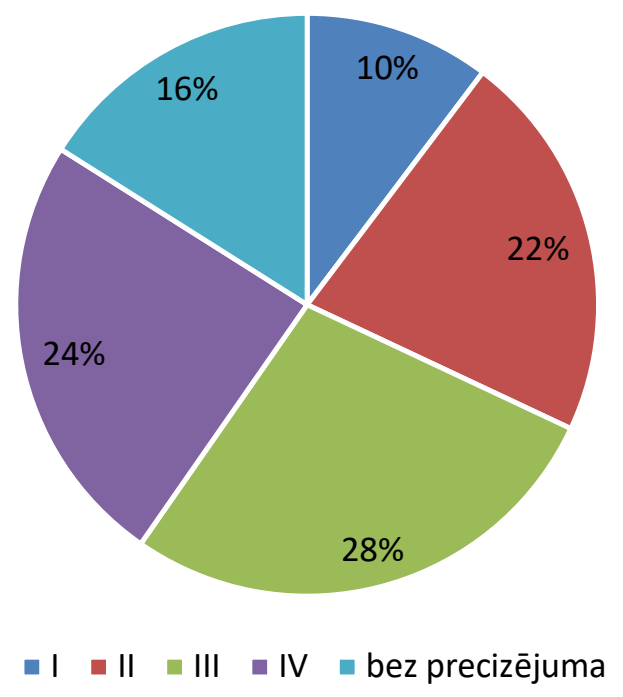

1.3. att. Kolorektālā vēža (C18-C21) stadiju sadalījums 2017. gadā Latvijāa (SPKC dati)

2017. gadā ar kolorektālo vēzi saslima 536 vīrieši (60,0 uz 100000 iedzīvotāju) un 595 sievietes (56,7 uz 100000 iedzīvotāju), bet nomira 321 vīrietis (36,0 uz 100 000) un 324 sievietes $(30,9$ uz 100 000). 82,8 \% saslimušo un 88,5 \% mirušo bija vecāki par 60 gadiem (SPKC, 2017), (1.4.att.). 


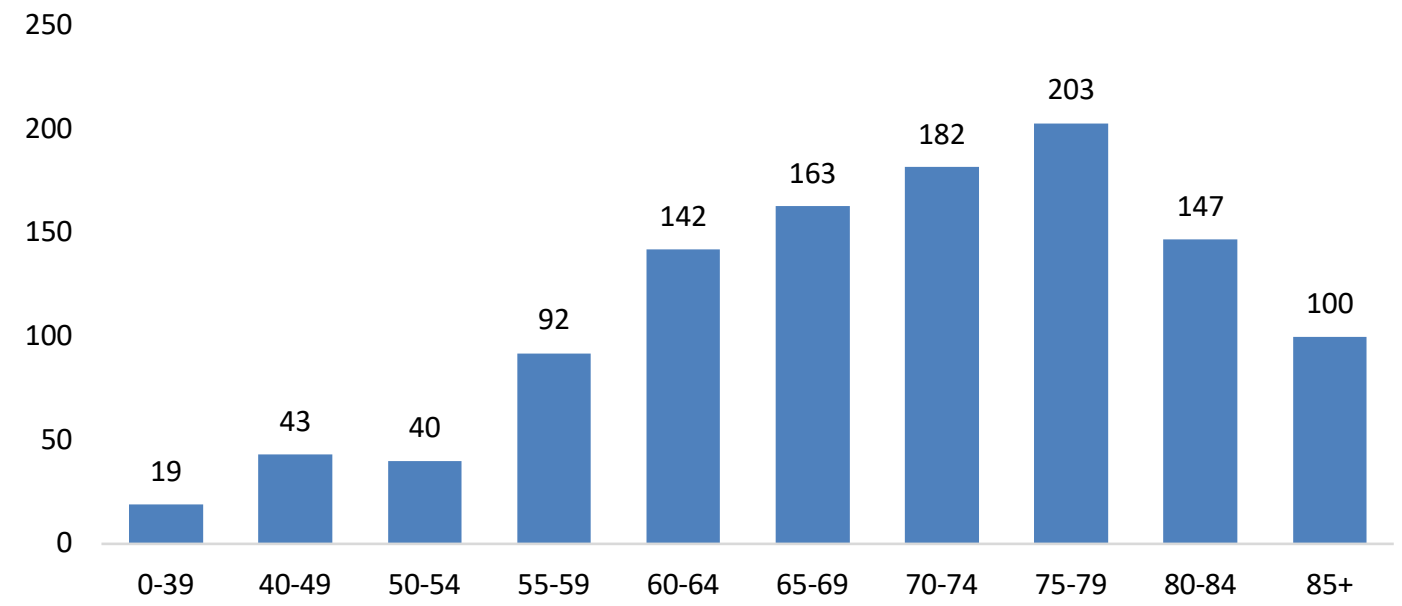

1.4. att. Saslimstība ar kolorektālo vēzi 2017. gadā dažādās vecuma grupās. 5 \% pacientu bija vecumā līdz 49 gadiem (SPKC dati)

Latvijas vēža slimnieku reǵistra dati liecina, ka kolorektālā vēža pacientu 5 gadu dzīvildze Latvijā būtiski nemainās - 38,5 \% 2002.-2007. gadā un 39 \% 2012.-2017. gadā (SPKC, 2017). To ietekmē augsts vēlīni diagnosticēto stadiju īpatsvars. Piecu gadu dzīvildze pacientiem ar IV stadijas kolorektālo vēzi Latvijā 2012.-2017.gadā ir tikai 9,7 \% pacientu (1.5. att.). Visu stadiju kolorektālā vēža pacientu pirmā gada letalitāte 2016. gadā bija 35,5\%, bet IV stadijas $-66,1 \%$.

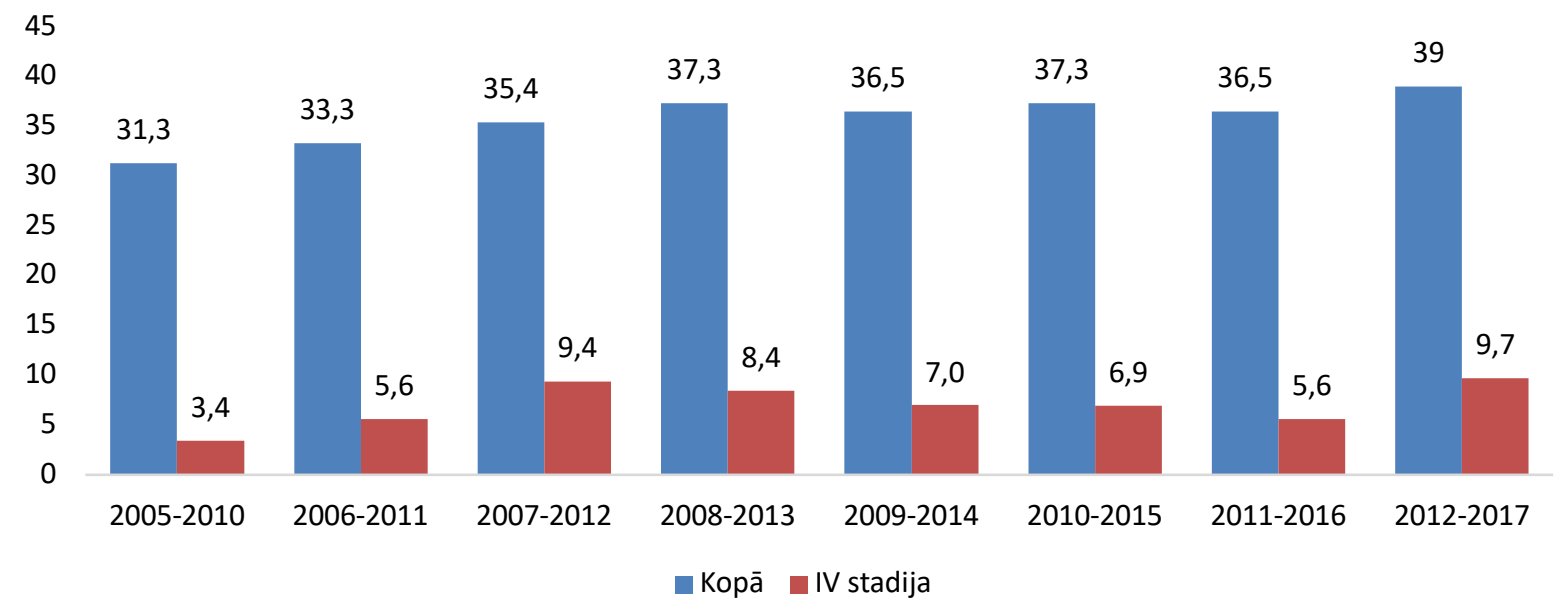

\section{5. att. 5 gadu dzīvildze visiem pacientiem kopā un IV stadijas pacientiem atsevišḳi dažādos laika periodos (SPKC dati)}

\section{Pasaules dati}

Pasaulē kolorektālā vēža saslimstība ir augsta, tas ieṇem trešo vietu aiz plaušu un krūts dziedzera vēža. Pēc GLOBOCAN datiem 2018. gadā tika diagnosticēti 1849518 jauni kolorektālā vēža gadījumi (10,2 \% no visām onkoloǵiskajām saslimšanām) un nomira 880792 
pacienti (9,2 \% no visiem vēža pacientiem). Augstākā saslimstība ir Austrālijā, Jaunzēlandē, Eiropā un Ziemeḷamerikā, bet zemākā - Āfrikā un Centrālāzijā (GLOBOCAN).

Eiropā saslimstība ar kolorektālo vēzi ien,em pirmo vietu. 2008. gadā bija 436000 jauni saslimšanas gadījumi - 13,6 \% no visiem primāri diagnosticētajiem laundabīgajiem audzējiem Eiropā; 212000 pacienti (12,3\%) mira ar šo diagnozi. 2018. gadā jau bija 487714 jauni saslimšanas gadījumi un 238752 nāves gadījumi. Tiek prognozēts, ka 2025. gadā būs 535000 jauni gadījumi un 265000 nāves gadījumi (GLOBOCAN).

ASV saslimstība ar kolorektālo vēzi 2016. gadā vīriešiem bija 42,5, bet sievietēm 33,2 uz 100000 iedzīvotāju gadā, bet mirstība bija 16,3 vīriešiem un 11,5 sievietēm uz 100000 iedzīvotāju gadā. Kopā 2016. gadā ASV reǵistrēti 141270 saslimšanas gadījumi un 52286 nāves gadījumi kolorektālā vēža dēḷ. Saslimstība ASV pēdējos 20 gados ir samazinājusies pateicoties kolorektālā vēža skrīningam. Samazinās arī mirstība, jo palielinās agrīni diagnosticēto stadiju īpatsvars, uzlabojas ārstēšana. ASV 5 gadu dz̄îildze kolorektālā vēža pacientiem ir $65 \%$. Agrīni diagnosticētu kolorektālo pacientu 5 gadu dzīvildze 1999.-2006. gadā ir 90 \%, bet IV stadijas pacientu 5 gadu dzīvildze ir vairs tikai $12 \%$ (Cancer.gov).

\subsection{Kolorektālā vēža etioloğija}

Kolorektālais vēzis ir spilgts iegūtas ǵenētiskas saslimšanas piemērs. Pakāpeniski dzīves laikā ārējo faktoru ietekmē uzkrājoties dažādām ǵenētiskām anomālijām, resnajā zarnā veidojas labdabīgi polipi, adenomas, kas pēc gadiem transformējas l,aundabīgā audzējā (Mekenkamp et al., 2010).

Metastātiska kolorektālā vēža šūnās vidēji ir 15 klīniski nozīmīgas mutācijas (driver mutations) un 61 klīniski nenozīmīga mutācija (passenger mutations), kas rada izteiktu šīs lokalizācijas audzēju ğenētisko heterogenitāti un atspoguḷo klīnisko izpausmju un slimības gaitas dažādību. Sakarā ar to, ka kolorektālais vēzis ir ğenētiski heterogēns, ir sarežğīti noteikt katras mutācijas klīnisko efektu. Turklāt mutācijas, kas agrāk tika uzskatītas par klīniski nenozīmīgām kolorektālā vēža gadījumā, ir iespējami patogēnas citu lokalizāciju audzējos (piem., IDH1 gēna mutācija nav nozīmīga kolorektālā vēža gadījumā, bet bieži sastopama glioblastomas gadījumā) (Jones et al., 2006; Wood et al., 2007).

Biežāk aprakstītās mutācijas zarnu vēža attīstībā ir APC, TP53, KRAS, PIK3CA, BRAF, NRAS, SMAD4, FBXW7 gēnos. Pētot audzēja DNS, tiek atklātas aizvien jaunas klīniski nozīmīgas mutācijas. Piemēram, mutācijas EPHA3 un EPHB6 sastopamas $20 \%$ pacientu, bet FBXW7 mutāciju atrod 14 \% pacientu ar kolorektālo vēzi (Jones et al., 2006). 
Prokadherīnu/kadherīnu saimes gēnu PCDH10, PCDH18, CDH10, CDH12 delēcija vai inaktivācija veicina kolorektālā vēža proliferāciju un metastazēšanos (Zhong et al., 2007; Zhou et al., 2017; Venkatachalam et al., 2011).

Svarīgs uzdevums ir atklāt bioloğisko signālu pārvades ceḷus un procesus, kas būtu kopīgi lielākai daḷai kolorektālo audzēju (Jones et al., 2006). Šīs zināšanas dotu iespēju atklāt jaunus medikamentus un ārstēšanas iespējas, balstoties uz onkogēnu signālu pārvades ceḷu apturēšanu.

Ir atklāti vairāki gēni, kuriem ir nozīmīga ietekme uz metastātiska vēža prognozi un terapijas efektivitāti. Biežāk literatūrā aprakstītie ir KRAS, NRAS, BRAF, PIK3CA un PTEN gēni, kuri iesaistās EGFR (epidermālā augšanas faktora receptora) signālu pārvades ceḷos, ietekmē mērkterapijas efektivitāti un pacienta izdzīvotību.

\subsection{Kolorektālā vēža onkoǵenēze}

Pastāv vairākas onkoğenēzes teorijas: 1) sporādiski multifaktoriālais onkoǵenēzes ceḷ̆š, kura pamatā ir eksogēni ārējās vides faktori un somatiskās gēnu mutācijas, 2) pārmantotais jeb Knudsona divu soḷu onkoğenēzes ceḷ̌š un 3), vismazāk pētītais, - chromothripsis onkoǵenēzes ceḷš. Uzskaitīitie vēža izcelsmes ceḷi nav pašizslēdzoši; vienam pacientam audzējs var attīstīties jebkurā veidā.

Multifaktoriāāās teorijas pamatā ir dažādu somatisko mutāciju uzkrāšanās dzīves laikā, kā rezultātā attīstās sporādisks kolorektālais vēzis. Onkoǵenēzes laikā nelabvēlīgu ārējās vides faktoru ietekmes rezultātā šūnas uzkrāj ǵenētiskas izmaiņas (mutācijas, hromosomālas aberācijas, epiǵenētiskas izmain,as) onkogēnos un audzēja nomācējgēnos, kas pieškir tām audzēja specifiskās īpašības, tostarp neierobežotu dalīšanās spēju, izbēgšanu no apoptozes, neovaskularizāciju, spēju migrēt un veidot metastāzes. Pēdējā desmitgadē aizvien plašāk tiek izmantota genoma sekvenēšana, ḷaujot identificēt gēnus, kas ir iesaistīti kanceroǵenēzē. Tos var iedalīt divās grupās: gēni, kuros ir ḷoti bieži sastopamas mutācijas, un skaitliski daudz lielāka gēnu grupa, kuru mutācijas ir reti sastopamas (Wood et al., 2007). Ir atklāts, ka kanceroğenēzē iesaistīti 54 onkogēni un 71 audzēja nomācējgēns (Vogelstein et al., 2013).

Plaušu vēža un melanomas šūnās konstatēts daudz lielāks mutāciju skaits, kas ir saistāms ar šo audzēju izcelsmi eksogēnu faktoru (smēḳēšanas, UV radiācijas) rezultātā, uzkrājoties mutācijām dzīves laikā. Arī audzējos ar DNS reparācijas gēnu mutācijām ir novērojams ḷoti liels mutāciju skaits; pie šīs grupas pieder kolorektālais vēzis. Savukārt, pediatrisko audzēju un leikozes genomā ir neliels mutāciju skaits.

Knudsona divu soḷu teorija atspogul,o onkoǵenēzi pārmantotu sindromu gadījumos, kad ir nepieciešama tikai viena sporādiska mutācija, lai attīstītos audzējs, jo vienā no divām alēlēm 
ir pārmantots patogēnais variants. Kolorektālā vēža gadījumā biežākais pārmantotais vēža veids ir Linča sindroms. Tiek pārmantots MMR gēna patogēnais variants, kas desmitiem reižu palielina mutāciju skaitu šūnā, tās uzkrājas ievērojami ātrāk un vēzis attīstās agrīnākā vecumā, salīdzinot ar sporādisku vēzi.

Pēdējos gados aizvien biežāk publikācijās parādās vēl viena vēža attīstības teorija chromothripsis jeb masīva hromosomāla fragmentācija, kas notiek vienas palaidējmutācijas gadījumā (chromothripsis, no grieḳu valodas "chromos" - hromosoma, "thripsis" - sašḳīst sīkos gabalin,os). Vienas vai vairāku hromosomu struktūra tiek izjaukta, un notiek reparācija haotiskā kārtībā, procesa rezultātā notiek audzēja nomācējgēnu delēcijas un onkogēnu amplifikācijas, neskaitāmas punktveida mutācijas gēnos, kas iesaistīti proliferācijas, apoptozes un šūnas cikla regulācijā. Visaptverošāko chromothripsis definīciju ieteica Ly un Cleveland: “chromothripsis ir katastrofāls notikums, kura laikā viena vai vairākas hromosomas saškīst un tiek reparētas nejaušā secībā, radot jaunu hromosomas derivātu ar sarežḡītu uzbūvi tikai dažu šūnas ciklu laikā” (Ly et Cleveland, 2017).

\subsubsection{Sporādiska kolorektālā vēža onkoğenēze}

Fearon un Vogelstein (1990) apraksta klasisko onkoğenēzes modeli "adenomakarcinoma". Pirmajā audzēja iniciācijas sol̄̄ eksogēna faktora iedarbības rezultātā notiek mutācija APC audzēja nomācējgēnā, veidojas polipi resnās zarnas glotādā un zarnas kriptas displastiskas izmaiṇas. APC gēna mutācijas ietekmē netiek kavēts Wnt signālu pārvades ceḷšs un rodas sekojoša $\beta$-kateīna pārprodukcija, kas veido kompleksu ar TCF (T-cell factor) un LEF (Lymphocyte enhancer factor), kas savukārt paaugstina tādu Wnt signālu pārvades ceḷa gēnu transkripciju kā LGR5, c-Myc, Axin2 un cyclin D1 (Phelps et al., 2009). Nākamajā solī, turpinoties nelabvēlīgu faktoru iedarbībai, pievienojas mutācijas KRAS, TP53, SMAD4 gēnos, kas veicina šūnu dalī̌sanos, malignu transformāciju un progresiju. Polipi ātri aug, attīstās maligns audzējs. Pacientiem ar pārmantotu ğimenes adenomatozo polipozi (FAP sindromu), $A P C$ gēna mutācija ir katrā organisma šūnā, bet audzējs attīstās galvenokārt tikai resnajā zarnā. Šis novērojums liecina par to, ka APC gēna mutācija ir nozīmīga tikai specifiskā, orgānam raksturīgā mikrovidē. Vairumam kolorektālā vēža pacientu ir notikusi APC inaktivācija, bet tikai retos gadījumos $A P C$ nav izmainīts, taču ir novērojama mutācija Axin1, Axin2 un CTNNB1 gēnos, kas arī ietekmē $\beta$-katenīna atkarīgo Wnt signālu pārvades ceḷu. Mutāciju izpēte labdabīgās, izmainītās un malignās šūnās ir devusi iespēju noteikt laika nogriezni, kas atdala audzēja attīstības stadijas. Tiek lēsts, ka ir nepieciešami 17 gadi, lai labdabīga resnās zarnas adenoma attīstītos par karcinomu, bet tikai 2 gadi, lai attīstîtos invazīvs resnās zarnas vēzis. 
Turklāt, lai vēža šūna iegūtu spēju migrēt un veidot metastāzes, ir nepieciešamas tikai dažas mutācijas (Nikolaev et al., 2012; Hashimoto et al., 2017).

Onkoǵenēzes modelis "adenoma-karcinoma" norāda uz pieaugošu genoma nestabilitāti mutāciju uzkrāšanās rezultātā. Turpmākie pētījumi parāda, ka resnās zarnas vēža gadījumā ir divi genoma nestabilitātes veidi ar atškirīgām mutācijām - hromosomāla nestabilitāte un mikrosatelītu nestabilitāte. Hromosomālās nestabilitātes jēdziens ietver sevī dažādas strukturālas hromosomu izmaiņas, kas tiek novērotas $70 \%$ kolorektālā vēža gadījumu. Tā ir raksturīga tieši "adenoma-karcinoma" modelim. Pretstatā hromosomālai nestabilitātei, mikrosatelītu nestabilitāti novēro $15 \%$ kolorektālo vēžu gadījumu un to raksturo mutācijas DNS reparācijas gēnos un mikrosatelītu garuma izmaiņas. Mikrosatelītu nestabilitāti rada ne tikai DNS reparācijas gēnu mutācijas, bet arī $B A X$, insulīnam līdzīgā augšanas faktora receptora 2 (IGF2R) un augšanas faktora receptora 2 (TGFßR2) gēnu mutācijas. Mikrosatelītu nestabilitāte kolorektālā vēža šūnās ir saistīta ar labāku prognozi, salīdzinot ar hromosomālo nestabilitāti (Walther et al., 2009).

Tiek uzskatīts, ka "adenoma-karcinoma" onkoǵenēzes soḷi notiek arī vēža cilmšūnās. Kolorektālā vēža gadījumā par tādām var uzskatīt resnās zarnas epitēlija cilmšūnas, jo tām ir garākais dzīves ilgums un iespēja uzkrāt ǵenētiskās mutācijas un epiǵenētiskās izmaiṇas. Pēc tam, kad epitēlija cilmšūnā ir notikušas ğenētiskas izmaiņas, tā turpina dalīties, nesot mutācijas un uzkrājot jaunas (Barker et al., 2009). Zarnas gḷotādas adenoma jeb polips satur lielu daudzumu izmainītu zarnas epitēlija cilmšūnu. Zarnas cilmšūnas (LGR5 ekspresējošās šūnas) izvietojas ne tikai kriptās pie bazālās membrānas, bet gan visā adenomatozā polipa masā, turpretī hiperplastiskajos un zobainajos polipos LGR5 pozitīvās šūnas ir lokalizētas pie bazālās membrānas (Barker et al., 2015).

Sporādiska kolorektālā vēža onkoǵenēzē tiek izdalīts atseviški zobainā polipa attīstības ceḷ̌s (angl. serrated pathway), (1.6. att.). Zobainie polipi, agrāk saukti par hiperplastiskajiem polipiem, ir heterogēna neoplāziju grupa, kuras vienojošā iezīme ir zāğa zobu (angl. saw tooth) morfoloğija, bet atškirīgs ir to ļaundabīgais potenciāls un molekulārais profils. Šajā grupā ietilpst gan hiperplastiskie polipi, gan zobainie polipi, pie kuriem pieskaitāmi arī plakanās zobainās adenomas (angl. sessile serrated adenoma). Zobainā polipa onkoǵenētiskā transformācija sākas ar onkogēna BRAF aktivējošu mutāciju, kas aktivizē MAPK signālu pārvades ceḷu. BRAF gēna aktivācija veicina zarnas epitēlija cilmšūnu novecošanos un diferenciāciju, bet, pievienojoties $C D X 2$ vai $S M A D 4$ gēna inaktivējošai mutācijai, tiek atjaunota zarnas cilmšūnu aktivitāte un veicināta transformācija (Sakamoto et al., 2017; Tong et al., 2017). Gḷotādā vēro lēni augošus hiperplastiskus polipus, kas lēni progresē līdz displastiskām 
izmaiņām. Lai notiktu turpmāka zobainā polipa transformācija l,aundabīgā audzējā, nepieciešama mutācija TP53 un TP16 audzēja nomācējgēnos (Rad et al., 2013).

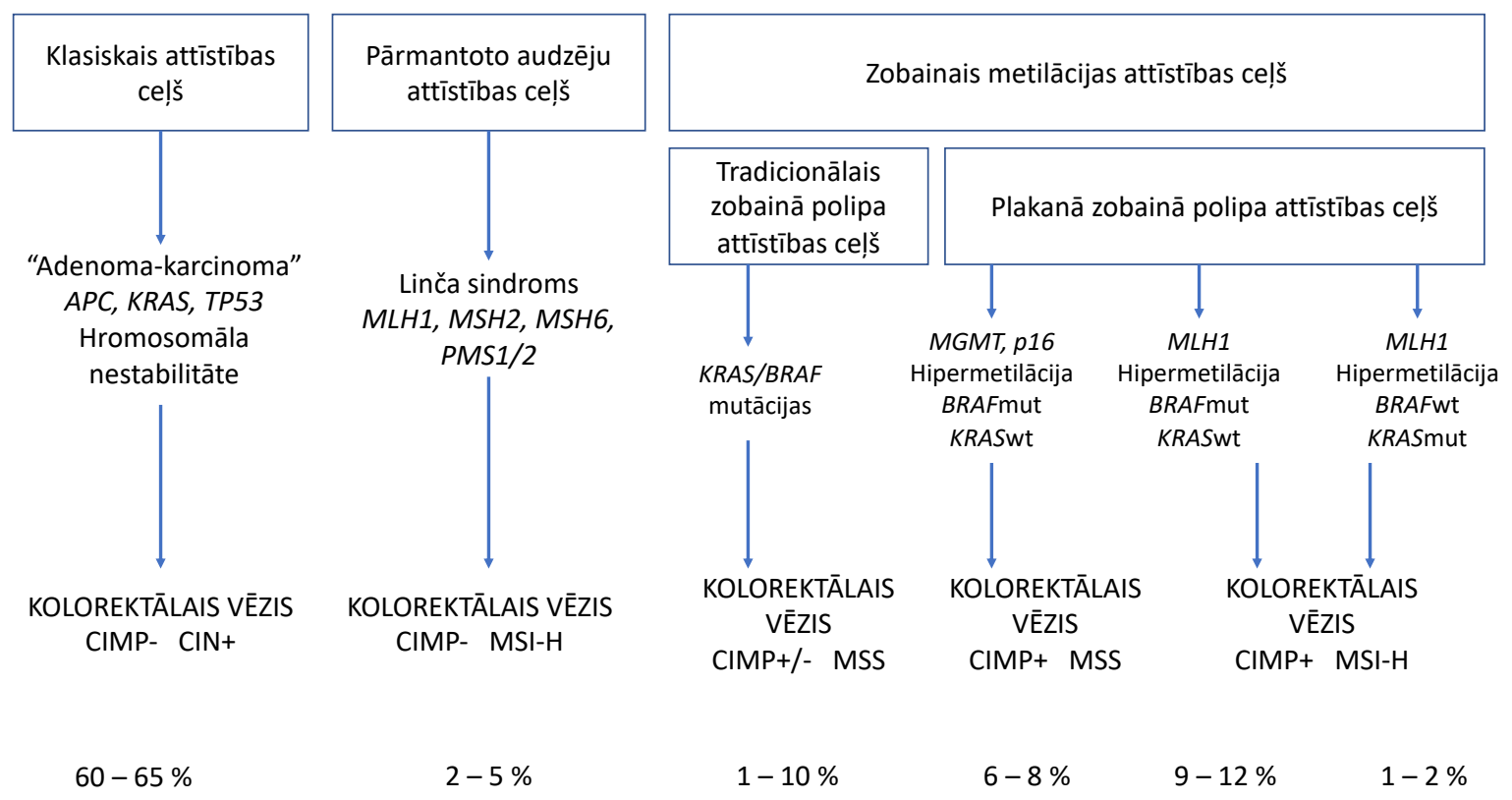

\section{6.att. Onkog̀enēzes ceḷi}

Klasisko "adenoma-karcinoma" ceḷu raksturo $A P C$ mutācija, hromosomāla nestabilitāte, MSS. Audzējam, kas attīstās pārmantoto audzēju attīstības ceḷā, raksturīga mikrosatelītu nestabilitāte (MSI-

H).Tradicionālajam zobainā polipa ceļam ir raksturīgas $K R A S$ un $B R A F$ mutācijas, mikrosatelìtu stabilitāte (MSS) un variabls CpG metilēšanas fenotips (CIMP). Plakanā zobainā polipa ceļam ir iespējami trīs atšķirīgi vēža attīstības veidi: 1) MSS, $\mathrm{CIMP}^{+}, B R A F$ mut un $K R A S \mathrm{wt}$; 2) MLH1 promotera hipermetilācija, $B R A F$ mut, KRASwt un 3) MLH1 promotera hipermetilācija, $B R A F \mathrm{wt}, K R A S m u t$ (Tesla et al., 2018)

\subsubsection{Chromothripsis}

Stephens et al. 2011. gadā pirmo reizi aprakstīja chromothripsis fenomenu, kas tika novērots 2-3\% l,aundabīgu audzēju. Chromothripsis prevalence, ietekme uz vēža attīstību un prognozi nav pietiekami pētīta. Chromothripsis biežums dažādos audzējos ir būtiski atškirīgs 1,3 \% multiplās mielomas gadījumos (Magrangeas et al., 2011), 6,6 \% akūtas mieloleikozes gadījumos (Fontana et al., 2018), 33 \% osteosarkomas gadījumos (Stephens et al., 2011) un $60 \%$ invazīva urīnpūšla vēža gadījumā (Morrison et al., 2014).

Chromothripsis būtiski pasliktina prognozi krūts vēža, multiplās mielomas un medulloblastomas pacientiem, bet tā nozīme kolorektālā vēža pacientiem nav skaidra. Chromothripsis fenomenu raksturo multipli lūzumpunkti (angl. brake points) hromosomās. 2015. gadā Van den Broek et al. publicēja lūzumpunktu nozīmi metastātiska kolorektālā vēža onkoǵenēzē. Tika identificēti 1605 hromosomāli lūzumpunkti, no kuriem 748 lūzumpunkti atkārtojās dažādos audzēja paraugos. Neviens no individuālajiem lūzumpunktiem atsevišḳi 
neietekmēja izdzīvotību, bet autors izdalīja vairākus kolorektālā vēža tipus, kuriem bija kopīgas vairākas mutācijas.

Krūts vēzim raksturīgs mazāks lūzumpunktu skaits jeb lūzumpunktu indekss (LPI) visvairāk lūzumpunktu ir 17. hromosomā, bet vismazāk - 4. hromosomā (Przybytkowski et al., 2014). Chromothripsis un augsts lūzumpunktu indekss raksturo genoma nestabilitāti.

Turpmāko astoṇu gadu laikā pēc pirmās publikācijas par chromothripsis ir aprakstītas "hromopleksija" un "hromoanasintēze:, bet visus trīs jēdzienus apvieno termins "hromoanaǵenēze" (no griek,u val. chromos - hromosoma, anagenesis - atdzimšana), kas norāda uz strukturālu hromosomu pārbūvi: hromosomas fragmentācija ar sekojošu pārbūvi (Holland et al., 2012). Chromothripsis gadījumā, atšḳirībā no hromopleksijas un hromoanasintēzes, hromosomā ir ievērojami vairāk pārrāvumu (lūzumpunktu) un hromosomas fragmenti tiek savienoti nepareizā secībā un virzienā (1.7. att.). Šobrīd nav definēts, cik lūzumpunktiem ir jābūt hromosomā, lai diagnosticētu chromothripsis fenomenu: atškirīgos pētījumos tiek norādīts dažāds lūzumpunktu skaits (10-50-100) vienā hromosomā, bet tā nav izškirošā pazīme (Holland et al., 2012).
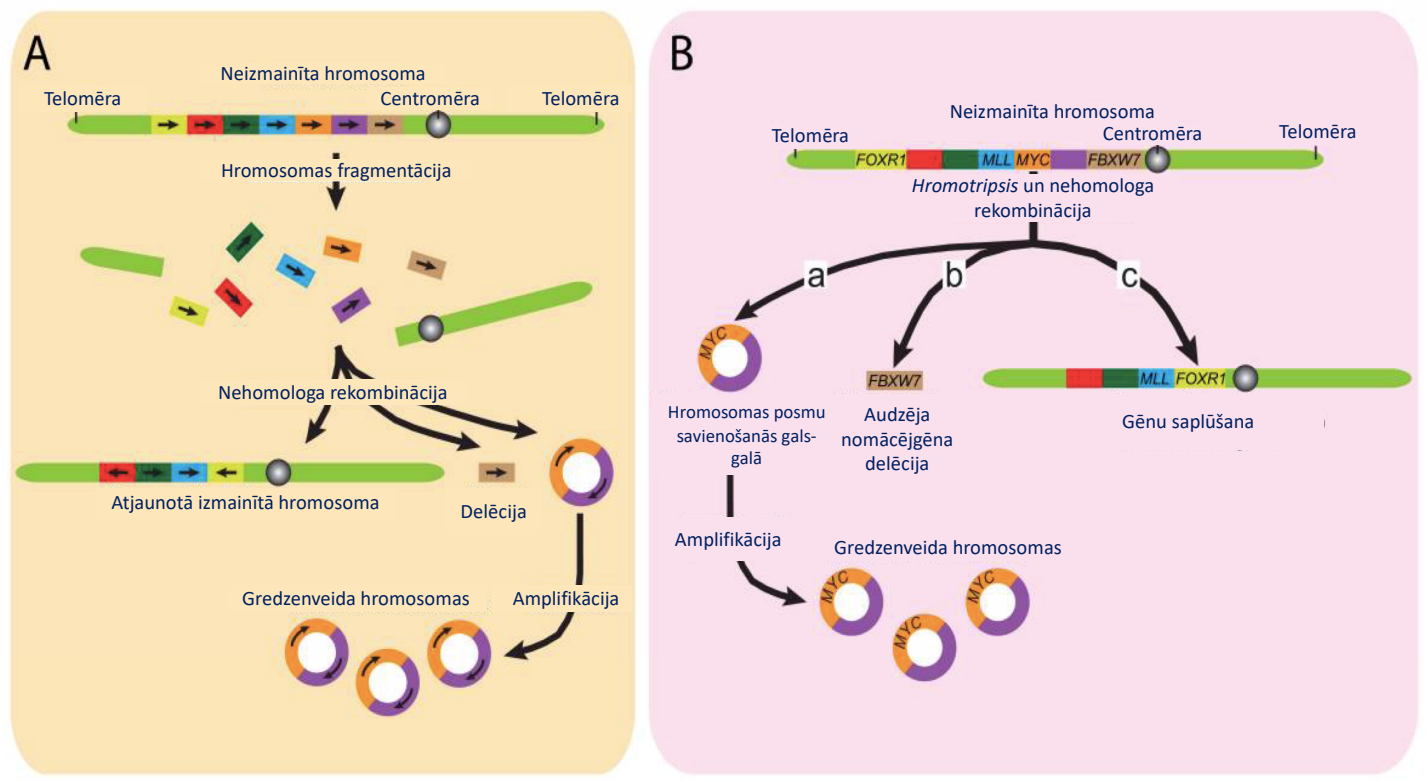

\section{7. att. Chromothripsis mehānisms}

Chromothripsis ir vienas vai vairāku hromosomu sadalīšanās un vienlaicīga nehomologā rekombinācija (angl. non-homologous end joining, NHEJ). Nepareiza hromosomas gabalinu savienošanās rada hromoanaǵenēzi: izveidojas jauna hromosoma ar augstu mutāciju blīvumu, kura vienlaicīgi var gan saturēt vairākas gēnu kopijas un sapludinātus gēnus, gan pazaudēt hromosomas reǵionus. Atrautie DNS gabaliṇi var savienoties "gals-galā" un veidot gredzenveida (angl. double minute) hromosomas, kas bieži satur onkogēnu amplifikācijas. Rezultātā vienlaicīgi rodas onkogēnu kopiju skaita pieaugums, audzēja nomācējgēnu delēcijas, gēnu saplūšana (angl. fusion genes), translokācijas un inversijas (Holland et al., 2012) 
Chromothripsis rašanās mehānismi ir (Koltsova et al., 2019):

1) mikrokodolu veidošanās nepilnvērtīgas mitozes rezultātā; hromosomas un to acentriski fragmenti var tikt ietverti kodolapvalkā ārpus šūnas kodola. Mikrokodoliem ir raksturīga augsta hromatīna kondensācija un hromosomālie pārrāvumi, kā arī riņksveida hromosomu veidošanās;

2) apoptozes pārtraukšana, kas ir saistīta ar TP53 mutāciju. Gan pacientiem ar Li-Fraumeni sindroma (pārmantota TP53 mutācija) asociētu medulloblastomu, gan pacientiem ar hronisku un akūtu limfoleikozi ar TP53 mutāciju, ir konstatēts vienlaicīgs chromothripsis fenomens;

3) telomēru saīsināšanās, saplūšana un dicentriskas hromosomas veidošanās;

4) eksogēnu faktoru izraisīta hromosomas pulverizācija. Hromosomas pulverizācija ir ļoti izteiktas hromosomas sadalīšanās piemērs. Multiplus DNS dubultpārrāvumus var izraisīt tādi ārējie faktori, kā medikamenti, jonizējošais starojums, oksidatīvais stress vai vīrusu infekcija;

5) epiǵenētiskās izmaiņas - DNS metilēšanas traucējumi.

Šie ir iespējamie chromothripsis mehānismi un ir nepieciešami turpmākie pētījumi, lai apstiprinātu chromothripsis izcelsmi un nozīmi onkoǵenēzē. Ir radīta ChromothripsisDB datubāze, kurā līdz 2018. gada martam bija ievadīti dati par chromothripsis fenomenu 500 vēža paraugos no 46 dažādiem audzēju veidiem, t.sk. 13 kolorektālā vēža paraugiem (1.8. att.).

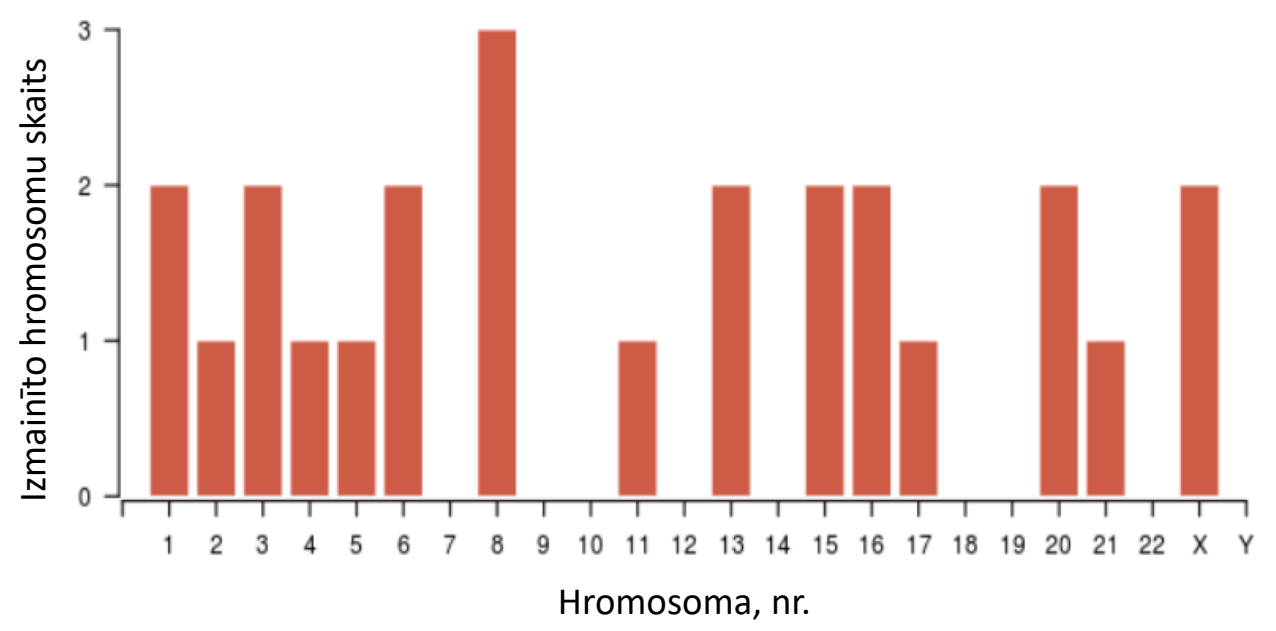

1.8. att. Chromothripsis skartās hromosomas 13 pacientiem ar kolorektālo vēzi Attēls iegūts no ChromothripsisDB datubāzes (Cai et al., 2018)

Kolorektālā vēža heterogenitātes izpēte ir devusi izpratni par molekulārajiem un celulārajiem procesiem primārajā audzējā, metastāzēs un par onkoǵenēzi. 
Viens no nesen aprakstītajiem onkoğenēzes ceḷiem ir "big bang” jeb lielā sprādziena teorija. Šajā hipotētiskajā modelī pēc sākotnējās mutācijas notiek klonāla ekspansija, - audzēju veido savā starpā saistīti apakškloni. Lielā sprādziena teorija balstās uz vairākiem novērojumiem: 1) intratumorālā heterogenitāte ir kolorektālā vēža galvenā pazīme, tā attīstās agrīni onkoǵenēzes procesā, progresē audzējam augot un izplatoties, rezultātā audzējam ir raksturīga sazarota filoǵenēze (branched phylogenies); 2) lielākā ǵenētisko izmain,u daḷa notiek agrīni; 3) agres̄̄vo subklonu ir salīdzinoši maz primārajā audzējā, bet, audzējam progresējot un pielietojot medikamentozu terapiju, tie kḷust dominējoši (Sottoriva et al., 2017).

\subsubsection{Pārmantota kolorektālā vēža onkoǵenēze}

Pārmantoto kolorektālo vēžu veidu un iesaistīto ǵenētisko mutāciju izpēte l̦auj identificēt jaunus onkoǵenēzes mehānismus. Yurgelund et al. publicētajā pētījumā tika aprakstīti 25 gēni, kas bija asociēti ar pārmantoto kolorektālo vēzi. Tikai nelielai daļai pacientu atklātas viena vai vairākas mutācijas - 3,1 \% Linča sindroms, 2,2 \% mutācijas augstas penetrances gēnos (APC, MUTYH), (Yurgelun et al., 2017). Lielākajai daļai pacientu ar pozitīvu kolorektālā vēža ğimenes anamnēzi neatrod raksturīgās gēnu izmaiņas, bet diagnoze tiek apstiprināta ar Amsterdamas kritēriju palīdzību.

Ir zināmi vairāki pārmantotā kolorektālā vēža sindromi:

1. Linča sindroms jeb pārmantots nepolipozs resnās zarnas vēzis - mutācija DNS reparācijas gēnos (MLH1, MSH2, MSH6, PMS2, EPCAM), kas rada augstu mikrosatelītu nestabilitāti. Kolorektālā vēža saslimšanas risks ir $50-80 \%$, biežums 2-4\%, kas ir visbiežākais pārmantotā resnās zarnas vēža veids. Pacientiem ir bieži sastopama endometrija un urīnceļu audzēji (Jasperson et al., 2010; Bērziņa et al., 2012).

2. Ģimenes adenomatozā polipoze - mutācija $A P C$ gēnā. Resnajā zarnā veidojas $>1000$ polipi, agrīni attīstās kolorektāls vēzis. Kolorektālā vēža saslimšanas risks ir $100 \%$, biežums $<1 \%$ (Daneberga et al., 2019).

3. MUTYH-asociētā polipoze (MAP) - mutācija $M U T Y H$ gēnā, kas ietekmē nukleotīdu izgriešanas DNS reparācijas sistēmu, recesīvs pārmantošanas veids. Klīniski novēro multiplus polipus. Kolorektālā vēža risks ir 20 reizes augstāks nekā populācijā, sasniedzot 43-100\% slimības penetranci 60 gadu vecumā, biežums $<1 \%$ (Nielsen et al., 2011). 
4. PAPP sindroms (angl. Proofreading polymerase-associated polyposis) - mutācija POLD1 un POLE gēnos. Ietekmēta DNS labošana replikācijas laikā. Klīniski novēro $<100$ polipiem, agrīns saslimšanas vecums un bieži tiek novēroti arī citi l̦aundabīgi audzēji. POLE mutāciju asociētajam kolorektālajam vēzim ir raksturīgs MMR deficīts un paaugstināta CD8 limfocītu infiltrācija. Kolorektālā vēža saslimšanas risks ir augsts, biežums < 1 \% (Palles et al., 2013; Patzold et al., 2017).

5. NTHL1 asociētā adenomatozā polipoze - recesīvs pārmantošanas veids, mutācija DNS glikozilāzes gēnā NTHL1, traucēta bāzu ekscīzija (DNS reparācijas mehānisms). Saslimšanas risks mutāciju nesējiem ir līdzvērtīgs citiem polipozes sindromiem (ğimenes adenomatozā polipoze, $M U T Y H$-asociētā polipoze), biežums $<1 \%$ (Weren et al., 2015).

6. Ģimenes juven̄ilā polipoze - mutācija SMAD4, BMPRl gēnos, kas ietekmē TGF- $\beta$ signālu pārvadi. Klīniski novēro multiplus polipus kungǵī un resnajā zarnā, kā arī hemorāg̣iskas teleangiektāzijas. Saslimšanas risks ar kolorektālo vēzi ir 39-68 \%, mutācijas biežums $<1 \%$.

7. Peitsa-Džegera (Peutz-Jeghers) sindroms - mutācija STK11 gēnā, kas ir iesaistīts vairākos signālu pārvades ceḷos. Klīniski novēro hiperpigmentācijas ādā un gḷotādās, intestinālus hamartomatozus polipus. Saslimšanas risks ar kolorektālo vēzi dz̄ives laikā ir $39-57 \%$, biežums $<1 \%$.

8. Koudena (angl. Cowden) sindroms vai PTEN hamartomas-tumora sindroms samazināta PTEN proteīna ekspresija, kas ietekmē AKT signālu pārvadi un rada hromosomālo nestabilitāti. Klīniski novēro dažus polipus resnajā zarnā, multiplus hamartomatozus polipus un lipomas. Saslimšanas risks ar kolorektālo vēzi ir 9-16 \%, biežums $<1 \%$.

9. CHEK2 - mutācija CHEK2 gēnā, kas ietekmē ciklīnatkarīgās kināzes funkciju. CHEK2 1100delC ir sastopama 4-5 \% pārmantotu nepolipozo kolorektālo audzēju gadījumos, asociēta ar audzējiem citos orgānos. Biežums < 1 \% (Kaufman et al., 2009).

10. Hiperplastiskās polipozes sindroms - mutācija $R N F 43$ gēnā, izmainīts WNT/ $\beta$-kateīna signālu pārvades ceḷš. Klīniski novēro nelielu skaitu zobainu polipu proksimālajā resnās zarnas daḷā un sigmveida zarnā. Saslimšanas risks ar kolorektālo vēzi ir 50 \%, biežums $<1 \%$. 


\subsection{Kolorektālā vēža klasifikācijas veidi}

Kolorektālais vēzis var tikt klasificēts atkarībā no tā anatomiskās lokalizācijas, histologiskā tipa, izplatības plašuma, izcelsmes veida, genoma un epiǵenētiskajām atšķirībām. Jebkura klasifikācija radīta, lai pacientiem ar KRV piemērotu atšķirīgus ārstēšanas veidus, prognozētu terapijas efektivitāti un izdzīvotību, atbilstoši konstatētajam vēža apakštipam vai stadijai.

Labās puses resnās zarnas embrioloǵiskā izcelsme un asins apgāde atšķiras no kreisās puses resnās zarnas. A. mesenterica sup. apasiņo tievās zarnas un resno zarnu līdz šķērszarnas vidusdaļai (angl. midgut), bet a. mesenterica inf. - no šķērszarnas vidusdaļas līdz taisnajai zarnai (angl. hidgut). Labās puses audzēji attīstās aklajā zarnā, augšupejošajā zarnā un šķērszarnā. Kreisās puses audzēji attīstās lejupejošajā zarnā, S-veida zarnā un taisnajā zarnā. Atkarībā no vēža anatomiskās lokalizācijas, atškiras mikrobioms, klīniskā aina, metastazēšanās vietas, molekulārais profils, prognoze un atbildes reakcija uz saņemto medikamentozo terapiju (Stintzing et al., 2017). Labās puses audzēji ilgstoši ir asimptomātiski, tiem raksturīgās izpausmes ir anēmija, peritoneālas un aknu metastāzes, bet kreisās puses audzējiem raksturīga zarnu obstrukcija, biežāk novērojamas plaušu metastāzes, bez tam šiem audzējiem ir labāka prognoze. Molekulārie pētījumi apstiprina labās un kreisās puses kolorektālā vēža atškirīigo etiologiju, patoǵenēzi un prognozi. Augsta mikrosatelītu nestabilitāte (MSI-H) un BRAFmut incidence lineāri samazinās virzienā no augšupejošās resnās zarnas uz taisno zarnu, bet $A P C$ un TP53 mutācijas - pretējā virzienā. KRAS mutācijas biežums dažādās zarnas daḷās būtiski neatšķiras (Yamauci et al., 2012; Salem et al., 2017). Atkarībā no primārā audzēja lokalizācijas vietas, atšķkiras arī kolorektālā vēža molekulārie tipi (CMS): > 75 \% CMS1 tipa audzēju lokalizācija ir labajā zarnas pusē, bet $5 \%$ taisnajā zarnā, turpretī > 90 \% CMS4 tipa audzēju lokalizācijas vieta ir kreisās puses resnā zarna un taisnā zarna (1.1. tab.), (Lee et al., 2017).

Zarnu vēzi var klasificēt pēc histoloğiskā tipa - visbiežākais veids ir adenokarcinoma (zemas, vidējas un augstas diferenciācijas pakāpes), retāk sastopami veidi ir mucinoza adenokarcinoma, adenoskvamozs vēzis, gredzenšūnu un medullāra karcinoma. Audzēja histologiskais veids korelē ar prognozi - medullārais vēzis ir asociēts ar labāku prognozi, bet vissliktākā prognoze ir gredzenšūnu vēža gadījumā.

Pēdējās dekādēs, attīstoties molekulārajai bioloğijai un vēža ǵenētikai, palielinās izpratne par kolorektālā vēža molekulārajiem tipiem, patoǵenēzi un onkoǵenēzi. No ǵenētiskā skatpunkta, kolorektālais vēzis ir heterogēna malignu saslimšanu grupa, kuras vieno atrašanās vieta - resnās zarnas epitēlijs. 
Atškirīgajos kolorektālā vēža attīstības ceḷos rodas dažādi audzēju apakštipi, kurus nosaka pēc galvenajām molekulārajām izmain̄ām un mutācijām, ieskaitot hromosomālo nestabilitāti (CIN), mikrosatelītu nestabilitāti (MSI), CpG metilēšanas fenotipu (CIMP), BRAF mutācijas un KRAS mutācijas. Phipps kolorektālo vēzi iedala piecos apakštipos, pamatojoties uz šo audzēja markieru kombinācijām (Phipps et al., 2015):

1. tipa kolorektālais vēzis - MSI-H, CIMP ${ }^{+}, B R A F$ mut, $K R A S w t$;

2. tipa kolorektālais vēzis - MSS vai MSI-L, $\mathrm{CIMP}^{+}, B R A F$ mut, $K R A S w t$;

3. tipa kolorektālais vēzis - MSS vai MSI-L, CIMP-, BRAFwt, KRASmut;

4. tipa kolorektālais vēzis - MSS vai MSI-L, CIMP-' $B R A F \mathrm{wt}, K R A S \mathrm{wt}$;

5. tipa kolorektālais vēzis - MSI-H, CIMP-, $B R A F \mathrm{wt}, K R A S \mathrm{wt}$;

Sinicrope ir aprakstījis līdzīgu molekulārās klasifikācijas veidu III stadijas KRV pacientiem, pamatojoties uz MRR statusu, KRAS un BRAF mutāciju esamību - trīs apakštipi ir pMRR: BRAFmut (7\%), KRASmut (35\%) vai mutācija vienā no šiem gēniem (49\%), bet divi apakštipi ir dMRR: sporādiskais apakštips ar BRAF mutāciju un/vai $M L H 1$ hipermetilāciju un pārmantotais apakštips bez BRAF mutācijas vai $M L H 1$ hipermetilācijas (Sinicrope et al., 2015).

Ap $60 \%$ kolorektālo audzēju ir ar CIN, MSS, CIMP fenotipu. Ap $20 \%$ kolorektālo vēžu ir ar zemu CIMP, KRASmut, MGMT metilēti un MSS/MSI-L. 12 \% sastop CIMP+, $B R A F$ mut un MSI-H. $8 \%$ gadījumu novēro CIMP+, BRAFmut, hromosomālo stabilitāti un mikrosatelītu stabilitāti. Visretāk (3\%) sastop CIMP, BRAFwt, MSI-H un hromosomālo stabilitāti. Atkarībā no molekulārā veida, audzējam ir atškirīga prognoze - negatīvie prognostiskie markieri ir BRAFmut un CIMP+ (Jass et al., 2007; Zlobec et al., 2012).

Lielākā daḷa kolorektālo audzēju attīstās iepriekš aprakstītajā "adenoma-karcinoma" ceḷā no neizmainītas zarnu gḷotādas līdz adenomai un karcinomai. Šajā ceḷā notiek audzēja nomācējgēnu inhibēšana un onkogēnu aktivācija. Šo mutāciju uzkrāšanās rezultātā veidojas kolorektālais vēzis ar MSS, CIMP, CIN, KRASwt un BRAFwt un APC mutācijām. Šiem audzējiem parasti ir labāka prognoze par $B R A F$ mut kolorektālo vēzi, bet sliktāka prognoze par MSI-H kolorektālo vēzi (Phipps et al., 2015; Sinicrope et al., 2015).

Aptuveni 20-30 \% kolorektālo vēžu attīstās zobainā polipa onkoǵenēzes ceḷā; šie audzēji parasti ir BRAFmut vai KRASmut un tos raksturo CIMP+. Kolorektālais vēzis, kuram ir $B R A F$ mut, KRASmut, CIMP+ un MSS, ir saistīts ar ḷoti sliktu prognozi. Jāatzīmē, ka pacientiem ar zobainā polipa onkoğenēzes ceḷā attīstījušos vēzi un ar BRAFmut, CIMP+ un MSI-H apakštipu ir salīdzinoši labāka prognoze nekā tiem, kuriem ir tradicionālā "adenomakarcinoma" ceḷā attīstījies audzējs. Tas norāda uz to, ka pat pacientiem ar zobainā polipa transformācijas fenotipu ir iespējama atšķirīga prognoze atkarībā no mikrosatelītu stāvokḷa (Phipps et al., 2015; Sinicrope et al., 2015). Šie novērojumi liecina, ka ir nepieciešama 
kolorektālā vēža klasifikācija atbilstoši molekulārajiem marķieriem arī ikdienas klīniskajā praksē, izvēloties optimālāko ārstēšanas veidu.

Ap 6 \% kolorektālo audzēju attīstās pārmantotā ceḷā - 3,1 \% Linča sindroms, 2,2 \% ǵimenes adenomatozā polipoze un $1 \%$ - pārējie pārmantotā vēža sindromi (Yurgeilun et al., 2017). Linča sindromu izraisa mutācijas DNS labotājgēnos (biežāk MSH2 vai $M L H 1$ gēnos), bet ğimenes adenomatozo polipozi - mutācija $A P C$ audzēja nomācējgēnā. Ar Linča sindromu saistītais kolorektālais vēzis ir multifokāls, ar MSI-H raksturīgo histologijas veidu. Atšksirībā no sporādiska MSI-H audzēja, Linča sindromam nav raksturīga $B R A F$ mut un CIMP+. $95 \%$ audzēju ar defektu DNS labotājgēnos ir raksturīgs MSI-H fenotips, bet $K R A S$ mutācija novērota 40 \% pacientu (Pinheiro et al., 2015).

Kolorektālā vēža klasifikācijai klīniskajā praksē visbiežāk izmanto AJCC (angl. American Joint Committee of Cancer) klasifikatoru - audzējs tiek klasificēts četrās stadijās, atkarībā no tā izplatības primārajā orgānā, reǵionālajos limfmezglos un citos orgānos. Saskaņā ar šo klasifikāciju pacientiem ar I stadijas kolorektālo vēzi 5 gadu izdzīvotība ir 93 \%, II stadijas pacientiem - $80 \%$, bet III stadijas pacientiem - $60 \%$. Tomēr AJCC klasifikācijā netiek identificēti augsta riska pacienti, kuriem nepieciešama adjuvanta ķīmijterapija. 18 gēnu ekspresijas analīze ļauj izdalīt II stadijas zema riska pacientus (60\%) un augsta riska pacientus (40 \%), kuriem papildu adjuvanta ķīmijterapija uzlabo izdzīvotības rezultātus (Salazar et al., 2011).

Perez-Villamil apraksta piecus kolorektālā vēža molekulāri ǵenētisko tipus: stromas nabadzīgs (angl. low-stroma) apakštips, imūnglobulīna apakštips, stromas bagātīgs (angl. high-stroma) apakštips, mucinozais apakštips un neklasificēts apakštips. Mucinozam apakštipam raksturīga mucīna ekspresija, $B R A F$ mut un MSI. Stromas bagātīgajam apakštipam raksturīgs paaugstināts ekstracelulārās matrices un audzēja stromas komponentu daudzums. Stromas nabadzīgajam apakštipam raksturīga vislabākā prognoze (Perez-Villamil et al., 2012).

Sadanandam et al. 2013. gadā iedalīja kolorektālā vēzi piecos apakštipos atkarībā no gēnu ekspresijas profila: 1) kausam līdzīgais (angl. goblet-like) apakštips ar augstu MUC2 un TFF3 ekspresiju, 2) enterocītu apakštips ar enterocītiem specifisko gēnu pārekspresiju, 3) cilmšūnām līdzīgais (angl. stem-like) apakštips ar augstu Wnt signālu pārvades ceḷa molekulu ekspresiju, mezenhimālo un mielepiteliālo gēnu ekspresiju, ar cilmšūnu klātbūtni, 4) inflamatorais apakštips ar augstu citokīnu un ar iekaisumu saistīto gēnu ekspresiju un 5) pastiprinātas signālpārvades (angl. transit-amplifying) apakštips ar cilmšūnu un Wnt mērksa gēnu pārekspresiju. Šajā pētījumā tika atklāts, ka epiregulīna un amfiregulīna ekspresija ir pozitīvs anti-EGFR terapijas prediktīvais faktors, bet filamīna, kas regulē c-Met receptora ekspresiju un signālu pārvadi, pārekspresija konstatēta audzējos, kas bija rezistenti uz 
anti-EGFR terapiju un jutīgi uz MET inhibitoru terapiju. Stem-like apakštipam bija raksturīga agrīna pēcoperācijas progresija un vislielākais adjuvantās ķīmijterapijas ieguvums (Perez-Villamil et al., 2012; Sadanandam et al., 2013).

Izmantojot daudzus kolorektālā vēža pacientu genomu pētījumus, tika veikta apkopojoša bioinformātikas analīze un izveidota jauna CMS (angl. Consensus molecular subtype) klasifikācija (1.1. tabula). Arī šī klasifikācija nav ideāla; tālākajos pētījumos grupas tika dalītas apakšgrupās (Guinney et al., 2015).

Interesanti, ka dažādiem CSM apakštipiem atrod atšķirīgu mikrobiomu. Visvairāk mikrobu sugu, ieskaitot Fusobacterium hwasookii un Porphyromanas gingivalis, raksturīgas CSM1 apakštipam, bet CSM2 apakštipam ir raksturīgi Selemonas un Prevotella sugu pārstāvji (Purcell et al., 2017).

1.1. tabula

CMS (Consensus molecular subtype) klasifikācija (Guinney et al, 2015)

\begin{tabular}{|c|c|c|c|c|c|}
\hline $\begin{array}{l}\text { G̦enētiskās } \\
\text { izmaiṇas }\end{array}$ & $\begin{array}{l}\text { Audzēja } \\
\text { lokalizācija } \\
\text { (proksimāls } \\
\text { (P) vai } \\
\text { distāls (D)) }\end{array}$ & Prekursors & Gēnu ekspresija & $\begin{array}{l}\text { Mērķa } \\
\text { molekulas } \\
\text { (medikamenti) }\end{array}$ & Prognoze \\
\hline \multicolumn{6}{|c|}{ CMS1 (Biežums - 14 \%, hipermutēts tips) } \\
\hline $\begin{array}{l}\text { Hipermutēts } 95 \\
\% \\
\text { MSI } 70 \% \\
\text { CIMP }^{+} 65 \% \\
\text { CIN } 20 \% \\
B R A F \text { mut } 40 \% \\
\text { APC } 35 \% \\
T P 5330 \% \\
\text { KRASmut } 25 \%\end{array}$ & $\begin{array}{l}74 \% \mathrm{P} \\
26 \% \mathrm{D}\end{array}$ & $\begin{array}{l}\text { Zobainais } \\
\text { polips }\end{array}$ & $\begin{array}{l}\text { PD1 ekspresija, } \\
\text { NK (natural } \\
\text { killer) limfocītu } \\
\text { infiltrācija, } \\
\text { vāja stromāla } \\
\text { infiltrācija }\end{array}$ & $\begin{array}{l}\text { Imūnšūnas } \\
\text { (check-point } \\
\text { inhibitori) }\end{array}$ & $\begin{array}{l}\text { Vidēja } \\
\text { prognoze } \\
\text { Tiek } \\
\text { diagnosticēti } \\
\text { agrīni } \\
\text { Progresijas } \\
\text { gadījumā } \\
\text { prognoze } \\
\text { slikta } \\
\end{array}$ \\
\hline \multicolumn{6}{|c|}{ CMS2 (biežums - 40 \%, kanonisks tips) } \\
\hline $\begin{array}{l}\text { Hipermutēts } 2 \\
\% \\
\text { MSI } 2 \% \\
\text { CIMP }^{+} 4 \% \\
\text { CIN } 96 \% \\
B R A F \text { mut } 0 \% \\
A P C 80 \% \\
\text { TP } 5370 \% \\
\text { KRASmut } 30 \%\end{array}$ & $\begin{array}{l}20 \% \mathrm{P} \\
80 \% \mathrm{D}\end{array}$ & $\begin{array}{l}\text { Tubulāra } \\
\text { adenoma }\end{array}$ & $\begin{array}{l}\text { Epiteliāla } \\
\text { diferenciācija, } \\
\text { WNT un MYC } \\
\text { ekspresija, } \\
\text { Src un šūnas cikla } \\
\text { pastiprināta } \\
\text { regulācija, } \\
\text { miR 17-92 } \\
\text { pastiprināta } \\
\text { ekspresija, } \\
\text { loti vāja imūno } \\
\text { šūnu infiltrācija }\end{array}$ & $\begin{array}{l}\text { EGFR (EGFR } \\
\text { inhibitori) } \\
\text { HER2 (HER2 } \\
\text { blokatori) }\end{array}$ & $\begin{array}{l}\text { Laba } \\
\text { prognoze }\end{array}$ \\
\hline
\end{tabular}


1.1. tabulas turpinājums

\begin{tabular}{|c|c|c|c|c|c|}
\hline $\begin{array}{l}\text { Ģenētiskās } \\
\text { izmaiņas }\end{array}$ & $\begin{array}{l}\text { Audzēja } \\
\text { lokalizācija } \\
\text { (proksimāls } \\
\text { (P) vai } \\
\text { distāls (D)) }\end{array}$ & Prekursors & Gēnu ekspresija & $\begin{array}{l}\text { Mērksa } \\
\text { molekulas } \\
\text { (medikamenti) }\end{array}$ & Prognoze \\
\hline \multicolumn{6}{|c|}{ CMS3 (biežums - $10 \%$, metabolisks tips) } \\
\hline $\begin{array}{l}\text { Hipermutēts } 30 \\
\% \\
\text { MSI } 15 \% \\
\text { CIMP }^{+} 21 \% \\
\text { CIN } 54 \% \\
B R A F \text { mut } 10 \% \\
\text { APC } 75 \% \\
\text { TP53 } 30 \% \\
\text { KRASmut } 70 \%\end{array}$ & $\begin{array}{l}55 \% \mathrm{P} \\
45 \% \mathrm{D}\end{array}$ & Nezināms & $\begin{array}{l}\text { Multipla metabolo } \\
\text { faktoru ekspresija, } \\
\text { epiteliāa } \\
\text { diferenciācija, } \\
\text { vāja imūnā } \\
\text { infilttrācija, } \\
\text { l’oti vāja stromāla } \\
\text { infiltrācija }\end{array}$ & & $\begin{array}{l}\text { Vidēja } \\
\text { prognoze }\end{array}$ \\
\hline \multicolumn{6}{|c|}{ CMS4 (biežums - 25 \%, mezenhimāls tips) } \\
\hline $\begin{array}{l}\text { Hipermutēts } 2 \\
\% \\
\text { MSI } 3 \% \\
\text { CIMP }^{+} 9 \% \\
\text { CIN } 86 \% \\
\text { BRAFmut } 5 \% \\
\text { APC } 65 \% \\
\text { TP53 } 55 \% \\
\text { KRASmut } 40 \%\end{array}$ & $\begin{array}{l}34 \% \mathrm{P} \\
66 \% \mathrm{D}\end{array}$ & $\begin{array}{l}\text { Zobainais } \\
\text { polips }\end{array}$ & $\begin{array}{l}\text { Epiteliālās- } \\
\text { mezenhimālās } \\
\text { pārveides gēnu } \\
\text { pārekspresija, } \\
\text { TGF- } \beta \text { signālu cel̦a } \\
\text { aktivācija, } \\
\text { angioğenēzes } \\
\text { remodulācija, } \\
\text { izteikta stromāla } \\
\text { infiltrācija, } \\
\text { VEGF/VEGFR un } \\
\text { integrīna } \beta 3 \\
\text { signālu pārvade }\end{array}$ & $\begin{array}{l}\text { PDGFR } \\
\text { KIT } \\
\text { HSP90 }\end{array}$ & $\begin{array}{l}\text { Slikta } \\
\text { prognoze } \\
\text { (gan kopējā, } \\
\text { gan } \\
\text { bezrecidīva } \\
\text { dzīvildze) } \\
\text { Audzējs } \\
\text { parasti tiek } \\
\text { diagnosticēts } \\
\text { III-IV } \\
\text { stadijā. }\end{array}$ \\
\hline
\end{tabular}

BRAFmut - b-Raf onkogēna mutācija, KRASmut - Kirsten Ras onkogēna mutācija, $A P C$ - zarnu adenomatozās polipozes gēns, MSI - mikrosatelītu nestabilitāte, CIMP - CpG metilācijas fenotips, CIN - hromosomālā nestabilitāte, EGFR - epidermālā augšanas faktora receptors, PD1 - programmētās šūnas nāves proteīns 1, HER2 - cilvēka epidermālā auǵšanas faktora receptors 2, VEGF - vaskulārā endotēlija augšanas faktors, HSP90 karstuma šoka proteīns 90, KIT - cilmšūnas augšanas faktora receptors Kit, , PDGFR - trombocìtu augšanas faktora receptors

\subsection{Kolorektālā vēža molekulāri g̀enētiskais raksturojums}

Vēža genoma atlanta (angl. The Cancer Genome Atlas (TCGA)) pētījumi parāda, ka $16 \%$ resnās zarnas vēža gadījumu novēro hipermutāciju (75 \% augsta mikrosatelītu nestabilitāte, saistīta ar hipermetilēšanu un MLH1 inaktivāciju (angl. silencing), bet 25 \% polimerāzes gēna un DNS reparācijas gēnu mutācijas); nehipermutēta kolorektāla vēža gadījumā atrod konsekventu mutāciju "rakstu" ar 24 bieži sastopamiem mutētiem gēniem (t.sk. APC, TP53, SMAD4, PI3KCA, KRAS, SOX9, FAM123B un ARID1A). Hipermutētajos audzējos biežāk sastopamās mutācijas: ACVR2A (63\%), APC (51 \%), TGFBR2 (51 \%), BRAF (49\%), MSH3 (46\%), MSH6 (40\%), MYO18 (31\%), CASP8 (31\%), TCF7L2 (29\%) gēnos. Divas gēnu mutācijas, kas ir biežāk novērojamas nehipermutēta kolorektālā vēža gadījumos, ir 
retākas hipermutētā audzējā - APC (81 \% vs 51 \%) un TP53 (60 \% vs 20 \%) (CGAN, 2012). Hipermutētie audzēji var tikt iedalīti divās grupās: ultrahipermutētie audzēji (3 \% gadījumu) ar DNS replikācijas enzīma polimerāzes E inaktivāciju un pārējie hipermutētie audzēji (13\% gadījumu) ar MSI. Papildus šīm mutācijām novēro ERBB2, MYC un IGF2 amplifikācijas izmaiņas un hromosomālo translokāciju ar NAV2 gēna un Wnt signālu pārvades ceḷa gēna TCF7L1 saplūšanu (angl.fusion gene). 93 \% hipermutētu audzēju gadījumu ir deaktivizēts Wnt signālu pārvades ceḷš, bet ievērojami biežāk nekā nemutētos audzējos novēro TGF- $\beta$ signālu pārvades ceḷa izmainas (87 \% vs $27 \%$ ) un RAS/RTK signālu pārvades ceḷa mutācijas (80\% vs $59 \%)$.

Turpmākajā TCGA kolorektālā vēža proteoma analīzē identificēti pieci apakštipi. Visi hipermutētie un MSI-H audzēji attiecas uz B un C apakštipu. B apakštipa audzēji ir saistīti ar CIMP+ apakštipu, TP53 inaktivāciju un hromosomas 18q zudumu (delēciju), bet C apakštipam ir raksturīga CIMP. Pārējie apakštipi - A, D un E - ir saistīti ar CIN. E apakštips ir saistīts ar TP53 mutācijām un 18q zudumu, kā arī ar HNF4A amplifikāciju (Bass et al., 2011).
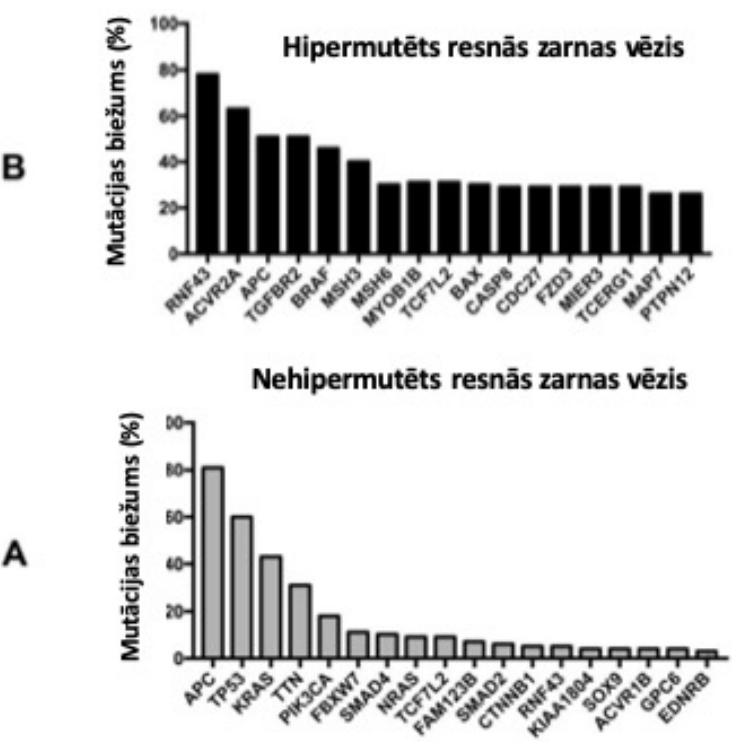

\section{9. att. Kolorektālā vēža visbiežākās gēnu mutācijas}

A. Hipermutētu audzēju biežākās gēnu mutācijas. B. Nehipermutētu audzēju biežākās gēnu mutācijas (Cancer Genome Atlas Network, 2012)

Vēža genoma sekvenēšana pierāda, ka genomiskā nestabilitāte ir būtiska kolorektālā vēža paz̄ime, kas ir īpaši raksturīga nehipermutētajiem audzējiem. Kopiju skaita variāciju izpēte ir ḷāvusi identificēt izmaiṇas audzēja nomācējgēnos, kā arī identificēt gēnu translokācijas un saplūšanas (VTIA-TCF7L2, R-spondīna fusion gēnu, receptoru tirozīnkināžu kodējošo gēnu translokācijas, RSPO2, NTRK3, ERAS un BRAF gēnu translokācijas), (CGAN, 2012; Bass et al., 2011; Kloosterman et al., 2017). 
Iepriekš jau tika minēts, ka TGF- $\beta$ saimes mutācijas ir loti biežas kolorektālā vēža šūnās. Šūnas membrānas receptori TGFBR1 un TGFBR2 tiek aktivizēti pēc TGF- $\beta$ liganda piesaistī̌̌anās, notiek sekojoša ar receptoru saistīto SMAD2 un SMAD3 fosforilěšana, SMAD4 piesaistī̌anās. Rezultātā molekulārais komplekss šūnas kodolā regulē mērka gēnus. Sporādiskā kolorektālā vēža gadījumā TGFBR2 un SMAD4 mutācijas ir sastopamas attiecīgi $15 \%$ un 10 \% pacientu, tās prevalē audzējos ar MSI (Iacopetta et al., 1998), bet SMAD, SMAD2 un SMAD3 mutācijas ir sastopamas 8,6 \%, 3,2 \% un 4,3\% pacientu (Fleming et al., 2013). TGF- $\beta$ mutācijas tiek novērotas plakanā zobainā polipa onkoǵenēzes procesā, tam transformējoties mezenhimālā tipa kolorektālajā audzējā (Fessler et al., 2016).

\subsubsection{KRAS gēns}

KRAS (Kirsten Ras oncogene homolog) ir metastātiska kolorektālā vēža prediktīvs faktors, jo KRAS gēna mutācija ir biežākais anti-EGFR antivielu rezistences iemesls (Lievre et al., 2006). KRAS pieder RAS gēnu saimei (KRAS, NRAS, un HRAS), kas kodē guanozīn-5'-trifosfātu (GTP) saistošos proteīnus. 32-40\% pacientu ar kolorektālo vēzi tiek konstatēta KRAS mutācija. Aptuveni 85-90 \% no mutācijām ir KRAS gēna 12. vai 13. kodonā. Atlikušās mutācijas pārsvarā konstatē 61. kodonā (5 \%) un 146. kodonā (5 \%) (Allegra et al., 2009; De Roock et al., 2010). KRAS ir svarīgs EGFR receptora efektors, kas nodrošina signālu pārnesi šūnā caur BRAF un MAPK signālu pārvades kaskādi. KRAS proteīnu var aktivizēt $P I 3 K$, ar to tieši mijiedarbojoties. KRASmut kolorektālais vēzis parasti ir labi diferencēta adenokarcinoma ar mikrosatelītu stabilu fenotipu.

Pacientiem ar mKRV, kuri san,em terapijā anti-EGFR monoklonālās antivielas, KRAS mutācijai ir vairāk prediktīva, nekā prognostiska vērtība. Randomizēta pētījuma CRYSTAL (Van Cutsem et al., 2009), kurā tika iekḷauti 540 pacienti ar metastātisku kolorektālo vēzi, kas saṇēma anti-EGFR monoklonālo antivielu cetuksimabu kopā ar paliatīvu k,īmijterapiju, retrospektīvajā analīzē tika pierādīta sakarība starp KRAS gēna statusu un terapijas efektivitāti (audzēja atbildes reakciju, bezprogresijas un kopējo dzīvildzi) - terapija ir efektīvāka pacientiem bez KRAS mutācijas (t.i., KRASwt) (Van Cutsem et al., 2009).

Tomēr līdz 50-65 \% pacientu ar KRASwt audzēju ir sākotnēji rezistenti pret anti-EGFR monoklonālo antivielu terapiju, ko var izraisīt citas ǵenētiskās izmaiņas. Piemēram, $B R A F$, NRAS un PIK3CA mutācijas un to kombinācijas var izraisīt rezistenci pret anti-EGFR terapiju pacientiem bez KRAS mutācijas (Laurent-Puig et al., 2009; Sartore-Bianchi et al., 2009; Di Nicolantonio et al., 2008). Primāro un iegūto rezistenci pret anti-EGFR terapiju izraisa arī samazināta liganda un receptora mijiedarbība, alternatīvo signālu pārvades ceḷu aktivitāte 
(MEK-ERK) un mutācijas ERBB2, EGFR, FGFR1, PDGFRA un MAP2K1 gēnos (Mao et al., 2011; Hurwitz et al., 2009).

KRAS saistība ar citu medikamentu aktivitāti nav skaidra un vēl tiek pētīta. Hurwitz et al. pêtījuma retrospektīvā analīze pierāda angioğenēzes inhibitora bevacizumaba efektivitāti neatkarīgi no KRAS stāvokḷa (Hurwitz et al., 2009). MRC FOCUS pētījuma (Seymour et al., 2007) vēlākā Richman et al. retrospektīvā analīze parādīja, ka KRAS mutācija neietekmē oksaliplatīna un irinotekāna terapijas efektivitāti (Richman et al., 2009).

Sakarā ar to, ka pacientiem ar KRAS mutāciju cetuksimabs un panitumumabs nav efektīvi, tiek meklēti citi medikamenti, ar kuru palīdzību rastos iespēja pagarināt pacientu dzīvildzi. Preklīniskajos pētījumos ir atklāts, ka vēža šūnās ar KRAS mutāciju ir aktīvs C-RAF signālu pārvades ceḷ̌s, kuru ir iespējams inhibēt ar multikināžu inhibitoru sorafenib (Takezawa et al., 2009; Haigis et al., 2008).

\subsection{2. $B R A F$ gēns}

BRAF (B-Raf oncogene) pieder RAF gēnu saimei (BRAF, ARAF1, un RAF1), kodē serīna-treonīna proteīnkināzi, un ir iesaistīts RAS/RAF/MAPK signālu pārnesē. Aptuveni 6-15 \% kolorektālo audzēju ir mutācija BRAF gēnā (Di Nicolantonio et al., 2008). Ir pierādīta BRAF mutācijas saistība ar nelabvēlīgu prognozi vairākos metastātiska kolorektālā vēža pētījumos (De Roock et al., 2010; Van Cutsem et al., 2010; Van Cutsem et al., 2009). Souglakos et al., 2011. gada pētîjuma publikācijā pacientiem ar BRAF mutāciju bija statistiski ticami īsāka bezprogresijas dzīvildze (4,3 vs 12,5 mēneši, p < 0,0001) un kopējā dzīvildze (10,9 vs 40,5 mēneši, $\mathrm{p}<0,0001)$. Hipermutēta kolorektālā vēža šūnās $B R A F$ mut konstatēta $47 \%$, bet nehipermutēta vēža šūnās - 3 \% gadījumu (Safaee Ardekani et al., 2012).

Līdz pat $95 \%$ gadījumu mutācija tiek konstatēta B-RAF proteīna kināzes aktivācijas domēnā V600E. Līdz šim vēl nav zināms kā mainās signālu pārnese šūnās ar BRAF mutāciju pēc liganda piesaistīšanās EGF receptoram. Pastāv uzskats, ka signālu pārnese ir līdzīga kā šūnās ar $K R A S$ mutāciju. Tomēr ir dati, ka audzējiem ar $K R A S$ mutāciju un audzējiem ar $B R A F$ mutāciju ir atškirīgs gan morfoloğiskais veids, gan klīniskās izpausmes. BRAF mutācija ir asociēta ar CIMP+ fenotipu (CpG island methylator phenotype) un mikrosatelītu nestabilitāti, lielāku pacientu vecumu (> 60), zemāku audzēja diferenciācijas pakāpi. pie tam - biežāk BRAF mutācija tiek konstatēta sievietēm. KRAS mutācija proporcionāli biežāk sastopama audzējos ar CIMP fenotipu un stabilu mikrosatelītu stāvokli, augstāku audzēja diferenciācijas pakāpi. Atšķirībā no KRAS mutācijas, kas statistiski neietekmē pacientu dzīvildzi, BRAF mutācija ir kolorektālā vēža nelabvēlīgs prognostiskais faktors (Roth et al., 2010). 
$B R A F$ V600E mutācija ir saistīta ar rezistenci pret anti-EGFR monoklonālo antivielu terapiju pacientiem ar KRASwt tipa metastātisku kolorektālo vēzi. Nevienam no Laurent-Puig et al., 2009.gada un Di Nicolantonio et al., 2008.gada pētījumos ieklautajiem pacientiem, kuriem konstatēta mutācija $B R A F$ gēnā, bet nav izmainīts $K R A S$ gēns, netika konstatēta pozitīva atbildes reakcija uz anti-EGFR terapiju.

De Rock et al., 2010.gada pētījumā tikai 8,3 \% pacientu ar mutētu BRAF gēnu novērota audzēja mazināšanās pēc anti-EGFR monoklonālās antivielas cetuksimab terapijas, salīdzinot ar 38,0 \% pacientiem ar neizmainītu BRAF stāvokli $(\mathrm{p}=0,0012)$. Pacientiem, kas tika iekḷauti CRISTAL pētījumā, retrospektīvi $B R A F$ mutācija tika konstatēta $6 \%$ gadījumu. Pacientiem ar $K R A S w t$ tipa audzēju, kas san̄ēma FOLFIRI ar vai bez cetuksimab, BRAF mutācija korelēja ar īsāku bezprogresijas un kopējo dzīvildzi (Van Cutsem et al., 2010).

Pacientiem ar mKRV BRAF V600E mutāciju audzēja šūnās ir efektīva BRAF inhibitoru (vemurafeniba, dabrafeniba, enkorafeniba) un MEK inhibitoru (trametiniba, binimetiniba) kombinētā terapija (Kopetz et al., 2019; Van Cutsem et al., 2019).

\subsubsection{PI3K gēns}

PI3K (Phosphoinositide-3-kinase) ir lipīdu kināžu saime, kurā ietilpst 3 lipīdu kināžu klases. Ia klases PI3K aktivācija notiek brīdī, kad augšanas faktors (ligands) piesaistās atbilstošam tirozinnkināzes receptoram (ERBB, PDGFR, IGF1R receptoru saime). Biežāk saistībā ar onkoǵenēzi literatūrā aprakstīta ir PIK3CA mutācija, kas ir atrodama 15-18\% pacientu ar kolorektālo vēzi. (Nosho et al., 2008; Barault et al., 2008; Souglakos et al., 2009). PIK3CA mutācija $80 \%$ gadījumos ir atrodama 9. vai 20. eksonā vai abos vienlaicīgi; tā var kombinēties gan ar KRAS, gan BRAF mutāciju (De Roock et al., 2010).

PIK3CA 20. eksona mutācija ir saistīta ar anti-EGFR monoklonālo antivielu terapijas rezistenci pacientiem ar KRASwt tipa audzēju, bet PIK3CA 9. eksona mutācija ir atrodama tikai pacientiem ar KRAS mutāciju (Sartore-Bianchi et al., 2009; Prenen et al., 2009).

De Rock et al. pētījumā netika atklāta cetuksimab terapijas efektivitātes saistība ar PIK3CA 9. eksona mutāciju, bet pacientiem ar 20. eksona mutāciju konstatēta vājāka audzēja atbildes reakcija (0 vs 36,8 \%,p = 0,029), īsāka bezprogresijas dzīvildze (11,5 vs 24,0 mēneši, p = 0,013) un īsāka kopējā dzīvildze (34 vs 51 mēneši, p = 0,0057), (2010). Turpretī, Souglakos et al. pētījumā netika atklāta statistiski nozīmīga cetuksimaba un panitumumaba efekivitātes atškirība pacientiem ar PIK3CA mutāciju (2009). 2011. gadā publicētajā metaanalīzē, kurā iekḷauti 377 pacienti ar PIK3CA mutāciju un KRASwt tipa audzēju, tika apstiprināta PIK3CA saistība ar cetuksimab rezistenci. Novērota vāja audzēja atbildes reakcija ( 0 vs $37 \%, p=0,082)$, 
īsāka bezprogresijas dzīvildze (HR 2,52, p = 0,013) un kopējā dzīvildze (HR 3,29, p = 0,006) (Mao et al., 2011).

Tā kā PI3K ir IGF1R signālu pārneses ceḷa mediators, iespējams, ka nākotnē PIK3CA mutācija būs nozīmīgs IGF1R inhibitoru terapijas efektivitātes rādītājs.

\subsubsection{PTEN gēns}

PTEN (Phosphatase And Tensin Homolog) inhibē PI3K iniciētu signālu pārvadi. Izmaiṇas audzēja šūnās ir saistītas tieši ar PTEN gēna aktivitātes zudumu, kā rezultātā veidojas patoloğiska un nekontrolēta signālu pārvade šūnā. PTEN aktivitātes zudumam ir dažādi mehānismi - mutācija PTEN gēnā, 10q23 hromosomas defekts (alēles zudums) vai PTEN promotera reǵiona hipermetilācija (De Roock et al., 2011)

PTEN nozīme ir aprakstīta saistībā ar trastuzumab rezistenci pacientēm ar HER2 pozitīvu krūts vēzi, bet tā nozīme kolorektālā vēža attīstībā un terapijas efektivitātē vēl līdz galam nav noskaidrota. Dažādos pētījumos PTEN ekpresijas zudums variē no $19 \%$ līdz $36 \%$ (Laurent-Puig, 2009; Frattini et al., 2007). PTEN zudums tiek konstatēts biežāk pacientiem, kuriem ir EGFR inhibitoru terapijas rezistence. Laurent-Puig et al. pētījumā pacientiem, kas saṇēma cetuksimabu metastātiska kolorektālā vēža ārstēšanā un kuriem vēža audos konstatēts PTEN zudums, tika aprakstīta vājāka audzēja atbildes reakcija un īsāka kopējā dzīvildze $(\mathrm{p}=0,013),(2009)$.

\subsubsection{EGFR}

EGFR (Epidermālā augšanas faktora receptora) izmaiṇas ir pêtītas saistībā ar anti-EGFR monoklonālo antivielu efektivitāti. 7. hromosomas polisomijas izraisīta EGRF gēna kopiju skaita palielināšanās (3-5 reizes) ir aprakstīta vairākos mērḳa terapijas pētījumos. Ir pierādīts, ka pacientiem ar palielinātu EGFR gēna kopiju skaitu ir statistiski ticami labāka audzēja atbildes reakcija un garāka bezprogresijas un kopējā dzīvildze, saṇemot cetuksimaba vai panitumumaba terapiju (Moroni et al., 2005; Sartore et al., 2007; Personeni et al., 2008; Cappuzzo et al., 2008).

Galvenās diagnostiskās metodes ir fluorescenta in situ hibritidizācija (FISH) (Ooi et al., 2004) un homogēnā in situ hibritidizācija (CISH) (Shia et al,, 2005). Ir nepieciešami prospektīvi randomizēti pētījumi, lai atrastu labāko diagnostisko metodi EGFR stāvokḷa noteikšanai un izvērtētu tā nozīmi metastātiska kolorektālā vēža pacientu ārstēšanā. 


\subsection{Vēlīns jeb metastātisks kolorektālais vēzis}

Metastātisks kolorektālais vēzis ir saslimšana ar ierobežotu dz̄ivildzi, līdzīgi kā lielākā daḷa citu lokalizāciju metastātiski audzēji. Ārstēšanas galvenie aspekti ir slimības simptomu kontrole, dzīves ilguma pagarināšana, dzīves kvalitātes uzlabošana.

Aptuveni 50-60 \% pacientu, kuriem anamnēzē ir veikta radikāla I-III stadijas kolorektālā vēža operācija, dzīves laikā attīstās metastāzes, bet tikai 10-20\% pacientu no visiem mKRV pacientiem ir iespējama radikāla metastāžu rezekcija (Van Cutsem et al., 2006).

Metastāzes attīstās biežāk secīgi (metahroni) pēc primārā audzēja ārstēšanas, tomēr 20-34 \% metastāzes konstatē vienlaicīgi (sinhroni) ar primāro audzēju resnajā vai taisnajā zarnā (primārs metastātisks kolorektāls vēzis), (Hayashi et al., 2010). Biežākā metastāžu lokalizācijas vieta ir aknas (Fong et al., 1997).

Primārs metastātisks vēzis asociējas ar plašāku procesa disemināciju un nelabvēlīgāku prognozi, salīdzinot ar metahronu metastātisku procesu. Retrospektīvā pētījumā pierādīts, ka pacientiem ar sinhronām metastāzēm biežāk tās lokalizējas abās aknu daivās $(\mathrm{p}=0,016)$ un ir multiplas $(\mathrm{p}=0,008)$, salīdzinot ar pacientiem, kuriem ir metahronas metastāzes (Tsai et al., 2007).

Lielākā dala molekulāro pētījumu ir veikti, analizējot tieši metastātiska kolorektālā vēža paraugus. Nesen publicētā liela apjoma analīzē par metastātiskā kolorektālā vēža genomu tika izdalītas trīs apakšgrupas: POLE mut (0,7 \%), MSI-H (8,7\%) un MSS (90,5\%). MSS audzēji galvenokārt bija vidēji diferencēta adenokarcinoma ar primāro lokalizāciju zarnas kreisajā pusē, bet POLEmut un MSI-H audzēji - pārsvarā zemu diferencēti mucinozi audzēji zarnas labajā pusē (Yaeger et al., 2018). Biežākās mutācijas MSS mKRV šūnās ir APC (79 \%), TP53 (78 \%), KRAS (44\%), PIK3CA (18\%), SMAD4 (16\%), TCF7L2 (10\%) un FBXW7 (10\%) gēnos. Analīzē atklātas arī retāk sastopamas (1-4 \% gadījumu) mutācijas: PTPRS, PIK3GG, FLT4, $M A P 2 K 4, I K 2 F 1, J U N, T B X 3, F O X P 1$, INHBA un CDKN1B gēnos. Labās puses mKRV gadījumā biežāk atrada izmaiņas KRAS, PIK3CA, BRAF, PTEN, AKT1, RNF43, SMAD2 un SMAD4 gēnos, bet kreisās puses audzējiem biežāk konstatētas APC un TP53 mutācijas (Yaeger et al., 2018).

Pirmais fundamentālais pētījums, kas publicēts 1990. gadā, atklāja 3 \% mutāciju, kas tika konstatētas metastāzēs, bet netika konstatētas primārajā audzējā (Fearon et Vogelstein, 1990). Turklāt pacientiem, kuriem resnajā zarnā bija saglabājusies adenoma, no kuras attīstījās audzējs, tika konstatēta 30 \% mutāciju atškirīiba starp adenomu un ḷaundabīgo audzēju (Fearon et Vogelstein, 1990). Galvenās mutācijas (KRAS, TP53, APC, PIK3CA, BRAF un NRAS gēnos) parasti ir līdzīgas primārajā audzējā un metastāzēs, neatkarīgi vai tās ir sinhronas vai metahronas (Kim et al., 2017). 


\subsection{Metastātiska kolorektālā vēža ārstēšana}

Metastātiska resnās zarnas vēža pacienta ārstēšana ir multidisciplināra - ārstēšanas gaitā vienlīdz liela nozīme ir k,irurǵiskai ārstēšanai (primārā audzēja un limfmezglu metastāžu rezekcija, aknu un plaušu metastāžu rezekcija), medikamentozai terapijai, t.sk. ḳīmijterapijai un mērḳterapijai, lokāli invazīvām manipulācijām (radiofrekvences ablācija, transarteriāla k̦īmijembolizācija), staru terapijai (nerezecējama primārā audzēja apstarošana, aknu metastāžu stereotaktiska apstarošana, pretsāpju staru terapija), simptomātiskai terapijai un aprūpei. Kombinējot vai secīgi pielietojot visas ārstēšanas metodes, tiek būtiski paildzināta dzīvildze, kā arī uzlabota pacienta dz̄ives kvalitāte. Šì pieeja tiek dēvēta par terapijas nepārtrauktību (angl. continium of care), ārstēšana tiek plānota un vadīta no diagnozes brīža līdz dzīves noslēgumam.

Metastātiska KRV ārstēšana būtiski atšḳiras, ja metastāzes ir iespējams radikāli operēt (rezecējams mKRV). Šajā gadījumā mērḳis ir pacientu izārstēt vai būtiski pagarināt dzīvildzi. Ja slimība sākotnēji ir izplatīta un visas metastāzes kirurğ́iski nav iespējams evakuēt (nerezecējams mKRV), paciena pamatārstēšanas veids ir vairāku līniju paliatīva medikamentoza terapija (ḳīmijterapija, mērķterapija, imūnterapija) ar mērḳi pagarināt bezprogresijas izdzīvotību un kopējo izdzīvotību, kā arī uzlabot dzīves kvalitāti.

\subsubsection{Rezecējama metastātiska kolorektālā vēža ārstēšana}

Ķirurğiska operācija ir galvenā lokalizēta vai lokāli izplatīta resnās un taisnās zarnas vēža ārstēšanas metode, bet pacientiem ar metastātisku vēzi radikālas kirurğiskās ārstēšanas iespējas ir nelielas.

Pacientiem ar mKRV dzīvildze ir īsa gadījumos, ja nav iespējama radikāla k,irurğiska ārstēšana. Tādi faktori kā ekstrahepātiskas metastāzes un multiplas metastāzes norāda uz nelabvēēīgu prognozi ar īsāku laiku līdz progresijai (< 12 mēneši), (Michihiro et al., 2010; Pawlik et al., 2005; Choti et al., 2002).

Turpretī pacientiem pēc radikālas metastāžu rezekcijas 5 gadu kopējā dzīvildze pēc dažādu pētījumu datiem ir no $20 \%$ līdz $58 \%$, vidējā dzīvildze - 24 līdz 46 mēneši (Choti et al., 2002; Fong et al., 1999; Nakamura et al., 1999). Jāatzīmē, ka 57-78 \% pacientu pēc aknu metastāžu rezekcijas attīstās slimības recidīvs (Nakamura et al., 1999; Assumpcao et al., 2008). Iemesli tam varētu būt primārā audzēja mikrometastāzes, kuras nav iespējams diagnosticēt un ķirurğiski evakuēt, kā arī reziduālas audzēja šūnas, kas paliek aknās pēc metastāžu rezekcijas (audzēja šūnas rezekcijas līnijā vai reziduālas metastāzes).

Pacientiem, kuriem tiek diagnosticēts primāri metastātisks kolorektāls vēzis ar rezecējamām metastāzēm, būtu jāveic gan primārā tumora rezekcija, gan metastazektomija. 
Nav stingri definētu vadlīniju, kas noteiktu, vai primārā audzēja operācijai un metastāžu rezekcijai ir jābūt vienā vai vairākos etapos veicamai operācijai. Pētījumos ir aprakstīta vairāku etapu kirurğiskā pieeja, sākot ar primārā audzēja rezekciju un sekojošu metastāžu rezekciju pēc 2-3 mēnešiem (Schlag et al., 1990; Jenkins et al., 1997). Vairākos pētījumos aprakstīts, ka simultāna primārā tumora un metastāžu rezekcija pagarina hospitalizācijas ilgumu, paaugstina perioperatīvo mortalitāti un morbiditāti, salīdzinot ar vairāku etapu operatīvo ārstēšanu (Fujita et al., 2000; Elias et al., 1995; Chua et al., 2004; Benoist et al., 2005; Lyass et al., 2001; Martin et al., 2003). Simultāna rezekcija var tikt veikta, ja ir paredzēta nekomplicēta hemikolektomija un solitāru aknu metastāžu rezekcija, bet komplicēta zarnas operāciju un plašu aknu metastāžu rezekciju vajadzētu veikt secīgi.

Pacientiem, kuriem nav akūtu obstrukcijas vai perforācijas simptomu, rekomendē ārstēšanu sākt ar neoadjuvantu kīmijterapiju. Perioperatīva kīimijterapija pagarina 3 gadu bezprogresijas intervālu par 7-9 \% (Nordlinger et al., 2008). Potenciālie ieguvumi no preoperatīvās k,īmijterapijas ir: metastāžu rezektabilitātes panākšana, agrīna mikrometastāžu terapija, ķ̄mijterapijas efektivitātes noteikšana, kas turpmāk ḷauj prognozēt slimības gaitu un izvēlēties adekvātu turpmāko medikamentozo terapiju, un pacientu atlase metastāžu rezekcijai, pirmsoperācijas etapā atsijājot pacientus ar agrīnu metastāžu progresiju vai vēža disemināciju . Pirmsoperācijas ḳīmijterapijas trūkumi ir oksaliplatīnu vai irinotekānu saturošas ḳīmijterapijas inducēts aknu toksisks bojājums - steatohepatīts. Toksicitātes dēl preoperatīvās k,īmijterapijas rekomendētais ilgums ir 2-3 mēneši, bet kopējais perioperatīvās ḳīmijterapijas rekomendētais ilgums ir 6 mēneši (Kishi et al., 2010; Vauthey et al., 2009; Choti et al., 2009; NCCN, 2019; ESMO, 2016).

K,īmijterapija var tikt nozīmēta pēc radikālas simultānas rezekcijas vai starpposmā starp primārā tumora un metastāžu rezekciju. Pacientiem, kuriem ir pozitīvs terapijas rezultāts, arī operācijas rezultāti ir labāki ar lielāku dzīvildzes ieguvumu, salīdzinot ar pacientiem, kuriem k̦īmijterapijas laikā konstatēta audzēja progresija. Pirmsoperācijas vai pēcoperācijas etapā izmantojamo k,īmijterapijas shēmu izvēle ir atkarīga no pacienta vispārējā objektīvā stāvokḷa, blakussaslimšanām, ḳīmijterapijas medikamentu iespējamās toksicitātes un efektivitātes.

Sākotnēji nerezecējamas metastāzes var tikt samazinātas pēc kombinētas ḳīmijterapijas, padarot tās rezecējamas $13 \%$ pacientu (Adam et al., 2001). Novērtējot sanemtās k,īmijterapijas efektivitāti, būtiska ir audzēja radioloğiskā atbildes reakcija - metastāžu izmaiņas datortomogrāfijas vai citā izmeklējumā. Audzēja samazināšanās (pozitīva dinamika) norāda uz ķīmijterapijas efektivitāti. Tomēr starp radioloğisko atbildes reakciju un patoloğisko atbildes reakciju nav stingras korelācijas. Pilna patoloǵiska remisija rezekcijas materiālā var tikt atrasta arī pacientiem, kuriem radioloğiskajos izmeklējumos ir bijusi tikai daḷēja remisija (Adam et al., 
2008), bet pacientiem ar pilnu radioloǵisku remisiju, kad radioloǵiskajos izmeklējumos metastāzes vairs neatrod, operācijas materiālā var tikt konstatēti mikroskopiski audzēja šūnu depozīti (Aucer et al., 2010; van Vledder et al., 2010). Pētījuma rezultāti liecina, ka, veicot rūpīgu pacientu atlasi un pielietojot agresīvu terapiju ar FOLFIRINOX un panitumumabu, ir iespējams sasniegt rezektabilitāti $60 \%$ pacientu ar sākotnēji nerezecējamām aknu metastāzēm (Geissler et al., 2017).

Lai panāktu labākus pēcoperācijas rezultātus, svarīga ir pacientu atlase operācijai (Van Cutsem et al., 2006; Charnsangavej et al., 2006). Mērkis ir visu metastāžu un primārā audzēja radikāla rezekcija un adekvāta aknu funkciju rezerve pēc operācijas. Ķirurğiskai rezekcijai ir jābūt radikālai (R0), jo nepilnīga metastāžu rezekcija vai citoreduktīva operācija nepagarina dzīvildzi (Altendorf-Hofmann et al., 2003; Yoo et al., 2006). Pētījumos ir aprakstīta pozitronemisijas tomogrāfijas (PET) nozīme pacientu pirmsoperācijas atlasē, ar kuras palīdzību iespējams atklāt iepriekš DT vai KMR nediagnosticētas metastāzes līdz pat $40 \%$ pacientu un sašaurināt radikāli operējamu pacientu loku (Lonneux et al., 2002; Desai et al., 2003; Bipat et al., 2005).

Ir pretrunīgi dati par k̦īmijterapijas turpināšanu pēc radikālas metastāžu rezekcijas pacientiem, kuri ķīmijterapiju ir saṇēmuši pirms operācijas. Randomizēta pētījuma rezultāti liecina, ka papildu 5-FU/LV pēcoperācijas kīmijterapija pagarina bezrecidīva dzīvildzi (27,9 vs 18,8 mēn., p = 0,058), bet statistiski neietekmē kopējo dzīvildzi (62,2 vs 47,3 mēn., $\mathrm{p}=0,095)$, (Mitry et al., 2008).

\subsubsection{Nerezecējama metastātiska kolorektālā vēža ārstēšana}

Paliatīva k,īmijterapija ir vien̄̄gā ārstēšanas metode, ar kuras palīdzību ir iespējams pagarināt bezprogresijas un kopējo izdzīvotību pacientiem ar nerezecējamu metastātisku kolorektālo vēzi. Pēdējā desmitgadē medikamentozās terapijas iespējas palielinās un tiek meklēta optimālā ārstēšanas stratēg̣ija un medikamenti, lai pagarinātu pacientu dzīvildzi, aizkavētu vēža progresiju, uzlabotu dzīves kvalitāti, atvieglotu simptomus.

Metastātiska kolorektālā vēža terapijā tiek izmantota viena vai vairāku medikamentu kombinācija, kas sastāv no tādiem praksē lietotiem medikamentiem kā: 5-fluorouracils (5-FU), leikovorīns (LV), kapecitabīns, oksaliplatīns, irinotekāns, bevacizumabs, cetuksimabs, panitumumabs (ESMO, 2016; NCCN, 2019). Šo medikamentu darbības mehānismi ir atškirīgi - citotoksiskie medikamenti ietekmē šūnas vielmaiņu un DNS replikāciju, bet bioloğiskie medikamenti ihibē receptorus (VEGFR un EGFR), ligandus (VEGF) un intracelulāro signālu kaskādi. Medikamentu izvēle ir balstīta uz potenciālo ārstēšanas ieguvumu, iepriekšējo ārstēšanu (iepriekšêjo adjuvanto un paliatīvo k,īmijterapiju), medikamentu atškirīgo toksicitātes 
profilu un ietekmi uz dzīves kvalitāti. K,īmijterapijas ilgums nav stingri definēts, ikdienas praksē k̦īmijterapija ilgst līdz vēža progresijai (medikamenta rezistences veidošanās) vai nepanesamai toksicitātei. Nav arī stingru rekomendāciju, kā ārstēt pacientu bez progresijas pēc pirmās līnijas terapijas pabeigšanas - uzsākt otrās līnijas terapiju, nozīmēt mazāk toksisku uzturošo k̦īmijterapiju vai tikai novērot līdz slimības progresijai. mKRV ārstēšana ir pagarinājusi pacienta dzīvildzi no 12 mēnešiem, izmantojot 5-FU monoterapijas, līdz > 20 mēnešiem, pielietojot 5-FU, oksaliplatīna un irinotekāna kombināciju (Chibaude et al., 2012). Dzīves ilgumam pieaugot, aizvien aktuālāks kḷūst jautājums, cik ilgi turpināt k̦īmijterapiju un vai ilgstoša terapija sniedz papildu dzīvildzes ieguvumu. Pētījumos apstiprināts, ka īsa oksaliplatīna saturoša pirmās līnijas k̦īmijterapija ar sekojošu fluoropirimidīnu uzturošo terapiju ir tikpat efektīva un mazāk toksiska (de Gramont et al., 2008). Līdzīgi rezultāti pētījumos ar irinotekānu saturošu terapiju - laiks līdz progresijai intermitējošu terapiju saṇēmušiem pacientiem ( 2 mēnešus saṇem k̦īmijterapiju, tad 2 mēnešus nesan,em, tad atkal saṇem, utt.) neatšḳīās no pacientiem, kas saṇēma terapiju bez pārtraukumiem (Labianca et al., 2011).

Pirmās līnijas paliatīvajā kī̄mijterapijā pacientam ar metastātisku nerezecējamu kolorektālo vēzi tiek rekomendētas fluoropirimidīnu (5-FU/LV, kapecitabīns), oksaliplatīnu (FOLFOX, CapeOx, FOLFOXIRI) vai irinotekānu (FOLFIRI) saturošās shēmas, kombinējot tās ar bioloğisko mērḳa terapiju (bevacizumabs, cetuksimabs, panitumumabs).

Pacientiem, kuri nav piemēroti agresīvai k,īmijterapijai vispārējā stāvokḷa dēl, var tikt izmantota 5-FU vai kapecitabīna terapija ar vai bez bevacizumaba pievienošanas. Bevacizumaba pievienošana 5-FU/LV statistiski ticami pagarina laiku līdz progresijai (8,8 vs 5,6 mēneši, $\mathrm{p}=0,0001)$ un kopējo dzīvildzi $(17,9$ vs 14,6 mēneši, $\mathrm{p}=0,008)$, (Kabbinavar et al., 2005).

\subsubsection{Citotoksiskie medikamenti}

Oksaliplatīns ir platīnu grupas medikaments, kas inhibē DNS replikāciju un inducē apoptozi un šūnu nāvi (Funke et al., 2008). Vairākos pētījumos ir apstiprināts oksaliplatīnu saturošās ḳīmijterapijas efektivitātes pārākums salīdzinājumā ar 5-FU/LV terapiju (1.2. tabula). De Gramont et al. 2007.gada pētījumā pacientiem, kuri saņēma FOLFOX, tika panākta ilgstošāka bezprogresijas (9,0 vs 6,2 mēneši, p = 0,0003) un kopējā dzīvildze (16,2 vs 14,7 mēneši, $\mathrm{p}=0,12)$. Līdzīgi kā FOLFOX, arī citas oksaliplatīnu saturošās shēmas ir efektīvākas par fluoropirimidīnu terapiju (Grothey et al., 2002; Giacchetti et al., 2000; Seymour et al., 2007; Goldberg et al,, 2004). 
Oksaliplatīna efektivitāte mKRV pirmās līnijas terapijā

\begin{tabular}{|l|c|c|c|}
\hline Izdzivotība & Ox + 5FU & $\mathbf{5 F U}$ & $\mathbf{p}$ \\
\hline $\begin{array}{l}\text { mPFS, mēneši (De Gramont et al., } \\
\text { 2000) }\end{array}$ & 9,0 & 6,2 & 0,0003 \\
\hline mOS, mēneši (De Gramont et al., 2000) & 16,2 & 14,7 & 0,12 \\
\hline mPFS, mēneši (Giacchetti et al, 2000) & 8,7 & 6,1 & 0,048 \\
\hline mOS, mēneši (Giacchetti et al, 2000) & 19,4 & 19,9 & $\mathrm{~ns}$ \\
\hline mPFS, mēneši (Seymour et al., 2007) & 8,8 & 6,3 & $<0,001$ \\
\hline mOS, mēneši (Seymour et al., 2007) & 15,0 & 13,7 & 0,608 \\
\hline
\end{tabular}

Ox - Oksaliplatīns, 5FU - 5-Fluorouracils, ns - not significant (nav statistiskās ticamības), mPFS - vidējā bezprogresijas izdzīvotība, mOS - vidējā kopējā izdzīvotība

Apmēram pusei pacientu FOLFOX terapija ir efektīva un audzējs samazinās (pozitīva audzēja radiologíiskā atbildes reakcija). EORTC III fāzes pētījumā, kurā tika novērtēta FOLFOX efektivitāte pacientiem ar rezektablām metastāzēm perioperatīvajā etapā, metastāžu samazināšanās tika novērota 40 \% pacientu (Nordlinger et al., 2008).

Oksaliplatīna saturošā kīmijterapijas viena no biežākajām blakusparādībām ir perifērā sensorā neiropātija. OPTIMOX1 pētījumā aprakstīta oksaliplatīna atcelšana uz laiku vai pilnīga pārtraukšana, turpinot pārējo medikamentu ievadi (5-FU, leikovorīna), kas būtiski neietekmē dzīvildzi, bet uzlabo dzīves kvalitāti (Nordlinger et al., 2008).

Uz OTIMOX1 pētījuma rezultātiem balstīts nākamais OPTIMOX2 pētījums, kurā tika izvērtēta uzturošās fluoropirimidīnu (5-FU/LV) terapijas efektivitāte pēc FOLFOX terapijas pārtraukšanas. Rezultāti liecināja, ka uzturošo terapiju saṇēmušiem pacientiem kopējā dzīvildze netika statistiski ticami pagarināta, salīdzinot ar pacientiem, kas uzturošo terapiju nesaṇēma (23,8 vs 19,5 mēneši, $\mathrm{p}=$ 0,42), bet laiks līdz progresijai bija atškirīīgs - 13,1 mēnesis uzturošās terapijas grupā un 9,2 mēneši novērošanas grupā ( $\mathrm{p}=$ 0,046), (Chibaudel et al., 2009).

5-FU vietā var izmantot arī perorālos fluoropirimidīnus. Kapecitabīna un oksaliplatīna saturošās kīmijterapijas (CapeOx jeb XELOX) efektivitāte ir līdzvērtīga FOLFOX efektivitātei - vidējais laiks līdz progresijai pacientiem, kas saṇem CapeOx ir 8,0 mēneši, bet pacientiem, kas saṇem FOLFOX - 8,5 mēneši (1.3. tabula), (Cassidy et al., 2008).

1.3. tabula

XELOX un FOLFOX salīdzinājums pirmās līnijas terapijā

\begin{tabular}{|l|c|c|}
\hline Izdzīvotība & XELOX (CapeOx) & FOLFOX \\
\hline mPFS, mēneši (Cassidy et al., 2008) & 8,0 & 8,5 \\
\hline mOS, mēneši (Cassidy et al., 2008) & 19,8 & 19,6 \\
\hline mPFS, mēneši (Ducreux et al., 2011) & 8,8 & 9,3 \\
\hline mOS, mēneši (Ducreux et al., 2011) & 19,9 & 20,5 \\
\hline
\end{tabular}

XELOX (CapeOx) - kapecitabīns, oksaliplatīns, leikovorīns, FOLFOX - oksaliplatīns, 5-FU, leikovorīns, mPFS - vidējā bezprogresijas izdzīvotība, mOS - vidējā kopējā izdzīvotība 
Bevacizumaba pievienošana oksaliplatīnu saturošai pirmās līnijas k,īmijterapijai (FOLFOX, CapeOx) pagarina laiku līdz progresijai, bet statistiski ticami neietekmē kopējo dzīvildzi. Pacientiem, kas saṇem bevacizumabu, laiks līdz progresijai ir 9,4 mēneši, bet pacientiem, kuri san,em tikai k̦īmijterapiju - 8,0 mēneši ( $\mathrm{p}=$ 0,0023) (Saltz et al., 2013).

Otrs biežāk izmantotais citostātiskais medikaments metastātiska kolorektālā vēža k̦īmijterapijā ir irinotekāns. Irinotekāns ir topoizomerāzes 1 ihibitors, kas ietekmē DNS replikāciju. Irinotekāna pievienošana fluoropirimidīnu terapijai metastātiska kolorektālā vēža ārstēšanā pagarina pacientu dzīvildzi (Seymour et al., 2007; Douillard et al., 2000; Kohne et al., 2003; Saltz et al., 2000; ,Goldberg et al., 2004).

Irinotekānu saturoša k,īmijterapija efektivitātes ziṇā tiek pielīdzināta oksaliplatīnu saturošai ķīmijterapijai. Pētījumi rāda, ka efektivitāte pirmās līnijas terapijā šiem medikamentiem ir līdzīga un dz̄̄vildzes dati būtiski neatškiras. Tournigand et al. 2004.gada pētījumā laiks līdz progresijai pacientiem FOLFOX grupā bija 8,0 mēneši, bet FOLFIRI grupā - 8,5 mēneši $(\mathrm{p}=0,26)$. Nākamais pētījums tikai apstiprināja iepriekšējā pētījuma rezultātu kopējā dzīvildze, laiks līdz progresijai un 3., 4. pakāpes toksicitātes biežums statistiski neatšḳīās pacientiem, kuri saṇēma FOLFOX vai FOLFIRI (Colluci et al., 2005), (1.4. tabula).

Jāatzīmēe ka medikamentu kombinācijai, ievades laikam un režīmam ir nozīmīga ietekme uz terapijas efektivitāti. Goldberg et al. 2004.gada pētījumā salīdzināta FOLFOX un irinotekānu saturošas k,īmijterapijas shēmas IFL efektivitāte. Iegūtie dati liecina, ka pacientiem FOLFOX grupā panākta ilgstošāka bezprogresijas dzīvildze (8,7 vs 6,9 mēneši, p = 0,0014) un vidējā dzīvildze (19,5 vs 15,0 mēneši, $\mathrm{p}=0,0001)$. Šajā pētījumā izmantotā IFL shēma atškiras no FOLFIRI ar 5-FU un LV devām un ievades ilgumu.

FOLFOX un FOLFIRI salīdzinājums pirmās līnijas terapijā

1.4. tabula

\begin{tabular}{|l|c|c|c|}
\hline Izdzīvotība & FOLFOX & FOLFIRI & p \\
\hline mPFS, mēneši (Tournigand et al., 2004) & 8,0 & 8,5 & 0,26 \\
\hline mOS, mēneši (Tournigand et al., 2004) & 20,6 & 21,5 & 0,99 \\
\hline mPFS, mēneši (Colluci et al., 2005) & 7,0 & 7,0 & $\mathrm{~ns}$ \\
\hline mOS, mēneši (Colluci et al., 2005) & 15,0 & 14,0 & $\mathrm{~ns}$ \\
\hline mPFS, mēneši (Seymour et al., 2004) & 8,8 & 8,6 & $\mathrm{~ns}$ \\
\hline mOS, mēneši (Seymour et al., 2004) & 15,0 & 16,2 & $\mathrm{~ns}$ \\
\hline
\end{tabular}

FOLFOX - oksaliplatīns, 5-FU, leikovorīns, FOLFIRI - irinotekāns, 5-FU, leikovorīns, ns - not significant (nav statistiskās ticamības), mPFS - vidējā bezprogresijas izdzīvotība, mOS - vidējā kopējā izdzīvotība

Biežākās irinotekāna toksiskās blakusparādības ir caureja, dehidratācija, neitropēnija. Pacientiem ar urīdīna-difosfāta-glikouronoziltransferāzes $1 A l$ gēna polimorfismu ir samazināta irinotekāna aktīvo metabolītu inaktivēšana, līdz ar to toksiskās izpausmes tiek novērotas biežāk (Innocenti et al., 2004). Rezultāti no Sobrero et al. IV fāzes pētījuma liecina, ka anti-VEGF 
monoklonālās antivielas bevacizumaba lietošana ar FOLFIRI ir efektīva un var tikt izmantota pirmās līnijas terapijā. Pētījumā novērotais vidējais laiks līdz progresijai ir 11,1 mēneši, kas ir līdzvērtīgs fluoropirimidīnu un bevacizumaba terapijas efektivitātei (Sobrero et al., 2009).

Pacientiem ar KRASwt metastātisku kolorektālo vēzi FOLFIRI terapijai var tikt pievienoti EGFR inhibitori cetuksimabs vai panitumumabs. Cetuksimaba pievienošana ķīmijterapijai būtiski pagarina bezprogresijas izdzīvotību $(9,9$ vs 8,4 mēneši, $\mathrm{p}=0,0012)$ un kopējo izdzīvotību (23,5 vs 20,0 mēneši, p = 0,0093) (Van Cutsem et al., 2010).

Tā kā citotoksisko medikamentu kombinācijas nespēj būtiski pagarināt dzīvildzi, nepārtraukti tiek meklētas jaunas medikamentu kombinācijas. Viena no pirmās līnijas terapijas iespējām ir oksaliplatīnu un irinotekānu saturoša terapija FOLFOXIRI. Falcone et al. dati liecina, ka pacientiem, kas saņem FOLFOXIRI, salīdzinot ar tiem, kas sanem FOLFIRI, ir garāks bezprogresijas intervāls $(9,8$ vs 6,9 mēneši, $\mathrm{p}=0,0006)$ un vidējā dzīvildze $(22,6$ vs 16,7 mēneši, $\mathrm{p}=0,032),(1.5$. tabula). Tomēr FOLFOXIRI terapija ir saistīta ar biežāku un nopietnāku toksicitāti (neirotoksicitāte, neitropēnija), (Falcone et al., 2007).

FOLFIRI un FOLFOXIRI salīdzinājums pirmās līnijas terapijā

1.5. tabula

\begin{tabular}{|l|c|c|c|}
\hline Izdzivotība & FOLFIRI & FOLFOXIRI & p \\
\hline mPFS, mēneši (Falcone et al., 2007) & 6,9 & 9,8 & 0,0006 \\
\hline mOS, mēneši (Falcone et al., 2007) & 16,7 & 22,6 & 0,032 \\
\hline mPFS, mēneši (Souglakos et al., 2006) & 6,9 & 8,4 & 0,17 \\
\hline mOS, mēneši (Souglakos et al., 2006) & 19,5 & 21,5 & 0,337 \\
\hline
\end{tabular}

FOLFIRI - irinotekāns, 5-FU, leikovorīns, FOLFOXIRI - irinotekāns, oksaliplatīns, 5FU, leikovorīns, mPFS - vidējā bezprogresijas izdzīvotība, mOS - vidējā kopējā izdzīvotība

Visjaunākais citotoksiskais medikaments mKRV ārstēšanā ir Trifluridīns/Tipiracils (TAS-102), kas tika reǵistrēts Eiropā 2017. gadā. Tas ir perorāls medikaments, kas satur citotoksisko timidīna anologu trifluridīnu un timidīna fosforilāzes inhibitoru - tipiracila hidrohlorīdu, kas kavē trifluridīna degradēšanu. Medikamenta efektivitāte apstiprināta RECOURSE pētījumā pacientiem ar refraktāru mKRV, kas ir saṇēmuši vismaz divas iepriekšējās k,īmijterapijas līnijas ar oksliplatīnu, irinotekānu, ani-EGFR inhibitoriem un angioǵenēzes inhibitoriem (Mayer et al., 2015). Tika iegūts gan kopējās izdz̄ivotības $(7,1$ vs 5,3 mēn), gan bezprogresijas izdzīvotības (2,0 vs 1,7 mēn) ieguvums, salīdzinot ar placebo. Ar trifluridīnu/tipiracilu ārstētie pacienti sasniedza ilgstošāku slimības kontroli un stabilizāciju: (44 \% salīdzinājumā ar $16 \%$, p < 0,01) un šie pacienti ilgāk bija apmierinošā vispārējā stāvoklī, kas liecina par labākas dz̄̄ves kvalitātes saglabāšanu.

Biežākās medikamenta blaknes bija leikopēnija, neitropēnija, anēmija un trombocitopēnija, pārsvarā asimptomātiskas un korig̣ējamas ar standartterapiju. Terapijas 
pārtraukšanas rādītājs bija zems: 3,6 \% salīdzinājumā ar 1,5\% placebo grupā (Mayer et al., 2015).

\subsubsection{Mērķa (bioloğiskā) terapija}

Bevacizumabs ir humanizēta monoklonāla antiviela, kas bloḳē vaskulārā endoteliālā augšanas faktora (VEGF) aktivitāti, ietekmējot audzēja angioǵenēzi un palielinot citotoksisko medikamentu aktivitāti. Pētījumu rezultāti liecina, ka bevacizumaba pievienošana pirmās līnijas k̦īmijterapijai statistiski nozīmīgi pagarina dzīvildzi pacientiem ar nerezecējamu metastātisku kolorektālo vēzi (Saltz et al., 2008; Sobrero et al., 2009; Kabbinavar et al., 2005). Tomēr ir arī pretrun̄̄gi dati, kas liecina par to, ka bevacizumaba pievienošana oksaliplatīnu saturošai kīmijterapijai neietekmē audzēja radioloğisko atbildes reakciju (Saltz et al., 2008). Šie rezultāti ir būtiski gadījumos, kad tiek izvēlēta terapijas taktika pacientiem ar rezecējamu metastātisku kolorektālo vēzi, kad ir īpaši svarīga maksimāla metastāžu samazināšanās preoperatīvajā etapā.

Bevacizumabs nav efektīvs adjuvantajā terapijā pacientiem ar II un III stadijas radikāli operētu resnās zarnas vēzi (Choti et al., 2009; Allegra et al., 2011). Nav arī pārliecinošu datu par bevacizumaba efektivitāti pacientiem ar IV stadijas kolorektālo vēzi pēc radikālas metastāžu rezekcijas; tādēḷ šai pacientu grupai anti-VEGF monoklonālās antivielas lietošana nav pamatota.

Citā pētījumā ir novērota saistība starp bevacizumaba terapiju un audzēja patoloǵisko atbildes reakciju. Blazer et al. 2008. gadā analizēja patoloğisko audzēja atbildes reakciju pacientiem ar operētu metastātisku kolorektālo vēzi pēc k̄īmijterapijas, un rezultāti liecināja, ka pilna patoloğiska remisija (visu l,aundabīgo šūnu bojāeja, nekroze) biežāk tiek panākta pacientiem, kas sanem bevacizumabu.

Bevacizumaba terapijas laik̄̄ ir paaugstināts arteriālās trombembolijas, smadzeṇu infarkta, gastrointestinālās perforācijas risks, pasliktinās brūču dz̄ī̌ana (Hochster et al., 2008; Scappaticci et al., 2005), bet nepaaugstina venozās trombembolijas risku (Ranpura et al., 2011). Gastrointestinālās perforācijas risks pieaug pacientiem pēc plašām abdominālām kirurğiskām operācijām, vēderplēves rezekcijas, bet to neietekmē primārā tumora lokalizācijas vieta (Cannistra et al., 2007). Pētījumu metaanalīze liecina, ka bevacizumaba pievienošana kīmijterapijai paaugstina ar terapiju saistīto mirstību $(\mathrm{p}=0,04)$, asiņošanas, neitropēnijas un gastrointestinālās perforācijas risku (Ranpura et al., 2011). Pacientiem, kas san̄ēma bevacizumabu pirmsoperācijas etapā, biežāk tika novērotas brūču komplikācijas (Scappaticci et al., 2005). Pasliktinātu brūču dzī̌sanu novēro pacientiem pēc plašām abdominālām operācijām, ka arī pacientiem, kuriem bevacizumaba terapija nav tikusi pārtraukta 
perioperatīvajā etapā. Savukārt pacientiem, kuriem bevacizumaba terapija tika pārtraukta 6 nedēlas pirms operācijas, brūču komplikāciju risks nepieauga. Pētījumi apstiprina faktu, ka brūču komplikāciju risks nepaaugstinās, ja starp bevacizumaba terapijas pabeigšanu un ķirurğ́isku operāciju ir ievērots laika intervāls 5 līdz 8 nedēlas (Grunberger et al., 2008; Reddy et al., 2008).

Angioǵenēzes inhibitors ziv-aflibercepts ir VEGF receptora rekombinants proteīns, kas piesaista VEGF un neḷauj tam saistīties ar VEGF receptora ekstracelulāro daḷu. Rezultātā tiek inhibēta angioǵenēze. Medikamenta efektivitāte ir apstiprināta VELOUR pētījumā pacientiem ar refraktāru mKRV - kopējās izdzīvotības ieguvums, kombinējot ziv-afliberceptu ar FOLFIRI terapiju, bija tikai 1,4 mēneši (Van Cutsem et al., 2011). Angioǵenēzes inhibitors ramucirumabs ir humanizēta monoklonāla antiviela, kas piesaistās VEGF receptora ekstracelulārajam domēnam un pārtrauc signālu pārvadi. Medikamenta efektivitāte ir apstiprināta pacientiem ar mKRV, kas iepriekš saṇēmuši fluoropirimidīnu, oksaliplatīna un bevacizumaba kombinēto terapiju RAISE pētījumā. Bezprogresijas izdzīvotība un kopējā izdzīvotība ramucirumab grupā, salīdzinot ar placebo, bija attiecīgi 5,7 vs 4,5 mēneši un 13,3 vs 11,7 mēneši (Langer et al., 2008).

Otra klīniski nozīmīga mērḳa terapijas grupa ir anti-EGFR monoklonālās antivielas. Cetuksimabs ir himēriska, bet panitumumabs - humanizēta monoklonāla antiviela, abi šie biolog̣iskie ağenti piesaistās EGFR (epiteliālā augšanas faktora receptoram) un inhibē RAS/RAF/MAPK signālu pārvades ceḷus. Cetuksimabs un panitumumabs ir pētīti gan pirmās līnijas terapijā ar FOLFOX (Douillard et al., 2010; Bokemeyer et al., 2009) vai FOLFIRI (Van Cutsem et al., 2009; Kohne et al., 2010), gan arī nākamās līnijās pacientiem ar metastātisku kolorektālu vēzi. Veicot sīkāku pacientu grupu analīzi, vairākos pētījumos ir atklāta saistība starp KRAS gēna 12. un 13. kodona izmain̄ām un EGFR inhibitoru efektivitāti (Bokemeyer et al., 2009; Van Cutsem et al., 2009; Lievre et al., 2008; Karapetis et al., 2008; Amado et al., 2008). Pacientiem ar KRAS mutāciju cetuksimaba vai panitumumaba terapija nav efektīva, bet pacientiem, kuriem mutācija netiek konstatēta (KRASwt), mērḳa terapijas pievienošana ķīmijterapijai būtiski uzlabo bezprogresijas un kopējo dzīvildzi.

Tomēr KRASwt stāvoklis negarantē EGFR inhibitoru efektivitāti, jo ir iespējamas mutācijas citos gēnos, kas var izraisīt rezistenci pret cetuksimabu vai panitumumabu. De Rock et al. 2010.gada retrospektīvajā analīzē aprakstīja, ka pacientiem ar neizmainītu $K R A S$ stāvokli, bet noteiktu mutāciju $B R A F, N R A S$ vai $P I K 3 C A$ gēnos, ir samazināta audzēja atbildes reakcija uz cetuksimabu terapiju. Šos rezultātus apstiprināja arī sekojošie publicēto EGFR inhibitoru pētījumu rezultāti - PRIME pētījumā $17 \%$ pacientu ar KRASwt konstatēta mutācija citā KRAS kodonā vai NRAS (Douillard et al., 2013), bet 9 pētījumu metaanalīzē konstatēta nozīmīga 
bezprogresijas un kopējās izdzīvotības atšķirība pacientiem ar RASwt (Sorich et al., 2015). Sakarā ar to, ka pacientiem ar $K R A S, N R A S$ vai $B R A F$ mutāciju cetuksimaba vai panitumumaba terapija ir neefektīva, NCCN, ESMO un ASCO vadlīnijās tiek rekomendēta $R A S$ genotipēšana vēža audos visiem pacientiem, kuriem tiek plānota kombinēta terapija (Allegra et al., 2009, Van Cutsem et al., 2016; NCCN, 2019), lai izvairītos no toksiskām blakusparādībām un ārstēšanās izmaksu pieauguma.

Biežākās EGFR inhibitoru toksiskās izpausmes ir ādas izsitumi (Lievre et al., 2008; Berlin et al., 2007), alerğiskas reakcijas, anafilakse (Resch et al., 2011). Turklāt ādas toksicitāte ir saistīta ar EGFR inhibitoru efektivitāti - jo izteiktāki ir ādas bojājumi, jo labāki ārstēšanās rezultāti (Berlin et al., 2007).

Cetuksimaba un FOLFIRI efektivitāte ir apstiprināta randomizētā CRISTAL pētījumā (Van Cutsem et al., 2009). Pacientiem ar neizmainītu KRAS gēnu, kas san̄ēma cetuksimabu un FOLFIRI, bija statistiski ticami labāka audzēja atbildes reakcija $(59,3$ vs 43,2 \%, p = 0,0025) un laiks līdz progresijai (9,9 vs 8,7 mēneši, $\mathrm{p}=0,02)$, salīdzinot ar tiem, kas san̄ēma tikai FOLFIRI. 2011. gadā publicēta papildināta CRISTAL pētījuma datu analīze, kur pacientiem bez KRAS mutācijas, kas papildus ḳīmijterapijai saṇema cetuksimabu, tika novērota statistiski ticami labāka audzēja atbildes reakcija $(57,3$ vs 39,7 \%,p < 0,001), bezprogresijas dzīvildze (9,9 vs 8,4 mēneši, $\mathrm{p}=0$ 0,0012) un kopējā dzivildze $(23,5$ vs 20,0 mēneši, $\mathrm{p}=0,0093)$, (Van Cutsem et al., 2011). 2015. gadā prezentēti dati no papildu RAS gēnu analīzes; tiek rekomendēta RAS testēšana visiem pacientiem pirms ārstēšanas uzsākšanas (Van Cutsem et al., 2015).

Bokemeyer et al., 2008.gada pētījums parāda, ka cetuksimabs uzlabo audzēja atbildes reakciju un laiku līdz progresijai arī kombinācijā ar FOLFOX pacientiem ar neizmainītu KRAS OPUS pētījumā. Pacientiem, kas san̄ēma cetuksimabu un FOLFOX, bija statistiski ticami labāka audzēja atbildes reakcija $(60,7$ vs 37,0 \%, p =0,011) un laiks līdz progresijai $(7,7$ vs 7,2 mēneši, $\mathrm{p}=$ 0,016), salīdzinot ar tiem, kas saṇēma tikai FOLFOX. 2010. gadā Bokemeyer et al prezentēja papildu OPUS pētījuma analīzi, kurā laiks līdz progresijai būtiski atškīrās pacientiem, kas saṇēma monoklonālo antivielu un FOLFOX $(8,3$ vs 7,2 mēneši, $\mathrm{p}=0,0064)$. Analizējot pacientus ar KRAS mutāciju, iegūtie rezultāti liecināja, ka cetuksimaba pievienošana k̦īmijterapijai saīsināja laiku līdz progresijai $(\mathrm{p}=0,0153)$ un samazināja audzēja atbildes reakciju ( $\mathrm{p}=0,0290)$, (Bokemeyer et al., 2010). Tālākās $R A S$ gēnu saimes analīzes rezultāti prezentēti 2014. gada ASCO konferencē, kas apstiprināja pilnas RAS testēšanas nepieciešamību mKRV pacientiem (Bokemeyer et al., 2014).

Panitumumabs, humanizētas anti-EGFR monoklonālās antivielas, un FOLFOX efektivitāte pirmās līnijas metastātiska kolorektālā vēža ārstēšanā, tika pierādīta PRIME pētījumā (Douillard et al., 2011). Pacientiem ar neizmain̄itu KRAS gēnu, kas saṇēma 
panitumumabu un FOLFOX, bija statistiski ticami garāka bezprogresijas dzīvildze $(10,0$ vs 8,6 mēneši, $\mathrm{p}=0,009$ ), salīdzinot ar tiem, kas saņēma tikai FOLFOX, bet statistiski ticams kopējās dzīvildzes ieguvums netika pierādīts. Arī sekojošajā papildu datu analīzē apstiprinājās cetuksimaba efektivitāte pacientiem ar RASwt mKRV (Douillard et al., 2013).

Parādoties klīniskajā praksē jauniem medikamentiem, tiek pētīta vairāku bioloğisko medikamentu kombinētās terapijas efektivitāte. PACCE pētījumā tika pierādīts, ka panitumumaba pievienošana terapijas kombinācijai, kas satur bevacizumabu un oksaliplatīnu vai irinotekānu saturošu ḳ̄mijterapiju, palielina toksicitāti un samazina dzīvildzi (Hecht et al., 2008). Līdzīgi dati tika iegūti CAIRO pētījumā, kurā cetuksimaba, līdzīgi kā iepriekšèjā pētījumā panitumumaba, pievienošana bevacizumabu un oksaliplatīnu saturošai terapijai tikai pasliktināja pacientu dz̄ives kvalitāti un saīsināja laiku līdz progresijai ( $\mathrm{p}=0,01)$, (Tol et al., 2009).

Pacientiem ar mKRV BRAFV600E mutāciju audzēja šūnās tiek pētīta $B R A F$ inhibitoru (vemurafeniba, dabrafeniba, encorafeniba) un MEK inhibitoru (trametiniba, binimetiniba) efektivitāte - atbildes reakcija uz terapiju ir 26-48 \% (Kopetz et al., 2019; Van Cutsem et al., 2019).

Pacientiem ar HER2 pozitīvu mKRV ir apstiprināta anti-HER2 medikamentu lietošana otrajā un turpmākajās līnijās. Trastuzumaba/pertuzumaba un trastuzumaba/lapatiniba duālā HER2 receptora blokādes efektivitāte mKRV pacientiem ir 30-32 \% (Meric-Bernstam et al., 2019; Sartore-Bianchi et al., 2016).

PD-1 inhibitoru (pembrolizumaba, nivolumaba) terapija ir efektīva pacientiem ar mKRV un augstu mikrosatelītu nestabilitāti (MSI-H/dMMR) un var tikt pielietota gan pirmajā, gan nākamajās terapijas līnijās. Audzēja atbildes reakcija, saņemot pirmās līnijas anti-PD1 terapiju, sasniedz $60 \%$, bet saņemot otrās līnijas terapiju, tā sasniedz 40-55\% pacientiem ar MSI-H/dMMR mKRV (Lenz et al., 2019; Le et al., 2015; Overman et al., 2017).

Regorafenibs, multikināžu inhibitors (VEGF, FGFR, BRAF, KIT un RET kināžu inhibitors) pētīts mKRV vēža pacientiem, kas ir progresējuši pēc saṇemtās standarta terapijas CORRECT (Grothey et al., 2013) un CONCUR (Li et al,, 2015) pētījumā. Pētījumi uzrādīja nelielu statistiski ticamu bezprogresijas un kopējās izdzīvotības ieguvumu, kā arī izteiktu ādas un gastrointestinālo toksicitāti. CORRECT pētījumā kopējās izdzīvotības ieguvums bija 1,4 mēneši, bet bezprogresijas izdzīvotības ieguvums - tikai 0,2 mēneši.

0,2-1\% mKRV pacientu ir konstatēta NTRK gēna translokācija, kas aktivizē MAPK un PI3K/AKT signālu pārvades ceḷu ar sekojošu šūnu proliferāciju, invāziju un angioğenēzi. NTRK inhibitori larotrectinibu un entrectinibu ir pētīti nelielos I/II fāzes pētījumos un uzrāda daudzsološus rezultātus pacientiem ar NTRK translokāciju (Okamura et al., 2018). 


\subsection{5. Ķīmijterapijas un mērķa terapijas secība metastātiska kolorektālā vēža ārstēšanā}

Nerezecējama mKRV pacienta ārstēšanas plāns parasti ir sekojošs (ESMO, 2016):

1. Pirmās līnijas kīmijterapija 4-6 mēnešus (fluoropirimidīnu un oksaliplatīna kombinācija ar vai bez mērḳa terapijas).

2. Novērošana vai uzturošā terapija 6-8 mēnešus.

3. Pirmās līnijas atsākšana vai otrās līnijas k̦īmijterapija (progresijas gadījumā).

4. Otrās līnijas ķīmijterapija 5-7 mēnešus (fluoropirimidīni, irinotekāns, mērķa terapija).

5. Pārtraukums pirms trešās līnijas ķīmijterapijas.

6. Trešās līnijas ķīmijterapija 3-4 mēnešus (trifluridīns/tipiracils, mērķa terapija).

7. Ceturtās līnijas ķīmijterapija atsevišķos gadījumos - dažus mēnešus.

8. Paliatīvā aprūpe.

Šì terapijas nepārtrauktības pieeja ir balstīta starptautiskajās vadlīnijās. Metastātiska resnās zarnas vēža ārstēšanas ESMO vadlīnijas shematiski ir attēlotas 1.6. tabulā. Medikamentu un ārstēšanas shēmu izvēli nosaka gan pacienta vispārējais stāvoklis un blakussaslimšanas, gan audzēja biolog̣ija (mutācija kādā no RAS saimes gēniem, metastāžu lokalizācija un daudzums, audzēja agresivitāte un augšanas ātrums), gan paredzamā toksicitāte un tās ietekme uz dzīves kvalitāti. Pacients ar metastātisku resnās zarnas vēzi, saṇemot vairāku līniju ḳimijterapiju, var nodzīvot vidēji 30 mēnešus (ESMO, 2016).

Sistēmiskās terapijas izvēle pacientiem ar nerezecējamu metastātisku kolorektālo vēzi

1.6. tabula (2016. g. ESMO vadlīnijas, pielāgots Cīrihes algoritms)

\begin{tabular}{|l|l|l|}
\hline \multicolumn{2}{|c|}{ Audzēja molekulārais tips } \\
\hline Negatĩva $\boldsymbol{R} \boldsymbol{A S}$ mutācija & Pozitīva $\boldsymbol{R} \boldsymbol{A S}$ mutācija & Pozitīva BRAF mutācija \\
\hline Pirmā līnija & $\begin{array}{l}\text { FOLFOX vai FOLFIRI ar } \\
\text { bevacizumabu }\end{array}$ & $\begin{array}{l}\text { FOLFOXIRI ar } \\
\text { bevacizumabu }\end{array}$ \\
\hline $\begin{array}{l}\text { FOLFOX vai FOLFIRI ar EGFR } \\
\text { inhibitoriem } \\
\text { vai }\end{array}$ & $\begin{array}{l}\text { FOLFOX vai FOLFIRI ar } \\
\text { bevacizumabu }\end{array}$ & $\begin{array}{l}\text { FP ar bevacizumabu } \\
\text { vai } \\
\text { Uzturošā terapija }\end{array}$ \\
\hline $\begin{array}{l}\text { FP ar bevacizumabuana } \\
\text { vai } \\
\text { novērošana }\end{array}$ & $\begin{array}{l}\text { FP ar bevacizumabu } \\
\text { vai } \\
\text { novērošana }\end{array}$ \\
\hline
\end{tabular}


1.6. tabulas turpinājums

\begin{tabular}{|c|c|c|}
\hline \multicolumn{3}{|c|}{ Audzēja molekulārais tips } \\
\hline Negatīva $R A S$ mutācija & Pozitīva $R A S$ mutācija & Pozitīva $B R A F$ mutācija \\
\hline \multicolumn{3}{|l|}{ Otrā līnija } \\
\hline $\begin{array}{l}\text { FOLFOX vai FOLFIRI ar EGFR } \\
\text { inhibitoriem } \\
\text { vai } \\
\text { Irinotekāns ar cetuksimabu } \\
\text { vai } \\
\text { EGFR inhibitori monoterapijā } \\
\text { vai } \\
\text { Trifluridīns/tipiracils } \\
\text { vai } \\
\text { Regorafenibs }\end{array}$ & $\begin{array}{l}\text { Trifluridīns/tipiracils } \\
\text { vai } \\
\text { Regorafenibs }\end{array}$ & $\begin{array}{l}\text { Trifluridīns/tipiracils } \\
\text { vai } \\
\text { Regorafenibs }\end{array}$ \\
\hline Trešā līnija & & \\
\hline $\begin{array}{l}\text { FOLFOX vai FOLFIRI ar EGFR } \\
\text { inhibitoriem } \\
\text { vai } \\
\text { Irinotekāns ar cetuximabu } \\
\text { vai } \\
\text { EGFR inhibitori monoterapijā } \\
\text { vai } \\
\text { Trifluridīns/tipiracils } \\
\text { vai } \\
\text { Regorafenibs }\end{array}$ & $\begin{array}{l}\text { Trifluridīns/tipiracils } \\
\text { vai } \\
\text { Regorafenibs }\end{array}$ & $\begin{array}{l}\text { Trifluridīns/tipiracils } \\
\text { vai } \\
\text { Regorafenibs }\end{array}$ \\
\hline
\end{tabular}

FOLFOX-oksaliplatīns, leukovorīns, 5-fluorouracils; FOLFIRI - irinotekāns, leukovorīns, 5-fluorouracils; FOLFOXIRI - oksaliplatīns, irinotekāns, leukovorīns, 5-fluorouracils; EGFR - epidermas augšanas faktora receptori; FP - fluoropirimidīni

\section{Pirmās līnijas terapija}

Pirmās līnijas terapijā vienlīdz efektīva ir gan oksaliplatīnu, gan irinotekānu saturoša ķīmijterapija. Salīdzinot FOLFIRI un FOLFOX terapijas rezultātus, būtiski neatšķiras audzēja atbildes reakcija (RR $54 \%$ un $56 \%$ ) un laiks līdz progresijai (8,4 un 8,0 mēneši), (Tournigand et al., 2004; Colucci et al., 2005), (1.8. tabula). Galvenā atškirība ir toksiskajās blakusparādībās: 3.-4. pakāpes gastrointestinālā toksicitāte (škebināšana, vemšana, caureja, mukozīts) un alopēcija ir sastopamas biežāk FOLFIRI terapijas laikāa, bet perifērā neiropātija un 3.-4. pakāpes neitropēnija biežāka FOLFOX terapijas laikā. Pacientiem, kuri nav piemēroti oksaliplatīna vai irinotekāna terapijai vispārējā stāvokḷa vai blakusslimību dēl, ir pieḷaujama fluoropirimidīnu monoterapija, kas ir vieglāk panesama, bet mazāk efektīva.

Angioğenēzes inhibitora bevacizumaba pievienošana pirmās līnijas ḳimijterapijai uzlabo dzīvildzes datus (Saltz et al., 2008; Hurwitz et al., 2004). Bevacizumaba pievienošana 5FU/LV vai kapecitabīna pirmās līnijas terapijai uzlabo gan bezprogresijas, gan kopējo izdzīvotību (Kabbinavar et al., 2005; Tebbutt et al., 2010), bet bevacizumaba pievienošana oksaliplatīnu saturošai terapijai (FOLFOX, CAPEOX) pagarina bezprogresijas, bet ne kopējo izdzīvotību NO16966 pētījumā (Saltz et al., 2008). Sešu randomizētu pētījumu metaanalīze 
apstiprina bevacizumaba efektivitāti pirmās līnijas terapijā - bezprogresijas izdzīvotība uzlabojās par 28 \%, bet kopējā izdzīvotība - par 16 \% (Macedo et al., 2012).

Divi jauni perorālie vaskulārā endotēlija augšanas faktora receptora-2 tirozīnkināzes inhibitori vatalanib un cediranib ir pētîti pirmās līnijas terapijā kopā ar oksaliplatīnu saturošu kī̄mijterapiju. Rezultāti neuzrādīja būtisku dz̄ivildzes ieguvumu vai audzēja atbildes reakciju (Hecht et al., 2011; Schmoll et al., 2010), tādēl, šo medikamentu lietošana pirmās līnijas terapijā nav pamatota.

Šobrīd, beidzoties bioloğisko medikamentu patentiem, gan ASV, gan Eiropā onkoloğisko medikamentu klāstā pieaug reǵistrēto biosimilaru daudzums. Šie medikamenti tiek lietoti atbilstoši starptautiskām vadlīnijām ar tādu pašu mērḳi kā oriğinālie medikamenti. ASV klīniskajā praksē tiek lietoti divi bevacizumaba biosimilari - bevacizumabs-awwb un bevacizumabs-bvzr.

Pacientiem ar RASwt audzēju antiepidermālā augšanas faktora cetuksimaba pievienošana pirmās līnijas terapijā pagarina laiku līdz progresijai (Bokemeyer et al., 2009; Hecht et al., 2011). Arī otra anti-EGFR monoklonālā antiviela - panitumumabs pirmās līnijas terapijā kopā ar oksaliplatīnu saturošu ḳīmijterapiju pagarina laiku līdz progresijai (Douillard et al., 2010). Medikamentu efektivitāte apstiprināta CRYSTAL (Van Cutsem et al., 2009; Van Cutsem et al., 2011, Van Cutsem et al., 2015), OPUS (Bokemeyer et al., 2009; Bokemeyer et al., 2010; Bokemeyer et al., 2014) un PRIME (Douillard et a.l, 2010; Douillard et al., 2011; Douillard et al., 2013) pētījumos (1.7. tabula). N,emot vērā, ka labās un kreisās puses mKRV prognoze un ārstēšanas efektivitāte atškiras, tika pētīta monoklonālo antivielu efektivitāte pacientiem ar atšḳirīgu primārā audzēja lokalizāciju. Ir pierādīts, ka labāki anti-EGFR monoklonālo antivielu ārstēšanas rezultāti ir mKRV RASwt pacientiem ar kreisās puses audzēju, bet mKRV RASwt pacientiem ar labās puses audzēju efektīvāka ir kombinēta terapija ar bevacizumabu (Wang et al., 2015; Arnold et al., 2017). Š̄̄ atrade ir saistāma ar atškirīīgiem audzēju molekulāri ğenētiskajiem veidiem, atkarībā no to lokalizācijas.

PD-1 inhibitoru (pembrolizumaba, nivolumaba) terapija ir efektīva pacientiem ar mKRV un augstu mikrosatelītu nestabilitāti (MSI-H/dMMR) un var tikt pielietota pirmajā terapijas līnijā šai pacientu grupai, kas nav piemēroti standarta terapijai ar FOLFOX/FOLFIRI un monoklonālajām antivielām (Lenz et al., 2019). 
1.7. tabula

Monoklonālo antivielu (angiogenēzes un EGFR inhibitoru) pētījumi pirmās līnijas terapijā pacientiem ar nerezecējamu mKRV (Chibaudel et al., 2012)

\begin{tabular}{|c|c|c|c|c|c|}
\hline Pētījumi & Pētāmie medikamenti & $\begin{array}{l}\text { Pacientu } \\
\text { skaits }\end{array}$ & $\begin{array}{l}\text { Audzēja } \\
\text { atbildes } \\
\text { reakcija }(\%)\end{array}$ & $\begin{array}{l}\text { mPFS } \\
\text { (mēešni) }\end{array}$ & $\begin{array}{l}\text { mOS } \\
\text { (mēneši) }\end{array}$ \\
\hline \multicolumn{6}{|c|}{ Bevacizumaba pētījumi } \\
\hline $\begin{array}{l}\text { AVF } 2107 \mathrm{~g} \\
\text { (Hurwitz et al., } \\
\text { 2004) }\end{array}$ & $\begin{array}{l}\text { Irinotekāns/5FU/LV } \pm \\
\text { bevacizumabs }\end{array}$ & $67 / 85$ & $37 / 60(+23 \%)$ & $\begin{array}{l}7,4 / 13,5 \\
(\text { HR } 0,44)\end{array}$ & $\begin{array}{l}17,6 / 22,7 \\
\text { (HR } 0,58)\end{array}$ \\
\hline $\begin{array}{l}\text { CAIRO2 (Tol et } \\
\text { al., 2009) }\end{array}$ & $\begin{array}{l}\text { XELOX + } \\
\text { bevacizumabs }\end{array}$ & 156 & 50 & 10,6 & 22,4 \\
\hline \multicolumn{6}{|c|}{ EGFR inhibitoru pētījumi } \\
\hline $\begin{array}{l}\text { CRYSTAL (Van } \\
\text { Cutsem et al., } \\
\text { 2009) }\end{array}$ & $\begin{array}{l}\text { FOLFIRI } \pm \\
\text { cetuksimabs }\end{array}$ & $350 / 316$ & $40 / 57(+17 \%)$ & $\begin{array}{l}8,4 / 9,9 \\
(\mathrm{HR} 0,70)\end{array}$ & $\begin{array}{l}20,0 / 23,5 \\
(\text { HR } 0,80)\end{array}$ \\
\hline $\begin{array}{l}\text { OPUS (Bokemeyer } \\
\text { et al., 2009) }\end{array}$ & $\begin{array}{l}\text { FOLFOX } \pm \\
\text { cetuksimabs }\end{array}$ & $73 / 61$ & $37 / 61(+24 \%)$ & $\begin{array}{l}7,2 / 7,7 \\
(\text { HR } 0,57)\end{array}$ & $\begin{array}{l}18,5 / 22,8 \\
\text { (HR } 0,85)\end{array}$ \\
\hline $\begin{array}{l}\text { PRIME (Douillard } \\
\text { et al., 2010) }\end{array}$ & $\begin{array}{l}\text { FOLFOX } \pm \\
\text { panitumumabs }\end{array}$ & $331 / 325$ & $48 / 55(+7 \%)$ & $\begin{array}{l}8,0 / 9,6 \\
(\mathrm{HR} 0,80)\end{array}$ & $\begin{array}{l}19,7 / 23,9 \\
(\mathrm{HR} 0,83)\end{array}$ \\
\hline $\begin{array}{l}\text { COIN (Maughan et } \\
\text { al., 2011) }\end{array}$ & $\begin{array}{l}\text { Oksaliplatīnu saturoša } \\
\text { kīmijterapija } \pm \\
\text { cetuksimabs }\end{array}$ & $367 / 362$ & $57 / 64(+7 \%)$ & $\begin{array}{l}8,6 / 8,6 \\
(\text { HR } 0,96)\end{array}$ & $\begin{array}{l}17,9 / 17,0 \\
(\text { HR } 1,38)\end{array}$ \\
\hline $\begin{array}{l}\text { NORDIC VII } \\
\text { (Tveit et al., 2011) }\end{array}$ & FLOX \pm cetuksimabs & $97 / 97$ & $\begin{array}{l}47 / 46 \\
(-1 \%)\end{array}$ & $\begin{array}{l}8,7 / 7,9 \\
(\mathrm{HR} 1,07)\end{array}$ & $\begin{array}{l}22,0 / 20,1 \\
(\mathrm{HR} 1,14)\end{array}$ \\
\hline
\end{tabular}

FOLFOX - oksaliplatīns, 5-FU, leikovorīns, FOLFIRI - irinotekāns, 5-FU, leikovorīns, FLOX - oksaliplatīns, 5FU, leikovorīns, HR - hazard ratio (riska attiecība), mPFS - vidējā bezprogresijas izdzīvotība, mOS - vidējā kopējā izdzīvotīiba

\section{Otrās līnijas terapija}

Pēc tam, kad ir konstatēta progresija pēc pirmās līnijas terapijas saṇemšanas, lielākā daḷa pacientu ir piemēroti otrās līnijas terapijai. Pacientiem, kuri pirmās līnijas terapijā saṇēma oksaliplatīnu saturošu ķīmijterapiju, tiek rekomendēta irinotekānu saturoša k,īmijterapija. Audzēja atbildes reakcija pēc otrās līnijas FOLFIRI terapijas ir 4-12\%, bet laiks līdz progresijai 2,5-4,7 mēneši (Tournigand et al., 2004; Van Cutsem et al., 2011; Peeters et al., 2010). Atsevišķos nerandomizētos otrās līnijas FOLFIRI pētījumos ir novērota pozitīva audzēja atbildes reakcija līdz 20-25\% pacientu (Mabro et al., 2006; Bidard et al., 2009). Pacientiem, kas pirmajā līnijā ir saṇēmuši irinotekānu saturošu k,īmijterapiju, otrās līnijas izvēles terapija ir oksaliplatīnu saturošās shēmas. Atbildes reakcija sasniedz 9-15\%, bet laiks līdz progresijai 4,2-4,7 mēneši (Tournigand et al., 2004; Giantonio et al., 2007).

EPIC pētījumā konstatēts, ka cetuksimaba pievienošana irinotekānu saturošai otrās līnijas k,īmijterapijai pagarina laiku līdz progresijai (4,0 vs 2,6 mēneši) un uzlabo audzēja atbildes reakciju (16,4\% vs 4,2\%). Vēlāk EPIC pētījumā iekḷautajiem pacientiem tika noteikts $K R A S$ gēna stāvoklis un konstatēts, ka cetuksimaba pievienošana irinotekānu saturošai terapijai pagarina laiku līdz progresijai pacientiem ar neizmainītu KRAS stāvokli, salīdzinot ar 
pacientiem ar konstatētu KRAS mutāciju (HR 0,77, p = 0,095), (Langer et al., 2008). Arī otra antiepidermālā augšanas faktora monoklonālās antivielas panitumumaba kombinācija ar FOLFIRI pagarina laiku līdz progresijai un uzlabo audzēja atbildes reakciju, bet nepagarina kopējo dzīvildzi (Peeters et al., 2010). Panitumumabs var tikt nozīmēts arī monoterapijā pacientiem, kas iepriekš ir saņēmuši FOLFOX/FOLFIRI terapiju (Mabro et al., 2006). N̦emot vērā pirmās līnijas pētījumu rezultātus, arī turpmākajās līnijās anti-EGFR monoklonālās antivielas var tikt nozīmētas tikai $R A S w t$ pacientiem.

Bevacizumaba pievienošana oksaliplatīnu saturošai otrās līnijas terapijai pagarina laiku līdz progresijai un kopējo dz̄̄vildzi (Giantonio et al., 2007). Ir publicēti vairāku pētījumu rezultāti, kas apstiprina bevacizumaba terapijas efektivitāti arī tiem pacientiem, kuri bevacizumabu ir saṇēmuši pirmajā līnijā (Bennouna et al., 2013; Masi et al., 2015).

Angioǵenēzes inhibitors ziv-aflibercepts uzlabo laiku līdz progresijai (4,7-6,9 mēneši, HR 0,76) un kopējo dzīvildzi (12,1-13,5 mēneši, HR 0,82) kombinētā otrās līnijas terapijā ar FOLFIRI pēc iepriekš saņemtas oksaliplatīnu saturošās terapijas (Van Cutsem et al., 2011). Pozitīvais efekts tika novērots gan tiem pacientiem, kas iepriekš bija saṇēmuši bevacizumabu, gan tiem, kuri to nesaṇēma. Ar̄̄ ramucirumabs ir pierādījis savu efektivitāti otrās līnijas terapijā RAISE pētījumā kombinācijā ar irinotekānu saturošu k,īmijterapiju - PFS pagarinājās par 1,2 mēnešiem, bet OS par 1,6 mēnešiem (Tabernero et al., 2015).

\section{Trešās līnijas terapija}

Konstatējot progresiju pēc pirmās un otrās līnijas saṇemšanas, vēl ir daḷa pacientu, kuru vispārējais stāvoklis pieḷauj trešās līnijas terapiju.

Trifluridīns/tipiracils ir kombinēts medikaments, kuram ir raksturīga laba panesamība un bezprogresijas un kopējās izdzīvotības ieguvums pacientiem ar mKRV. Tas tiek pielietots refraktāra mKRV ārstēšanā - trešajā vai turpmākajās k, kīmijterapijas līnijās pacientiem, kuri ir progresējuši pēc fluoropirimidīnu, anti-EGFR un anti-VEGF terapijas (Mayer et al., 2015).

Trešās līnijas terapijā pacientiem ar neizmainītu $R A S$ stāvokli ir pierādīta anti-EGFR monoklonālo antivielu efektivitāte. Cetuksimabs ir efektīvs gan kopāa ar irinotekānu (MericBernstam et al., 2019), gan monoterapijā (Sartore-Bianche et al., 2016), bet panitumumaba efektivitāte ir pierādīta monoterapijā (Le et al., 2015). Sakarā ar to, ka bevacizumabs nav efektīvs trešās līnijas terapijā (Overman et al., 2017; Okamura et al., 2018), pacientiem, kuriem nav piemērota anti-EGFR terapija, turpmākajās līnijās var tikt izmantots regorafenibs vai trifluridīns/tipiracils.

Selektētiem pacientiem ar refraktāru mKRV otrajā un sekojošajās terapijas līnijās var izmantot jaunos biolog̣iskos medikamentus - HER2 blokatorus, PD-1 inhibitorus, angioǵenēzes 
inhibitorus un $B R A F$ inhibitorus. Jauno medikamentu izmantošana tiek rekomendēta klīnisko pētījumu ietvaros.

\subsection{Metastātiska kolorektālā vēža terapijas efektivitātes rādītāji}

Nozīmējot pacientam paliatīvu medikamentozu terapiju, ir svarīgi monitorēt tās efektivitāti dinamikā. Pastāv vairāki terapijas efektivitātes monitorēšanas veidi. Viena no biežāk pielietojamām metodēm ir audzēja atbildes reakcijas radioloğiskā noteikšana, audzēja antigēnu līmeņa monitorēšana pacienta asin̄̄s. Bez tam tiek arī pētīti jauni molekulārie marķieri, ar kuru palīdzību varētu precīzi agrīni konstatēt vēža recidīvu, progresiju un rezistenci pret k̦īmijterapijas medikamentiem.

\subsubsection{Vēža marķieri}

Karcinoembrionālais antigēns (KEA, angl. carcinoembronal antigen, CEA) ir cirkulējošais biomark,ieris, ko izmanto klīniskajā praksē metastātiska kolorektālā vēža terapijas efektivitātes monitorēšanā. KEA līmenis būtu jānosaka pirms terapijas uzsākšanas un, sekojoši, reizi 1-2 mēnešos k̦īmijterapijas laikā. Vairākos mērījumos konstatēts KEA kāpums var norādīt uz vēža progresiju. Vienu reizi noteikts paaugstināta KEA līmenis pacientam ar metastātisku kolorektālo vēzi terapijas laikā nav terapijas efektivitātes rādītājs. Tranzitora KEA paaugstināšanās var tikt novērota 4-6 nedēlas pēc 5-FU un oksaliplatīnu saturošas kīmijterapijas uzsākšanas un tas neliecina par progresiju. To varētu izskaidrot ar k,īmijterapijas izraisītu aknu toksisku bojājumu (Sorbye et al., 2003; Sorbye et al., 2004). Iemesls paaugstinātam KEA līmenim asinīs var būt arī gastrīts, čūlas slimība, divertikulīts, hroniska obstruktīva plaušu slimība (HOPS), hroniskas aknu slimības, cukura diabēts, kā arī akūtas saslimšanas. Atkārtotās analīzēs noteikts konstants KEA līmeṇa kāpums pārsvarā gadījumu norāda uz terapijas neefektivitāti un vēža progresiju. Šādos gadījumos ir jāveic papildu radioloğiskie izmeklējumi un jāpārskata terapijas izvēle. Kaut arī nav konkrēti definēts, cik lielas KEA līmeṇa izmaiṇas ir vērā n,emamas, ir pieṇemts, ka KEA līmeṇa kāpums, salīdzinot ar iepriekšējo rezultātu, par $30 \%$, kas ir apstiprināts atkārtotā analīzē 1 mēneša laikā, vai arī KEA līmen,a kāpums par 15 \% > 3 mērījumos pēc kārtas (Duffy et al., 2003; Duffy et al., 2007).

Paaugstinātam KEA līmenim pirms radikālas zarnu operācijas ir prognostiska nozīme, bet paaugstināts KEA līmenis pēc operācijas var norādīt uz operācijas neradikalitāti vai okultu metastātisku slimību. Pacientiem ar paaugstinātu KEA pēc operācijas recidīvu konstatē biežāk (Goldstein et al., 2005; Filiz et al., 2009). 
Tomēr ir situācijas, kad KEA līmeṇa izmaiņas nespēj precīzi paredzēt progresiju vai remisiju; pacientam ar zināmu metastātisku kolorektālo vēzi KEA līmenis var būt normāls $(<5 \mathrm{ng} / \mathrm{ml})$.

KEA nav vien̄̄gais imunoloğiskais marḳieris kolorektālā vēža terapijas efektivitātes monitorēšanai. Klīniskajā praksē tiek izmantots arī CA19-9. Ir publicēti vairāki pētījumi, kuros aprakstītas CA19-9 izmaiņas saistībā ar kolorektālā vēža gaitu. Haas et al. retrospektīvajā pētījumā novērota statistiski ticama korelācija starp 5 gadu kopējo dzīvildzi un CA19-9 mazināšanos ḳīmijterapijas laikā $(\mathrm{p}=$ 0,002) (de Haas et al., 2010). Tomēr, tā kā ir salīdzinoši maz pētījumu, kas apstiprinātu CA19-9 nozīmi, un to dati ir pretrunīgi, CA19-9 netiek rekomendēts izmantošanai ikdienas praksē (ASCO, 2006).

Literatūrā ir aprakstīts oksaliplatīna terapijas prediktīvais mark,ieris, DNS labotājgēns ERCC1 (excision repair cross-complementing gene-1). Pacientiem ar zemu ERCC1 ekspresiju vēža audos sliktāk notiek oksaliplatīna terapijas izraisīto DNS bojājumu reparācija, līdz ar to ir lielāka šī medikamenta efektivitāte un labāka kopējā dzīvildze (Shirota et al., 2001). Tomēr praksē šis mark,ieris netiek izmantots, jo tā prediktīvā vērtība nav līdz galam izpētīta, kā arī ar šĩ markiera palīdzību nav iespējams novērtēt terapijas efektivitāti dinamikā.

\subsubsection{Radioloğiskie izmeklējumi}

Audzēja izmēra, tilpuma izmaiņas dinamikā tiek mērītas ikdienas praksē un lielā mērā ietekmē terapijas taktiku. Radioloğiskā remisija korelē ar garāku 5 gadu kopējo dzīvildzi (de Haas et al., 2010).

Diehl et al. 2008.gada pētījumā pacientam ar resnās zarnas vēža aknu metastāzēm, kuram cirkulējošās DNS samazinājās par $99 \%$ pēc k,īmijterapijas saṇemšanas, radioloğiski metastāžu tilpums samazinājās tikai nedaudz. To varētu izskaidrot ar to, ka audzēja metastāze sastāv gan no dz̄īām vēža šūnām, gan audzēja stromas (fibroblasti, asinsvadi, iekaisuma šūnas, nekrotiskie audi, u.c.). Ir arī situācijas, kad radioloğiskie izmeklējumi ir neinformatīvi, bet pacientam ir okulta metastātiska slimība - metastāzes ir sīkas, tās nav iespējams vizualizēt ar pašlaik izmantoto tehnoloǵiju (PET, DT vai KMR). Audzēja metastāzes, kas ir tikai dažus milimetrus lielas, var saturēt miljoniem vēža šūnu (Li et al., 2007).

Radiolog̣iskā audzēja atbildes reakcija ir galvenais klīnikā izmantotais terapijas efektivitātes rādītājs. Tiek izmantota vērtēšanas sistēma pēc noteiktiem objektīviem kritērijiem - RECIST VHO kritērijiem (Eisenhauera et al., 2009). RECIST (angl. Response Evaluation Criteria in Solid Tumours) kritēriji ir izveidoti, lai maksimāli objektīvi un vienādi tiktu izvērtēta radiolog̣iskā atbildes reakcija klīnisko pētījumu ietvaros. Audzējs tiek raksturots, ṇemot vērā mērḳa vienību (metastāžu) skaitu (maksimāli 5 veidojumi, ne vairāk par 2 viena 
orgāna robežās), izmēru (nodulāra metastāze ne mazāka par 10 mm, metastātisks limfmezgls), lokalizāciju atbilstoši pieņemtajām vadlīnijām. Audzēja atbildes reakciju atspogulo vairāki parametri: mērḳa vienību diametru summas izmaiņas dinamikā, nemērķa vienību izmaiņas un no jauna radušās metastāzes. Pacientiem ar metastātisku vēzi audzēja izmēru samazināšanās par $30 \%$ ḳīmijterapijas laikā tiek definēta kā daḷēja remisija, palielināšanās par $20 \%$ progresija, pilnīga izzušana - pilna remisija, bet kā slimības stabilizācija tiek definēta mērḳa vien̄̄bu samazināšanās par $<30 \%$ vai palielināšanās par $<20 \%$. Nemērḳa vienību izmaiṇas un jaunu metastāžu rašanās ietekmē kopējo audzēja radioloǵisko atbildes reakciju (Eisenhauera et al., 2009).

Radiolog̣iskai audzēja dinamikas un terapijas efektivitātes izvērtēšanai tiek izmantota datortomogrāfija, kodolmagnētiskā rezonanse; mazāk nozīmīgas ir pozitronemisijas tomogrāfija, rentgenogrammas.

\subsubsection{Dzīvildze kā terapijas efektivitātes rādītājs}

Terapijas efektivitātes galvenie rādītāji ir audzēja atbildes reakcija (radioloǵiskā un patoloğiskā audzēja atbildes reakcija) un dzīvildze. Dz̄ivildzes pagarinājums norāda uz terapijas efektivitāti.

Klīniskajos pētījumos tiek izmantoti dažādi rādītāji:

1) Laiks līdz progresijai jeb bezprogresijas dzīvildze (angl. progression free survival-PFS) ir laika intervāls no slimības diagnosticēšanas brīža līdz radioloǵiski apstiprinātai progresijai (audzēja izmēru palielināšanās, jaunu metastāžu diagnosticēšana). Pacientu grupai tiek aprēķināta vidējā bezprogresijas izdzīvotība, kas atšķiras no saņemtā medikamentozās terapijas veida, terapijas līnijas un pētāmās pacientu grupas.

2) Kopējā izdzīvotība (angl. Overall survival, OS) - laika intervāls no slimības diagnosticēšanas brīža līdz nāvei. Vidējā kopējā izdzīvotība ir pacientu grupai vidēji aprēḳinātais laiks no diagnozes brīža līdz nāvei; tā tiek mērīta mēnešos. Metastātiska kolorektālā vēža pacientu vidējā izdzīvotība ir atkarīga no pacienta vispārējā stāvokḷa, izvēlētā ārstēšanas veida, slimības izplatības, kā arī individuālajām izmaiņām audzēja genomā. Vidējā izdzīvotība pacientiem ar nerezecējamu kolorektālo vēzi, kas saņem ķ̄imijterapiju, ir 13-22 mēneši. Kopējā izdzīvotība tiek aprēķināta procentos. Onkoloǵijā bieži tiek izmantots 5 gadu kopējās izdzīvotības rādītājs. mKRV 5 gadu izdzīvotība svārstās, atkarībā no pacientu demogrāfiskajiem datiem, slimības plašuma un ārstēšanas veida.

Kopējo izdzīvotību ir vienkārši aprēḳināt, tomēr šim terapijas efektivitātes rādītājam ir vairāki trūkumi. Pirmkārt, nāve iestājas salīdzinoši ilgu laiku pēc pētījuma medikamenta 
pārtraukšanas un tādēl efektivitātes izvērtēšanai vajadzīgi gadi. Otrkārt, lai sasniegtu statistiski ticamu rezultātu, nepieciešams ḷoti liels iekḷauto pacientu skaits. Treškārt, kopējo izdzīvotību ietekmē visi ārstēšanas veidi, kurus pacients ir saņēmis pēc pētāmā medikamenta vai ārstēšanas metodes pabeigšanas.

\subsubsection{Cirkulējošie ǵenētiskie vēža marķieri}

Aizvien vairāk tiek pētīti un klīnikā ieviesti specifiski cirkulējošie vēža marķieri, ar kuru palīdzību varētu prognozēt pacienta dzīvildzi, paredzēt un kontrolēt terapijas efektivitāti. Plaši tiek pētīti dažādi epiğenētiskie mark,ieri (piem., p16INK4A, p14ARF,MGMT,HPP1,HLTF,ID4, CIMP), (Schetter et al., 2008; Ogino et al., 2009), ğenētiskie mark,ieri (RNS), cirkulējošās vēža šūnas, cirkulējošā vēža DNS un to ietekme uz mKRV slimības gaitu.

\section{mikroRNS}

Pētījumi rāda, ka mikroRNS līmenis plazmā var norādīt uz audzēja attīstību ( $N g$ et al., 2009); arī to ekspresija audzēja audos var norādīt uz slimības iznākumu. Schou et al. 2011 pêtījumā, kurā tika iekḷauti 144 pacienti ar metastātisku kolorektālo vēzi, miR-31, let-7g un miR-424 mikroRNS ekspresijas izmaiṇas trešās līnijas k,īmijterapijas laikā korelēja ar kopējās dzīvildzes datiem (Schou et al., 2011).

Atsevišķi mikroRNS tipi var paredzēt taisnās zarnas vēža kombinētās staru un k̦īmijterapijas efektivitāti. Tādi mikroRNS, kā has-miR-765, has-miR-1183, hsv-miR-H1, hsamiR-483-5p, has-miR-622, hsa-miR-125a-3p, has-miR1224-5p, has-miR-188-5p, has-miR1471, has-miR-671-5p, has-miR1909STAR, has-miR-630 ekspresija korelē ar pilnas patolog̣iskās remisijas biežumu operācijas materiālā pēc saṇemtās terapijas (Scarpati et al., 2011).

\section{Cirkulējošās vē̌̆a šūnas}

Cirkulējošā vēža DNS nepārprotami norāda uz vēža klātbūtni organismā, bet cirkulējošo vēža šūnu (CVŠ) izmantošana terapijas efektivitātes monitorēšanā ir pretrunīga. Teorētiski CVŠ samazināšanās terapijas laikā varētu norādīt uz ārstēšanas efektivitāti un tam būtu jāsakrīt ar radioloǵisko atradi. Gazzaniga et al. 2011. gadā aprakstīja CVŠ saistību ar cetuksimaba un bevacizumaba terapijas efektivitāti. CVŠ mazināšanās cetuksimaba terapijas laikā pacientiem ar mKRV korelēja ar pozitīvu radioloğisko atbildi, bet pacientiem, kuri san̄ēma bevacizumabu, CVŠ mazināšanās nekorelēja ar pozitīvu audzēja atbildes reakciju.

Cirkulējošo vēža šūnu klātbūtne tiek pētīta arī pacientiem ar rezektablām kolorektālā vēža metastāzēm pirms un pēc operācijas. Pētījumu dati ir pretrun̄̄gi - ir konstatēta saistība 
starp cirkulējošo vēža šūnu klātbūtni asin̄̄s un nelabvēlīgu slimības prognozi (Cohen et al., 2008; Teijeira et al., 2011).

\section{Molekulārie marķieri}

Audzēja monitorēšana k,īmijterapijas laikā un pēc tās pabeigšanas lielākoties notiek, izmantojot attēldiagnostikas metodes - DT, KMR, kā arī dažu lokalizāciju audzēju gadījumos monitorē cirkulējošos audzējam specifiskos markiierus (piem., PSA prostatas vēža un CA125 olnīcu vēža monitorēšanā). Hematoloğisku audzēju gadījumā ārstēšanas efektivitātes un slimības aktivitātes monitorēšanai tiek izmantoti cirkulējošie ğenētiskie mark,ieri - slimībai specifiskas hromosomālās aberācijas, kuru daudzums asin̄̄s korelē ar audzēja progresiju. Klasisks piemērs ir $B C R-A B L$ translokācija hroniskas mieloleikozes gadījumā. Pacientiem ar zemu $B C R-A B L$ transkripta līmeni asin̄̄s ir paredzama ilgstoša remisija, bet gadījumos, kad ǵenētiskais markieris asin̄̄s dinamikā paaugstinās, ir sagaidāma slimības progresija (akselerācija) vai rezistences veidošanās uz saņemto terapiju (Press et al., 2006).

Solīdo audzēju gadījumā ikdienas praksē netiek monitorēti cirkulējošie ǵenētiskie marḳieri, jo nav zināmas universālas translokācijas vai citas hromosomālās mutācijas, kas būtu raksturīgas kādam audzēja veidam. Tomēr, līdzīgi kā hematolog̣isku neoplāziju gadījumā, pacienta asinsritē nonāk audzēja DNS un teorētiski tās līmeni asinīs kvantitatīvi var monitorēt. Iepriekš ir aprakstīti pētījumi, kuros pacientiem ar solīdiem audzējiem, tostarp kolorektālo vai plaušu vēzi, perifērajās asin̄̄s kvantitatīvi nosaka audzējam specifiskās punktveida mutācijas saturošu DNS (Diehl et al., 2008; Fleischhacker et al., 2007).

Kā marķieris tiek izmantotas punktveida mutācijas vēža DNS (Diehl et al., 2008; Yung et al., 2009). Lai ar̄̄ patreiz jaunākās paaudzes sekvenēšana ir pieejama tikai atseviškāās zinātniskajās laboratorijās, nākotnē ir paredzama šo tehnoloğiju ieviešana klīniskajā praksē, kas ievērojami atvieglotu terapijas efekivitātes monitorēšanu, l,autu novērot slimības attīstību ilgtermin̄ā reālajā laikā.

Dažu audzēju gadījumā ir zināmas audzējam raksturīgās hromosomālās aberācijas ETS prostatas vēža un Jūinga sarkomas gadījumā, EML4-ALK translokācija nesīkšūnu plaušu vēža gadījumā, bet šo DNS izmain,u izmantošana klīniskajā praksē katram pacientam ir ierobežota, jo aberācija sastopama nelielai pacientu daḷai (Tomlins et al., 2005; Tomlins et al., 2007; Vermeulen et al., 2006; Soda et al., 2007).

Biežāk solīdo audzēju DNS ir mutācijas, kas ir specifiskas katram konkrētajam pacientam. Pētījumi rāda, ka hromosomālās aberācijas, kas atrastas primārā audzēja DNS, var tikt izmantotas kā ǵenētiskais mark,ieris, un tikt noteiktas slimības gaitas un terapijas efektivitātes monitorēšanai (McBride et al., 2010; Leary et al., 2010). Tādā veidā būtu 
iespējams monitorēt vēža DNS slodzi pacientiem ar solīdiem audzējiem, līdzīgi kā to dara hematoloğisku neoplāziju gadījumā. Nākotnē, samazinoties izmaksām, pilna vēža DNS sekvenēšana katram pacientam būs standarta izmeklēšanas metode, kas dos iespēju piemeklēt katram pacientam individuāli uz DNS mutāciju vērstu mērk,a terapiju, kontrolēt tās efektivitāti un monitorēt slimības gaitu. Agrīna slimības progresijas noteikšana, izmantojot personalizētu ǵenētisko biomarḳieri, l,autu izvairīties no neefektīvas terapijas turpināšanas, kāa arī dotu iespēju uzsākt ārstēšanu, pirms pacientam rastos ar slimību saistīti simptomi un komplikācijas. Iepriekš pētījumos ir iegūti dažādi (arī pretrunīgi) dati atšķirīgu vēža lokalizāciju terapijas taktikas izvēlē. Piemēram, olnīcu vēža pacientēm kopējo dz̄ivildzi neietekmē ḳīmijterapijas uzsākšana, kas balstīta uz agrīni noteiktu bioḳīmisko recidīvu - CA125 pieaugumu dinamikā (Rustin et al., 2010).

Audzēja monitorēšana reālajā laikā, nosakot vēža cirkulējošās DNS slodzi, ir svarīga, ārstējot pacientus ar eksperimentāliem medikamentiem klīnisko pētījumu ietvaros, ar pretvēža mērķa terapiju, kā arī ārstējot ar citotoksiskiem medikamentiem, kuriem ir biežas un smagas blakusparādības. Agrīni nosakot molekulāro recidīvu, ir iespējams izvairīties no neefektīvas, dārgas un toksiskas terapijas turpināšanas. Tas ir ceḷš uz personalizētu medicīnu, nosakot terapijas ilgumu un intensitāti katram pacientam individuāli.

Cirkulējošās vēža DNS noteikšana asin̄̄s ir izaicinājums, jo tā sastāda tikai 0,01\% no visas asin̄̄s atrodamās DNS (Diehl et al., 2005). Diehl et al. 2008.gadā publicētajā pētījumā pacientiem, kuriem pēc kolorektālā vēža metastāžu rezekcijas konstatēja vēža DNS asin̄̄s, salīdzinot ar pacientiem, kuriem to nekonstatēja, tika novērota statistiski ticama beznotikumu dzīvildzes atšḳirība. Līdzīga korelācija novērota pacientiem ar paaugstinātu vai normālu CEA līmeni.

Pētījumi parāda, ka cirkulējošā vēža DNS ir daudzsološs biomarkieris, ar kura palīdzību varētu noteikt izdarītās paliatīiās operācijas apjomu, paredzēt slimības progresijas ātrumu pēc operācijas, monitorēt kīmijterapijas efektivitāti. cDNS ir jut̄̄gāks un precīzāks terapijas efektivitātes seruma marḳieris nekā CEA un radioloğiskais novērtējums (Pantel et al., 2008; Maheswaran et al., 2008). 


\section{Materiāls un metodes}

Pētnieciskais darbs sastāv no 3 daḷām (2.1. att.):

1) Paula Stradiṇa Klīniskās universitātes slimnīcas Onkologijas klīnikā ārstēto nerezecējama mKRV pacientu analīze;

2) Klīnisko prognostisko un prediktīvo faktoru analīze pacientiem, kas saṇem FTD/TPI;

3) Chromothripsis kā metastātiska kolorektālā vēža prediktīvais faktors.

Pētījums veikts P.Stradiṇa Klīniskās universitātes slimnīcas Onkoloğijas klīnikā un RSU Onkoloğijas institūtā.

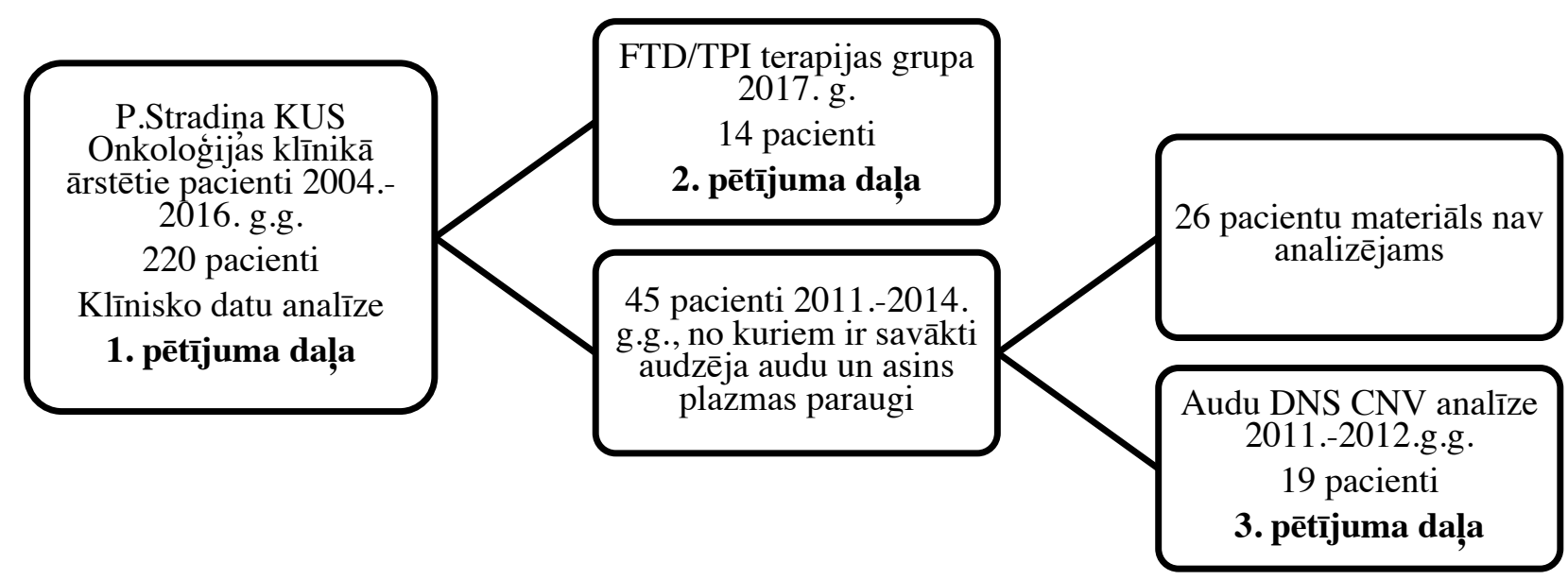

2.1. att. Promocijas darba uzbūve

\subsection{Nerezecējama mKRV analīze P.Stradiņa KUS Onkoloğijas klīnikāa}

\section{Pētāmā grupa}

Retrospektīvā pētījumā apkopoti 220 pacienti ar nerezecējamu metastātisku kolorektālo vēzi (C18-C20), kas ārstēti P.Stradiṇa KUS Onkolog̣ijas klīnikā (18. nodaḷā vai 12. dienas stacionārā) laika posmā no 2004. gada jūnija līdz 2016. gada decembrim. Dati iegūti no medicīniskās dokumentācijas - ambulatorajām kartēm, dienas stacionāra un stacionāra kartēm, programmas “Ārstu birojs”, radiolog̣isko izmeklējumu atbilžu programmas “AI-RIS PSKUS”. Pacientu miršanas datumi iegūti no Slimību Profilakses un Kontroles centra (SPKC).

\section{Iekḷaušanas kritēriji:}

1. Pacientam ir diagnosticēts metastātisks resnās vai taisnās zarnas vēzis ar nerezecējamām metastāzēm. Pacienti, kuriem pēc ķīmijterapijas tika veikta metastāžu rezekcija, tika izslēgti no pētījuma.

2. Pacients ir saṇēmis vismaz divus paliatīvās ķīmijterapijas kursus. 
3. Pacienta medicīniskajā dokumentācijā ir atrodami dati par saņemto ķ̄imijterapiju, novērošanu, ir veikti dinamiski kontroles izmeklējumi un fiksēts progresijas datums. Pacienti, kuri neieradās uz ķīmijterapiju un dinamiskās novērošanas vizītēm, tika izslēgti no pētījuma.

\section{Statistiskā analīze}

Tika apkopoti dati par vecumu, dzimumu, diagnozes datumu, stadiju, pirmās un otrās līnijas k̦īmijterapijas veidu, radioloğiskos izmeklējumos apstiprinātas progresijas datumu, metastāžu lokalizāciju un nāves datumu.

Iegūtie rezultāti ievadīti Excell datu bāzē, veikta statistiskā analīze, izmantojot MedCalc statistiskās analīzes programmu, v.16.4.8 (MedCalc Software, Ostend, Beḷgija). Kopējā izdzīvotība (OS) un bezprogresijas izdzīvotība (PFS) aprēkināta, izmantojot Kaplana-Meijera metodi, log-rank testu un daudzfaktoru Cox regresijas metodi.

\subsection{Klīnisko prognostisko un prediktīvo faktoru analīze pacientiem, kas saṇem FTD/TPI}

\section{Pètāmā grupa}

Analizēti 14 pacienti ar mKRV, kas saṇēma FTD/TPI k,īmijterapiju Latvijā no 2016. gada aprīla līdz 2017. gada janvārim (P.Stradiṇa KUS/Onkoloğijas klīnika un RAKUS/Latvijas Onkoloğijas centrs) Lonsurf pirmsreğistrācijas pacientu atbalsta programmas ietvaros. Visi pacienti ir parakstījuši pētāmā informētās piekrišanas formu.

\section{Ieklıušanas kritēriji:}

1. Metastātisks kolorektāls vēzis.

2. Apmierinoša orgānu un kaulu smadzeņu darbība: absolūtais neitrofīlo leikocītu skaits $>1,5 \times 10^{9} / \mathrm{L}$, trombocītu skaits $>75 \times 10^{9} / \mathrm{L}$, hemoglobīna līmenis $>9,0 \mathrm{~g} / \mathrm{dl}$.

3. Vismaz divas iepriekš saņemtas paliatīvās ķīmijterapijas līnijas, kā rezultātā iegūta rezistence vai nepanesama toksicitāte pret fluoropirimidīniem, oksaliplatīnu un irinotekānu.

Pacienti novēroti līdz 2017. gada jūnijam, 1-13 mēnešus (vidēji 7,1 mēn.).

Ārstēšanas plāns: FTD/TPI tika nozīmēts $35 \mathrm{mg} / \mathrm{m}^{2}$ devā, divas reizes dienā, 5 dienas nedēḷā (kam seko divu dienu pārtraukums), divas nedēlas, ar sekojošu 14 dienu pārtraukumu. Šādi ārstēšanas kursi tika atkārtoti ik pēc 4 nedēẹām. Ārstēšana tika pārtraukta pēc radioloğiski vai klīniski pierādītas vēža progresijas. 


\section{Statistiskā analīze}

Laiks līdz progresijai (PFS) tika aprēkināts no FTD/TPI uzsākšanas līdz klīniskai vai radioloğiski dokumentētai progresijai, bet kopējā dzīvildze (OS) - no FTD/TPI uzsākšanas līdz nāves brīdim.

Iegūtie rezultāti ievadīti datu bāzē, veikta to statistiskā analīze, izmantojot MedCalc statistiskās analīzes programmu, v.16.4.8 (MedCalc Software, Ostend, Belĝ̣ja). Kopējās izdzīvotības (OS) un bezprogresijas izdzīvotība (PFS) aprēḳinātas, izmantojot Kaplana-Meijera metodi un log-rank testu.

\subsection{Chromothripsis kā metastātiska kolorektālā vēža prediktīvais faktors}

\section{Pètāmā grupa}

Prospektīvs pētījums, kurā iekḷauti 19 pacienti ar diagnosticētu metastātisku kolorektālo vēzi, kuriem ir iegūti audi no operācijas materiāla, un kuri saṇēma paliatīvu ķīmijterapiju Paula Stradiṇa Klīniskās universitātes slimnīcas Onkolog̣ijas klīnikā no 2011. gada līdz 2012. gada

\section{Iekļaušanas kritêriji:}

1. Histologiski pierādīta metastātiska resnās vai taisnās zarnas adenokarcinoma.

2. Radioloǵiski mērāmi lielumi, atbilstoši RECIST v 1.1 kritērijiem.

3. Pacients iepriekš nav saņēmis k̦īmijterapiju metastātiska vēža ārstēšanai.

4. Vispārējais stāvoklis pēc ECOG skalas - 0, 1 vai 2.

5. Vecums $>18$ gadiem.

6. Pacientiem ir indicēta FOLFOX tipa pirmās līnijas ķīmijterapija.

7. Apmierinoša orgānu un kaulu smadzeņu darbība: absolūtais neitrofîlo leikocītu skaits $>1,5 \times 10^{9} / \mathrm{L}$, trombocītu skaits $>100 \times 10^{9} / \mathrm{L}$, bilirubīns $<2$ reizes virs normas, ASAT un ALAT $<5$ reizes virs normas, kreatinīns $<1,5$ reizes virs normas.

8. Parakstīta pacienta informētās piekrišanas forma.

\section{Izslēgšanas kritêriji:}

1. Pierādītas smadzeņu metastāzes.

2. Blakusslimības: nekontrolēts cukura diabēts, aktīva infekcijas slimība, nekontrolēta kardiovaskulāra saslimšana, nedzīstošas brūces. 
Terapijas plāns:

1. Pirmās līnijas ķīmijterapijas veids - oksaliplatīnu saturoša FOLFOX tipa ķīmijterapija (mFOLFOX-6 vai FOLFOX4) - ik pēc 2 nedẹlāam ar vai bez monoklonālo antivielu pievienošanas (2.1. tab.).

Ķīmijterapijas veidi un atšifrējums

2.1. tabula

\begin{tabular}{|l|l|l|l|l|}
\hline Shēma & Medikaments & Deva & Ievades veids & Diena \\
\hline mFOLFOX6 & Oksaliplatīns & $85 \mathrm{mg} / \mathrm{m}^{2}$ & i/v infūzija $2 \mathrm{~h}$ & $\mathrm{~d} 1$ \\
\hline & Leukovorīns (LV) & $400 \mathrm{mg} / \mathrm{m}^{2}$ & i/v infūzija $2 \mathrm{~h}$ & $\mathrm{~d} 1$ \\
\hline & $5-\mathrm{FU}$ & $400 \mathrm{mg} / \mathrm{m}^{2}$ & i/v bolus pēc LV, tam seko: & $\mathrm{d} 1$ \\
\hline & $5-\mathrm{FU}$ & $2400 \mathrm{mg} / \mathrm{m}^{2}$ & $\begin{array}{l}\text { i/v nepārtraukta infūzija } \\
46-48 \mathrm{~h}\end{array}$ & $\mathrm{~d} 1$ \\
\hline FOLFOX4 & Oksaliplatīns & $85 \mathrm{mg} / \mathrm{m}^{2}$ & i/v infūzija $2 \mathrm{~h}$ & $\mathrm{~d} 1$ \\
\hline & Leukovorīns (LV) & $200 \mathrm{mg} / \mathrm{m}^{2}$ & i/v infūzija $2 \mathrm{~h}$ & $\begin{array}{l}\mathrm{d} 1 \text { un } \\
\text { d2 }\end{array}$ \\
\hline & 5-FU & $200 \mathrm{mg} / \mathrm{m}^{2}$ & i/v bolus pēc LV, tam seko: & $\begin{array}{l}\text { d1 un } \\
\text { d2 }\end{array}$ \\
\hline & 5-FU & $600 \mathrm{mg} / \mathrm{m}^{2}$ & $\begin{array}{l}\text { i/v nepārtraukta infūzija } \\
\text { 22-24h }\end{array}$ & $\begin{array}{l}\text { d1 un } \\
\text { d2 }\end{array}$ \\
\hline
\end{tabular}

$\mathrm{i} / \mathrm{v}$ - intravenozi; $\mathrm{d}$ - diena; 5-FU - 5-fluorouracils

2. Ķīmijterapijas ilgums - līdz slimības progresijai vai nekontrolējamai toksicitātei, vismaz 4 reizes, optimāli 8-12 reizes.

3. KEA noteikšana pirms katra terapijas kursa, datortomogrāfijas (DT) kontrole reizi 2 mēnešos.

4. Novērošana pēc ķīmijterapijas pabeigšanas - KEA noteikšana reizi mēnesī, DT kontrole reizi 2 mēnešos - līdz progresijai.

Datu iegūšanas metodes:

1. Klīnisko parametru izvērtēšana - pacienta vecums, dzimums, stadija pēc TNM klasifikācijas, ķīmijterapijas shēma, kursu skaits, laiks līdz slimības progresijai, kopējais dzīves ilgums.

2. Primārā audzēja paraugu iegūšana no parafīna blokiem turpmākai genoma analīzei.

3. DNS izdalīšana no parafīna blokiem ar audzēja audiem, izmantojot QIAmp DNA Mini Kit (Qiagen, Vācija) pēc ražotāja norādījumiem. Kvalitāte noteikta ar Illumina FFPE QC kit (Illumina, ASV) ar reverso transkripcijas PCR metodi (RotorGene6000, Corbett, Qiagen, Vācija). DNS restaurēts ar Illumina DNA restoration kit (Illumina, ASV). 


\section{Statistiskā analīze}

Veikta audzēja genoma analīze un intrahromosomālo aberāciju noteikšana, izmantojot HumanOmniExpress- 12v1.0 FFPE BeadChip kit (Illumina, ASV), rezultāti skenēti HiScan (Illumina, ASV).

Turpmāk veikta genoma analīze, izmantojot GenomeStudio software (Illumina) un $\mathrm{R}$ v3.1.2 (https://www.r-project.org/). Kopiju skaita variāciju un hromosomu lūzumpunktu analīze veikta ar DNA copy package (http://bioconductor.org/packages/release/bioc/html/DNAcopy.html).

Iegūtie rezultāti ievadīti datu bāzē, veikta statistiskā analīze, izmantojot MedCalc statistiskās analīzes programmu, v.16.4.8 (MedCalc Software, Ostend, Beḷgíja). Kopējā izdzīvotība (OS) un bezprogresijas izdzīvotība (PFS) aprēkināta, izmantojot Kaplana-Meijera metodi un log-rank testu. 


\section{Rezultāti}

\subsection{Nerezecējama mKRV analīze P.Stradiṇa KUS Onkoloǵijas klīnikā}

220 pacienti, kas ar nerezecējamu mKRV diagnozi saņēma paliatīvu k,īmijterapiju P.Stradiṇa KUS 2004.-2016. gadā., tika iekḷauti retrospektīvā pētījumā.

Pētījumā iekḷauti 120 vīrieši $(54,5 \%)$ un 100 sievietes (45,5\%), pacientu vidējais vecums bija $63 \pm$ SD10,2 (22-78, $95 \%$ KI 62-65) gadi. 28 pacienti (12,7 \%) bija jaunāki par 50 gadiem (3.1. att.).

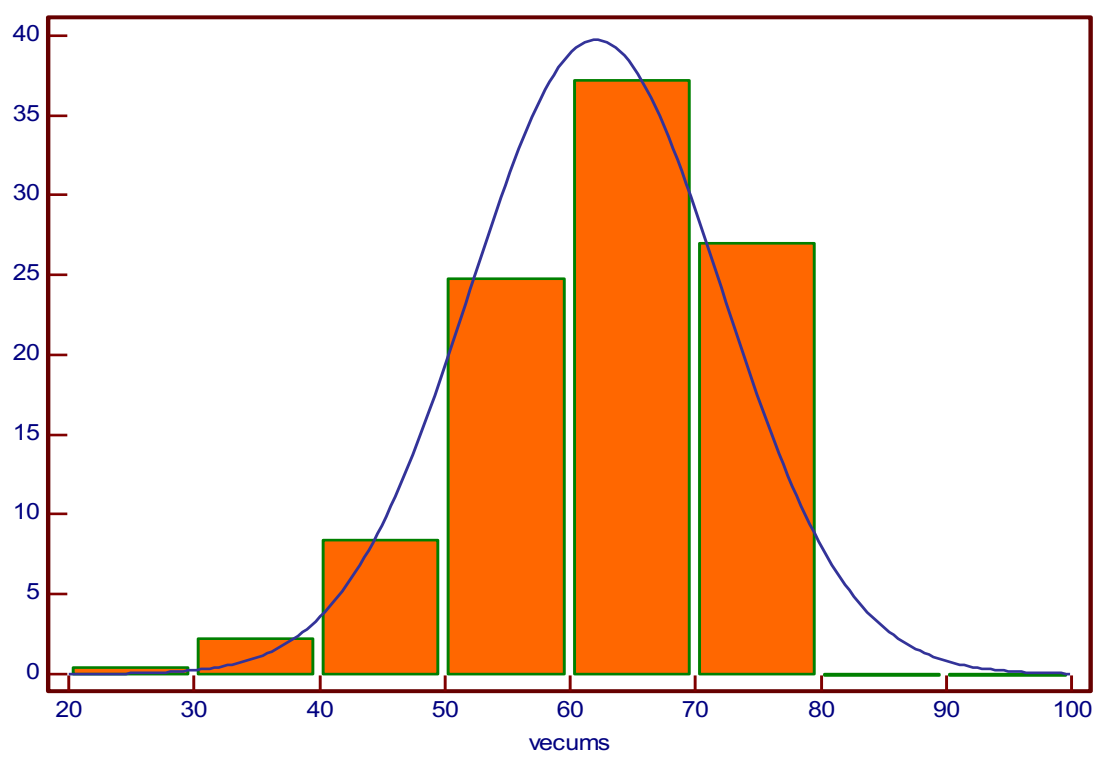

3.1. att. Pacientu sadahijums pa vecuma grupām

106 pacientiem (48,2 \%) mKRV diagnosticēts laika posmā no 2004. līdz 2011. gadam, bet 114 pacientiem $(51,8 \%)$ - no 2012. līdz 2016. gadam.

143 pacientiem (65 \%) bija sinhrons jeb primāri metastātisks vēzis (IV stadija), bet 77 pacientiem (35\%) bija metahrons mKRV, kad metastātiska slimība attīstījās $>6$ mēnešus pēc radikālas audzēja ārstēšanas (I-III stadija). Metahronā mKRV grupā 46 pacientiem (59,7 \%) sākotnēji bija III stadija (T2-4N+), 26 pacientiem (33,8 \%) - II stadija (T3-4N0), 3 pacientiem $(3,9 \%)$ - I stadija (T2N0), bet 2 pacientiem $(2,6 \%)$ precīza sākotnējā stadija nav zināma.

Metahrona mKRV grupā metastātiskā slimības izplatība konstatēta vidēji 18 mēn. (6-84 mēn.) pēc primārā audzēja diagnosticēšanas. 70 pacientiem bija zināms primārā audzēja diagnosticēšanas datums un stadija, no tiem N+ pacientiem $(n=42)$ vidējais laiks līdz metastāžu diagnosticēšanai bija 16,5 mēn., bet N0 pacientiem $(n=28)$ - 20 mēneši $(H R \quad 0,4917$, $95 \%$ KI 0,2929-0,8257, $\mathrm{p}=0,0073)$. 
187 pacientiem (85 \%) bija piejama precīza informācija par metastāžu lokalizāciju. 92 pacientiem (41,8 \%) bija aknu metastāzes, 16 pacientiem $(7,3 \%)$ plaušu metastāzes, 31 pacientam $(14,1 \%)$ vēdera dobuma limfmezglu vai vēderplēves metastāzes, 48 pacientiem $(21,8 \%)$ metastāzes vairākos orgānos, bet 33 pacientiem $(15 \%)$ nebija precīzu datu par metastāžu izplatību (3.2. att.).

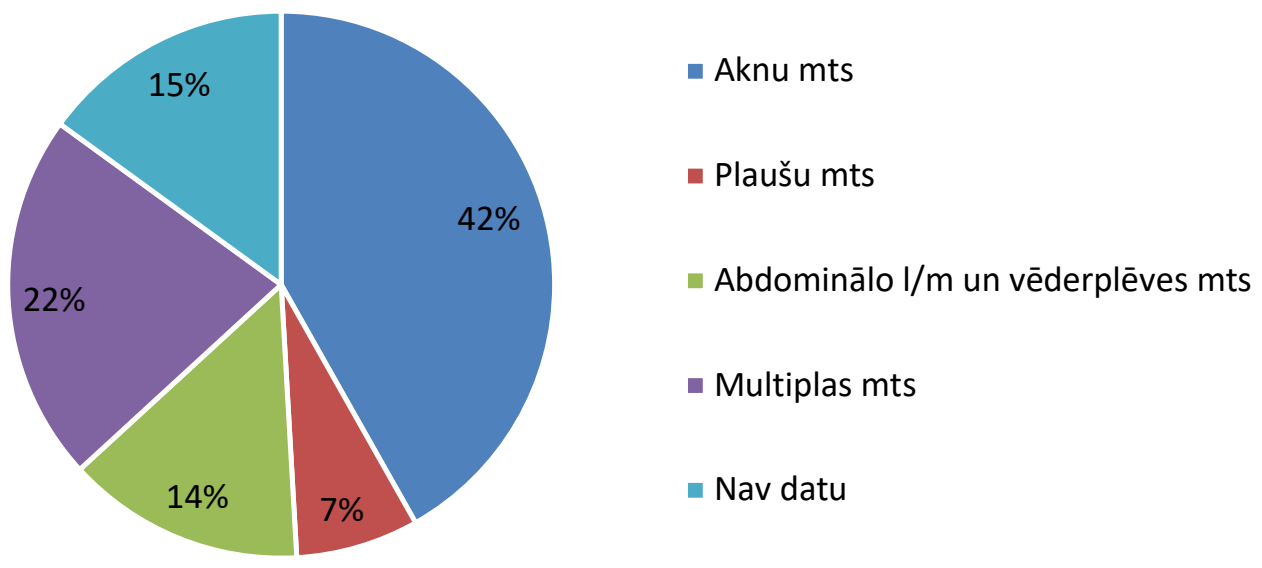

3.2. att. Metastāžu lokalizācija pētījumā iekḷautajiem pacientiem mts - metastāzes, $1 / \mathrm{m}$ - limfmezgli

\section{Pirmās līnijas k̦īmijterapija}

Visi pētījumā iekḷautie pacienti saṇēma vismaz divus pirmās līnijas ķīmijterapijas kursus. Biežākais ḳ̄mijterapijas veids bija FOLFOX tipa k̦īmijterapija (mFOLFOX6 vai FOLFOX4) - to saṇēma 127 pacienti (57,7 \%). FOLFOX ar monoklonālo antivielu terapiju saņēma 24 pacienti (10,9 \%), p/o Ftorafur un oksaliplatīna terapiju san̄ēma 29 pacienti $(13,1$ \%), fluoropirimidīnu monoterapiju (kapecitabīns, 5FU, Ftorafur) san̄ēma 25 pacienti $(11,4 \%$ ), irinotekānu saturošu terapiju - 15 pacienti $(6,8 \%)$ (3.3. att.). 


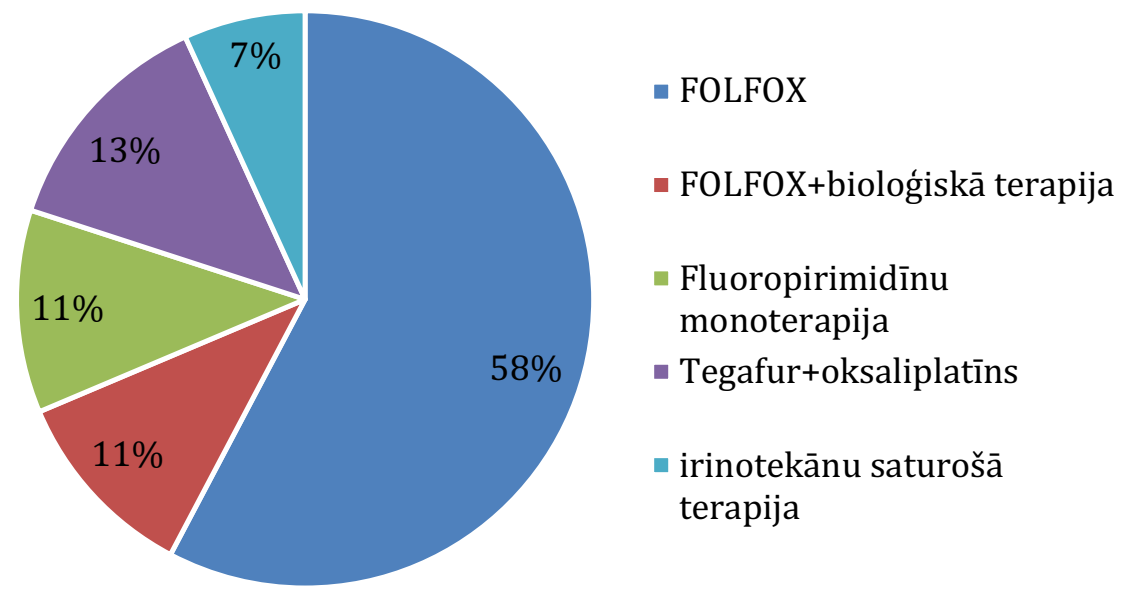

3.3. att. Pirmās līnijas k̦īmijterapija

Sinhrona mKRV grupā FOLFOX tipa terapiju saṇēma 58,7 \% pacientu, FOLFOX ar monoklonālajām antivielām - 10,5 \%, Tegafur un oksaliplatīnu - 11,6 \%, fluoropirimidīnu monoterapiju - 14,3\%, bet irinotekānu saturošu terapiju - $4 \%$.

Metahrona mKRV grupā FOLFOX tipa terapiju saṇēma 55,8 \% pacientu, FOLFOX ar monoklonālajām antivielām - 11,7 \%, Tegafur un oksaliplatīnu - 15,6 \%, fluoropirimidīnu monoterapiju - 5,2 \%, bet irinotekānu saturošu terapiju - 11,7 \% (3.4. att.).

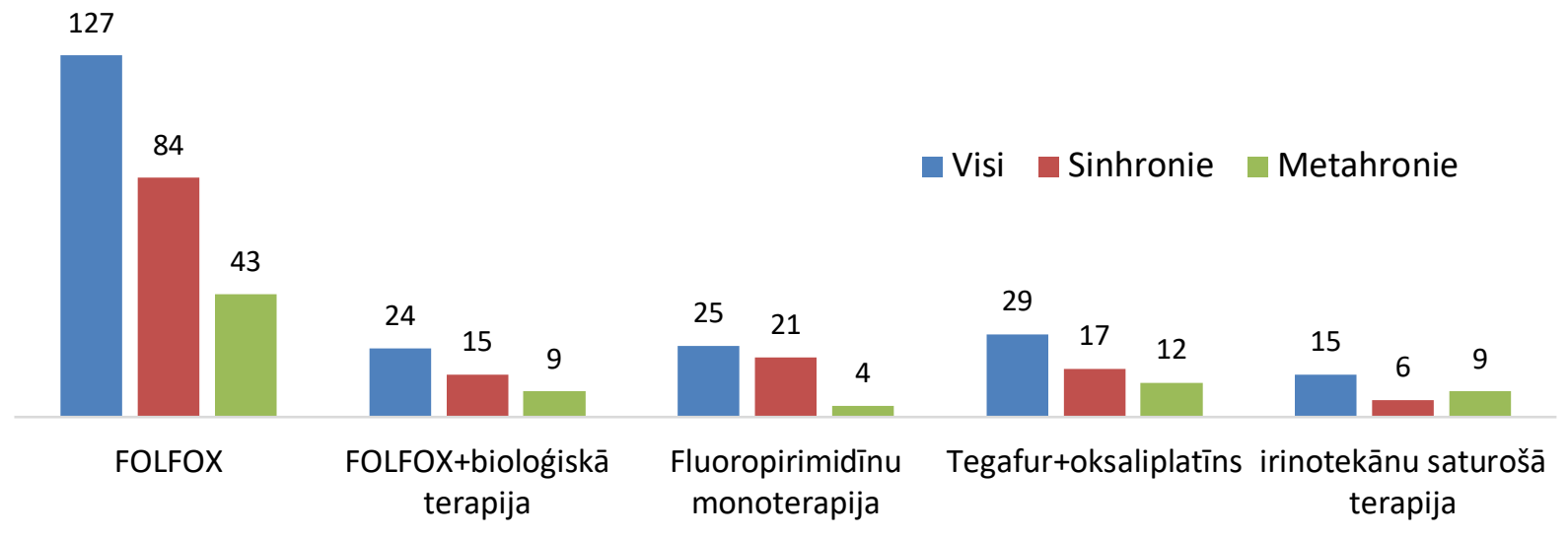

3.4. att. Pirmās līnijas ķīmijterapijas veidi

\section{Otrās līnijas k̦īmijterapija}

To san̄ēma 125 pacienti $(56,8 \%$ ), bet 95 pacienti $(43,1 \%)$ kīmijterapiju neturpināja. Biežāk lietotā k̦īmijterapija bija FOLFIRI, ko saņēma 95 pacienti (76 \% no tiem, kas saṇēma otrās līnijas k,īmijterapiju), FOLFIRI ar monoklonālajām antivielām saṇēma 11 pacienti 
$(8,8 \%)$, fluoropirimidīnu monoterapiju - 16 pacienti $(12,8 \%)$, bet oksaliplatīnu saturošu terapiju -3 pacienti $(2,4 \%)$, (3.5.att.).

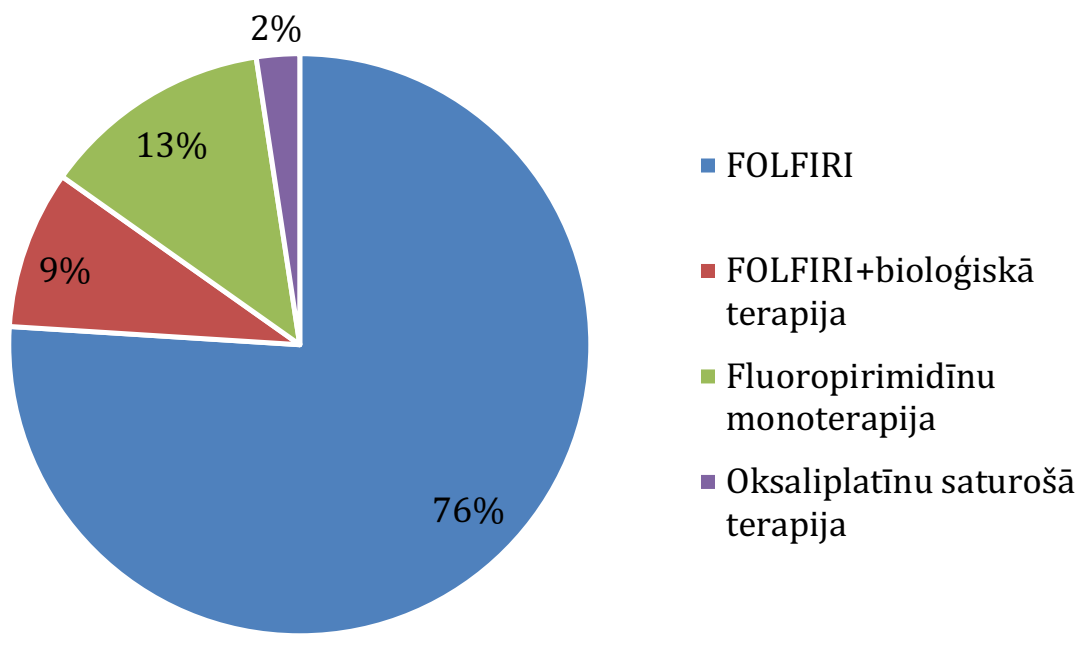

\section{5. att. Otrās līnijas ķīmijterapija}

Sinhrona mKRV grupā 86 pacienti saṇēma 2. līnijas terapiju (60,1\%). Biežākā terapijas izvēle bija FOLFIRI, tā nozīmēta 67 pacientiem (77,9 \%), FOLFIRI ar monoklonālajām antivielām -7 pacientiem $(8,1 \%)$, fluoropirimidīnu monoterapija - 9 pacientiem $(10,5 \%)$, bet oksaliplatīnu saturoša terapija -3 pacientiem $(3,5 \%)$.

Metahrona mKRV grupā 39 pacienti saņēma 2. līnijas terapiju (50,6 \%). FOLFIRI saņēma 28 pacienti (71,8 \%), FOLFIRI ar monoklonālajām antivielām - 4 pacienti (10,3 \%), fluoropirimidīnu monoterapiju - 7 pacienti (17,9 \%). Oksaliplatīnu saturošu terapiju 2. līnijā nesaņēma neviens šīs apakšgrupas pacients (3.6. att.).

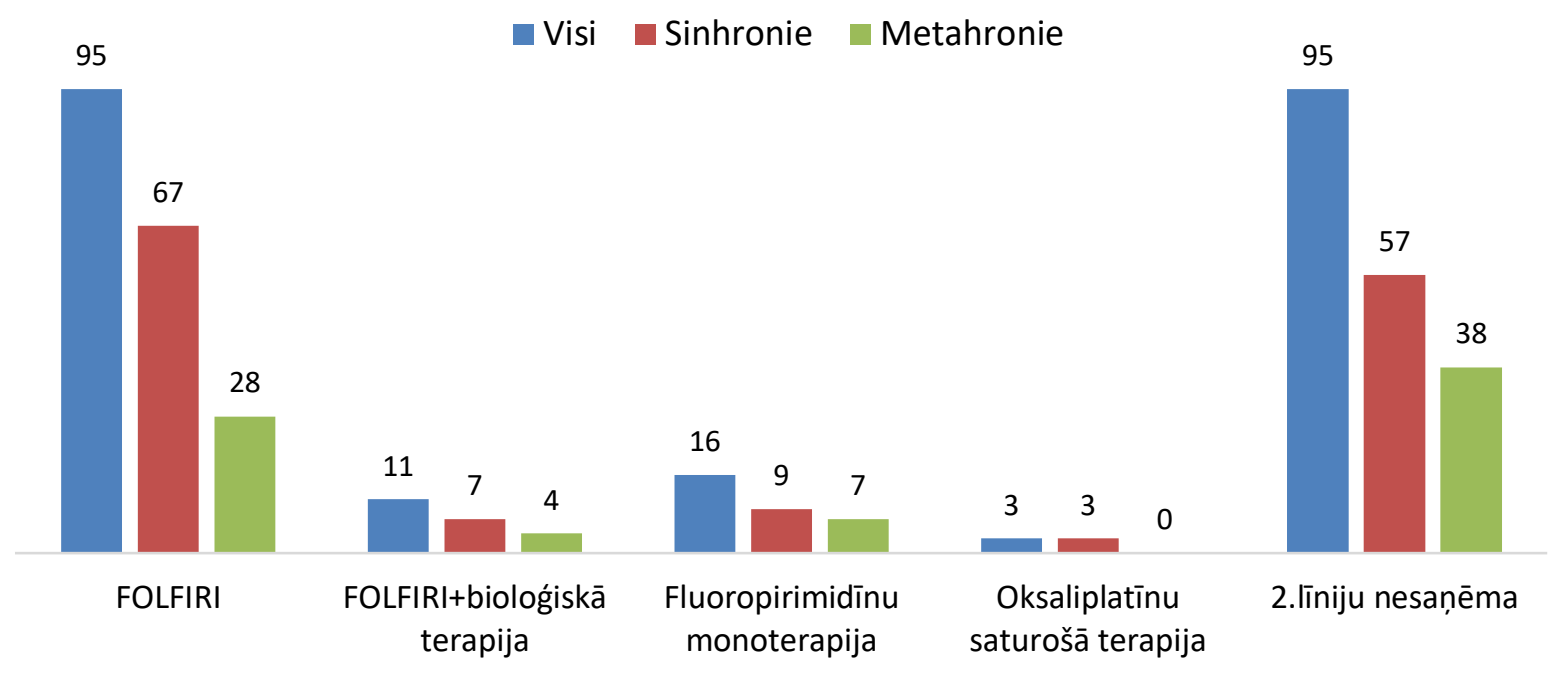

3.6. att. Otrās līnijas ḳīmijterapijas veidi 


\section{Izdż̄̄votības analīze}

Kopējā izdzīvotība un bezprogresijas izdzīvotība visiem pêtījumā iekḷautajiem pacientiem $(n=220)$ atspogulota 3.1. tabulā. Vidējā kopējā izdzīvotība (mOS) bija 17 mēneši, bet vidējā bezprogresijas izdzīvotība (mPFS) - 8 mēneši. 5 gadu kopējā izdzīvotība bija 3,1 \% .

Izdzīvotības rādītāji pētījumā iekḷautajiem pacientiem $(\mathbf{n}=220)$

\begin{tabular}{|l|c|l|c|}
\hline Izdzīvotība & Kopējā grupa & Izdzīvotība & $\begin{array}{l}\text { Kopējā } \\
\text { grupa }\end{array}$ \\
\hline mOS (mēn) & 17 & mPFS (mēn) & 8 \\
\hline 1yOS & $66,6 \%$ & 6mPFS & $60,4 \%$ \\
\hline $\mathbf{2 y O S}$ & $25,2 \%$ & $\mathbf{1 2 m P F S}$ & $20 \%$ \\
\hline 3yOS & $8,6 \%$ & $\mathbf{1 8 m P F S}$ & $5,70 \%$ \\
\hline 4yOS & $4,3 \%$ & $\mathbf{2 4 m P F S}$ & $1,70 \%$ \\
\hline 5yOS & $3,1 \%$ & & \\
\hline
\end{tabular}

mOS - median overall survival (vidējā kopējā izdzīivotība); 1yOS - 1 year overall survival (1 gada kopējā izdzīvotība); mPFS - median progression free survival (vidējā bezprogresijas izdzīvotība); $6 \mathrm{mPFS}$ - 6 month progression free survival (6 mēnešu bezprogresijas izdzīvotība)

Analizējot atseviški sinhrona mKRV un metahrona mKRV izdzīvotību, netika konstatēta ne mPFS (8 vs 8 mēn.), ne mOS atškirība (17 vs 17 mēn.). 5 gadu OS bija labāka metahrona mKRV grupā $(5,4 \% v s$ 1,2 \%), bet atškirība starp grupām nebija statistiski ticama (3.2. tabula).

3.2. tabula

Izdz̄ivotības rādītāji pacientiem ar sinhronu mKRV un metahronu mKRV

\begin{tabular}{|l|c|c|c|c|c|}
\hline Izdzivotība & $\begin{array}{c}\text { Sinhrons } \\
\text { mKRV (n= } \\
\mathbf{1 4 3})\end{array}$ & $\begin{array}{c}\text { Metahrons } \\
\text { mKRV (n= 77) }\end{array}$ & $\mathbf{p}$ & HR & 95 \% KI \\
\hline mOS (mēn.) & 17 & 17 & 0,90 & 1,0182 & $0,7559-1,3714$ \\
\hline 1yOS (\%) & $69,10 \%$ & $62 \%$ & & & \\
\hline 2yOS & $22,80 \%$ & $20,30 \%$ & & & \\
5yOS & $1,2 \%$ & $5,4 \%$ & & & \\
\hline mPFS (mēn.) & 8 & 8 & 0,56 & 0,9 & $0,6440-1,2700$ \\
\hline 6mPFS & $60,8 \%$ & $59,4 \%$ & & & \\
\hline 1yPFS & $22,1 \%$ & $14,90 \%$ & & & \\
\hline
\end{tabular}

mOS - median overall survival (vidējā kopējā izdzīvotība); 1yOS - 1 year overall survival (1 gada kopējā izdzīvotība); mPFS - median progression free survival (vidējā bezprogresijas izdzīvotība); $6 \mathrm{mPFS}-6$ month progression free survival (6 mēnešu bezprogresijas izdzīvotība)

Izdzīvotība, atkarībā no saņemtā pirmās līnijas k,īmijterapijas veida, ir atspogul,ota 3.3. tabulā. Visgarākā mPFS (10 mēn.) konstatēta pacientiem, kas saṇēma FOLFOX ar monoklonālajām antivielām, bet īsākā mPFS (5 mēn.) - pacientiem, kas san̄ēma irinotekānu saturošu terapiju, bet datu atšķirība nebija statistiski ticama. Kopējā izdzīvotība būtiski neatšḳ̂̄āas starp dažādu terapiju saṇēmušo pacientu apakšgrupām. Sinhrona mKRV apakšgrupā 
visaugstākais mOS rādītājs bija pacientiem, kas san̄ēma FOLFOX ar monoklonālajām antivielām (24 mēn.), bet viszemākais - pacientiem, kas saṇēma fluoropirimidīnu monoterapiju (13 mēn.), bet atškirība nebija statistiski ticama.

3.3. tabula

Vidējā kopējā izdzīvotība un vidējā bezprogresijas izdzīvotība atkarībā no 1. līnijas ķīmijterapijas pacientiem ar sinhronu mKRV un metahronu mKRV

\begin{tabular}{|c|c|c|c|c|c|c|}
\hline $\begin{array}{l}\text { Pacientu } \\
\text { grupa }\end{array}$ & FOLFOX & $\begin{array}{c}\text { FOLFOX } \\
+ \\
\text { biologisiskā } \\
\text { terapija }\end{array}$ & $\begin{array}{c}\text { Fluoropirimidīnu } \\
\text { monopterapija }\end{array}$ & $\underset{\text { ox }}{\text { Tegafur }+}$ & $\begin{array}{c}\text { Iri } \\
\text { saturošā } \\
\text { terapija }\end{array}$ & $\mathbf{p}$ \\
\hline \multicolumn{7}{|l|}{ mPFS } \\
\hline Visi & 8 mēn. & 10 mēn. & 8 mēn. & 7 mēn. & 5 mēn. & 0,28 \\
\hline $\begin{array}{l}\text { Sinhrons } \\
\text { mKRV }\end{array}$ & 9 mēn. & 10 mēn. & 8 mēn. & 6 mēn. & 6 mēn. & 0,327 \\
\hline $\begin{array}{l}\text { Metahrons } \\
\text { mKRV }\end{array}$ & 8 mēn. & 8 mēn. & 5 mēn. & 7 mēn. & 5 mēn. & 0,617 \\
\hline \multicolumn{7}{|l|}{$\mathrm{mOS}$} \\
\hline Visi & 18 mēn. & 16 mēn. & 13 mēn. & 18 mēn. & 14 mēn. & 0,415 \\
\hline $\begin{array}{l}\text { Sinhrons } \\
\text { mKRV }\end{array}$ & 18 mēn.. & 24 mēn. & 13 mēn. & 18 mēn. & 14 mēn. & 0,09 \\
\hline $\begin{array}{l}\text { Metahrons } \\
\text { mKRV }\end{array}$ & 18 mēn & 8 mēn. & 11 mēn. & 16 mēn. & 11 mēn. & 0,17 \\
\hline
\end{tabular}

mOS - median overall survival (vidējā kopējā izdzīvotība); mPFS - median progression free survival (vidējā bezprogresijas izdzīvotība); ox - oksalplatīns, iri - irinotekāns

No 125 pacientiem, kas saṇēma otrās līnijas ķīmijterapiju, 114 pacientiem bija zināms progresijas datums. Vidējā bezprogresijas izdzīvotība (mPFS2) visiem pacientiem $(n=114)$ bija 6 mēneši, 3 mēn. PFS2 - 74,9 \%, bet 6 mēn. PFS2 - 40,6 \%. Statistiski ticama mPFS2 atškirība tika konstatēta metahrona mKRV apakšgrupā.

Kopējā izdzīvotība bija labāka pacientiem, kas saṇēma otrās līnijas kīmijterapiju - gan sinhrona mKRV, gan metahrona mKRV apakšgrupā (3.4. tabula). Pacientiem, kas bija saṇēmuši otrās līnijas k,īmijterapiju $(n=125)$, mOS bija 20 mēn., salīdzinot ar mOS 11 mēn. pacientiem, kas terapiju neturpināja (HR 0,36, p < 0,0001) (3.7. att.). 5 gadu OS bija $3,8 \%$ vs $0 \%$. 
3.4. tabula

Dzīvildzes salīdzinājums pacientiem, kas ir vai nav saṇēmuši otrās līnijas k̦īmijterapiju

\begin{tabular}{|c|c|c|c|c|c|}
\hline Grupa & $\begin{array}{l}\text { 2. līniju ir } \\
\text { sanẹēmuši }\end{array}$ & $\begin{array}{l}\text { 2. līniju nav } \\
\text { saṇēmuši }\end{array}$ & $\mathbf{p}$ & HR & $95 \% \mathrm{KI}$ \\
\hline \multicolumn{6}{|l|}{ Kopējā izdzīvotība } \\
\hline $\begin{array}{l}\mathrm{mOS} \\
1 \mathrm{yOS} \\
2 \mathrm{yOS} \\
5 \mathrm{yOS}\end{array}$ & $\begin{array}{c}20 \text { mēn. } \\
83 \% \\
36,2 \% \\
3,8 \%\end{array}$ & $\begin{array}{c}11 \text { mēn. } \\
43,5 \% \\
7,8 \% \\
0 \%\end{array}$ & $<0,0001$ & 0,3658 & $\begin{array}{c}0,2636- \\
0,5075\end{array}$ \\
\hline $\begin{array}{l}\text { mOS sinhrona } \\
\text { mKRV grupā }\end{array}$ & 20 mēn. & 11 mēn. & $\mathbf{0 , 0 0 1 7}$ & 0,4414 & $\begin{array}{c}0,264- \\
0,726\end{array}$ \\
\hline $\begin{array}{c}\text { mOS metahrona } \\
\text { mKRV grupā }\end{array}$ & 21 mēn. & 11,5 mēn. & $<0,0001$ & 0,286 & $\begin{array}{c}0,184- \\
0,444\end{array}$ \\
\hline \multicolumn{6}{|c|}{ Bezprogresijas izdzīvotība } \\
\hline $\operatorname{mPFS} 2(n=114)$ & 6 mēn. & - & & & \\
\hline $\begin{array}{l}3 \mathrm{mPFS} 2 \\
6 \mathrm{mPFS} 2 \\
\end{array}$ & $\begin{array}{l}74,90 \% \\
40,60 \% \\
\end{array}$ & & & & \\
\hline
\end{tabular}

mOS - median overall survival (vidējā kopējā izdzīvotība); 1yOS - 1 year overall survival (1 gada kopējāā izdzīvotība); mPFS2 - median progression free survival (vidējā bezprogresijas izdzīvotība); 6mPFS2 - 6 month progression free survival ( 6 mēnešu bezprogresijas izdzīvotība)

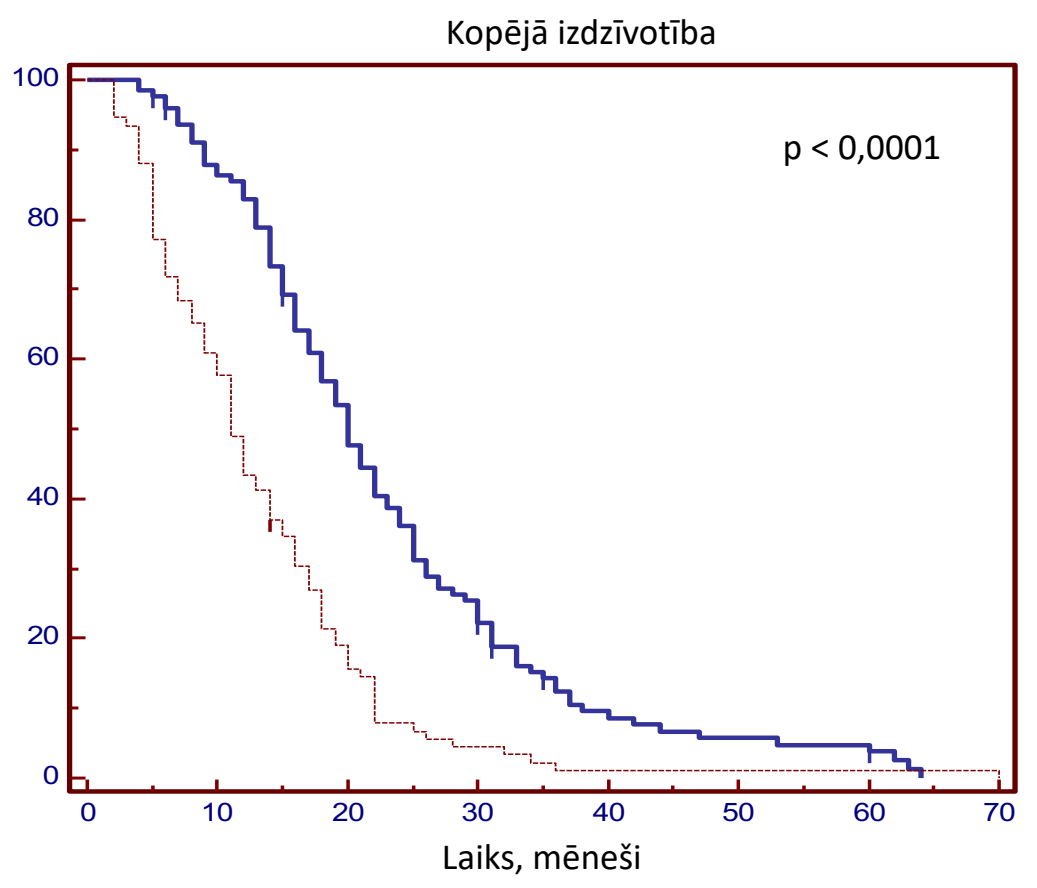

\section{7. att. Kaplana-Maijera kopējās izdzīvotības (OS) līkne pacientiem, kas saṇēma 2. līnijas kīmijterapiju, salīdzinājumā ar tiem, kas nesañēma}

HR 0,36; 95 \%KI 0,26-0,51; p < 0,0001. mOS 20 mēn. vs 11 mēn. Tumši zilā līnija - terapiju ir saņēmuši, sarkanā līnija - terapiju nav saṇēmuši

Izdzīvotība, atkarībā no saṇemtā otrās līnijas terapijas veida, atspogulota 3.5. tabulā. Visīsākais vidējais laiks līdz progresijai tika novērots pacientiem, kas saṇēma fluoropirimidīnu monoterapiju (4 mēn.). Statistiski nozīmīga atškirīība starp apakšgrupām tika konstatēta metahrona mKRV grupā. Visgarākā vidējā kopējā izdzīvotība konstatēta pacientiem, kas saṇēma FOLFIRI ar monoklonālajām antivielām: 35 mēneši kopējā grupā ( $<$ 0,0001), 
38 mēneši sinhrona mKRV grupā $(p<0,0001)$ un 30 mēneši metahrona mKRV grupā $(\mathrm{p}=0,03)$.

3.5. tabula

Vidējā kopējā izdzìvotība (mOS) un vidējā bezprogresijas izdzīvotība (mPFS2) atkarībā no otrās līnijas k̦īmijterapijas veida

\begin{tabular}{|c|c|c|c|c|c|c|}
\hline Grupa & FOLFIRI & $\begin{array}{c}\text { FOLFIRI } \\
\text { + mab }\end{array}$ & $\begin{array}{c}\text { Fluoropirimidīni } \\
\text { monoterapijā }\end{array}$ & $\begin{array}{c}\text { Oksaliplatīnu } \\
\text { saturošas } \\
\text { shēmas }\end{array}$ & $\begin{array}{c}\text { Nesan̄ēma } \\
\mathbf{2} \text { lin̄ijas } \\
\text { terapiju }\end{array}$ & p \\
\hline mPFS & \multicolumn{5}{|l|}{} \\
\hline Visi & 5 mēn. & 8 mēn. & 4 mēn. & 10 mēn. & na & 0,49 \\
\hline $\begin{array}{c}\text { Sinhrons } \\
\text { mKRV }\end{array}$ & 5 mēn. & 8 mēn. & 7,5 mēn. & 10 mēn. & na & 0,749 \\
\hline $\begin{array}{c}\text { Metahrons } \\
\text { mKRV }\end{array}$ & 6 mēn & 12 mēn & 3,5 mēn & na & na & $\mathbf{0 , 0 4 2}$ \\
\hline mOS & 19 mēn. & 35 mēn. & 20 mēn. & 20 mēn. & 11 mēn. & $<\mathbf{0 , 0 0 0 1}$ \\
\hline Visi & 19 mēn. & 38 mēn. & 19 mēn. & 20 mēn. & 11 mēn. & $<\mathbf{0 , 0 0 0 1}$ \\
\hline $\begin{array}{c}\text { Sinhrons } \\
\text { mKRV }\end{array}$ & 21 mēn. & 30 mēn. & 21,5 mēn. & na & 11,5 mēn. & $\mathbf{0 , 0 3}$ \\
\hline $\begin{array}{c}\text { Metahrons } \\
\text { mKRV }\end{array}$ &
\end{tabular}

mOS - median overall survival (vidējā kopējā izdzīvotība); mPFS2 - median progression free survival (vidējā bezprogresijas izdzīvotība)

Analizējot pacientus dažādās vecuma grupās, tika konstatēts, ka gados jauniem pacientiem (< 50 gadiem) bija labāka gan vidējā kopējā izdzīvotība (30 mēn. vs 16 mēn., $\mathrm{p}=0,0002)$, gan vidējā bezprogresijas izdzīvotība (9 mēn. vs 8 mēn., $\mathrm{p}=0,045$ ). 5 gadu kopèjā izdzīvotība < 50 gadu grupā sasniedza 18,8 \%, salīdzinot ar 0,8 \% pacientiem $\geq 50$ gadu grupā (3.6. tabula). Atsevišḳi izdalot $<40$ gadus vecus pacientus $(n=6)$, tika konstatēti līdzīgi rezultāti - mOS 33 mēn. vs 16 mēn. ( $\mathrm{p}=$ 0,0109; HR 0,4244; 95 \%KI 0,2195-0,8207).

3.6. tabula

Izdzīvotības rādītāji atkarībā no pacienta vecuma

\begin{tabular}{|l|c|c|c|c|c|}
\hline Izdzìvotība & < 50 gadi $(\mathbf{n = 2 8})$ & $\mathbf{z ~ 5 0 ~ g a d i ~}$ & $\mathbf{p}$ & HR & $\mathbf{9 5}$ \% KI \\
\hline mOS & 30 mēn. & 16 mēn. & $\mathbf{0 , 0 0 0 2}$ & 0,498 & $0,3453-0,7184$ \\
\hline 1yOS & $77,8 \%$ & $65 \%$ & & & \\
2yOS & $51,2 \%$ & $21,8 \%$ & & & \\
5yOS & $18,8 \%$ & $0,8 \%$ & & & \\
\hline mOS 2004.-2011. & 20 mēn. & 15 mēn. & $\mathbf{0 , 0 0 5 5}$ & 0,4944 & $0,3008-0,8128$ \\
mOS 2012.-2016. & 31 mēn. & 17 mēn. & $\mathbf{0 , 0 0 3 6}$ & 0,4465 & $0,2593-0,7688$ \\
\hline mPFS & 9 mēn. & 8 mēn. & $\mathbf{0 , 0 4 5}$ & 0,647 & $0,4225-0,9901$ \\
\hline mPFS 2004.-2011. & 7 mēn. & 8 mēn. & 0,1862 & 0,6474 & $0,3398-1,2334$ \\
mPFS 2012.-2016. & 9 mēn. & 7 mēn. & 0,1643 & 0,6664 & $0,3762-1,1807$ \\
\hline
\end{tabular}

mOS - median overall survival (vidējā kopējā izdzīvotība); 1yOS - 1 year overall survival (1 gada kopējā izdzīvotība); mPFS - median progression free survival (vidējā bezprogresijas izdzīvotība) 


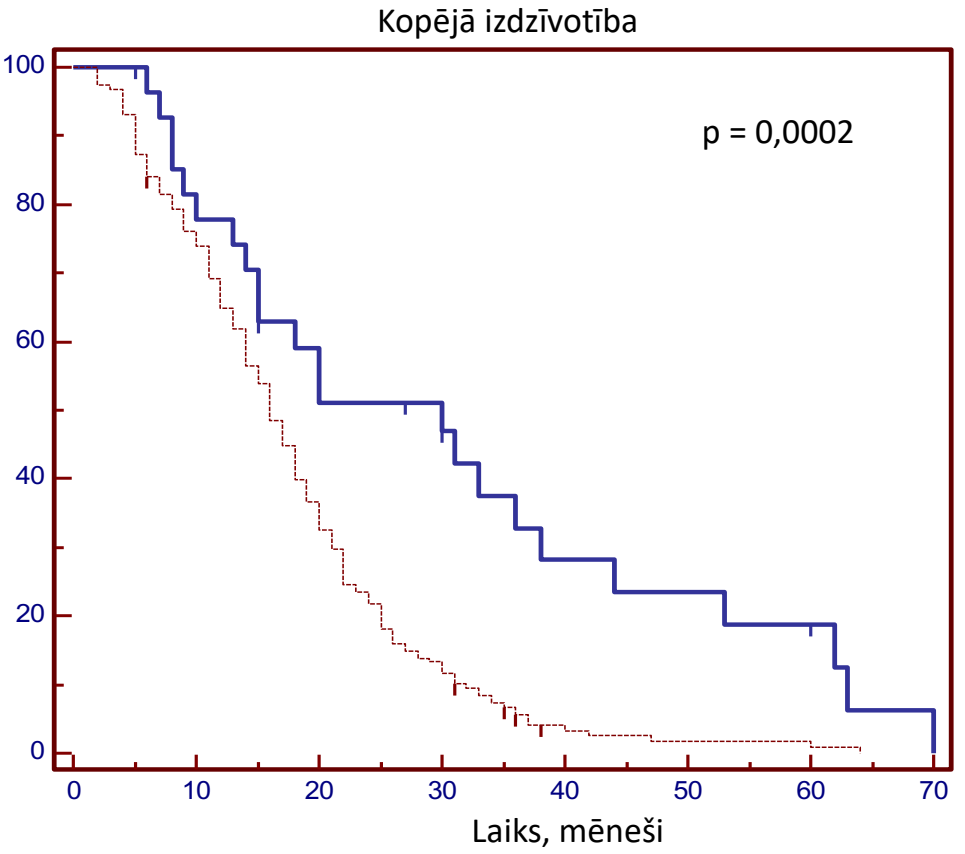

\section{8. att. Kaplana-Meijera kopējās izdzīvotības (OS) līkne pacientiem, kas jaunāki par 50 gadiem,} salīdzinot ar vecākiem pacientiem

mOS 30 mēn. vs 16 mēn., HR 0,49; 95 \%KI 0,34-0,72; p = 0,0002. Tumši zilā līnija $-<50$ gadiem, sarkanā linija $-\geq 50$ gadiem

Analizējot PFS un OS pacientiem, kas saṇēma ārstēšanu atškirīgos laika nogriežn,os (2004.-2011. vai 2012.-2016.), statistiski ticama atšķirība starp grupām netika konstatēta (3.7. tabula). Labāka mOS, 1 gada OS un 2 gadu OS bija pacientiem, kas terapiju saṇēma pēc 2012. gadā, bet statistiskā ticamība netika sasniegta (3.9. attēls).

Dzīvildzes rādītāji atkarībā no diagnosticēšanas gada

\begin{tabular}{|c|c|c|c|c|c|}
\hline Izdzīvotība & $\begin{array}{c}\text { 2004.-2011.gads } \\
n=106\end{array}$ & $\begin{array}{c}2012 .-2016 . \text { gads } \\
n=114\end{array}$ & $\mathbf{p}$ & HR & $95 \% \mathrm{KI}$ \\
\hline mPFS & 8 mēn. & 8 mēn. & 0,95 & 1,0097 & $0,7405-1,3769$ \\
\hline $\begin{array}{l}6 \mathrm{mPFS} \\
12 \mathrm{mPFS}\end{array}$ & $\begin{array}{l}63,5 \% \\
17,1 \%\end{array}$ & $\begin{array}{c}57,6 \% \\
24 \%\end{array}$ & & & \\
\hline $\mathrm{mOS}$ & 16 mēn. & 18 mēn. & 0,1036 & 1,2679 & $0,9527-1,6873$ \\
\hline $\begin{array}{l}1 \mathrm{yOS} \\
2 \mathrm{yOS} \\
5 \mathrm{yOS}\end{array}$ & $\begin{array}{c}63 \% \\
19,8 \% \\
2,9 \%\end{array}$ & $\begin{array}{c}70 \% \\
30,1 \% \\
2,7 \%\end{array}$ & & & \\
\hline
\end{tabular}

mOS - median overall survival (vidējā kopējā izdzīvotība); 1yOS - 1 year overall survival (1 gada kopējā izdzīvotība); mPFS - median progression free survival (vidējà bezprogresijas izdzīvotīiba); $6 \mathrm{mPFS}-6$ month progression free survival ( 6 mēnešu bezprogresijas izdzīvotība) 


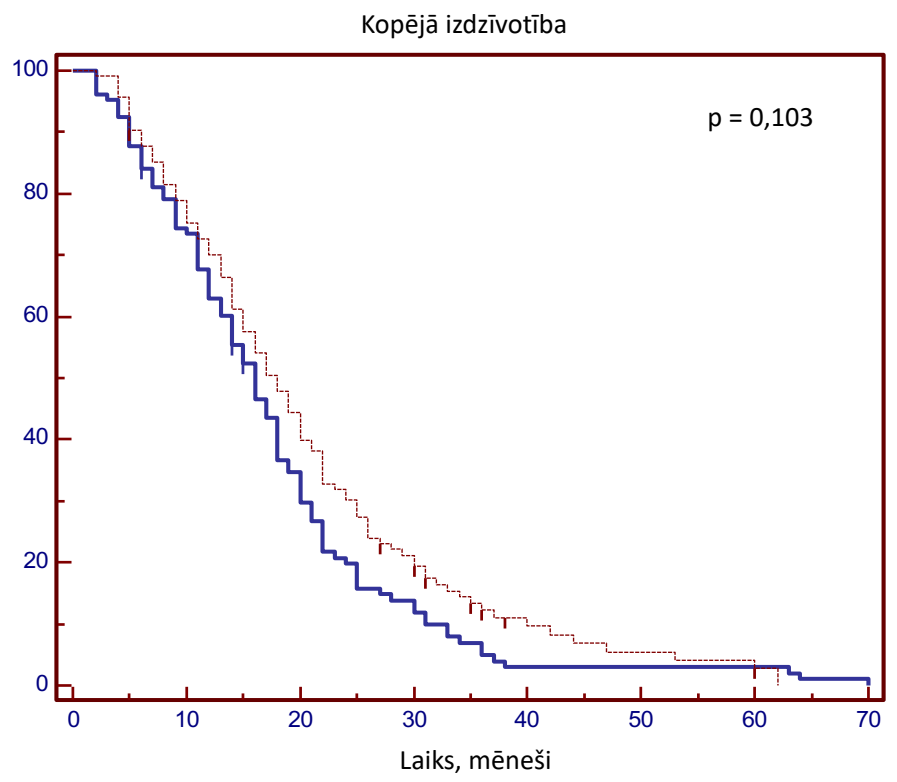

3.9. att. Kaplana-Meijera kopējās izdzīvotības līkne pacientiem, kas ārstējās klīnikā no 2004. g.

lìdz 2011. g., salīdzinot ar pacientiem, kas terapiju saṇēma laikā no 2012. g. līdz 2017. g.

mOS 16 mēn. vs 18 mēn, HR 1,27; 95 \%KI 0,95-1,68; p = 0,103. Tumši zilā līnija: 2004. g.-2011. g., sarkanā līnija: 2012. g.-2016. g.

Izdzīvotības rādītāji bija sliktāki pacientiem, kuriem diagnosticēšanas brīdī bija multiplas metastāzes vairākos orgānos: mPFS 8 mēn un mOS 14,5 mēn (3.8. tabula.). Vislielākā grupa bija pacienti ar aknu metastāzēm $(n=92)$, šajā grupā mPFS bija 8 mēn., bet mOS - 17 mēn.

3.8. tabula

Izdzìvotības rādītāji (PFS un OS) atkarībā no metastāžu lokalizācijas vietas

\begin{tabular}{|l|c|c|c|c|c|}
\hline Izdzīvotība & Aknu mts & Plaušu mts & $\begin{array}{c}\text { Vēdera dob. } \\
\text { vai l/mts }\end{array}$ & $\begin{array}{c}\text { Multiplas } \\
\text { mts }\end{array}$ & p \\
\hline mPFS & 8 mēn. & 11 mēn & 9 mēn. & 8 mēn. & 0,1494 \\
6mPFS & $59,9 \%$ & $78,1 \%$ & $62,3 \%$ & $55,5 \%$ & \\
12mPFS & $19,4 \%$ & $34,7 \%$ & $30 \%$ & $14 \%$ & \\
\hline mOS & 17 mēn. & 20 mēn. & 18 mēn. & 14,5 mēn. & $\mathbf{0 , 0 4 2 4}$ \\
1yOS & $74,8 \%$ & $73,7 \%$ & $71 \%$ & $56,2 \%$ & \\
2yOS & $24 \%$ & $26,8 \%$ & $38,7 \%$ & $14,6 \%$ & \\
5yOS & $3,4 \%$ & $0 \%$ & $0 \%$ & $0 \%$ & \\
\hline
\end{tabular}

mOS - median overall survival (vidējā kopējā izdzīvotība); 1yOS - 1 year overall survival (1 gada kopējā izdzīvotība); mPFS - median progression free survival (vidējā bezprogresijas izdzīvotība); $6 \mathrm{mPFS}-6$ month progression free survival (6 mēnešu bezprogresijas izdzīvotība)

Multifaktoriālā Cox regresijas analīze parāda, ka neatkarīgie prognostiskie rādītāji, kas ietekmē kopējo izdzīvotību, ir vecums un terapijas līniju skaits (3.9. tab). 
Daudzfaktoru analīze - dažādu faktoru ietekme uz kopējo izdzīvotību

\begin{tabular}{|c|c|c|c|c|c|}
\hline Faktors & $\mathbf{b}$ & SD & $\mathbf{p}$ & HR & $\mathbf{9 5}$ \%KI \\
\hline $\begin{array}{c}\text { Laika periods (2004.-2011. vs } \\
\text { 2012.-2016.) }\end{array}$ & 0,0005504 & 0,1558 & 0,9972 & 1,00 & $0,73-1,35$ \\
\hline Metastāžu veids & 0,0787 & 0,04517 & 0,08148 & 1,08 & $0,99-1,18$ \\
\hline Terapijas līniju skaits $(1 v s>1)$ & 1,0717 & 0,4835 & $\mathbf{0 , 0 2 6 6 7}$ & $\mathbf{2 , 9 2}$ & $1,13-7,49$ \\
\hline Vecums ( $>50 \mathrm{~g} v s<50)$ & 0,7793 & 0,2446 & $\mathbf{0 , 0 0 1 4 4}$ & $\mathbf{2 , 1 7}$ & $1,35-3,51$ \\
\hline 2. līnijas terapijas veids & $-0,0762$ & 0,131 & 0,5608 & 0,92 & $0,71-1,19$ \\
\hline
\end{tabular}

SD - Standarta deviācija, HR - hazard ratio (riska attiecība), 95 \%KI - 95 \% konfidences intervāls

\subsection{Klīnisko prognostisko un prediktīvo faktoru analīze mKRV pacientiem, kas saṇem FTD/TPI}

14 pacienti tika iekḷauti Lonsurf pirmsreǵistrācijas pacientu atbalsta programmā 2016. g. aprīlī un saņēma ārstēšanu no 2016. gada aprīḷa līdz 2017. gada janvārim divās Latvijas slimnīcās. Visi pacienti bija iepriekš saṇēmuši 2-4 ķīmijterapijas līnijas. Pacienti saņēma FTD/TPI $35 \mathrm{mg} / \mathrm{m}^{2}$ devā 1-9 kursus (vidēji 5,8 kursus). Pacientu klīniskie dati apkopoti 3.10. tabulā.

FTD/TPI pacientu klīniskie dati $(n=14)$

\begin{tabular}{|l|l|}
\hline Parametrs & Biežums (\%) \\
\hline Vecums, gados & $65(52-76)$ \\
\hline Dzimums: & $6(42,8 \%)$ \\
Vīrieši & $8(57,2 \%)$ \\
Sievietes & $5(35,7 \%)$ \\
\hline ECOG & $9(64,3 \%)$ \\
0 & \\
1 & $9(64,3 \%)$ \\
\hline Primārā audzēja lokalizācija & $5(35,7 \%)$ \\
Resnā zarna & \\
Taisnā zarna & $1(7,1 \%)$ \\
\hline KRAS & $4(28,6 \%)$ \\
Wt & $9(64,3 \%)$ \\
Mut & \\
nezināms & $8(57,2 \%)$ \\
\hline Metastāzes & $6(42,8 \%)$ \\
Sinhronas - IV stadijas vēzis & 22 mēneši (8-36) \\
Metahronas & \\
$\quad$ Vidējais laiks līdz metastāžu atklāšanai & \\
$\quad$ II stadija -1 & \\
$\quad$ III stadija - 5 & \\
\hline
\end{tabular}


3.10. tabulas turpinājums

\begin{tabular}{|c|c|}
\hline Parametrs & Biežums (\%) \\
\hline $\begin{array}{l}\text { Vidējais laiks no pirmās ḳimijterapijas līnijas uzsākšanai līdz } \\
\text { iekļaušanai pētījumā } \\
\quad>18 \text { mēneši } \\
\quad \leq 18 \text { mēneši }\end{array}$ & $\begin{array}{l}32,2 \text { mēneši }(8-90) \\
9(64,3 \%) \\
5(35,7 \%)\end{array}$ \\
\hline Iepriekš sanemto kīmijterapijas līniju skaits & $2,7(2-4)$ \\
\hline Iepriekš saņemtie ķīmijterapijas medikamenti: & \\
\hline $5 \mathrm{FU}$ & $14(100 \%)$ \\
\hline Ftorafūrs & $3(21,4 \%)$ \\
\hline Kapecitabīns & $3(21,4 \%)$ \\
\hline Oksaliplatīns & $13(92,8 \%)$ \\
\hline Irinotekāns & $14(100 \%)$ \\
\hline Bevacizumabs & $6(42,8 \%)$ \\
\hline Aflibercepts & $1(7,1 \%)$ \\
\hline Cetuksimabs & $1(7,1 \%)$ \\
\hline
\end{tabular}

Vienam pacientam ārstēšana tika pārcelta par 1 nedēḷ 3. pakāpes neitropēnijas dēḷ. Nevienam no pacientiem netika samazināta medikamenta deva. Visiem pacientiem ārstēšana tika pārtraukta slimības progresijas dēḷ.

$4(28,5 \%)$ pacientiem terapijas laikā attīstījās 3.-4. pakāpes neitropēnija, vienam pacientam $(7,1 \%)$ caureja, bet škebināšana novērota $5(35,7 \%)$ pacientiem.

Pētījumā iekḷautajiem pacientiem mPFS bija 5 mēneši (95 \%KI 4,09-5,90), bet mOS bija 7 mēneši (95 \%KI 5,95-8,04). 6 mēnešu PFS bija 35,7 \%, bet 6 mēnešu OS - 57,1 \%. Visiem 14 pacientiem konstatēta progresija, bet 9 pacienti pêtījuma laikā mira.

Pagarināta PFS un OS tika konstatēta pacientiem ar 3.-4. pakāpes neitropēniju: pacientiem ar neitropēniju mPFS bija 7 mēneši, salīdzinot ar 5 mēnešiem pacientiem ar normālu neitrofīlo leikocītu skaitu (HR 0,24; $95 \%$ KI 0,07-0,89; p =0,033); pacientiem ar normālu leikocītu skaitu mOS bija 7 mēneši, bet pacientiem ar neitropēniju mOS rādītājs netika sasniegts (HR 0,25; $95 \% \mathrm{KI} 0,06-1,14 ; \mathrm{p}=0,075)$ (3.10. attēls).

Analizējot iepriekš saṇemtās terapijas ilgumu, tika konstatēts, ka pacientiem, kuri pētījumā tika iekḷauti > 18 mēnešus no metastātiska kolorektālā vēža diagnosticēšanas brīža, bija garāks PFS un OS. mPFS bija 7 mēneši pacientiem ar garo intervālu, bet pacientiem ar intervālu $\leq 18$ mēnešiem līdz iekḷaušanai pētījumā - 5 mēneši (HR 0,15; $95 \%$ KI 0,03-0,83; $\mathrm{p}=0,029)$. Vidējā kopējā dzīvildze netika sasniegta pacientu grupā ar intervālu $>18$ mēn., bet otrā grupā tā bija 6 mēneši (HR 0,23; $95 \% \mathrm{KI}$ : 0,05-1,12; p = 0,069) (3.11. attēls). 

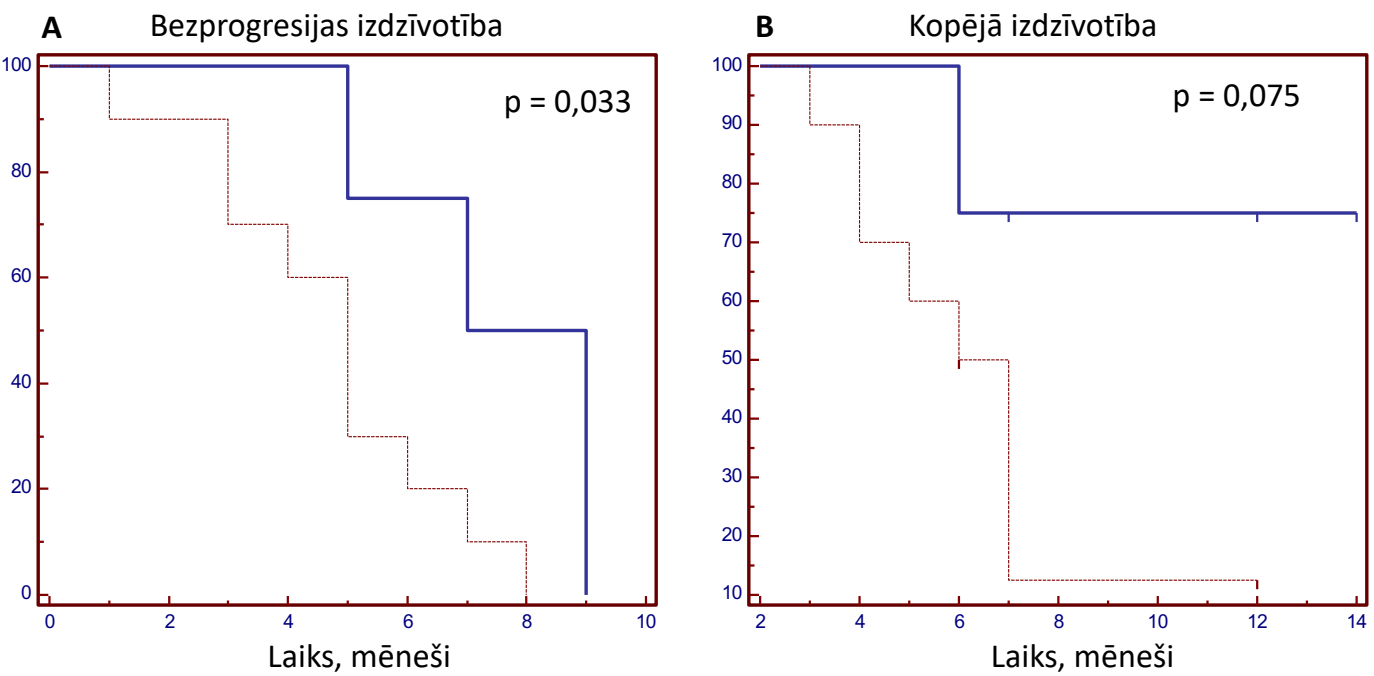

3.10. att. 3.-4. pakāpes neitropēnija kā prognostiskais un prediktīvais faktors pacientiem ar metastātisku kolorektālo vēzi

(A) mPFS pacientiem ar neizmainītu neitrofìlo leikocītu skaitu bija 5 mēn. vs 7 mēn. pacientiem ar neitropēniju (HR 0,24; $95 \% \mathrm{KI} 0,07-0,89 ; \mathrm{p}=0,033$ ). (B) mPOS pacientiem ar neizmainītu neitrofìlo leikocītu skaitu bija 7 mēn., bet pacientiem ar neitropēniju mOS netika sasniegta (HR 0,25; $95 \% \mathrm{KI} 0,06-1,14 ; \mathrm{p}=0,075$ )
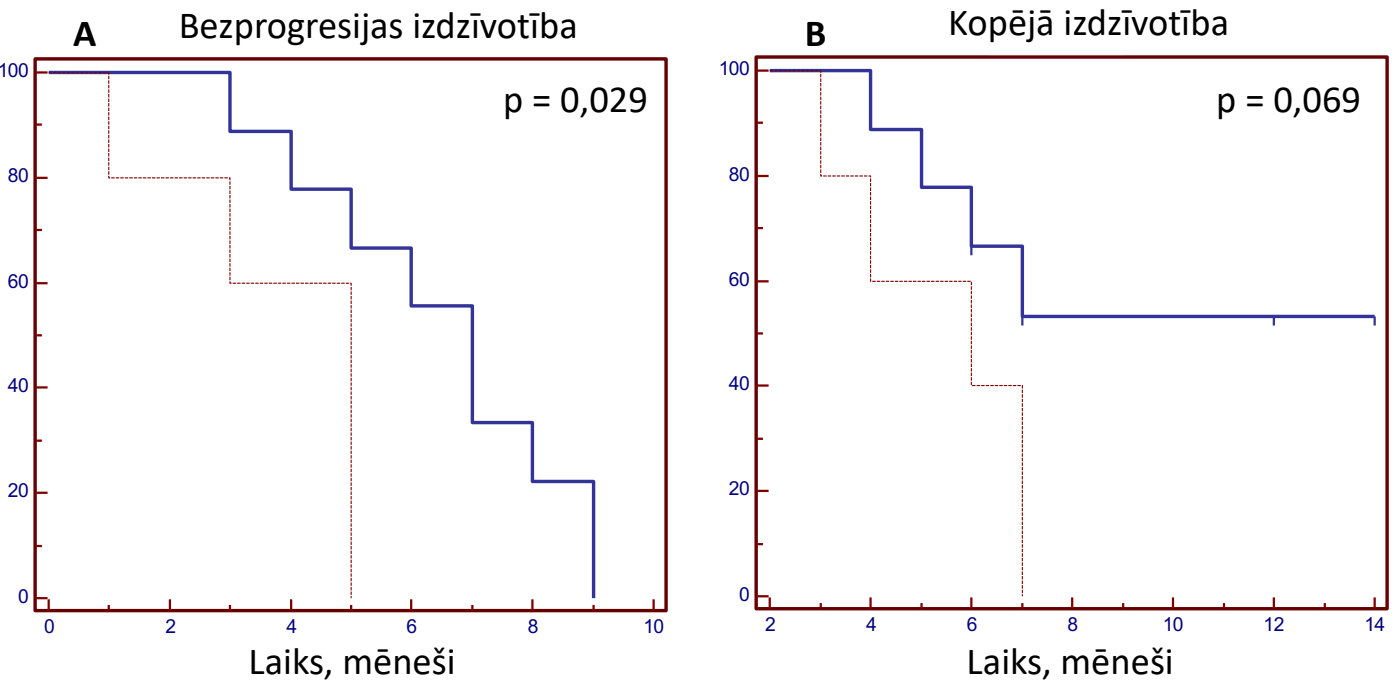

3.11. att. Iepriekšējās ārstēšanas ilgums kā prognostiskais un prediktīvais faktors pacientiem ar metastātisku kolorektālo vēzi

(A) mPFS pacientiem ar $>18$ mēn. no pirmās līnijas kīmijterapijas uzsākšanas - 7 mēn. vs 5 mēn. pacientiem ar laika intervālu $\leq 18$ mēn (HR 0,15; $95 \% \mathrm{KI} 0,03-0,83 ; \mathrm{p}=0,029)$. (B) mOS pacientiem ar $\leq 18$ mēn. no pirmās līnijas ķ̄imijterapijas uzsākšanas -6 mēn., bet pacientiem ar laika intervālu $>18$ mēn. mOS netika sasniegts (HR $0,23 ; 95 \% \mathrm{KI} 0,05-1,12 ; \mathrm{p}=0,069)$

\subsection{Chromothripsis kā metastātiska kolorektālā vēža prediktīvais faktors}

19 pacienti saṇēma paliatīvu pirmās līnijas ḳīmijterapiju Paula Stradiṇa Klīniskās universitātes slimnīcas Onkolog̣ijas klīnikā no 2011. gada augusta līdz 2012. gada oktobrim. Tika veikta kopiju skaita variāciju analīze. Pacientu klīniskie un demogrāfiskie dati atainoti 
3.10. tabulā. Pacientu novērošanas ilgums bija vidēji 25,5 mēneši (3-48 mēneši), novērošana veikta līdz 2016. gadam.

15 pacientiem bija primāri metastātisks vēzis (IV stadija), bet 4 pacientiem - sekundāri metastātisks audzējs ar metastātisku slimības izplatī̌anos pēc radikālas primārā audzēja ārstēšanas. 10 pacientiem konstatētas aknu metastāzes, pārējiem pacientiem metastāzes konstatētas vairākos orgānos. 16 pacientiem veikta primārā audzēja operācija, bet 3 pacientiem veikta biopsija. 7 pacientiem pirms ārstēšanas uzsākšanas karcinoembrionālais antigēns (KEA) asin̄̄s nebija paaugstināts $(\leq 5,5 \mathrm{ng} / \mathrm{ml})$.

Visi pacienti san,ēma pirmās līnijas FOLFOX tipa k,īmijterapiju, pēc progresijas 15 pacienti saṇēma otrās līnijas irinotekānu saturošu k,īmijterapiju, 1 pacientam atsākta iepriekšējā FOLFOX k̦īmijterapija, 1 pacients saṇēma fluoropirimidīnu monoterapiju ar Ftorafur (Tegafur) un divi pacienti turpināja simptomātisku terapiju un aprūpi. Tikai pieci pacienti $(26,3 \%)$ saṇēma trešās līnijas paliatīvo kīmijterapiju (irinotekāns, oksaliplatīns vai Ftorafur monoterapijā).

Vienam pacientam pēc otrās līnijas k,īmijterapijas saņemšanas veikta aknu metastāžu rezekcija, 2 pacientiem veikta transarteriāla k,īmijembolizācija (TACE), izmantojot ar irinotekānu pild̄̄tas mikrosfēras, vienam pacientam veikta paliatīva staru terapija lokālajam audzējam taisnajā zarnā.

Pacientu klīnisko rādītāju raksturojums $(\mathrm{n}=19)$

\begin{tabular}{|l|l|}
\hline Parametrs & Biežums (\%) \\
\hline Vecums & 63,15 gadi (38-78) \\
\hline Dzimums: & $11(57,89 \%)$ \\
Vīrieši & $8(42,11 \%)$ \\
Sievietes & $11(57,89 \%)$ \\
\hline Audzēja lokalizācija: & \\
Kreisā puse - lejupejošās, sigmveida zarnas un taisnās & \\
zarnas vēzis & $8(42,11 \%)$ \\
Labā puse - augšupejošās un škēerszarnas vēzis & $1(5,26 \%)$ \\
\hline Diferenciācijas pakāpe: & $13(68,42 \%)$ \\
Nezināma & $5(26,32 \%)$ \\
G2 & $15(78,95 \%)$ \\
G3 & $4(21,05 \%)$ \\
\hline $\begin{array}{l}\text { Metastāzes: } \\
\text { Sinhronas }\end{array}$ & \\
Metahronas & \\
vidējais laiks līdz metastāžu diagnosticēšanai 12,25 & \\
mēneši (9-18) & \\
$\quad$ II stadija -3 pacienti & \\
\hline III stadija -1 pacients & \\
\hline
\end{tabular}


3.11. tabulas turpinājums

\begin{tabular}{|l|l|}
\hline Parametrs & Biežums (\%) \\
\hline Metastāzes: & $10(52,63 \%)$ \\
Tikai aknās & $9(47,37 \%)$ \\
Vairākos orgānos & $10(52,64 \%)$ \\
\hline KRAS mutācija: & $7(36,84 \%)$ \\
Wild type (mutācijas nav) & $1(5,26 \%)$ \\
Mutācija 12. kodonā & $1(5,26 \%)$ \\
Mutācija 13. kodonā & \\
Nav datu & $7(36,84 \%)$ \\
\hline Seruma KEA līmenis pirms ārstēšanas: & $12(63,16 \%)$ \\
KEA $\leq 5,5$ ng/ml & $232,1(7,1-959,8)$ \\
KEA > 5,5 ng/ml & $25,5(3-48)$ \\
KEA līmenis, ng/ml & \\
\hline Vidējais novērošanas ilgums (mēneši) & \\
\hline
\end{tabular}

Kopējais vēža genoma lūzumpunktu skaits vienā audzēja paraugā (lūzumpunktu nestabilitātes indekss, LPI) ir 368-4009. Vislielākais LPI konstatēts 1. hromosomā (27-365), 2. hromosomā (25-315) un 6. hromosomā (22-298), bet vismazākais LPI - 21. hromosomā (7 - 99) (3.12. tabula).

10 pacientiem (52,6 \%) novērots chromothripsis (> 100 lūzumpunkti vienā hromosomā), tas visbiežāk konstatēta 1., 2. un 6. hromosomā. Vienam pacientam (nr. 14) tika konstatēts chromothripsis 20 hromosomās.

Netika konstatēta lūzumpunktu indeksa un chromothripsis korelācija ar vēža primāro lokalizāciju (resnās zarnas vēzis vai taisnās zarnas vēzis), KEA līmeni asinīs pirms terapijas uzsākšanas, KRAS stāvokli audzēja šūnās, slimības stadiju (sinhrons metastātisks vēzis (IV stadija) vs metahrons metastātisks vēzis).

Lūzumpunktu skaits hromosomās un chromothripsis

\begin{tabular}{|l|c|c|}
\hline Hromosoma & $\begin{array}{c}\text { Lūzumpunktu skaits, } \\
\text { n (vidējais) }\end{array}$ & $\begin{array}{c}\text { Chromothripsis } \\
\text { > 100 lūzumpunkti, } \\
\text { pacientu skaits (\%) }\end{array}$ \\
\hline Chr. 1 & $27-365(150,2)$ & $10(52,6)$ \\
\hline Chr. 2 & $25-315(136,8)$ & $10(52,6)$ \\
\hline Chr. 3 & $21-234(94,5)$ & $7(36,8)$ \\
\hline Chr. 4 & $10-232(73,9)$ & $5(26,3)$ \\
\hline Chr. 5 & $20-189(87,1)$ & $5(26,3)$ \\
\hline Chr. 6 & $22-298(118,9)$ & $10(52,6)$ \\
\hline Chr. 7 & $16-195(82,7)$ & $5(26,3)$ \\
\hline Chr. 8 & $16-199(81,6)$ & $5(26,3)$ \\
\hline Chr. 9 & $11-205(79,2)$ & $5(26,3)$ \\
\hline Chr. 10 & $21-275(106,8)$ & $7(36,8)$ \\
\hline Chr. 11 & $34-252(104,1)$ & $8(42,1)$ \\
\hline Chr. 12 & $18-206(84,2)$ & $6(31,6)$ \\
\hline
\end{tabular}


3.12.tabulas turpinājums

\begin{tabular}{|l|c|c|}
\hline Hromosoma & $\begin{array}{c}\text { Lūzumpunktu skaits, } \\
\text { n (vidējais) }\end{array}$ & $\begin{array}{c}\text { Chromothripsis } \\
\text { > 100 lūzumpunkti, } \\
\text { pacientu skaits (\%) }\end{array}$ \\
\hline Chr. 13 & $14-166(54,1)$ & $3(15,8)$ \\
\hline Chr. 14 & $12-152(58,6)$ & $4(21,1)$ \\
\hline Chr. 15 & $3-166(58,9)$ & $4(21,1)$ \\
\hline Chr. 16 & $9-158(60,5)$ & $4(21,1)$ \\
\hline Chr. 17 & $10-206(66,8)$ & $4(21,1)$ \\
\hline Chr. 18 & $10-149(50,5)$ & $2(10,5)$ \\
\hline Chr. 19 & $7-137(44,2)$ & $2(10,5)$ \\
\hline Chr. 20 & $9-124(42,3)$ & $2(10,5)$ \\
\hline Chr. 21 & $7-99(24,7)$ & 0 \\
\hline Chr. 22 & $4-131(37)$ & $1(5,3)$ \\
\hline
\end{tabular}

10 pacientu audu paraugos (52,6 \%) konstatēta multipla hromosomāla fragmentācija chromothripsis (> 100 lūzumpunktu vienā hromosomā). Visbiežāk chromothripsis konstatēts 1., 2. un 6. hromosomā $(52,6 \%$ ), visretāk - 21. hromosomā $(0 \%)$

Visaugstākais lūzumpunktu skaits bija pacientam nr. 14 - LPI 4009, vismazākais pacientam nr. 5 - LPI 368 (3.12. attēls). Pacientam nr. 14 tika konstatēts chromothripsis 20 hromosomās.

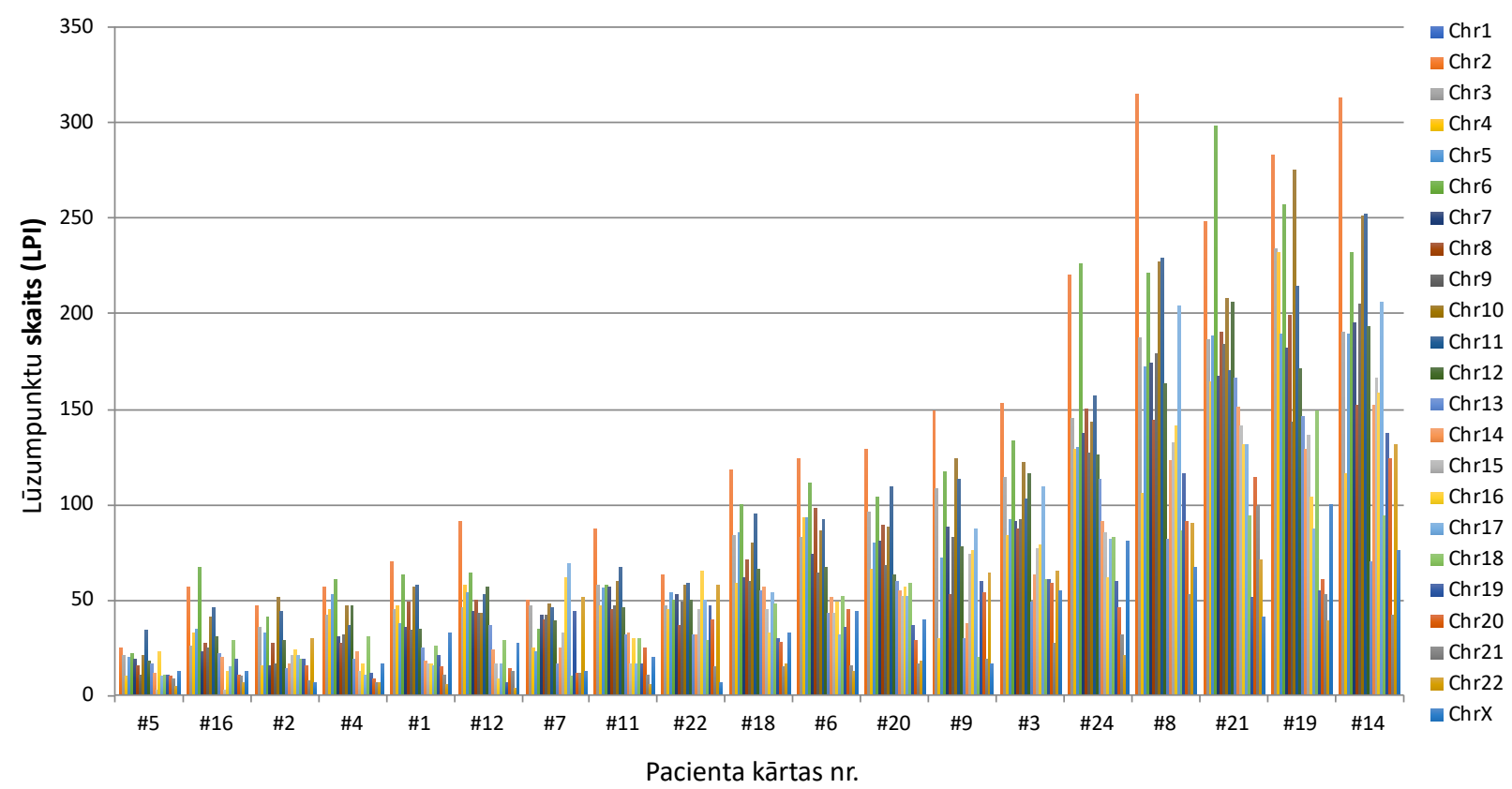

3.12. att. Kopējais lūzumpunktu skaits atšķirīgiem pacientiem

Hromosomās, kurās LPI ir > 100, ir konstatēts chromothripsis. Chr - hromosoma

Katra pacienta vēža audos tika analizētas visas hromosomas un atainotas grafiski 3.13. attēlā un 3.14. attēlā. 

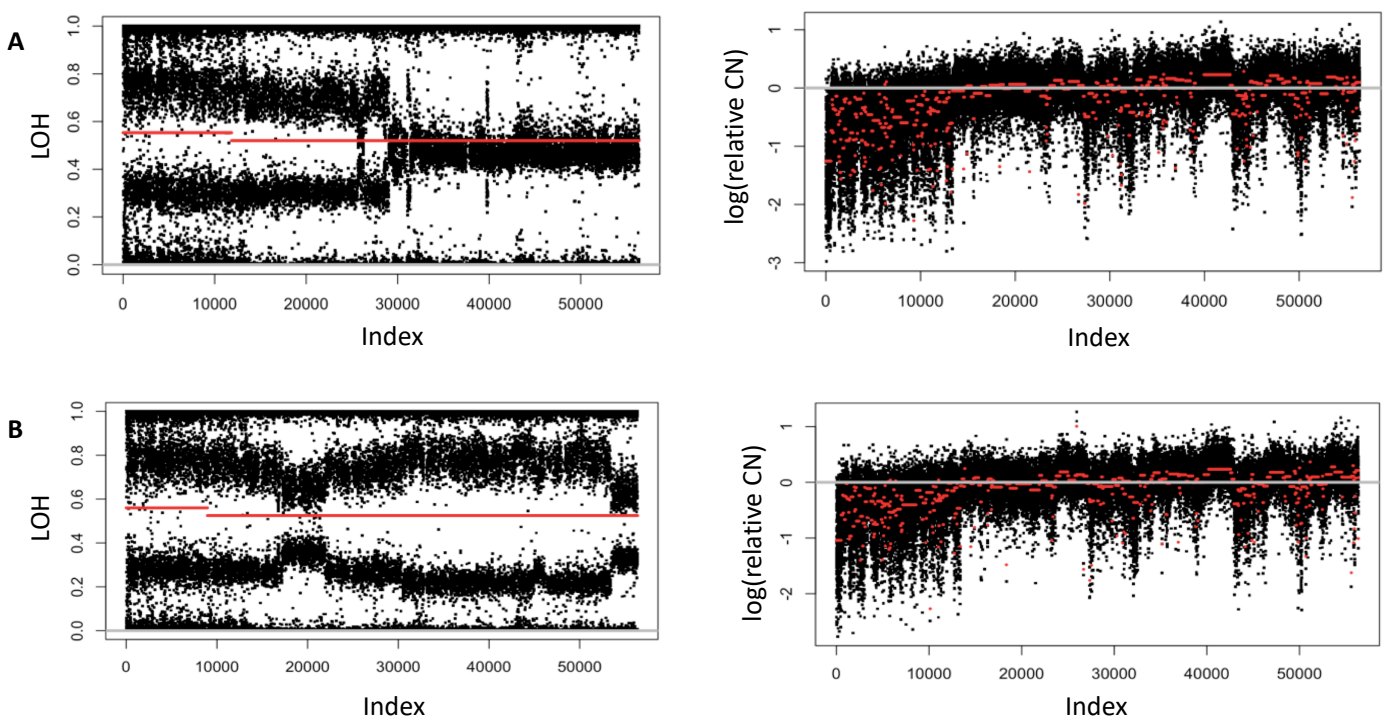

3.13. att. Kopiju skaita variāciju analīze

A - 1. hromosoma ar chromothripsis fenomenu (pacients nr. 14), BPI 365. B - 8. pacienta hromosoma 1 ar chromothripsis fenomenu, BPI 349
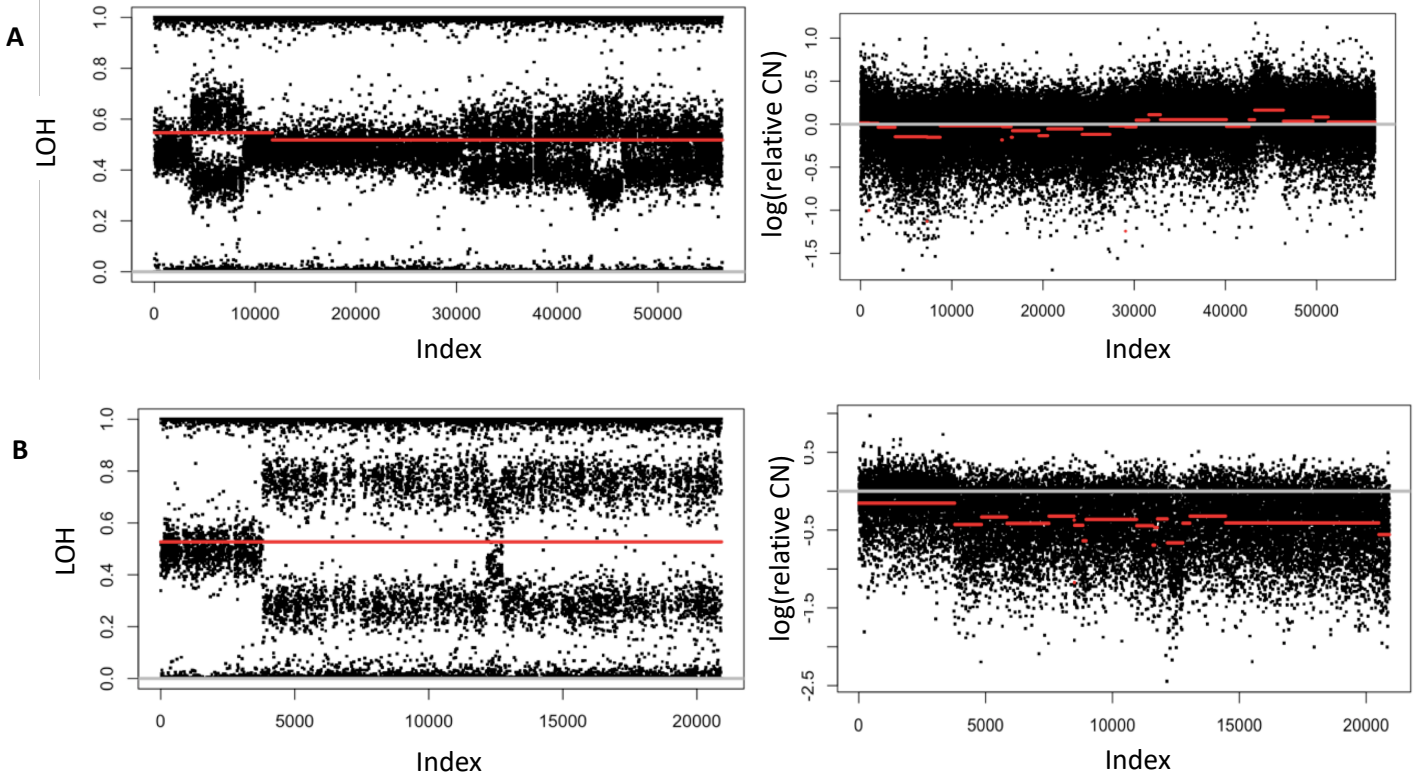

3.14. att. Kopiju skaita variāciju analīze

A - 5. pacients 1. hromosoma, chromothripsis fenomens nav konstatēts, BPI 27. B - 2. pacients, 18 hromosoma, chromothripsis fenomens nav konstatēts, BPI 19

\section{Chromothripsis ietekme uz izdzīvotību}

Kopējā pētāmo pacientu grupā aprēkinātā vidējā bezprogresijas izdzīvotība (mPFS) bija 8 mēneši, 1 gada PFS - 33,3 \%, bet 2 gadu PFS - 5,6 \%. Vidējā kopējā izdzīvotība (mOS) bija 21 mēnesis, 1 gada OS - 78,9\%, 2 gadu OS - 42,1\%, 3 gadu OS 21,1\%.

Pacientiem ar chromothripsis mPFS bija 14 mēn., salīdzinot ar 8 mēn. pacientiem bez chromothripsis (HR 3,43; 95\%KI 1,07-10,99; p = 0,03), (3.15. attēls). Līdzīgi dati novēroti 
pacientiem ar augstu lūzumpunktu nestabilitātes indeksu. Pacientiem ar LPI $\geq 1400$ mPFS bija 14 mēneši, bet pacientiem ar LPI < 1400 mPFS bija 8 mēneši (HR 3,43; p = 0,03) (3.15. attēls).

Pacientiem, kuriem pirms terapijas uzsākšanas KEA nebija paaugstināts $(\leq 5,5 \mathrm{ng} / \mathrm{ml})$, mPFS bija 14 mēneši, bet pacientiem ar sākotnēji paaugstinātu KEA līmeni mPFS bija 8 mēn. (HR 0,29; p = 0,03) (3.16. attēls). Savukārt pacientiem ar metastātisku taisnās zarnas vai sigmveida zarnas vēzi mPFS bija 8 mēneši, salīdzinot ar pacientiem ar metastātisku resnās zarnas vēzi, kuriem mPFS bija 11,5 mēneši (HR 0,33; $95 \%$ KI 0,11-0,97; p = 0,043).
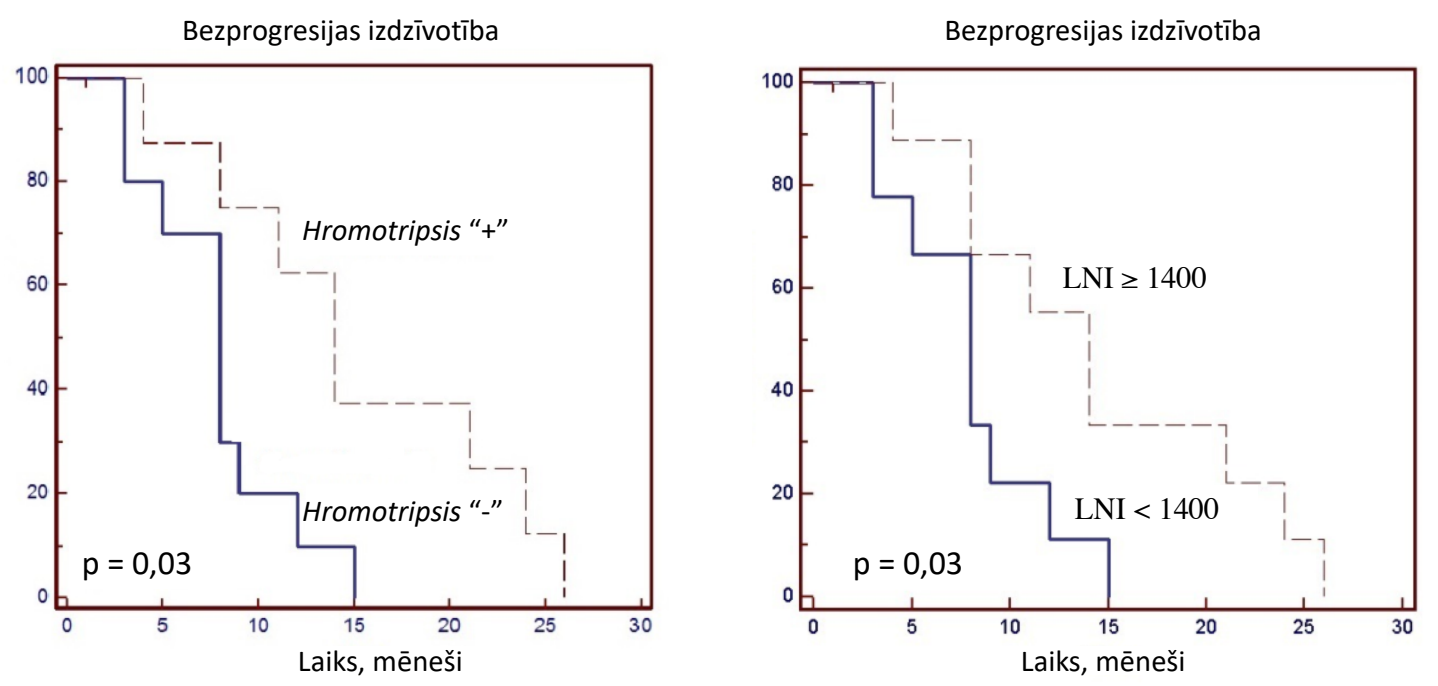

3.15. att. Chromothripsis un LNI ietekme uz bezprogresijas izdzīvotību

mPFS pacientiem bez chromothripsis: 8 mēneši; mPFS pacientiem ar chromothripsis: 14 mēneši; HR 3,43; 95 \%KI 1,07-10,99; $\mathrm{p}=0$ 0,03. mPFS pacientiem ar LNI $\geq 1400$ : 14 mēneši, mPFS pacientiem ar LNI $<1400$ ir 8 mēneši, HR 3,43, p = 0,03. LNI - lūzumpunktu nestabilitātes indekss
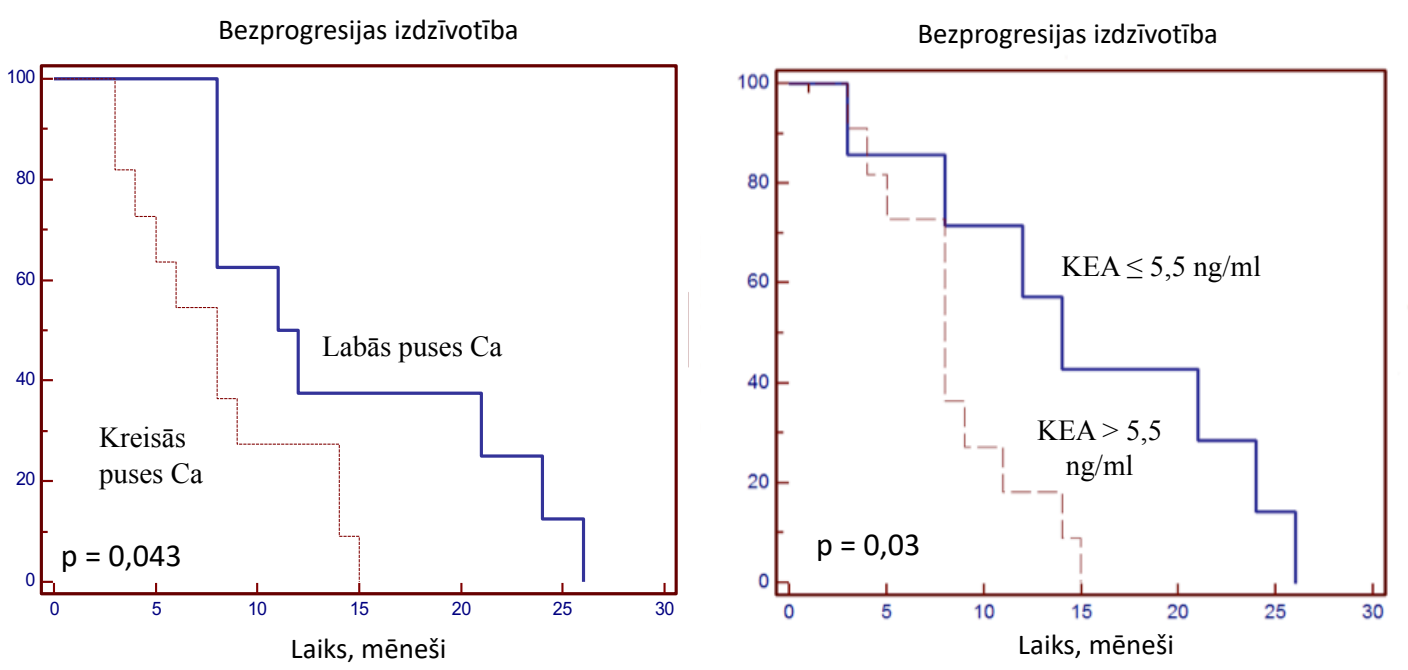

3.16. att. Klīnisko faktoru ietekme uz bezprogresijas izdzīvotību

Vidējā bezrecidīva izdzīvotība (mPFS) pacientiem ar labās puses audzēju (resnā zarna): 11,5 mēneši; mPFS pacientiem ar kreisās puses audzēju: 8 mēneši; HR 0,33, $\mathrm{p}=0,043$. mPFS pacientiem ar paaugstinātu KEA: 8 mēneši; mPFS pacientiem ar KEA $\leq 5,5 \mathrm{ng} / \mathrm{ml}$ : 14 mēneši; HR 0,29, $\mathrm{p}=0,03$. KEA - karcinoembrionālais antigēns, $\mathrm{Ca}-$ karcinoma 
Pacientiem ar chromothripsis mOS bija 33 mēn., salīdzinot ar 19 mēn. pacientiem bez chromothripsis, tomēr šie dati nebija statistiski ticami (HR 1,4004; p = 0,52). Identiski rādītāji bija arī pacientiem ar augstu LNI. Pacientiem, kuriem pirms terapijas uzsākšanas KEA nebija paaugstināts $(\leq 5,5 \mathrm{ng} / \mathrm{ml})$, mOS bija 19,5 mēneši, bet pacientiem ar sākotnēji paaugstinātu KEA līmeni mOS bija 33 mēneši (HR 0,81; p = 0,69).

\subsection{Delēciju analīze pacientiem ar chromothripsis}

10 pacientiem no iepriekšējās pētījuma grupas, tika konstatēts chromothripsis fenomens. Šai apakšgrupai tika veikta kop̄̄go delēciju analīze. Pacientu klīniskie dati norādīti 3.12. tabulā.

Visi desmit pacienti saṇēma FOLFOX tipa pirmās līnijas k̦īmijterapiju. Pēc progresijas 8 pacienti saṇēma irinotekānu saturošu otrās līnijas k,īmijterapiju, 2 pacienti k, neturpināja. Divi pacienti saṇēma trešās līnijas terapiju. Vienam pacientam pēc otrās līnijas k̦īmijterapijas sanemšanas veikta aknu metastāžu rezekcija, vienam -veikta transarteriāla ķīmijembolizācija (TACE), izmantojot ar irinotekānu pildītas mikrosfēras. Pacienti tika novēroti līdz 2016. gada augustam, mPFS šajā pētījuma apakšgrupā bija 14 mēneši (4-26 mēneši).

Pacientu klīnisko rādītāju raksturojums $(\mathbf{n}=10)$

3.13. tabula

\begin{tabular}{|c|c|c|c|c|c|c|c|}
\hline $\begin{array}{c}\text { Pacients, } \\
\#\end{array}$ & $\begin{array}{c}\text { PFS, } \\
\text { mēn }\end{array}$ & Vecums & $\begin{array}{c}\text { Dif. } \\
\text { pakāpe }\end{array}$ & $\begin{array}{c}\text { KEA } \\
\text { ng/ml }\end{array}$ & $\begin{array}{c}\text { Primārā } \\
\text { audzēja } \\
\text { lokalizācija }\end{array}$ & $\begin{array}{c}\text { Metastāžu } \\
\text { lokalizācija }\end{array}$ & KRAS \\
\hline 21 & 4 & 74 & 2 & 343,6 & taisnā zarna & plaušas, aknas & mut \\
\hline 14 & 6 & 74 & 2 & 19,5 & resnā zarna & $\begin{array}{c}\text { aknas, } \\
\text { vēderplēve }\end{array}$ & - \\
\hline 3 & 8 & 38 & 2 & 7,1 & resnā zarna & vēderplēve & $\mathrm{wt}$ \\
\hline 6 & 8 & 68 & 3 & 644,4 & resnā zarna & $\begin{array}{c}\text { aknas, } \\
\text { virsnieres, } \\
\text { retroperitoneālie } \\
1 / \mathrm{m}\end{array}$ & $\mathrm{mut}$ \\
\hline 9 & 11 & 67 & 3 & 959,8 & resnā zarna & aknas & $\mathrm{wt}$ \\
\hline 18 & 14 & 63 & 2 & 10,2 & resnā zarna & aknas & $\mathrm{wt}$ \\
\hline 19 & 14 & 60 & - & 2,4 & taisnā zarna & vēderplēve & $\mathrm{wt}$ \\
\hline 20 & 21 & 70 & 2 & 2,6 & resnā zarna & aknas & $\mathrm{mut}$ \\
\hline 24 & 24 & 52 & 3 & 0,8 & resnā zarna & vēderplēve & $\mathrm{wt}$ \\
\hline 8 & 26 & 65 & 2 & 2,4 & resnā zarna & $\begin{array}{c}\text { vēderplēve, } \\
\text { aknas }\end{array}$ & $\mathrm{mut}$ \\
\hline
\end{tabular}

KEA - karcinoembrionālais antigēns, KRAS - Kirsten Ras onkogēns, mut - mutācija, wt - wild type (neizmainīts), PFS - progression free survival (bezprogresijas izdzīvotība), dif. pakāpe - diferenciācijas pakāpe 
Tika apkopoti katras hromosomas deletētie reǵioni, kas pārklājās vismaz 5 pacientiem un identificēti gēni atbilstoši šiem reǵioniem. Grafiski pirmās hromosomas delēcijas ir atspoguḷotas 3.18. attēlā.

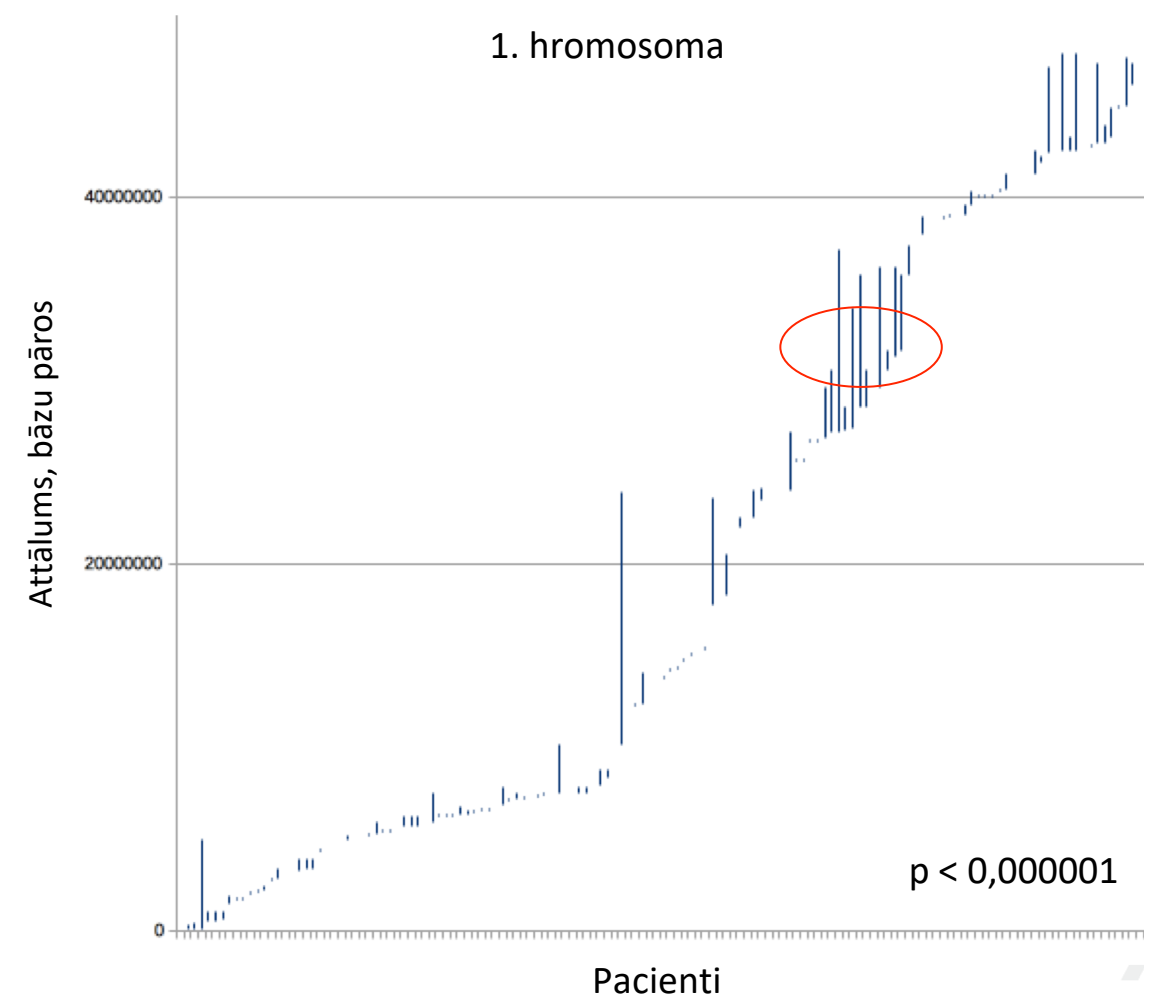

3.17. att. Pirmā hromosoma 10 pacientiem ar chromothripsis, delēciju rajoni, kas pārklājās vairākiem pacientiem

Uz $x$ ass - secīgi sakārtoti 10 pacienti ar chromothripsis. Ar zilajām līnijām apzīmēti katra pacienta delēciju rajoni. Ar sarkano riṇķa līniju apzīmēti delēciju rajoni, kas pārklājās vairākiem pacientiem

Identificētie gēni tika iedalīti piecās grupās: 1) gēni, kas ietekmē proliferāciju vai medikamentu rezistenci, 2) iespējamie audzēja nomācējgēni, 3) prokadherīnu/kadherīnu gēni, 4) gēni, kas ir iesaistīti epiğenētiskajā regulācijā un 5) gēni ar neskaidru lomu onkoǵenēzē. Biežāk konstatētās gēnu delēcijas ir apkopotas 3.14. tabulā. 
Identificētās gēnu delēcijas 10 pacientiem ar chromothripsis

\begin{tabular}{|c|c|c|}
\hline \multicolumn{3}{|c|}{$\begin{array}{l}\text { 1. Gēni, kas ir iesaistīti šūnas proliferācijā, } \\
\text { medikamentu rezistences veidošanās procesā }\end{array}$} \\
\hline Gēns & Apraksts, gēna nozīme & $\begin{array}{l}\text { COSMIC } \\
\text { datubāzes } \\
\text { numurs }\end{array}$ \\
\hline COL11A1 & $\begin{array}{l}\text { COL11A1 ir pārekspresēts recidivējoša nesīkšūnu plaušu vēža } \\
\text { gadījumos. Tas veicina šūnu proliferāciju, migrāciju, invāziju un } \\
\text { medikamentu rezistenci (Shen et al., 2016). }\end{array}$ & $1174 / 41930$ \\
\hline$M A D 2 L 1$ & $\begin{array}{l}\text { Iespējama saistība ar rezistences veidošanos pret k,īmijterapiju } \\
\text { (Lopez-Saavedra et al., 2016). }\end{array}$ & $70 / 32840$ \\
\hline ADAM29 & $\begin{array}{l}\text { ADAM29 ekspresija un gēna patogēnie varianti būtiski ietekmē krūts } \\
\text { un kolorektālā vēža šūnu proliferāciju, migrāciju un invāziju } \\
\text { (Ashktobar et al., 2010). }\end{array}$ & $510 / 33364$ \\
\hline GPM6A & $\begin{array}{l}\text { Potenciāls cilvēka limfoleikozes asociētais onkogēns (Charfi et al., } \\
\text { 2014). }\end{array}$ & $167 / 32746$ \\
\hline EPHA7 & $\begin{array}{l}\text { Samazināta EphA7 mRNS ekspresija konstatēta prostatas vēža šūnās } \\
\text { (Guan et al., 2009). }\end{array}$ & $616 / 34447$ \\
\hline$A D K$ & $\begin{array}{l}\text { ADK ekspresija ir ievērojami augstāka kolorektālā vēža šūnās, } \\
\text { salīdzinot ar audzēja stromas šūnām (Giglioni et al., 2008). }\end{array}$ & $81 / 32840$ \\
\hline NRG3 & $\begin{array}{l}\text { Neiroregulīnu gēnu saimes loceklis, kas kodē tirozīnkināzes } \\
\text { receptoru } E R B B 3 \text { un } E R B B 4 \text { ligandus (epidermālā augšanas faktora } \\
\text { receptoru saimes pārstāvji). }\end{array}$ & $458 / 33190$ \\
\hline \multicolumn{3}{|c|}{ 2. Iespējamie audzēja nomācējgēni } \\
\hline Gēns & Apraksts, gēna nozīme & $\begin{array}{l}\text { COSMIC } \\
\text { datubāzes } \\
\text { numurs }\end{array}$ \\
\hline ROBO2 & $\begin{array}{l}\text { Samazināta } R O B O 2 \text { ekspresija ir konstatēta prostatas vēža audos } \\
\text { (Lopez-Saavedra et al., 2016). }\end{array}$ & $753 / 42092$ \\
\hline$C A D M 2$ & $\begin{array}{l}\text { Gēna metilēšana un samazināta } C A D M 2 \text { audzēja nomācējgēna } \\
\text { ekspresija ir asociēta ar nieru šūnu audzēja progresiju. Pazemināta } \\
C A D M 2 \text { ekspresija saistīta ar augstu hepatocelulāāās karcinomas } \\
\text { recidīva risku pēc radikāli veiktas aknu operācijas (He et al., 2013; } \\
\text { Yang et al., 2014). }\end{array}$ & $297 / 41801$ \\
\hline FAT4 & $\begin{array}{l}\text { FAT4 funkcionē kā kuṇğa, krūts un kolorektālā vēža audzēja } \\
\text { nomācējgēns (Cai et al., 2015; Hou et al., 2016; Yu et al., 2015). }\end{array}$ & $1907 / 33867$ \\
\hline TSG1 & $\begin{array}{l}T S G \text { ekspresija korelē ar kunğa vēža izdzīvotību. TSG1 delēcija } \\
\text { atklāta prostatas vēža šūnās (Lee et al., 2003; Sun et al., 2006). }\end{array}$ & $109 / 32746$ \\
\hline CTNNA3 & $\begin{array}{l}\text { CTNNA3 ir hepatocelulārās karcinomas audzēja nomācējgēns. } \\
\text { Ekspresijas zudums konstatēts daudzu ḷaundabīgu audzēju šūnās (He } \\
\text { et al., 2016; Smith et al., 2006). }\end{array}$ & $504 / 32927$ \\
\hline \multicolumn{3}{|c|}{ 3. Epiǧenētiskie regulatori } \\
\hline Gēns & Apraksts, gēna nozīme & $\begin{array}{l}\text { COSMIC } \\
\text { datubāzes } \\
\text { numurs }\end{array}$ \\
\hline MIR4275 & miR-4275 ir īsa nekodējošā RNS daḷa. Nav zināma funkcija. & \\
\hline MIR1269A & $\begin{array}{l}\text { miR-1269 veicina KRV metastāžu rašanos. miR-1269a ir } \\
\text { paaugstināts vēlīna KRV gadījumā. Veicina hepatocelulārās } \\
\text { karcinomas proliferāciju, nomācot FOXO1 (Yang et al., 2014; Bu et } \\
\text { al., 2015). }\end{array}$ & \\
\hline MIR2054 & miR-2054 ir īsa nekodējošā RNS daḷa. Nav zināma funkcija. & \\
\hline MIR4643 & miR-4643 ir īsa nekodējošā RNS daḷa. Nav zināma funkcija. & \\
\hline MIR4490 & miR-4490 ir īsa nekodējošā RNS daḷa. Nav zināma funkcija. & \\
\hline
\end{tabular}


3.14. tabulas turpinājums

\begin{tabular}{|c|c|c|}
\hline Gēns & Apraksts, gēna nozīme & $\begin{array}{l}\text { COSMIC } \\
\text { datubāzes } \\
\text { numurs }\end{array}$ \\
\hline LINC02549 & Nav zināma funkcija. & \\
\hline PRDM9 & $\begin{array}{l}\text { Gēna kodētais proteīns piedalās mejozē. Palielināta ekspresija ir } \\
\text { konstatēta vairāku veidu malignos audzējos (Houle et al., 2018). }\end{array}$ & $701 / 32967$ \\
\hline \multicolumn{3}{|c|}{ 4. Neskaidras nozīmes gēni } \\
\hline Gēns & Apraksts, gēna nozīme & $\begin{array}{l}\text { COSMIC } \\
\text { datubāzes } \\
\text { numurs }\end{array}$ \\
\hline GABRG1 & $\begin{array}{l}\text { Membrānas proteīns, kas inhibē neirotransmisiju, saistoties ar } \\
\text { benzodiazepīna receptoriem. }\end{array}$ & $403 / 41616$ \\
\hline GABRG2 & $\begin{array}{l}\text { GABA ir CNS šūnu neirotransmiters (receptors). Mutācijas GABRG2 } \\
\text { gēnā novērotas pacientiem ar epilepsiju. }\end{array}$ & $317 / 41865$ \\
\hline COX7B2 & $\begin{array}{l}\text { Citohromoksidāze. Mutācija ir aprakstīta saistībā ar retu pārmantotu } \\
\text { nazofaringeālu vēzi Dienvidkīnas iedzīvotājiem (Liang et al., 2004). }\end{array}$ & $46 / 41646$ \\
\hline TECRL & $\begin{array}{l}\text { Mutācijas TECRL ir aprakstītas pacientiem ar ventrikulāru } \\
\text { tahikardiju. }\end{array}$ & $247 / 41578$ \\
\hline$U G T 2 B 4$ & $\begin{array}{l}\text { UDP glukuronosiltransferāze, enzīms, kas piedalās steroīdo hormonu } \\
\text { un žultsskābju metabolismā. Mutācija ir aprakstīta saistībā ar krūts } \\
\text { vēža risku (Sun et al., 2011). }\end{array}$ & $283 / 32747$ \\
\hline GLRA3 & Gēns kodē glicīna receptoru alfa. Nav zināma saistība ar audzējiem. & $204 / 32748$ \\
\hline FAM174A & $\begin{array}{l}\text { Gēns kodē membrānas proteīnu 157. Nav zināma saistība ar } \\
\text { audzējiem. }\end{array}$ & $47 / 32746$ \\
\hline ST8SIA4 & Neirālo šūnu adhēzijas molekulas (NCAM1) modulators. & $187 / 32812$ \\
\hline PRR16 & $\begin{array}{l}\text { Kodē Largen - zīdītāju šūnu izmēra molekulāro regulētāju. } \\
\text { Largen vieno mRNA translāciju, mitohondriju funkcijas un šūnu } \\
\text { izmēra kontroli (Yamamoto et al., 2014). }\end{array}$ & $163 / 32724$ \\
\hline FTMT & Mitohondriālais ferritīns. Nav zināma saistība ar audzējiem. & $240 / 32746$ \\
\hline KHDRBS2 & $\begin{array}{l}\text { Ar signālu pārvadi asociētais proteīns. Nav zināma saistība ar } \\
\text { audzējiem. }\end{array}$ & $303 / 32878$ \\
\hline EYS & $\begin{array}{l}\text { Kodē proteīnu, kas ir atrodams tīklenes fotoreceptoros. Mutācija ir } \\
\text { konstatēta autosomāli recisīvas retinitis pigmentosa saslimšanas } \\
\text { gadījumā. }\end{array}$ & $424 / 33464$ \\
\hline$M A N E A$ & $\begin{array}{l}\text { Gēns kodē alfa-endomannozidāzi, Goldži kompleksa proteīnu. Nav } \\
\text { zināma saistība ar audzējiem. }\end{array}$ & $123 / 32809$ \\
\hline FUT9 & $\begin{array}{l}\text { Glikoziltransferāžu saimes loceklis - fukoziltransferāze 9. FUT9 } \\
\text { inaktivācija ir aprakstīta resnās zarnas vēža onkoğenēzē (Auslander et } \\
\text { al., 2017) }\end{array}$ & $218 / 32746$ \\
\hline GRIK2 & $\begin{array}{l}\text { Neirotransmiteru receptors smadzeņu šūnās. Mutācija gēnā ir saistīta } \\
\text { ar pārmantotu garīgu atpalicîbu. Nav zināma saistība ar audzējiem. }\end{array}$ & $518 / 33002$ \\
\hline$S S P O$ & $\begin{array}{l}\text { SCO-spondīns, nozīmīgs trofoblasta un placentas fizioloğiskajos } \\
\text { procesos. Nav zināma saistība ar audzējiem. }\end{array}$ & \\
\hline$S G C Z$ & $\begin{array}{l}S G C Z \text { kodē vienu no sarkoglikānu kompleksa proteīniem, kas ir daḷa } \\
\text { no distrofīna-asociētā glikoproteīna kompleksa (DGC), kas, savukārt, } \\
\text { ir iekšējā citoskeleta un ekstracelulārās matrices sastāvdala. }\end{array}$ & $258 / 32747$ \\
\hline CNTN5 & $\begin{array}{l}\text { Neironālās membrānas proteīns, kuram piemīt šūnu adhēzijas } \\
\text { molekulas funkcijas. Nav zināma saistība ar audzējiem. }\end{array}$ & $602 / 33002$ \\
\hline
\end{tabular}


3.14. tabulas turpinājums

\begin{tabular}{|c|c|c|}
\hline \multicolumn{3}{|c|}{ 5.Prokadherīnu/kadherīnu saime } \\
\hline Gēns & Apraksts & COSMIC \\
\hline PCDH10 & $\begin{array}{l}\text { PCDH10 inhibē aizkunğga dziedzera vēža šūnu proliferāciju, invāziju } \\
\text { un migrāciju (Qiu et al., 2016). } \\
\text { PCDH10 epiğenētiska inaktivācija ir nozīmīga kolorektālā vēža } \\
\text { onkoğenēzē, vēža invāzijā un metastazēšanās procesā. Tas tiek } \\
\text { uzskatīts par nozīmīgu audzēja nomācējgēnu (Zhong et al., 2017). } \\
\text { PCDH10 funkcijas zudums veicina aknu metastāžu veidošanos. } \\
\text { PCDH10 delēcija ir nelabvēlīgs KRV prognostisks markieris (Jao et } \\
\text { al., 2014). }\end{array}$ & $763 / 32849$ \\
\hline PCDH18 & $\begin{array}{l}P C D H 18 \text { ir bieži inaktivēts KRV šūnās promotera metilācijas } \\
\text { rezultātā (Zhou et al., 2017). }\end{array}$ & $563 / 32837$ \\
\hline $\mathrm{CDH} 18$ & $\begin{array}{l}\text { CDH18 ir saistīts ar KRV attīstību (Venkatachalam et al., 2011; } \\
\text { Chalmers et al., 1999). Gēna mutācija vai inaktivācija var veicināt } \\
\text { audzēja proliferāciju. }\end{array}$ & $670 / 33085$ \\
\hline $\mathrm{CDH} 12$ & $\begin{array}{l}\text { Kadherīns-12 veicina kolorektālā vēža šūnu proliferāciju un veicina } \\
\text { progresiju. Augsta } C D H 12 \text { ekspresija asociēta ar audzēja invāzijas } \\
\text { dziḷmu un sliktāku prognozi. CDH12 ir jauns kolorektālā vēža } \\
\text { diagnostisks un prognostisks markieris (Ma et al., 2016). }\end{array}$ & $560 / 32970$ \\
\hline $\mathrm{CDH1O}$ & $\begin{array}{l}\text { CDH10 mutācija var inaktivēt šūnu adhēziju. Mutācija aprakstīta } \\
\text { MSI-H kolorektālā vēža un kunǵa vēža gadījumos (An et al., 2015). }\end{array}$ & $799 / 33400$ \\
\hline PCDH15 & $\begin{array}{l}\text { PCDH15 ir kadherīnu saimes loceklis, kas kodē membrānas } \\
\text { proteīnus, kas, savukārt, ir iesaistîti kalcijatkarīgajā starpšūnu } \\
\text { adhēzijā. }\end{array}$ & $1187 / 33222$ \\
\hline
\end{tabular}

COSMIC - Catalogue of Somatic mutations in Cancer (Vēža somatisko mutāciju katalogs)

Vairāk nekā pusei pētāmo pacientu tika konstatētas 8 vēža nomācējgēnu (ROBO2, CADM2, FAT4, PCDH10, PCDH18, CDH18, TSG1, CTNNA3) un 4 onkogēnu (CDH12, GPM6A, ADAM29, COL11A1) delēcijas. $60 \%$ pacientu konstatēta COL11A1 delēcija. Pacientiem ar salīdzinoši garāku PFS tika konstatētas delēcijas miRNS kodējošajos gēnos (MIR1269, MIR4465, MIR1261, MIR4490). Četriem pacientiem ar PFS virs 14 mēnešiem atrasta onkogēna $N R G 3$ delēcija.

3.14. tabulā ir atspoguḷotas biežākās delēcijas, kas pārklājās vismaz 5 pacientiem, un to saistība ar bezprogresijas izdzīvotību. 
Deletētie gēni, kas pārklājās vismaz 5 pacientiem

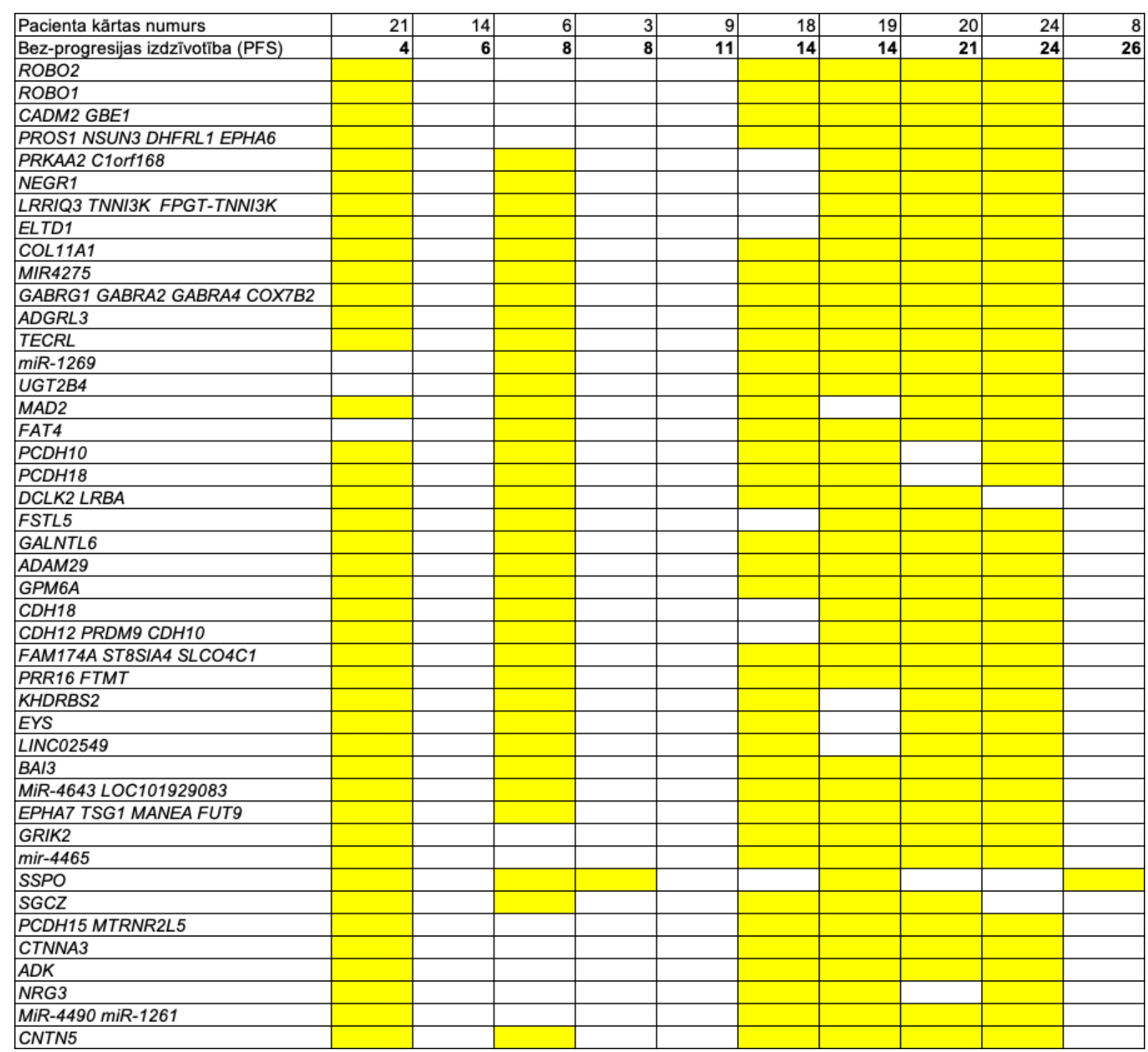

Dzeltenā krāsā - delēcija 


\section{Diskusija}

Promocijas darbs sastāv no trim atsevišk,ām pētījuma dalāam, kuras vieno metastātiska kolorektālā vēža prognostisko un prediktīvo faktoru izpēte. Tika pētīti gan klīniskie parametri (pacientu vecums, ārstēšanas veids, neitrofīlo leikocītu skaita izmaiņas, u.c.), gan molekulāri genētiskie faktori (LPI, chromothripsis) un to ietekme uz bezprogresijas un kopējo izdzīvotību. Pirmā un otrā darba sadaḷa tika veltīta klīnisko prognostisko un prediktīvo faktoru izpētei. mKRV aizvien vēl ir fatāla saslimšana, kuras labākā ārstēšanas stratēg̣ija vēl tiek meklēta, lai pēc iespējas pagarinātu izdzīvotību. Saslimšana ir heterogēna, tās iznākumu un prognozi ietekmē multipli faktori. Attīstoties molekulārajai ǵenētikai un jauniem medikamentiem, aizvien vairāk tiek atklāti jauni prediktīvi un prognostiski markieri.

\subsection{Nerezecējama mKRV analīze P.Stradiṇa KUS Onkoloğijas klīnikā}

Nerezecējama metastātiska kolorektālā vēža pacienta pamatārstēšana ir ilgstoša medikamentoza terapija ar mērki pagarināt bezprogresijas un kopējo izdzīvotību, kontrolēt slimības simptomus, būtiski nepasliktinot dzīves kvalitāti. P.Stradiṇa KUS pacientu analīze tika veikta, lai salīdzinātu izdzīvotības datus ar kopējiem Latvijas datiem par kolorektālo vēzi, kā arī ar pētījumu rezultātiem. Tika apkopoti $220 \mathrm{mKRV}$ pacientu dati. Atlases procesā tika atsijāti pacienti, kuri k,īmijterapiju nesaṇēma vēža izplatības un smaga vispārējā stāvokḷa dēl, un pacienti ar rezecējamu mKRV, jo šo pacientu prognoze ir krasi atškirīga. Tika izslēgti arī tie pacienti, kuru medicīniskajā dokumentācijā nebija informācijas par diagnosticēšanas datumu, objektīvi apstiprinātu progresijas datumu, ārstēšanas veidu.

Kirurğiska ārstēšana ir agrīna un lokāli izplatīta kolorektālā vēža ārstēšanas stūrakmens, bet metastātiska audzēja ārstēšanas pamatmetode ir kombinēta medikamentoza terapija. Vidējā bezprogresijas izdzīvotība (mPFS) pacientiem, kas klīnisko pētījumu ietvaros saṇem pirmās līnijas FOLFOX vai FOLFIRI terapiju, ir 8 mēneši, bet vidējā kopējā izdzīvotība (mOS) 18 mēneši (Colucci et al., 2005; Tournigand et al., 2004). Bevacizumaba vai anti-EGFR antivielu pievienošana oksaliplatīnu saturošai ķīmijterapijai pagarina mPFS līdz 10 mēnešiem, bet mOS līdz 24 mēnešiem (Bokemeyer et al., 2009; Douillard et al., 2010; Tol et al., 2009). Mūsu pētījumā ieklauto pacientu mPFS bija 8 mēneši, bet mOS 17 - mēneši, kas ir līdzīga klīnisko pētījumu datiem. Mērḳterapijas pievienošana būtiski neuzlaboja ne bezprogresijas, ne kopējo izdzīvotību, ko varētu izskaidrot ar mazo apakšgrupas pacientu skaitu.

Biežākais pirmās līnijas kīmijterapijas veids pētījuma pacientiem bija oksaliplatīnu saturoša terapija, kā tiek rekomendēts ESMO vadlīnijās, to saṇēma 82 \% pacientu. N,emot vērā, 
ka bevacizumabs, cetuksimabs un panitumumabs tika iekḷauts Kompensējamo zālu sarakstā tikai 2018. gadā, tikai $11 \%$ mūsu pētījuma pacientu saṇēma mērḳa terapiju, paši sedzot terapijas izmaksas. Irinotekānu saturošu k,īmijterapiju pirmajā līnijā nedaudz biežāk (11,7 \% vs 4 \%) saṇēma pacienti metahrona mKRV apakšgrupā, ko var izskaidrot ar to, ka oksaliplatīnu saturošu terapiju šie pacienti bija saṇēmuši jau iepriekš kā adjuvantu k,īmijterapiju pēc radikālas primārā audzēja (II-III stadijas) ārstēšanas.

Ir publicēti dati par sinhronu vai metahronu metastāžu prognostisko nozīmi. Dažādu pētījumu dati parāda pretrun̄̄gus rezultātus (Tournigand et al., 2004; Colluci et al., 2005). Mekenkamp et al. 2010. gadā publicēja CAIRO pētījuma papildanalīzes datus - tika analizēta 550 pacientu klīnisko parametru ietekme uz izdzīvotību. Netika konstatēta kopējās izdzīvotības atškirība pacientiem ar sinhronām vai metahronām metastāzēm (HR 1,05, p = 0,74) . Mūsu analīzē arī netika konstatēta statistiski nozīmīgas bezprogresijas un kopējās izdzīvotības atškirības starp abām apakšgrupām: mOS 17 mēn vs 17 mēn (HR 1,02, p = 0,9), bet mPFS - 8 mēn. vs 8 mēn. (HR 0,9, p = 0,56). Lai arī Mekenkamp pētījumā pierādīja, ka sinhrona mKRV gadījumā ir tādi nelabvēlīgi prognostiskie faktori kā zema diferenciācijas pakāpe, labās puses audzējs, sliktāks pacienta vispārējais stāvoklis un paaugstināts LDH rādītājs, izdzīvotības rādītāji apakšgrupā nebija sliktāki. Autori to saista ar to, ka metahrona mKRV pacientiem varētu būt raksturīga rezistence pret k̦īmijterapiju, jo ir iepriekš saṇēmuši adjuvantu terapiju, rezultātā izlīdzinot rādītājus abās apakšgrupās.

Vairāk par $80 \%$ pacientu, kas ir saṇēmuši mKRV pirmās līnijas kīmijterapiju, ir piemēroti otrās līnijas k,īmijterapijai, kas būtiski pagarina pacienta dzīvildzi. Mūsu retrospektīvajā analīzē $57 \%$ pacientu saṇēma otrās līnijas k,īmijterapiju. Biežākā terapijas izvēle bija irinotekānu saturoša k̦īmijterapija - 85 \% pacientu. Pacientiem, kas san̄ēma otrās līnijas ḳīmijterapija, mūsu pētījumā tika konstatēts ievērojams statistiski nozīmīgs izdzīvotības ieguvums - mOS 20 mēn. vs 11 mēn. (HR 0,36, p < 0,0001), turklāt pacientiem ar metahronu mKRV, kas san̄ēma FOLFIRI ar bioloğisko medikamentu, mOS bija 38 mēn. (p < 0,0001). mPFS pacientiem, kas saṇēma FOLFIRI otrās līnijas terapijā, bija 5 mēneši; šie dati ir salīdzināmi ar klīnisko pētījumu rezultātiem (4-6 mēn).

Latvijā 2017. gadā pēc SKPC datiem $5 \%$ diagnosticēto kolorektālo pacientu vecums bija < 50 gadiem. Mūsu analīzē 12,7 \% mKRV pacientu bija vecumā līdz 50 gadiem. Lieu et al. 2014. gadā publicēja līdzīgas analīzes datus, kurā iekḷauti 20000 pacienti no 24 pirmās linnijas k,īmijterapijas pētījumiem - $15 \%$ pacientu bija jaunāki par 50 gadiem. Tika konstatēta pacienta vecuma saistība ar bezprogresijas un kopējo izdzīvotību: jauniem pacientiem bija par $19 \%$ paaugstināts letāla iznākuma risks un par $22 \%$ - progresijas risks, salīdzinot ar vidēja vecuma grupu. Mūsu pētījuma dati parāda pretējo - gan mPFS (9 mēn. vs 8 mēn., p = 0,045), 
gan mOS (30 mēn. vs 16 mēn., $\mathrm{p}=0$,0002) ir labāki pacientiem, kas jaunāki par 50 gadiem. Turklāt 5 gadu kopējā izdzīvotība jauno pacientu grupā sasniedz 18,8\%. Šos rezultātus var izskaidrot ar faktu, ka pacientu vispārējais stāvoklis šajā vecumā ir labs, ir retākas blakussaslimšanas, kā arī ir labāka ķīmijterapijas panesamība. Kā arī var pien,emt, ka jauniem pacientiem audzēja bioloğija un ǵenētika atškiras: šajā grupā biežāk sastopami pārmantotā vēža sindromi, bet retāk - "adenoma-karcinoma” onkoğenēzes procesā veidojušies sporādiski zarnas audzēji.

Biežākā mKRV metastāžu lokalizācija ir aknas. Mūsu pētījumā aknu metastāzes (bez citu orgānu distālām metastāzēm) konstatētas $42 \%$ pacientu, šiem pacientiem mPFS bija 8 mēneši un mOS - 17 mēneši. Tikai šīs apakšgrupas 3,4 \% pacientu bija dzīvi pēc 5 gadiem. Vissliktākie izdzīvotības dati bija pacientiem ar multiorgānu metastāzēm - mOS 14,5 mēneši, un tikai $56 \%$ pacientu bija dzīvi 1 gadu pēc diagnozes.

Tika salīdzināti pacienti, kas saṇēma ārstēšanu 2004.- 2011 . gadā un 2012.- 2016. gadā, un rezultātā netika atklāta statistiski ticama izdzīvotības atšķirība. 2012. gadā Acta Chirurgica Latviensis tika publicēts mūsu pētījums par nerezecējama mKRV ārstēšanas rezultātiem laika posmā no 2004. gada līdz 2011. gadam (Skuja et al., 2012). Interesanti, ka metahrona mKRV pacientiem bija labāka mPFS un mOS, bet mūsu kopējā pacientu analīzē, kurā iekḷauti visi pacienti, šī atšķirība vairs netika konstatēta. To var izskaidrot tā, ka pieaugot pētāmo pacientu skaitam, rezultāti kḷūst objektīvāki. Salīdzinot abus laika intervālus, mēs nekonstatējām būtiskas izdzīvotības atšķirības. Kopējā izdzīvotība bija labāka pacientiem, kas sanēema terapiju pēc 2012. gada, bet atškirība nebija statistiski ticama. Šo tendenci mēs saistām ar to, ka pieaug ārstu pieredze mKRV ārstēšanā, daudz biežāk tiek izmantota mFOLFOX6 shēma iepriekšējās FOLFOX4 vietā, tiek pielietotas vairāku līniju terapijas, kā arī notiek rūpīgāka pacientu atlase pirms medikamentozās terapijas uzsākšanas.

Veicot daudzfaktoru analīzi, mēs atklājām, ka šì pētījuma populācijā nozīmīgākie prognostiskie faktori ir ḳīmijterapijas līniju skaits $(>1)$ un vecums $(<50$ gadiem). Ir svarīgi turpināt mKRV pacientu analīzi, jo, palielinot pētāmo pacientu skaitu un iekḷaujot analīzē pacientus, kas sạ̧em mērķterapiju, mēs varam veikt sava ikdienas darba analīzi, izdarīt secinājumus un uzlabot pacientu ārstēšanas rezultātus.

\subsection{Klīnisko prognostisko un prediktīvo faktoru analīze refraktāra mKRV pacientiem, kas saṇem FTD/TPI}

FTD/TPI (trifluridīna/tipiracila) terapeitiskā efektivitāte sākotnēji tika pierādīta II fāzes pētījumā ar 169 pacientiem (Yoshino et al., 2012) un apstiprināta randomizētā, dubultaklā, placebo kontrolētā pētījumā RECOURSE (Mayer et al., 2015). Šajā pētījumā piedalījās 800 
pacienti ar metastātisku kolorektālo vēzi, kuri iepriekš ārstēti ar vismaz divām k,īmijterapijas shēmām. Pacienti saṇēma trifluridīnu/tipiracilu $35 \mathrm{mg} / \mathrm{m}^{2}$ divas reizes dienā saskan̄ā ar shēmu kopā ar labāko atbalstošo aprūpi vai placebo kopā ar atbilstošu aprūpi. Abās ārstēšanas grupās bija līdz̄̄gi demogrāfiskie un sākotnējie slimības raksturlielumi: visiem pacientiem funkcionālais stāvoklis pēc ECOG (Eastern Cooperative Oncology Group) skalas bija 0 vai 1. $K R A S$ statuss, iestājoties pētījumā, bija vai nu pirmatnējā tipa (49\%), vai ar KRAS mutāciju (51\%). Pacienti turpināja terapiju līdz slimības progresijai vai līdz nepien,emamai toksicitātei. Šajā pētījumā ar trifluridīnu/tipiracilu ārstētiem pacientiem kopējā izdzīvotība (mOS) bija statistiski un klīniski nozīmīgi garāka: 7,2 mēneši salīdzinājumā ar 5,2 mēnešiem; riska attiecība (HR) 0,69; p < 0,0001. 1 gada izdzīvotības dati - gandrīz divas reizes labāki: 27,1 \% salīdzinājumā ar 16,6 \%. Bezprogresijas izdzīvotība (mPFS) - nozīmīgi garāka: HR 0,48; $\mathrm{p}<0,001$.

Ar trifluridīnu/tipiracilu ārstētie pacienti sasniedza ilgstošāku slimības kontroli un stabilizāciju: (44\% salīdzinājumā ar $16 \%, \mathrm{p}<0,01$ ), un šie pacienti ilgāk bija apmierinošā vispārējā stāvoklī, kas liecina par labākas dzīves kvalitātes saglabāšanu. Biežākās medikamenta blaknes bija leikopēnija, neitropēnija, anēmija un trombocitopēnija, pārsvarā asimptomātiskas un koriĝ̣ejamas ar standartterapiju. Terapijas pārtraukšanas rādītājs bija zems: 3,6 \% salīdzinājumā ar 1,5\% placebo grupā (Mayer et al., 2015; Yoshino et al., 2012).

Pirmsreǵistrācijas Lonsurf pacientu atbalsta programma norisinājās vienlaicīgi 20 valstīs, kopā iesaistot 2093 pacientus (Salvatore et al., 2016), t.sk. arī Latvijā, iesaistot 14 pacientus ar refraktāru mKRV.

Mūsu novērojuma grupā bija līdzīgi rezultāti kā minētajos klīniskajos pētījumos - mPFS 5 mēneši un mOS 7 mēneši. Turklāt, 3. un 4. pakāpes neitropēnija, kas bija visbiežāk reǵistrētā blakusparādība (28,5 \% pacientu), bija saistīta ar labāku ārstēšanas iznākumu (mPFS 7 mēn, HR 0,24, un pagarināta OS, HR 0,25). Šādi rezultāti tika ziṇoti arī iepriekšējos pētījumos pacientiem ar refraktāru mKRV. Hamauchi et al. 2017. gadā publicēja retrospektīva pētījuma rezultātus, kas pierādīja neitropēnijas saistību ar ārstēšanas iznākumu. 21 \% pacientu konstatēta 3. un 4. pakāpes neitropēnija pirmajā k̦īmijterapijas kursā. Šajā pacientu apakšgrupā bija labāka gan bezprogresijas izdzīvotība ( 2 mēn. vs 4,3 mēn, HR 0,41,p = 0,002), gan kopējā izdzīvotība (5,7 mēn. vs 8,0 mēn., HR 0,59, $\mathrm{p}=0,084)$.

Neraugoties uz iekḷauto pacientu mazo skaitu, tika novērots, ka laiks no pirmās kīmijterapijas līnijas uzsākšanas līdz FTD/TPI uzsākšanai var tikt izmantots kā prognostisks faktors: mPFS pacientiem ar laika intervālu > 18 mēnešiem bija 7 mēn. (HR 0,15), bet vēža specifiskās mirstības riska attiecība bija 0,23. Līdzīgi rezultāti tika ziṇoti arī Hamauchi 2017. gada publikācijā - pacientiem ar iepriekš saņemtās terapijas intervālu > 18 mēnešiem 
novērota labāka mPFS (HR 0,47, p =0,01) un mOS (HR 0,44, p =0,01). Bet Moriwaki 2019. gada publikācijā pacientiem ar laika intervālu > 18 mēnešiem no pirmās līnijas terapijas uzsākšanas bija labāka kopējā izdzīvotība (HR 1,42, p =0,043). Analizējot šos rezultātus, var pieṇemt, ka pacientiem ar īsāku iepriekšējās ārstēšanas ilgumu un ātrāku progresiju pēc saṇemtās k̦īmijterapijas ir mazāks ieguvums no FTD/TPI terapijas. Šis pieņēmums rada hipotēzi, ka agresīvu un k,īmijterapijas rezistentu audzēju šūnās, iespējams, ir mutācijas vai genoma izmainas, kas izraisa rezistenci pret FTD/TPI.

Šajā pētījuma sadaḷā arī tika konstatēti trūkumi - pētāmā grupa bija maza, tādēl, lai šos rezultātus apstiprinātu un lietotu ikdienas praksē klīnikā, būtu nepieciešams lielāks pacientu skaits. No 2019. gada sākuma medikaments ir iekḷauts Kompensējamo zāḷu sarakstā refraktāra mKRV ārstēšanai. Pacientus varam turpināt uzskaitīt un analizēt, lai nākotnē mēs varētu precīzāk atlasīt daudzārstētos pacientus ar refraktāru mKRV turpmākai k, k̄mijterapijai, nepārārstējot tos, kuriem šĩ ārstēšana varētu būt mazefektīva.

\subsection{Chromothripsis kā metastātiska kolorektālā vēža prediktīvais faktors}

Uzsākot šo pētījumu, tika apkopoti klīniskie dati un savākts materiāls (audu bloki, asins paraugi KEA analīzei) no $45 \mathrm{mKRV}$ pacientiem, kas bija piekrituši dalībai pētījumā. Turpmākajā vēža audu analīzē tika izmantoti tikai 19 pacientu dati, jo pārējiem pacientiem nebija analizējams materiāls - audzēja šūnu saturs paraugā bija < 80 \% vai arī nebija iespējams izdalīt kvalitatīvu materiālu no audu bloka tālākai analīzei. Audu paraugos, kuros vēža saturs ir mazāks par $80 \%$, rezultāts var būt mazinformatīvs, jo to ietekmē audzēja stromas un pacienta neizmainītās šūnas.

Hromosomālo izmaiņu un gēnu mutāciju ietekme uz patoǵenēzi, prognozi un rezistenci pret medikamentozo terapiju ir plaši aprakstīta mKRV pētījumos, tomēr joprojām nav definēta chromothripsis un lūzumpunktu nestabilitātes indeksa (LNI) prognostiskā un prediktīvā vērtība.

Šajā pētījumā tika novērota pozitīva korelācija starp masīvu DNS fragmentāciju un PFS. Pretēji publicētajiem pētījumu datiem, kas liecina par chromothripsis saistību ar sliktu prognozi dažādu ļaundabīgu audzēju pacientiem, mēs konstatējām, ka chromothripsis ir pozitīvs prediktīvs faktors mKRV pacientiem, kas saņem FOLFOX tipa pirmās līnijas ķīmijterapiju. Šo atradi varētu pamatot ar faktu, ka vēža šūnas, kuras ir tikušas pakḷautas tik radikālām DNS izmaiņām kā chromothripsis, ir jūtīgākas uz citotoksisko terapiju ar oksaliplatīnu un 5-FU. Otrs hipotētiskais pieņēmums - audzējam ar augstu lūzumpunktu nestabilitātes indeksu varētu būt raksturīga genomiska nestabilitāte, kurai, savukārt, ir raksturīga labvēlīga prognoze. Šo pien̦ēmumu min arī Luijten et al. (2018), atsaucoties uz mūsu publikāciju savā apkopojošajā 
dažādu lokalizāciju audzēju analīzē, kurā iekļauti tikai divi kolorektālā vēža pētījumi. Mūsu publikācijas datus piemin arī van Poppelen et al. (2018) uveālās melanomas pētījuma publikācijā. Autori piemin varbūtību, ka audzējs ar chromothripsis ir biežāk metastātisks un tiek diagnosticēts vēlīni, kas izskaidro publikāciju datus par šīs genomiskās izmaiņas saistību ar sliktu prognozi, kā arī pieņem to, ka metastāzes ar chromothripsis varētu labāk reaǵēt uz medikamentozo terapiju.

Przybytkowski et al. (2014) savā pētījumā aprakstīja krūts vēža LPI: krūts vēža audos tika konstatēts LPI 25-300, vislielākais DNS pārrāvumu skaits konstatēts 17. hromosomā, bet vismazākais - 4. hromosomā. LPI atšķīrās dažādos krūts vēža molekulārajos tipos; visaugstākais LPI un visbiežāk chromothripsis fenomens tika konstatēts trīskārši negatīvā vēža audos. Šajā pētījumā ar mKRV audiem, augstākais LPI konstatēts 1. un 2. hromosomā, bet zemākais - 21. hromosomā, kā arī lūzumpunktu skaits bija ievērojami lielāks (368 - 4009). Turklāt 10 paraugos $(52,6 \%)$ konstatēts chromothripsis fenomens $\geq 3$ hromosomās, kas ir biežāk, nekā publicēts iepriekš. Augsto LPI un chromothripsis izplatību mūsu pētījuma grupā var izskaidrot ar faktu, ka visiem pētījumā iesaistītajiem pacientiem bija metastātiska saslimšana, kas ir visagresīvākā vēža forma, turpretī Przybytkowski pētījumā tika iekḷautas visu krūts vēža stadiju un molekulāro apakštipu pacientes. Šogad Nature Genetics tika publicēti plašas analīzes rezultāti, kas aptvēra 2658 pacientu vēža paraugus, analizēti 38 dažādu audzēju veidi (Cortés-Ciriano et al., 2020). Tika konstatēts, ka kopējais chromothripsis biežums visos paraugos ir ap $40 \%$, kas ir augstāks rādītājs nekā aprakstīts līdz šim. 32,7 \% kolorektālā vēža paraugu tika konstatēts chromothripsis (17 no 52 paraugiem), kas, savukārt, ir mazāk nekā mūsu pētījumā.

Mūsu pētījumā tika pierādīta chromothripsis saistība ar garāku laiku līdz pirmajai progresijai pēc k,īmijterapijas saņemšanas, bet netika novērota kopējās dzīvildzes pagarināšanās. Kopējo dz̄ivildzi ietekmē daudzi faktori - gan pacienta vispārējais stāvoklis, blakusslimības un vecums, gan pielietotās k̦īmijterapijas veids un secība, gan paša audzēja molekulāri ğenētiskās īpašības.

Vairāk nekā pusei chromothripsis audu paraugu konstatētas astoṇu audzēja nomācējgēnu (ROBO2, CADM2, FAT4, PCDH10, PCDH18, CDH18, TSG1, CTNNA3) un četru onkogēnu (CDH12, GPM6A, ADAM29, COL11A1) delēcijas. Onkogēna COL11A1 delēcija bija sastopama 60 \% vēža paraugu. Literatūrā ir aprakstīts, ka š̄ gēna pārekspresija ir saistīta ar šūnu proliferāciju, migrāciju un platīna rezistenci plaušu vēža pacientiem (Shen et al., 2016). Var izteikt pien̄ēmumu, ka COL11Al delēcija pacientiem ar labākiem bezprogresijas izdzīvotības rādītājiem varētu būt saistīta ar lēnāku šūnu migrāciju, līdz ar to - lēnāku slimības progresiju. Līdzīgs novērojums publicēts par onkogēna MAD2L1 pārekspresiju sēklinieku 
germinālo šūnu vēža pacientiem ar platīna rezistenci (Lopez-Saavedra et al., 2016). Mūsu analīzē pusei audu paraugu konstatēta $M A D 2 L 1$ delēcija, kas savukārt varētu mazināt šūnu proliferāciju un palēnināt slimības progresiju.

$50 \%$ audu paraugu konstatētas MIR1269A un citu mRNS kodējošo gēnu delēcija. Pētījums parāda, ka MIR1269A pārekspresija veicina hepatocelulārās karcinomas proliferāciju un metastāžu formēšanos (Yang et al., 2014). Mūsu pētījumā konstatētās MIR delēcijas pacientiem ar pagarinātu PFS. Samazinātā signālmolekulu ekspresija var būt saistīta ar samazinātu proliferāciju un metastāžu formēšanās potenciālu pacientiem ar mKRV, tādējādi palēninot slimības progresijas ātrumu.

Četriem pacientiem konstatēta $N R G 3$ delēcija, kas, iespējams, samazina vēža šūnu proliferāciju, samazinot EGFR aktivāciju. Gēns kodē EGFR ligandu, kas piesaistoties receptoram, aktivizē intracelulārās signālu pārvades kaskādi un veicina šūnas proliferāciju, migrāciju un diferenciāciju. Delēcijas rezultātā liganda darb̄̄ba tiek apturēta. Lai arī visbiežāk publikācijās šī gēna alterācijas ir pieminētas saistībā ar psihoneiroloğiskām saslimšanām (Kao et al., 2010; Sonuga-Barke et al., 2000), tikai viena bāzu pāra izmaiņas šī gēna robežās spēj ietekmēt bezprogresijas izdzīvotību olnīcu vēža pacientēm, kas saṇem karboplatīnu (Huang et al., 2011).

Promocijas darbā pacientiem ar chromothripsis fenomenu tika apstiprināta garāka bezprogresijas izdzīvotība (14 vs 8 mēneši, $\mathrm{p}=0,03$ ), līdz ar to šo genomisko alterāciju var izmantot kā prediktīvo markieri oksaliplatīna terapijas efektivitātes prognozēšanā.

Divi pacienti šajā pētījuma grupā bija atškirīgi. Pacientam \#21 konstatētas multiplas delēcijas, bet bija visīsākais laiks līdz progresijai. Minētajam pacientam vēža diagnosticēšanas brīdī bija masīvas plaušu un aknu metastāzes, FOLFOX tipa terapija tika agrīni pārtraukta toksicitātes un straujas vispārējā stāvokḷa pasliktināšanās dēl, sekojoši pēc 4 mēnešiem radioloğiski tika apstiprināta slimības progresija. Otram pacientam \#8 bija visgarākais laiks līdz slimības progresijai (26 mēneši), bet tikai viena delēcija, kas pārklājās ar pārējiem pacientiem - SSPO, gēns ar nezināmu funkciju. Tik garu periodu līdz progresijai varētu izskaidrot ar to, ka pacientam sākotnēji veikta radikāla primārā audzēja un aknu un vēderplēves metastāžu rezekcija. Ir zināms, ka ārstē̌̌anas stratēg̣ija - kirurğiskās operācijas apjoms, medikamentozās terapijas intensitāte un veids, kā arī pacienta vispārējais stāvoklis, blakus slimības, metastāžu plašums, būtiski ietekmē gan laiku līdz progresijai, gan kopējo dzīves ilgumu. Zinot to, jaunie molekulārie prognostiskie un prediktīvie faktori ir jāanalizē, n,emot vērā klīnisko ainu. 


\section{Secinājumi}

1. Būtiskākie faktori, kas statistiski ticami uzlabo izdzīvotību, ir pacienta vecums $<50$ gadi, ķīmijterapijas līniju skaits (vairāk par vienu terapijas līniju) un otrās līnijas terapijas veids, bet izdzīvotību pasliktina multiplas metastāzes.

2. Klīniskie rādītāji - 3. un 4. pakāpes neitropēnija un laiks līdz terapijas uzsākšanai (vairāk par 18 mēnešiem) - uzlabo izdzīvotību (PFS un OS) refraktāra metstātiska kolorektālā vēža pacientiem, kuri saņem trešās līnijas terapiju ar FTD/TPI.

3. Chromothripsis un augsts lūzumpunku indekss uzlabo PFS pacientiem ar mKRV, kas saņem pirmās līnijas ķīmijterapiju ar FOLFOX, bet neietekmē OS.

4. Biežākās delēcijas pacientiem ar chromothripsis ir - audzēja nomācējgēnu ROBO2, CADM2, FAT4, PCDH10, PCDH18, CDH18, TSG1, CTNNA3 delēcijas un onkogēnu CDH12, GPM6A, ADAM29, COL11A1, NRG delēcijas. 


\section{Praktiskās rekomendācijas}

1. Pacientiem ar nerezecējamu metastātisku kolorektālo vēzi vairāku līniju paliatīvā ķīmijterapija ir standarta ārstēšanas veids, kas uzlabo bezprogresijas un kopējo izdzīvotību.

2. Refraktāra mKRV pacientiem, kuriem tiek plānota 3. līnijas ārstēšana ar FTD/TPI, ir jāņem vērā iepriekšējās terapijas ilgums, lai prognozētu terapijas efektivitāti. 3.-4. pakāpes neitropēnijas attīstīšanās ir pozitīvs prognostisks un prediktīvs marķieris pacientiem, kas saņem šo terapiju.

3. Chromothripsis un augsts lūzumpunktu skaits ir potenciāli prediktīvi marķieri mKRV pacientiem, kas saņem pirmās līnijas ķ̄īmijterapiju ar FOLFOX. Ir jāturpina pētījumi ar lielāku pacientu grupu, lai apstiprinātu ǵenētisko marķieru klīnisko nozīmi. 


\section{Izmantotā literatūra}

1. Adam, R., Avisar, E., Ariche, A., Giachetti, S., Azoulay, D., Castaing, D., Kunstlinger, F., Levi, F., Bismuth, F. 2001. Five-year survival following hepatic resection after neoadjuvant therapy for unresectable colorectal liver metastases. Annals of Surgical Oncology, 8(4):347-353.

2. Adam, R., Wicherts, D.A., de Haas, R.J., Aloia, T., Lévi, F., Paule, B., Guettier, C., Kunstlinger, F., Delvart, V., Azoulay, D. and Castaing, D. 2008. Complete pathologic response after preoperative chemotherapy for colorectal liver metastases: Myth or reality? Journal of Clinical Oncology, 26(10):1635-1641.

3. Ai, J., Gong, Y., Gregg, J.L., Guan, R., Qiu, W., Xin, D., Gingrich, J.R., Guo, Y., Chang, G. 2013. Aberrant methylation and loss of CADM2 tumor suppressor expression is associated with human renal cell carcinoma tumor progression. Biochemical and Biophysical Research Communications, 435(4):526-532.

4. Allegra, C.J, Yothers, G., O'Connell, M.J., Sharif, S., Petrelli, N.J., Colangelo, L.H., Atkins, J.N., Seay, T.E., Fehrenbacher, L., Goldberg, R.M., O'Reilly, S., Chu, L., Azar, C.A., Lopa, S. and Wolmark, N. 2011. Phase III Trial Assessing Bevacizumab in Stages II and III Carcinoma of the Colon: Results of NSABP Protocol C-08. Journal of Clinical Oncology, 29(1):11-16.

5. Allegra, C.J., Jessup, J.M., Somerfield, M.R., Hamilton, S.R., Hammond, E.H., Hayes, D.F., McAllister, P.K., Morton, R.F., Schilsky, R.L. 2009. American Society of Clinical Oncology provisional clinical opinion: testing for KRAS gene mutations in patients with metastatic colorectal carcinoma to predict response to anti-epidermal growth factor receptor monoclonal antibody therapy. Journal of Clinical Oncology, 27: 2091-2096.

6. Altendorf-Hofmann, A., Scheele, J. 2003. A critical review of the major indicators of prognosis after resection of hepatic metastases from colorectal carcinoma. Surgical Oncology Clinics of North America, 12(1):165-192.

7. Amado, R.G., Wolf, M., Peeters, M., Van Cutsem, E., Siena, S., Freeman, D.J., Juan, T., Sikorski, R., Suggs, S., Radinsky, R., Patterson, S.D., Chang, D.D. 2008. Wild-type KRAS is required for panitumumab efficacy in patients with metastatic colorectal cancer. Journal of Clinical Oncology, 26(10):1626-1634.

8. An, C.H., Je, E.M., Yoo, N.J., Lee, J. 2015. Frameshift mutations of cadherin genes DCHS2, $\mathrm{CDH} 10$ and $\mathrm{CDH} 24$ genes in gastric and colorectal cancers with high microsatellite instability. Pathology Oncology Research, 21(1):181-185.

9. Arnold, D., Lueza, B., Douillard, J.Y., Peeters, M., Lenz, H.J., Venook, A., Heinemann, V., Van Cutsem, E., Pignon, J.P., Tabernero, J., Cervantes, A., Ciardiello, F. 2017. Prognostic and predictive value of primary tumour side in patients with RAS wild-type metastatic colorectal cancer treated with chemotherapy and EGFR directed antibodies in six randomized trials. Annals of Oncology, 28(8):1713-1729.

10. Ashktorab, H., Schäffer, A.A., Daremipouran, M., Smoot, D.T., Lee, E., Brim, H. 2010. Distinct genetic alterations in colorectal cancer. PLoS One, 5(1):e8879.

11. Assumpcao, L., Choti, M.A., Gleisner, A.L., Schulick, R.D., Swartz, M., Herman, J., Gearhart, S.L., Pawlik, T.M. 2008. Patterns of Recurrence Following Liver Resection for Colorectal Metastases Effect of Primary Rectal Tumor Site Archives of Surgery, 143(8):743-749.

12. Auer, R.C., White, R.R., Kemeny, N.E., Schwartz L.H., Shia, J., Blumgart, L.H., Dematteo, R.P., Fong, Y., Jarnagin, W.R. and D'Angelica, M.I. 2010. Predictors of a true complete response among disappearing liver metastases from colorectal cancer after chemotherapy. Cancer, 116(6):1502-1509. 
13. Auslander, N., Cunningham, C.E., Toosi, B.M., McEwen, E.J., Yizhak, K., Vizeacoumar, F.S., Parameswaran, S., Gonen, N., Freywald, T., Bhanumathy, K.K., Freywald, A., Vizeacoumar, F.J., Ruppin, E. 2017. An integrated computational and experimental study uncovers FUT9 as a metabolic driver of colorectal cancer. Molecular Systems Biology, 13(12):956.

14. Baker, A.M., Graham, T.A., Elia, G., Wright, N.A., Rodriguez-Justo, M. 2015. Characterization of LGR5 stem cells in colorectal adenomas and carcinomas. Scientific Reports, 5:8654.

15. Barault, L., Veyrie, N., Jooste, V., Lecorre, D., Chapusot, C., Ferraz, J.M., Lièvre, A., Cortet, M., Bouvier, A.M., Rat, P., Roignot, P., Faivre, J., Laurent-Puig, P., Piard, F. 2008. Mutations in the RAS-MAPK, PI(3)K (phosphatidylinositol-3-OH kinase) signalling network correlate with poor survival in a population-based series of colon cancers. International Journal of Cancer, 122: 2255-2259.

16. Barker, N., Ridgway, R.A., van Es, J.H., van de Wetering, M., Begthel, H., van den Born, M., Danenberg, E., Clarke, A.R., Sansom, O.J., Clevers, H. 2009. Crypt stem cells as the cells-oforigin of intestinal cancer. Nature, 457(7229): 608-611.

17. Bass, A.J., Lawrence, M.S., Brace, L.E., Ramos, A.H., Drier, Y., Cibulskis, K., Sougnez, C., Voet, D., Saksena, G., Sivachenko, A., Jing, R., Parkin, M., Pugh, T., Verhaak, R.G., Stransky, N., Boutin, A.T., Barretina, J., Solit, D.B., Vakiani, E., Shao, W., Mishina, Y., Warmuth, M., Jimenez, J., Chiang, D.Y., Signoretti, S., Kaelin, W.G., Spardy, N., Hahn, W.C., Hoshida, Y., Ogino, S., DePinho, R.A., Chin, L., Garraway, L.A., Fuchs, C.S., Baselga, J., Tabernero, J., Gabriel, S., Lander, E.S., Getz, G., Meyerson, M. 2011. Genomic sequencing of colorectal adenocarcinomas identifies a recurrent VTI1A-TCF7L2 fusion. Nature Genetics, 43(10):964968.

18. Bennouna, J., Sastre, J., Arnold, D., Österlund, P., Greil, R., Van Cutsem, E., von Moos, R., Viéitez, J.M., Bouché, O., Borg, C., Steffens, C.C., Alonso-Orduña, V., Schlichting, C., Reyes-Rivera, I., Bendahmane, B., André, T., Kubicka, S. 2013. Continuation of bevacizumab after first progression in metastatic colorectal cancer (ML18147): a randomised phase 3 trial. Lancet Oncology, 14(1):29-37.

19. Benoist, S., Pautrat, K., Mitry, E., Rougier, P., Penna, C., Nordlinger, B. 2005. Treatment strategy for patients with colorectal cancer and synchronous irresectable liver metastases. British Journal of Surgery, 92:1155-1160.

20. Berlin, J., Van Cutsem, E., Peeters, M., Hecht, J.R., Ruiz, R., Wolf, M., Amado, R.G. and Meropol, N.J. 2007. Predictive value of skin toxicity severity for response to panitumumab in patients with metastatic colorectal cancer (mCRC): A pooled analysis of five clinical trials. Journal of Clinical Oncology, 25(18): suppl 4134.

21. Bertotti, A., Papp, E., Jones, S., Adleff, V., Anagnostou, V., Lupo, B., Sausen, M., Phallen, J., Hruban, C.A., Tokheim, C., Niknafs, N., Nesselbush, M., Lytle, K., Sassi, F., Cottino, F., Migliardi, G., Zanella, E.R., Ribero, D., Russolillo, N., Mellano, A., Muratore, A., Paraluppi, G., Salizzoni, M., Marsoni, S., Kragh, M., Lantto, J., Cassingena, A., Li, Q.K., Karchin, R., Scharpf, R., Sartore-Bianchi, A., Siena, S., Diaz, L.A., Trusolino, L., Velculescu, V.E. 2015. The genomic landscape of response to EGFR blockade in colorectal cancer. Nature, 526(7572):263-267.

22. Bērziṇa, D., Irmejs, A., Kalniete, D., Borošenko, V., Nakazawa-Miklaševiča, M., Rībenieks, K., Trofimovičs, G., Gardovskis, J., Miklaševičs, E. 2012. Novel germline MLH1 and MSH2 mutations in Latvian Lynch syndrome families. Experimental Oncology, 34(1):49-52.

23. Bidard, F.C., Tournigand, C., André, T., Mabro, M., Figer, A., Cervantes, A. 2009. Efficacy of FOLFIRI-3 (irinotecan D1,D3 combined with LV5-FU) or other irinotecan based regimens in oxaliplatin-pretreated metastatic colorectal cancer in the GERCOR OPTIMOX1 study. Annals of Oncology, 20:1042-1047.

24. Bipat, S., van Leeuwen, M.S., Comans, E.F. 2005. Colorectal liver metastases: CT, MR imaging, and PET for diagnosis-metaanalysis. Radiology, 237:123-131. 
25. Blazer 3rd, D.G., Kishi, Y., Maru, D.M., Kopetz, S., Chun, Y.S., Overman, M.J., Fogelman, D., Eng, C., Chang, D.Z., Wang, H., Zorzi, D., Ribero, D., Ellis, L.M., Glover, K.Y., Wolff, R.A., Curley, S.A., Abdalla, E.K. and Vauthey, J.N. 2008. Pathologic response to preoperative chemotherapy: a new outcome end point after resection of hepatic colorectal metastases. Journal of Clinical Oncology, 25(33):5344-5351.

26. Bokemeyer, C., Bondarenko, I., Hartmann, J.T., De Braud, F.G., Schuch, G., Zubel, A., Celik, I., Koralewski, P. 2010. Biomarkers predictive for outcome in patients with metastatic colorectal cancer (mCRC) treated with first-line FOLFOX4 plus or minus cetuximab: Updated data from the OPUS study. 2010 Gastrointestinal Cancers Symposium Abstract No:428.

27. Bokemeyer, C., Bondarenko, I., Makhson, A., Hartmann, J.T., Aparicio, J., de Braud, F., Donea, S., Ludwig, H., Schuch, G., Stroh, C., Loos, A.H., Zubel, A., Koralewski, P. 2009. Fluorouracil, leucovorin, and oxaliplatin with and without cetuximab in the first-line treatment of metastatic colorectal cancer. Journal of Clinical Oncology, 27(5): 663-671.

28. Bokemeyer, C., Kohne, C.H., Ciardiello, F., Lenz, H.J., Heinemann, V., Klinkhardt, U., Beier, F., Duecker, K., Tejpar, S. 2014. Treatment outcome according to tumor RAS mutation status in OPUS study patients with metastatic colorectal cancer (mCRC) randomized to FOLFOX4 with/without cetuximab. Journal of Clinical Oncology, 32 (5s):Abstract 3505.

29. Bu, P., Wang, L., Chen, K.Y., Rakhilin, N., Sun, J., Closa, A., Tung, K.L., King, S., Varanko, A., Xu, Y., Chen, J., Zessin, A.S., Shealy, J., Cummings, B., Hsu, D., Lipkin, S.M., Moreno, V., Gümüş, Z.H., Shen, X. 2015. miR-1269 promotes metastasis and forms a positive feedback loop with TGF- $\beta$. Nature Communication, 6:6879.

30. Cai, H. 2018. ChromothripsisDB: A Curated Database for the Documentation, Visualization, and Mining of Chromothripsis Data. In: Pellestor, F., ed. Chromothripsis. Methods in Molecular Biology, vol 1769, Humana Press, New York, NY: 279-289 http://cgma.scu.edu.cn/ChromothripsisDB/

31. Cai, J., Feng, D., Hu, L., Chen, H., Yang, G., Cai, Q., Gao, C., Wei, D. 2015. FAT4 functions as a tumour suppressor in gastric cancer by modulating Wnt/ $\beta$-catenin signalling. British Journal of Cancer, 113(12):1720-1729.

32. Cancer Genome Atlas Network. 2012. Comprehensive molecular characterization of human colon and rectal cancer. Nature, 487(7407):330-337.

33. Cancer statistics in 2018. https://gco.iarc.fr/today/data/factsheets/populations/428-latvia-fact-sheets.pdf

34. Cannistra, S.A., Matulonis, U.A., Penson, R.T., Hambleton, J., Dupont, J., Mackey, H., Douglas, J., Burger, R.A., Armstrong, D., Wenham, R., McGuire, W. 2007. Phase II study of bevacizumab in patients with platinum-resistant ovarian cancer or peritoneal serous cancer. Journal of Clinical Oncology, 25(33):5180-5186.

35. Cappuzzo, F., Finocchiaro, G., Rossi, E., Jänne, P.A., Carnaghi, C., Calandri, C., Bencardino, K., Ligorio, C., Ciardiello, F., Pressiani, T., Destro, A., Roncalli, M., Crino, L., Franklin, W.A., Santoro, A. and Varella-Garcia, M. 2008. EGFR FISH assay predicts for response to cetuximab in chemotherapy refractory colorectal cancer patients. Annals of Oncology, 19: 717-723.

36. Cassidy, J., Clarke, S., Díaz-Rubio, E., Scheithauer, W., Figer, A., Wong, R., Koski, S., Lichinitser, M., Yang, T.S., Rivera, F., Couture, F., Sirzén, F., Saltz, L. 2008. Randomized phase III study of capecitabine plus oxaliplatin compared with fluorouracil/folinic acid plus oxaliplatin as first-line therapy for metastatic colorectal cancer. Journal of Clinical Oncology, 26(12):2006-2012.

37. Chalmers, I.J., Höfler, H., Atkinson, M.J. 1999. Mapping of a cadherin gene cluster to a region of chromosome 5 subject to frequent allelic loss in carcinoma. Genomics, 57(1):160-163.

38. Charfi, C., Edouard, E., Rassart, E. 2014. Identification of GPM6A and GPM6B as potential new human lymphoid leukemia-associated oncogenes. Cellular Oncology, 37(3):179-191. 
39. Charnsangavej, C., Clary, B., Fong, Y., Grothey, A., Pawlik, T.M., Choti, M.A. 2006. Selection of Patients for Resection of Hepatic Colorectal Metastases: Expert Consensus Statement. Annals of Surgical Oncology, 13(10): 1261-1268.

40. Chen, H.X., Mooney, M., Boron, M., Vena, D., Mosby, K., Grochow, L. 2006. Phase II multicenter trial of bevacizumab plus fluorouracil and leucovorin in patients with advanced refractory colorectal cancer: an NCI Treatment Referral Center Trial TRC-0301. Journal of Clinical Oncology, 24: 3354-3360.

41. Chessa, A., Civitelli, S., Bernini, A., Tanzini, G., Carraro, F., Pucci, A., Vannoni, D. 2008. Adenosine kinase gene expression in human colorectal cancer. Nucleosides Nucleotides Nucleic Acids, 27(6):750-754.

42. Chibaudel, B., Maindrault-Goebel, F., Lledo, G., Mineur, L., André, T., Bennamoun, M., Mabro, M., Artru, P., Carola, E., Flesch, M., Dupuis, O., Colin, P., Larsen, A.K., Afchain, P., Tournigand, C., Louvet, C., de Gramont, A. 2009. Can chemotherapy be discontinued in unresectable metastatic colorectal cancer? The GERCOR OPTIMOX2 Study. Journal of Clinical Oncology, 27(34):5727-5733.

43. Chibaudel, B., Tournigand, C., André, T. and de Gramont, A. 2012. Therapeutic strategy in unresectable metastatic colorectal cancer. Therapy Advances in Medical Oncology, 4(2): 7589.

44. Choti, M.A. 2009. Chemotherapy-associated hepatotoxicity: do we need to be concerned? Annals of Surgical Oncology, 16(9):2391-2394.

45. Choti, M.A., Sitzmann, J.V., Tiburi, M.F., Sumetchotimetha, W., Rangsin, R., Schulick, R.D., Lillemoe, K.D., Yeo, C.J. and Cameron, J.L. 2002. Trends in Long-Term Survival Following Liver Resection for Hepatic Colorectal Metastases. Annals of Surgery, 235(6):759-766.

46. Chua, H.K., Sondenaa, K., Tsiotos, G.G. 2004. Concurrent vs. staged colectomy and hepatectomy for primary colorectal cancer with synchronous hepatic metastases. Diseases of the Colon and Rectum, 47:1310-1316.

47. Cohen, S.J., Punt, C.J.A., Iannotti, N., Saidman, B.H., Sabbath, K.D., Gabrail, N.Y., Picus, Y., Morse, M., Mitchell, E., Miller, M.C., Doyle, G.V., Tissing, H., Terstappen, W.M.M. and Meropol, N. 2008. Relationship of Circulating Tumor Cells to Tumor Response, ProgressionFree Survival, and Overall Survival in Patients With Metastatic Colorectal Cancer. Journal of Clinical Oncology, 26(19):3213-3221.

48. Colorectal cancer statistics. Globocan 2018. https://gco.iarc.fr/today/data/factsheets/cancers/10_8_9-Colorectum-fact-sheet.pdf

49. Colucci, G., Gebbia, V., Paoletti, G., Giuliani, F., Caruso, M., Gebbia, N., Cartenì, G., Agostara, B., Pezzella, G., Manzione, L., Borsellino, N., Misino, A., Romito, S., Durini, E., Cordio, S., Di Seri, M., Lopez, M., Maiello, E., Montemurro, S., Cramarossa, A., Lorusso, V., Di Bisceglie, M., Chiarenza, M., Valerio, M.R., Guida, T., Leonardi, V., Pisconti, S., Rosati, G., Carrozza, F., Nettis, G., Valdesi, M., Filippelli, G., Fortunato, S., Mancarella, S., Brunetti, C. 2005. Phase III randomized trial of FOLFIRI versus FOLFOX4 in the treatment of advanced colorectal cancer: a multicenter study of the Gruppo Oncologico Dell'Italia Meridionale. Journal of Clinical Oncology, 23(22): 4866-4875.

50. Cortés-Ciriano, I., Lee, J.J., Xi, R., Jain, D., Jung, Y.L., Yang, L., Gordenin, D., Klimczak, L.J., Zhang, C.Z., Pellman, D.S., PCAWG Structural Variation Working Group, Park, P.J., PCAWG Consortium. 2020. Comprehensive analysis of chromothripsis in 2,658 human cancers using whole-genome sequencing. Nature Genetics, 52:331-341.

51. Cunningham, D., Humblet, Y., Siena, S., Khayat, D., Bleiberg, H., Santoro, A. 2004. Cetuximab monotherapy and cetuximab plus irinotecan in irinotecan refractory metastatic colorectal cancer, New England Journal of Medicine, 351:337-345.

52. Daneberga, Z., Berzina, D., Borosenko, V., Krumina, Z., Kokaine-Sapovalova, L., Gardovskis, A., Berga-Svitina, E., Gardovskis, J., Miklasevics, E. 2019. Pathogenic APC Variants in Latvian Familial Adenomatous Polyposis Patients. Medicina, 55(10):612. 
53. de Gramont, A. 2008. Oxaliplatin stop-and-go treatment regimens. United States Patent Application Publication. Pub. No. 2008/0085881 A1.

54. de Gramont, A., Figer, A., Seymour, M., Homerin, M., Hmissi, A., Cassidy, J., Boni, C., CortesFunes, H., Cervantes, A., Freyer, G., Papamichael, D., Le Bail, N., Louvet, C., Hendler, D., de Braud, F., Wilson, C., Morvan, F. and Bonetti A. 2000. Leucovorin and Fluorouracil With or Without Oxaliplatin as First-Line Treatment in Advanced Colorectal Cancer. Journal of Clinical Oncology, 18(16):2938-2947.

55. De Gramont, A., Van Cutsem, E., Tabernero, J., Moore, M.J., Cunningham, D., Rivera, F., Im, S., Makrutzki, M., Shang, A., Hoff, P.M. 2011. AVANT: Results from a randomized, three-arm multinational phase III study to investigate bevacizumab with either XELOX or FOLFOX4 versus FOLFOX4 alone as adjuvant treatment for colon cancer. Journal of Clinical Oncology, 29(4s): abstr 362 .

56. de Haas, R.J., Wicherts, D.A., Flores, E., Ducreux, M., Lévi, F., Paule, B., Azoulay, D., Castaing, D., Lemoine, A., Adam, R. 2010. Tumor marker evolution: comparison with imaging for assessment of response to chemotherapy in patients with colorectal liver metastases. Annals of Surgical Oncology, 17(4):1010-1023.

57. De Roock, W., Claes, B., Bernasconi, D., De Schutter, J., Biesmans, B., Fountzilas, G., Kalogeras, K.T., Kotoula, V., Papamichael, D., Laurent-Puig, P., Penault-Llorca, F., Rougier, P., Vincenzi, B., Santini, D., Tonini, G., Cappuzzo, F., Frattini, M., Molinari, F., Saletti, P., De Dosso, S., Martini, M., Bardelli, A., Siena, S., Sartore-Bianchi, A., Tabernero, J., Macarulla, T., Di Fiore, F., Gangloff, A.O., Ciardiello, F., Pfeiffer, P., Qvortrup, C., Hansen, T.P., Van Cutsem, E., Piessevaux, H., Lambrechts, D., Delorenzi, M., Tejpar, S. 2010. Effects of KRAS, BRAF, NRAS, and PIK3CA mutations on the efficacy of cetuximab plus chemotherapy in chemotherapy-refractory metastatic colorectal cancer: a retrospective consortium analysis. Lancet Oncology, 11:753-762.

58. De Roock, W., De Vriendt, V., Normanno, N., Ciardiello, F., Tejpar, S. 2011. KRAS, BRAF, PIK3CA, and PTEN mutations: implications for targeted therapies in metastatic colorectal cancer. Lancet Oncology, 12:594-603.

59. Desai, D.C., Zervos, E.E., Arnold, M.W., Burak, W.E.Jr., Mantil, J., Martin, E.W.Jr. 2003. Positron emission tomography affects surgical management in recurrent colorectal cancer patients. Annals of Surgical Oncology, 10(1):59-64.

60. Di Nicolantonio, F., Martini, M., Molinari, F., Sartore-Bianchi, A., Arena, S., Saletti, P., De Dosso, S., Mazzucchelli, L., Frattini, M., Siena, S., Bardelli, A. 2008. Wild-type BRAF is required for response to panitumumab or cetuximab in metastatic colorectal cancer. Journal of Clinical Oncology, 26:5705-5712.

61. Diehl, F., Li, M., Dressman, D., He, Y., Shen, D., Szabo, S., Diaz, L.A., Goodman, S.N., David, K.A., Juhl, H., Kinzler, K.W., Vogelstein, B. 2005. Detection and quantification of mutations in the plasma of patients with colorectal tumors. Proceedings of the National Academy of Sciences of the United States of America, 8;102(45):16368-16373.

62. Diehl, F., Schmidt, K., Choti, M.A., Romans, K., Goodman, S., Li, M., Thornton, K., Agrawal, N., Sokoll, L., Szabo, S.A., Kinzler, K.W., Vogelstein, B., Diaz, L.A. 2008. Circulating mutant DNA to assess tumor dynamics. Nature Medicine, 14:985-990.

63. Douillard, J., Siena, S., Cassidy, J., Tabernero, J., Burkes, R.L., Barugel, M.E., Humblet, Y., Cunningham, D., Xu, F., Krishnan, K. 2011. Final results from PRIME: Randomized phase III study of panitumumab (pmab) with FOLFOX4 for first-line metastatic colorectal cancer (mCRC). Journal of Clinical Oncology, 29:abstr 3510.

64. Douillard, J.Y., Cunningham, D., Roth, A.D., Navarro, M., James, R.D., Karasek, P., Jandik, P., Iveson, T., Carmichael, J, Alakl, M., Gruia, G., Awad, L., Rougier, P. 2000. Irinotecan combined with fluorouracil compared with fluorouracil alone as first-line treatment for metastatic colorectal cancer: a multicentre randomised trial. Lancet, 355:1041-1047. 
65. Douillard, J.Y., Oliner, K.S., Siena, S., Tabernero, J., Burkes, R., Barugel, M., Humblet, Y., Bodoky, G., Cunningham, D., Jassem, J., Rivera, F., Kocákova, I., Ruff, P., BłasińskaMorawiec, M., Šmakal, M., Canon, J.L., Rother, M., Williams, R., Rong, A., Wiezorek, J., Sidhu, R., Patterson, S.D. 2013. Panitumumab-FOLFOX4 treatment and RAS mutations in colorectal cancer. New England Journal of Medicine, 369(11):1023-1034.

66. Douillard, J.Y., Siena, S., Cassidy, J., Tabernero, J., Burkes, R., Barugel, M., Humblet, Y., Bodoky, G., Cunningham, D., Jassem, J., Rivera, F., Kocákova, I., Ruff, P., BłasińskaMorawiec, M., Šmakal, M., Canon, J.L., Rother, M., Oliner, K.S., Wolf, M., Gansert, J. 2010. Randomized, Phase III Trial of Panitumumab With Infusional Fluorouracil, Leucovorin, and Oxaliplatin (FOLFOX4) Versus FOLFOX4 Alone As First-Line Treatment in Patients With Previously Untreated Metastatic Colorectal Cancer: The PRIME Study. Journal of Clinical Oncology, 28(31):4697-4705.

67. Ducreux, M., Bennouna, J., Hebbar, M., Ychou, M., Lledo, G., Conroy, T., Adenis, A., Faroux, R., Rebischung, C., Bergougnoux, L., Kockler, L., Douillard, J.Y. GI Group of the French AntiCancer Centers. 2011. Capecitabine plus oxaliplatin (XELOX) versus 5-fluorouracil/leucovorin plus oxaliplatin (FOLFOX-6) as first-line treatment for metastatic colorectal cancer. International Journal of Cancer, 128(3):682-690.

68. Duffy, M.J., van Dalen, A., Haglund, C., Hansson, L., Holinski-Feder, E., Klapdor, R., Lamerz, R., Peltomaki, P., Sturgeon, C., Topolcan, O. 2007. Tumour markers in colorectal cancer: European Group on Tumour Markers (EGTM) guidelines for clinical use. European Journal of Cancer, 43(9):1348-1360

69. Duffy, M.J., vanDalen, A., Haglund, C., van Dalen, A, Haglund, C., Hansson, L., Klapdor, R., Lamerz, R., Nilsson, O., Sturgeon, C., Topolcan, O. 2003. Clinical utility of biochemical markers in colorectal cancer: European Group on Tumour Markers (EGTM) guidelines. European Journal of Cancer, 39:718-727.

70. Eisenhauer, E.A., Therasse, P., Bogaerts, J., Schwartz, L.H., Sargent, D., Ford, R., Dancey, J., Arbuck, S., Gwyther, S., Mooney, M., Rubinstein, L., Shankar, L., Dodd, L., Kaplan, R., Lacombe, D., Verweij, J. 2009. New response evaluation criteria in solid tumours: Revised RECIST guideline (version 1.1). European Journal of cancer, 45:228-247.

71. Elias, D., Detroz, B., Lasser, P., Plaud, B., Jerbi, G. 1995. Is simultaneous hepatectomy and intestinal anastomosis safe? American Journal of Surgery, 169:254-260.

72. Falcone, A., Ricci, S., Brunetti, I., Pfanner, E., Allegrini, G., Barbara, C., Crinò, L., Benedetti, G., Evangelista, W., Fanchini, L., Cortesi, E., Picone, V., Vitello, S., Chiara, S., Granetto, C., Porcile, G., Fioretto, L., Orlandini, C., Andreuccetti, M., Masi, G. Gruppo Oncologico Nord Ovest. 2007. Phase III trial of infusional fluorouracil, leucovorin, oxaliplatin, and irinotecan (FOLFOXIRI) compared with infusional fluorouracil, leucovorin, and irinotecan (FOLFIRI) as first-line treatment for metastatic colorectal cancer: the Gruppo Oncologico Nord Ovest. Journal of Clinical Oncology, 25(13):1670-1676.

73. Fearon, E.R. and Vogelstein, B. 1990. A genetic model for colorectal tumorigenesis. Cell, 61(5):759-767.

74. Ferlay, J., Colombet, M., Soerjomataram, I., Dyba, T., Randi, G., Bettio, M., Gavin, A., Visser, O., Bray, F. Cancer incidence and mortality patterns in Europe: Estimates for 40 countries and 25 major cancers in 2018. 2018. European Journal of Cancer, 103:356-387.

75. Ferlay, J., Parkin, D.M., Steliarova-Foucher, E. 2010. Estimates of cancer incidence and mortality in Europe in 2008. European Journal of Cancer, 46(4):765-781.

76. Fessler, E., Drost, J., van Hooff, S.R., Linnekamp, J.F., Wang, X., Jansen, M., De Sousa, E., Melo, F., Prasetyanti, P.R., IJspeert, J.E., Franitza, M., Nürnberg, P., van Noesel, C.J., Dekker, E., Vermeulen, L., Clevers, H., Medema, J.P. 2016. TGF $\beta$ signaling directs serrated adenomas to the mesenchymal colorectal cancer subtype. EMBO Molecular Medicine, 8(7):745-760. 
77. Filiz, A.I., Sucullu, I., Kurt, Y., Karakas, D.O., Gulec, B., Akin, M.L. 2009. Persistent high postoperative carcinoembryonic antigen in colorectal cancer patients- is it important? Clinics, 64(4):287-294.

78. Fleischhacker, M. and Schmidt, B. 2007. Circulating nucleic acids (CNAs) and cancer - a survey. Biochimica and Biophysica Acta, 1775:181-232.

79. Fleming, N.I., Jorissen, R.N., Mouradov, D., Christie, M., Sakthianandeswaren, A., Palmieri, M., Day, F., Li, S., Tsui, C., Lipton, L., Desai, J., Jones, I.T., McLaughlin, S., Ward, R.L., Hawkins, N.J., Ruszkiewicz, A.R., Moore, J., Zhu, H.J., Mariadason, J.M., Burgess, A.W., Busam, D., Zhao, Q., Strausberg, R.L., Gibbs, P., Sieber, O.M. 2013. SMAD2, SMAD3 and SMAD4 mutations in colorectal cancer. Cancer Research, 73(2):725-735.

80. Fong, Y., Cohen, A.M., Fortner, J.G. 1997. Liver resection for colorectal metastases. Journal of clinical oncology, 15:938-946.

81. Fong, Y., Fortner, J., Sun, R.L., Brennan, M.F., Blumgart, L.H. 1999. Clinical score for predicting recurrence after hepatic resection for metastatic colorectal cancer: analysis of 1001 consecutive cases. Annals of Surgery, 230(3): 309-321.

82. Fontana, M.C., Marconi, G., Feenstra, J.D.M., Fonzi, E., Papayannidis, C., Ghelli Luserna di Rorá, A., Padella, A., Solli, V., Franchini, E., Ottaviani, E., Ferrari, A., Baldazzi, C., Testoni, N., Iacobucci, I., Soverini, S., Haferlach, T., Guadagnuolo, V., Semerad, L., Doubek, M., Steurer, M., Racil, Z., Paolini, S., Manfrini, M., Cavo, M., Simonetti, G., Kralovics, R., Martinelli, G. 2018. Chromothripsis in acute myeloid leukemia: biological features and impact on survival. Leukemia, 10, 1038/leu.2017.351.

83. Frattini, M., Saletti, P., Romagnani, E., Martin, V., Molinari, F., Ghisletta, M., Camponovo, A., Etienne, L.L., Cavalli, F., Mazzucchelli, L. 2007. PTEN loss of expression predicts cetuximab effi cacy in metastatic colorectal cancer patients. British Journal of Cancer, 97:11391145 .

84. Fujita, S., Akasu, T., Moriya, Y. 2000. Resection of synchronous liver metastases from colorectal cancer. Japanese Journal of Clinical Oncology, 30:7-11.

85. Funke, S., Brenner, H., Chang-Claude, J. 2008. Pharmacogenetics in colorectal cancer: a systematic review. Pharmacogenomics, 9:1079-1099.

86. Gazzaniga, P., Raimondi, C., Gradilone, A., Di Seri, M., Longo, F., Cortesi, E., Frati, L. 2011. Circulating tumor cells, colon cancer and bevacizumab: the meaning of zero. Annals of Oncology, 22(8):1929-1930.

87. Geissler, M., Martens, U.M., Knorrenschild, R., Greeve, J., Florschuetz, A., Tannapfel, A., Wessendorf, S., Seufferlein, T., Kanzler, S., Heinemann, V., Held, S., Reinacher-Schick, A. 2017. mFOLFOXIRI + panitumumab versus FOLFOXIRI as first-line treatment in patients with RAS wild-type metastatic colorectal cancer $\mathrm{m}(\mathrm{CRC})$ : A randomized phase II VOLFI trial of the AIO (AIO-KRK0109). Annals of Oncology, 28(5):v158-v208.

88. Giacchetti, S., Perpoint, B., Zidani, R., Le Bail, N., Faggiuolo, R., Focan, C., Chollet, P., Llory, J.F., Letourneau, Y., Coudert, B., Bertheaut-Cvitkovic, F., Larregain-Fournier, D., Le Rol, A., Walter, S., Adam, R., Misset, J.L., Lévi, F. 2000. Phase III multicenter randomized trial of oxaliplatin added to chronomodulated fluorouracil-leucovorin as firstline treatment of metastatic colorectal cancer. Journal of Clinical Oncology, 18:136-147.

89. Giantonio, B.J., Catalano, P.J., Meropol, N.J., O’Dwyer, P.J., Mitchell, E.P., Alberts, S.R. 2007. Bevacizumab in combination with oxaliplatin, fluorouracil, and leucovorin (FOLFOX4) for previously treated metastatic colorectal cancer: results from the Eastern Cooperative Oncology Group Study E3200. Journal of Clinical Oncology, 25:1539-1544.

90. Giglioni, S., Leoncini, R., Aceto, E., Chessa, A., Civitelli, S., Bernini, A., Tanzini, G., Carraro, F., Pucci, A., Vannoni, D. 2008. Adenosine kinase gene expression in human colorectal cancer. Nucleosides Nucleotides Nucleic Acids, 27(6):750-754. 
91. Goldberg, R.M., Sargent, D.J., Morton, R.F., Fuchs, C.S., Ramanathan, R.K., Williamson, S.K., Findlay, B.P., Pitot, H.C. and Alberts, S.R. 2004. A randomized controlled trial of fluorouracil plus leucovorin, irinotecan, and oxaliplatin combinations in patients with previously untreated metastatic colorectal cancer. Journal of Clinical Oncology, 22:23-30.

92. Goldstein, M.J. and Mitchell, E.P. 2005. Carcinoembryonic antigen in the staging and followup of patients with colorectal cancer. Cancer Investigation, 23:338-351.

93. Grothey, A., Deschler, B., Kroening, H. 2002. Phase III study of bolus 5-fluorouracil (5-FU)/ folinic acid (FA) (Mayo) vs weekly high-dose 24h 5-FU infusion/FA + oxaliplatin (OXA) (FUFOX) in advanced colorectal cancer (ACRC). Proceedings of American Society of Clinical Oncology, 21(129a):3530.

94. Grothey, A., Van Cutsem, E., Sobrero, A., Siena, S., Falcone, A., Ychou, M., Humblet, Y, Bouché, O., Mineur, L., Barone, C., Adenis, A., Tabernero, J., Yoshino, T., Lenz, H.J., Goldberg, R.M., Sargent, D.J., Cihon, F., Cupit, L., Wagner, A., Laurent, D., CORRECT Study Group. 2013. Regorafenib monotherapy for previously treated metastatic colorectal cancer (CORRECT): an international, multicentre, randomised, placebo- controlled, phase 3 trial. Lancet, 381:303-312.

95. Gruenberger, B., Tamandl, D., Schueller, J., Scheithauer, W., Zielinski, C., Herbst, F., Gruenberger, T. 2008. Bevacizumab, capecitabine, and oxaliplatin as neoadjuvant therapy for patients with potentially curable metastatic colorectal cancer. Journal of Clinical Oncology, 26(11):1830-1835.

96. Guan, M., Xu, C., Zhang, F., Ye, C. 2009. Aberrant methylation of EphA7 in human prostate cancer and its relation to clinicopathologic features. International Journal of Cancer, 124(1):8894.

97. Guinney, J., Dienstmann, R., Wang, X., de Reyniès, A., Schlicker, A., Soneson, C., Marisa, L., Roepman, P., Nyamundanda, G., Angelino, P., Bot, B.M., Morris, J.S., Simon, I.M., Gerster, S., Fessler, E., De Sousa, E., Melo, F., Missiaglia, E., Ramay, H., Barras, D., Homicsko, K., Maru, D., Manyam, G.C., Broom, B., Boige, V., Perez-Villamil, B., Laderas, T., Salazar, R., Gray, J.W., Hanahan, D., Tabernero, J., Bernards, R., Friend, S.H., Laurent-Puig, P., Medema, J.P., Sadanandam, A., Wessels, L., Delorenzi, M., Kopetz, S., Vermeulen, L., Tejpar, S. 2015. The consensus molecular subtypes of colorectal cancer. Nature Medicine, 21(11):1350-1356.

98. Haigis, K.M., Kendall, K.R., Wang, Y., Cheung, A., Haigis, M.C., Glickman, J.N., NiwaKawakita, M., Sweet-Cordero, A., Sebolt-Leopold, J., Shannon, K.M., Settleman, J., Giovannini, M., Jacks, T. 2008. Differential effects of oncogenic K-Ras and N-Ras on proliferation, differentiation and tumor progression in the colon. Nature Genetics, 40: 600-608.

99. Hamauchi, S., Yamazaki, K., Masuishi, T., Kito, Y., Komori, A., Tsushima, T., Narita, Y., Todaka, A., Ishihara, M., Yokota, T., Tanaka, T., Machida, N., Kadowaki, S., Fukutomi, A., Ura, T., Onozawa, Y., Ando, M., Tajika, M., Muro, K., Yasui, H., Mori, K., Taniguchi, H. 2017. Neutropenia as a Predictive Factor in Metastatic Colorectal Cancer Treated With TAS-102. Clinical Colorectal Cancer, 16(1):51-57.

100. Hashimoto, K., Yamada, Y., Semi, K., Yagi, M., Tanaka, A., Itakura, F., Aoki, H., Kunisada, T., Woltjen, K., Haga, H., Sakai, Y., Yamamoto, T., Yamada, Y. 2017. Cellular contextdependent consequences of Apc mutations on gene regulation and cellular behavior. PNAS, 114(4):758-763.

101. Hayashi, M., Inoue, Y., Komeda, K., Shimizu, T., Asakuma, M., Hirokawa, F., Miyamoto, Y., Okuda, J., Takeshita, A., Shibayama, Y., Tanigawa, N. 2010. Clinicopathological analysis of recurrence patterns and prognostic factors for survival after hepatectomy for colorectal liver metastasis. BMC Surgery, 10:27.

102. He, B., Li, T., Guan, L., Liu, F.E., Chen, X.M., Zhao, J., Lin, S., Liu, Z.Z., Zhang, H.Q. 2016. CTNNA3 is a tumor suppressor in hepatocellular carcinomas and is inhibited by miR-425. Oncotarget, 7(7):8078-8089. 
103. He, W., Li, X., Xu, S., Ai, J., Gong, Y., Gregg, J.L., Guan, R., Qiu, W., Xin, D., Gingrich, J.R., Guo, Y., Chang, G. 2013. Aberrant methylation and loss of CADM2 tumor suppressor expression is associated with human renal cell carcinoma tumor progression. Biochemical and Biophysical Research Communications, 435(4):526-532.

104. Hecht, J.R., Mitchell, E., Chidiac, T., Scroggin, C., Hagenstad, C., Spigel, D., Marshall, J., Cohn, A., McCollum, D., Stella, P., Deeter, R., Shahin, S., Amado, R.G. 2009. A randomized phase IIIB trial of chemotherapy, bevacizumab, and panitumumab compared with chemotherapy and bevacizumab alone for metastatic colorectal cancer. Journal of Clinical Oncology, 27(5):672-680.

105. Hecht, J.R., Trarbach, T., Hainsworth, J.D., Major, P., Jäger, E., Wolff, R.A. 2011. Randomized, placebo-controlled, phase III study of first-line oxaliplatin-based chemotherapy plus PTK787/ ZK 222584, an oral vascular endothelial growth factor receptor inhibitor, in patients with metastatic colorectal adenocarcinoma. Journal of Clinical Oncology, 29:1997-2003.

106. Hochster, H.S., Hart, L.L., Ramanathan, R.K., Childs, B.H., Hainsworth, J.D., Cohn, A.L., Wong, L., Fehrenbacher, L., Abubakr, Y., Saif, M.W., Schwartzberg, L., Hedrick, E. 2008. Safety and efficacy of oxaliplatin and fluoropyrimidine regimens with or without bevacizumab as first-line treatment of metastatic colorectal cancer: results of the TREE Study. Journal of Clinical Oncology, 26(21):3523-3529.

107. Holland, A.J., Cleveland, D.W. 2012. Chromoanagenesis and cancer: mechanisms and consequences of localized, complex chromosomal rearrangements. Nature Medicine, 18(11):1630-1638.

108. Hou, L., Chen, M., Zhao, X., Li, J., Deng, S., Hu, J., Yang, H., Jiang, J. 2016. FAT4 functions as a tumor suppressor in triple-negative breast cancer. Tumour Biology, 37(12):16337-16343.

109. Houle, A.A., Gibling, H., Lamaze, F.C., Edgington, H.A., Soave, D., Fave, M.J., Agbessi, M., Bruat, V., Stein, L.D., Awadalla, P. 2018. Aberrant PRDM9 expression impacts the pan-cancer genomic landscape. Genome Research, 28(11):1611-1620.

110. Huang, R.S., Johnatty, S.E., Gamazon, E.R., Im, H.K., Ziliak, D., Duan, S., Zhang, W., Kistner, E.O., Chen, P., Beesley, J., Mi, S., O'Donnell, P.H., Fraiman, Y.S., Das, S., Cox, N.J., Lu, Y., Macgregor, S., Goode, E.L., Vierkant, R.A., Fridley, B.L., Hogdall, E., Kjaer, S.K., Jensen, A., Moysich, K.B., Grasela, M., Odunsi, K., Brown, R., Paul, J., Lambrechts, D., Despierre, E., Vergote, I., Gross, J., Karlan, B.Y., Defazio, A., Chenevix-Trench, G. Australian Ovarian Cancer Study Group, Dolan, M.E. 2011. Platinum sensitivity-related germline polymorphism discovered via a cell-based approach and analysis of its association with outcome in ovarian cancer patients. Clinical Cancer Research, 17(16):5490-5500.

111. Hurwitz, H., Fehrenbacher, L., Novotny, W., Cartwright, T., Hainsworth, J., Heim, W., Berlin, J., Baron, A., Griffing, S., Holmgren, E., Ferrara, N., Fyfe, G., Rogers, B., Ross, R., Kabbinavar, F. 2004. Bevacizumab plus irinotecan, fluorouracil, and leucovorin for metastatic colorectal cancer. New England Journal of Medicine, 350: 2335-2342.

112. Hurwitz, H.I., Yi, J., Ince, W., Novotny, W.F., Rosen, O. 2009. The clinical benefit of bevacizumab in metastatic colorectal cancer is independent of K-ras mutation status: analysis of a phase III study of bevacizumab with chemotherapy in previously untreated metastatic colorectal cancer. Oncologist, 14: 22-28.

113. Iacopetta, B.J., Welch, J., Soong, R., House, A.K., Zhou, X.P., Hamelin, R. 1998. Mutation of the transforming growth factor-beta type II receptor gene in right-sided colorectal cancer: relationship to clinicopathological features and genetic alterations. Journal of Pathology, 184(4):390-395.

114. Innocenti, F., Undevia, S.D., Iyer, L., Chen, P.X., Das, S., Kocherginsky, M., Karrison, T., Janisch, L., Ramírez, J., Rudin, C.M., Vokes, E.E., Ratain, M.J. 2004. Genetic variants in the UDP-glucuronosyltransferase $1 \mathrm{~A} 1$ gene predict the risk of severe neutropenia of irinotecan. Journal of Clinical Oncology, 22(8):1382-1388. 
115. Jao, T.M., Tsai, M.H., Lio, H.Y., Weng, W.T., Chen, C.C., Tzeng, S.T., Chang, C.Y., Lai, Y.C., Yen, S.J., Yu, S.L., Yang, Y.C. 2014. Protocadherin 10 suppresses tumorigenesis and metastasis in colorectal cancer and its genetic loss predicts adverse prognosis. International Journal of Cancer, 135(11):2593-2603.

116. Jasperson, K.W., Tuohy, T.M., Neklason, D.W., Burt, R.W. Hereditary and familial colon cancer. 2010. Gastroenterology, 138(6):2044-2058.

117. Jass, J.R. 2007. Classification of colorectal cancer based on correlation of clinical, morphological and molecular features. Histopathology, 50(1):113-130.

118. Jenkins, L.T., Millikan, K.W., Bines, S.D. 1997. Hepatic resection for metastatic colorectal cancer. American Surgery, 63:605-610.

119. Jones, S., Chen, W., Parmigiani, G., Diehl, F., Beerenwinkel, N., Antal, T., Traulsen, A., Nowak, M.A., Siegel, C., Velculescu, V.E., Kinzler, K.W., Vogelstein, B., Willis, J., and Markowitz, S.D. 2008. Comparative lesion sequencing provides insights into tumor evolution. PNAS, 105(11):4283-4288.

120. Jones, S., Wood, L.D., Sjöblom,T., Parsons, D.W., Lin, J., Barber, T.D., Mandelker, D., Leary, R.J., Ptak, J., Silliman, N., Szabo, S., Buckhaults, P., Farrell, C., Meeh, P., Markowitz, S.D., Willis, J., Dawson, D., Willson, J.K., Gazdar, A.F., Hartigan, J., Wu, L., Liu, C., Parmigiani, G., Park, B.H., Bachman, K.E., Papadopoulos, N., Vogelstein, B., Kinzler, K.W., Velculescu, V.E. 2006. The consensus coding sequences of human breast and colorectal cancers. Science, 314:268-74

121. Jonker, D.J., O'Callaghan, C.J., Karapetis, C.S., Zalcberg, J.R., Tu, D., Au, H.J. 2007. Cetuximab for the treatment of colorectal cancer. New England Journal of Medicine, 357:20402048 .

122. Kabbinavar, F.F., Hambleton, J., Mass, R.D., Hurwitz, H.I., Bergsland, E., Sarkar, S. 2005. Combined analysis of efficacy: the addition of bevacizumab to fluorouracil/leucovorin improves survival for patients with metastatic colorectal cancer. Journal of Clinical Oncology, 23(16):3706-3712.

123. Kabbinavar, F.F., Schulz, J., McCleod, M., Patel, T., Hamm, J.T., Hecht, J.R. 2005. Addition of bevacizumab to bolus fluorouracil and leucovorin in first-line metastatic colorectal cancer. Results of a randomized phase II trial. Journal of Clinical Oncology, 23:3697-3705.

124. Kang, B.W., Kim, T.W., Lee, J.L., Ryu, M.H., Chang, H.M., Yu, C.S. 2009. Bevacizumab plus FOLFIRI or FOLFOX as third-line or later treatment in patients with metastatic colorectal cancer after failure of 5-fluorouracil, irinotecan, and oxaliplatin: a retrospective analysis. Medical Oncology, 26:32-37.

125. Kao, W.T., Wang, Y., Kleinman, J.E., Lipska, B.K., Hyde, T.M., Weinberger, D.R., Law, A.J. 2010. Common genetic variation in Neuregulin 3 (NRG3) influences risk for schizophrenia and impacts NRG3 expression in human brain. Proceedings of the National Academia of Sciences of the United States of America, 107(35):15619-15624.

126. Karapetis, C.S., Khambata-Ford, S., Jonker, D.J., O'Callaghan, C.J., Tu, D., Tebbutt, N.C., Simes, R.J., Chalchal, H., Shapiro, J.D., Robitaille, S., Price, T.J., Shepherd, L., Au, H.J., Langer, C., Moore, M.J., Zalcberg, J.R. 2008. K-ras mutations and benefit from cetuximab in advanced colorectal cancer. New England Journal of Medicine, 359(17):1757-1765.

127. Kaufman, B., Laitman, Y., Gronwald, J., Winqvist, R., Irmejs, A., Lubinski, J., Pylkäs, K., Gardovskis, J., Miklasevics, E., Friedman, E. 2009. Haplotypes of the I157T CHEK2 germline mutation in ethnically diverse populations. Familial Cancer, 8(4):473-478.

128. Kim, K.P., Kim, J.E., Hong, Y.S., Ahn, S.M., Chun, S.M., Hong, S.M., Jang, S.J., Yu, C.S., Kim, J.C., Kim, T.W. 2017. Paired Primary and Metastatic Tumor Analysis of Somatic Mutations in Synchronous and Metachronous Colorectal Cancer. Cancer Research and Treatment, 49(1):161-167. 
129. Kishi Y, Zorzi D, Contreras CM, Maru DM, Kopetz S, Ribero D, Motta M, Ravarino N, Risio M, Curley SA, Abdalla EK, Capussotti L, Vauthey JN. 2010. Extended preoperative chemotherapy does not improve pathologic response and increases postoperative liver insufficiency after hepatic resection for colorectal liver metastases. Annals of Surgical Oncology, 17(11):2870-2876.

130. Kloosterman, W.P., Coebergh van den Braak, R.R.J., Pieterse, M., van Roosmalen, M.J., Sieuwerts, A.M., Stangl, C., Brunekreef, R., Lalmahomed, Z.S., Ooft, S., van Galen, A., Smid, M., Lefebvre, A., Zwartkruis, F., Martens, J.W.M., Foekens, J.A., Biermann, K., Koudijs, M.J., Ijzermans, J.N.M., Voest, E.E. 2017. A Systematic Analysis of Oncogenic Gene Fusions in Primary Colon Cancer. Cancer Research, 77(14):3814-3822.

131. Kohne, C., Bajetta, E., Lin, E., Valle, J.W., Van Cutsem, E., Hecht, J.R. 2007. Final results of CONFIRM 2: a multinational, randomized, double-blind, phase III study in 2nd line patients (pts) with metastatic colorectal cancer (mCRC) receiving FOLFOX4 and PTK787/ZK 222584 (PTK/ZK) or placebo. Journal of Clinical Oncology, 25(18): 4033.

132. Kohne, C., Mineur, L., Greil, R., Letocha, H., Thaler, J., Hofheinz, R., Fernebro, E., Gamelin, E., Wright, L., Karthaus, M. 20060314 Study Group. 2010. Primary analysis of a phase II study (20060314) combining first-line panitumumab (pmab) with FOLFIRI in the treatment of patients (pts) with metastatic colorectal cancer (mCRC). 2010 Gastrointestinal Cancers Symposium. Abstract No:414.

133. Kohne, C.H., Van Cutsem, E., Wils, J.A., Bokemeyer, C., El-Serefi, M., Lutz, M., Lorenz, M., Reichardt, P., Rückle-Lanz, H., Frickhofen, N., Fuchs, R., Mergenthaler, H.G., Langenbuch, T., Vanhoefer, U., Rougier, P., Voigtmann, R., Müller, L., Genicot, B., Anak, O., Nordlinger, B. European Organisation for Research and Treatment of Cancer Gastrointestinal Group. 2003. Irinotecan improves the activity of the AIO regimen in metastatic colorectal cancer: results of EORTC GI Group study 40986. Proceedings of American Society of Clinical Oncology, 22:254.

134. Koltsova, A.S., Pendina, A.A., Efimova, O.A., Chiryaeva, O.G., Kuznetzova, T.V., Baranov, V.S. 2019. On the Complexity of Mechanisms and Consequences of Chromothripsis: An Update. Frontline Genetics, 10:393.

135. Kopetz, S., Grothey, A., Yaeger, R., Van Cutsem, E., Desai, J., Yoshino, T., Wasan, H., Ciardiello, F., Loupakis, F., Hong, Y.S., Steeghs, N., Guren, T.K., Arkenau, H.T., GarciaAlfonso, P., Pfeiffer, P., Orlov, S., Lonardi, S., Elez, E., Kim, T.W., Schellens, J.H.M., Guo, C., Krishnan, A., Dekervel, J., Morris, V., Calvo Ferrandiz, A., Tarpgaard, L.S., Braun, M., Gollerkeri, A., Keir, C., Maharry, K., Pickard, M., Christy-Bittel, J., Anderson, L., Sandor, V., Tabernero, J. 2019. Encorafenib, Binimetinib, and Cetuximab in BRAF V600E-Mutated Colorectal Cancer. New England Journal of Medicine, 381(17):1632-1643.

136. Labianca, R., Sobrero, A., Isa, L., Cortesi, E., Barni, S., Nicolella, D. 2011. Intermittent versus continuous chemotherapy in advanced colorectal cancer: a randomised 'GISCAD' trial. Annals of Oncology, 22:1236-1242.

137. Langer, C., Kopit, J., Awad, M., Williams, K., Teegarden, P., Xu, L.S., Khambata-Ford. 2008. Mutations in patients with metastatic colorectal cancer receiving cetuximab in combination with irinotecan: results from the EPIC trial. ESMO 2008, Abstract 385P. Annals of Oncology, 19(8): viii133.

138. Laurent-Puig, P., Cayre, A., Manceau, G., Buc, E., Bachet, J.B., Lecomte, T., Rougier, P., Lievre, A., Landi, B., Boige, V., Ducreux, M., Ychou, M., Bibeau, F., Bouché, O., Reid, J., Stone, S. and Penault-Llorca, F. 2009. Analysis of PTEN, BRAF, and EGFR Status in Determining Benefit From Cetuximab Therapy in Wild-Type KRAS Metastatic Colon Cancer. Journal of Clinical Oncology, 27(35):5924-5930.

139. Le, D.T., Uram, J.N., Wang, H., Bartlett, B.R., Kemberling, H., Eyring, A.D., Skora, A.D., Luber, B.S., Azad, N.S., Laheru, D., Biedrzycki, B., Donehower, R.C., Zaheer, A., Fisher, G.A., Crocenzi, T.S., Lee, J.J., Duffy, S.M., Goldberg, R.M., de la Chapelle, A., Koshiji, M., Bhaijee, F., Huebner, T., Hruban, R.H., Wood, L.D., Cuka, N., Pardoll, 
D.M., Papadopoulos, N., Kinzler, K.W., Zhou, S., Cornish, T.C., Taube, J.M., Anders, R.A., Eshleman, J.R., Vogelstein, B., Diaz, L.A. 2015. PD-1 blockade in tumors with mismatch-repair deficiency. New England Journl of Medicine, 372:2509-2520.

140. Leary, R.J., Kinde, I., Diehl, F., Schmidt, K., Clouser, C., Duncan, C., Antipova, A., Lee, C., McKernan, K., De La Vega, F.M., Kinzler, K.W., Vogelstein, B., Diaz, L.A.Jr., Velculescu, V.E. 2010. Development of personalized tumor biomarkers using massively parallel sequencing. Science Translational Medicine, 24;2(20):20ra14.

141. Lee, H.S., Lee, H.K., Kim, H.S., Yang, H.K., Kim, W.H. 2003. Tumour suppressor gene expression correlates with gastric cancer prognosis. The Journal of Pathology, 200(1):39-46.

142. Lee, M.S., Menter, D.G., Kopetz, S. 2017. Right Versus Left Colon Cancer Biology: Integrating the Consensus Molecular Subtypes. Journal of National Comprehensive Cancer Network, 15(3):411-419.

143. Lenz, H.J., Lonardi, S., Zagonel, V., Van Cutsem, E., Limon, M.L., Wong, K.J.M., Hendlisz, A., Aglietta, M., Garcia-Alfonso, P., Neyns, B., Cardin, D.B., Spallanzani, A., Dragovich, T., Shah, U., Atasoy, A., Ledeine, J.M., Overman, M.J. 2019. Nivolumab (NIVO) + low-dose ipilimumab (IPI) as first-line (1L) therapy in microsatellite instability-high/DNA mismatch repair deficient (MSI-H/dMMR) metastatic colorectal cancer (mCRC): Clinical update. Journal of Clinical Oncology, 37(15): 3521-3521.

144. Li, H., Fan, X. Houghton, J. 2007. Tumor microenvironment: the role of the tumor stroma in cancer. Journal of Cellular Biochemistry, 101:805-815.

145. Li, J., Qin, S., Xu, R., Yau, T.C., Ma, B., Pan, H., Xu, J., Bai, Y., Chi, Y., Wang, L., Yeh, K.H., Bi, F., Cheng, Y., Le, A.T., Lin, J.K., Liu, T., Ma, D., Kappeler, C., Kalmus, J., Kim, T.W., CONCUR Investigators. 2015. Regorafenib plus best supportive care versus placebo plus best supportive care in Asian patients with previously treated metastatic colorectal cancer (CONCUR): a randomised, double-blind, placebo-controlled, phase 3 trial. Lancet Oncology,16:619-629.

146. Liang, H., Chen, H., Shen, Y., Feng, Q., Jin, W., Huang, W., Zeng, Y. 2004. A rare polymorphism of the COX7B2 gene in a Cantonese family with nasopharyngeal carcinoma. Science China Life Sciences, 47(5):449-453.

147. Lieu, C.H., Renfro, L.A., de Gramont, A., Meyers, J.P., Maughan, T.S, Seymour, M.T., Saltz, L., Goldberg, R.M., Sargent, D.J., Eckhardt, S.G. and Eng, C. 2014. Association of Age With Survival in Patients With Metastatic Colorectal Cancer: Analysis From the ARCAD Clinical Trials Program. Journal of Clinical Oncology, 32(27):2975-2982.

148. Lievre, A., Bachet, J.B., Boige, V., Cayre, A., Le Corre, D., Buc, E., Ychou, M., Bouche, O., Landi, B., Louvet, C., Andre, T., Bibeau, F., Diebold, M.D., Rougier, P., Ducreux, M., Tomasic, G., Emile, J.F., Penault-Llorca, F., Laurent-Puig, P. 2008. KRAS mutations as an independent prognostic factor in patients with advanced colorectal cancer treated with cetuximab. Journal of Clinical Oncology, 26(3):374-379.

149. Lievre, A., Bachet, J.B., Le Corre, D., Boige, V., Landi, B., Emile, J.F., Cote, J.F., Tomasic, G., Penna, C., Ducreux, M., Rougier, P., Penault-Llorca, F., Laurent-Puig, P. 2006. KRAS mutation status is predictive of response to cetuximab therapy in colorectal cancer. Cancer Research, 66: 3992-3995.

150. Locker, G.Y., Hamilton, S., Harris, J., Jessup, J.M., Kemeny, N., Macdonald, J.S., Somerfield, M.R., Hayes, D.F., Bast, R.C. 2006. ASCO 2006 Update of Recommendations for the Use of Tumor Markers in Gastrointestinal Cancer. Journal of Clinical Oncology, 24(33):5313-5327.

151. Lonneux, M., Reffad, A.M., Detry, R., Kartheuser, A., Gigot, J.F., Pauwels, S. 2002. FDG-PET improves the staging and selection of patients with recurrent colorectal cancer. European Journal of Nuclear Medicine and Molecular Imaging, 29(7):915-921.

152. López-Saavedra, A., Ramírez-Otero, M., Díaz-Chávez, J., Cáceres-Gutiérrez, R., Justo-Garrido, M., Andonegui, M.A., Mendoza, J., Downie-Ruíz, Á., Cortés-González, C., Reynoso, N., Castro-Hernández, C., Domínguez-Gómez, G., Santibáñez, M,. Fabián-Morales, E., Pruefer, F., 
Luna-Maldonado, F., González-Barrios, R., Herrera, L.A. 2016. MAD2 $\gamma$, a novel MAD2 isoform, reduces mitotic arrest and is associated with resistance in testicular germ cell tumors. Cell Cycle, 15(15):2066-2076.

153. Luijten, M.N.H., Lee, J.X.T., Crasta, K.C. 2018. Mutational game changer : Chromothripsis and its emerging relevance to cancer. Mutation Research, 777:29-51.

154. Ly, P., Cleveland, D.W. 2017. Rebuilding Chromosomes After Catastrophe: Emerging Mechanisms of Chromothripsis. Trends in Cell Biology, 27(12):917-930.

155. Lyass, S., Zamir, G., Matot, I., Goiten, D., Eid, A., Jurim, O. 2001. Combined colon and hepatic resection for synchronous colorectal liver metastases. Journal of Surgical Oncology, 78:17-21.

156. Ma, J., Zhao, J., Lu, J., Wang, P., Feng, H., Zong, Y., Ou, B., Zheng, M., Lu, A. 2016. Cadherin12 enhances proliferation in colorectal cancer cells and increases progression by promoting EMT. Tumour Biology, 37(7):9077-9088.

157. Mabro, M., Artru, P., Andre, T., Flesch, M., Maindrault-Goebel, F., Landi, B. 2006. A phase II study of FOLFIRI-3 (double infusion of irinotecan combined with LV5FU) after FOLFOX in advanced colorectal cancer patients. British Journal of Cancer, 94:1287-1292.

158. Macedo, L.T., da Costa Lima, A.B., Sasse, A.D. 2012. Addition of bevacizumab to first-line chemotherapy in advanced colorectal cancer: a systematic review and meta-analysis, with emphasis on chemotherapy subgroups. BMC Cancer, 12:89.

159. Magrangeas, F., Avet-Loiseau, H., Munshi, N.C., Minvielle, S. 2011. Chromothripsis identifies a rare and aggressive entity among newly diagnosed multiple myeloma patients. Blood, 118(3):675-678.

160. Maheswaran, S., Sequist, L.V., Nagrath, S., Ulkus, L., Brannigan, B., Collura, C.V., Inserra, E., Diederichs, S., Iafrate, A.J., Bell, D.W., Digumarthy, S., Muzikansky, A., Irimia, D., Settleman, J., Tompkins, R.G., Lynch, T.J., Toner, M., Haber, D.A. 2008. Detection of mutations in EGFR in circulating lung-cancer cells. New England Journal of Medicine, 359:366-377.

161. Mao, C., Yang, Z.Y., Hu, X.F., Chen, Q., Tang, J.L. 2011. PIK3CA exon 20 mutations as a potential biomarker for resistance to anti-EGFR monoclonal antibodies in KRAS wild-type metastatic colorectal cancer: a systematic review and meta-analysis. Annals of Oncology, 23(6):1518-1525.

162. Martin, R., Paty, P., Fong, Y., Grace, A., Cohen, A., DeMatteo, R., Jarnagin, W., Blumgart, L. 2003. Simultaneous liver and colorectal resections are safe for synchronous colorectal liver metastasis. Journall of the American College of Surgeons, 197:233-241.

163. Masi, G., Salvatore, L., Boni, L., Loupakis, F., Cremolini, C., Fornaro, L., Schirripa, M., Cupini, S., Barbara, C., Safina, V., Granetto, C., Fea, E., Antonuzzo, L., Boni, C., Allegrini, G., Chiara, S., Amoroso, D., Bonetti, A., Falcone, A., BEBYP Study Investigators.2015. Continuation or reintroduction of bevacizumab beyond progression to first-line therapy in metastatic colorectal cancer: final results of the randomized BEBYP trial. Annals of Oncology, 26(4):724-730.

164. Maughan, T.S., Adams, R.A., Smith, C.G., Meade, A.M., Seymour, M.T., Wilson, R.H., Idziaszczyk, S., Harris, R., Fisher, D., Kenny, S.L., Kay, E., Mitchell, J.K., Madi, A., Jasani, B., James, M.D., Bridgewater, J., Kennedy, M.J., Claes, B., Lambrechts, D., Kaplan, R., Cheadle, J.P. 2011. Addition of cetuximab to oxaliplatin-based first-line combination chemotherapy for treatment of advanced colorectal cancer: results of the randomised phase 3 MRC COIN trial. Lancet, 377:2103-2114.

165. Mayer, R.J., Van Cutsem, E., Falcone, A., Yoshino, T., Garcia-Carbonero, R., Mizunuma, N., Yamazaki, K., Shimada, Y., Tabernero, J., Komatsu, Y., Sobrero, A., Boucher, E., Peeters, M., Tran, B., Lenz, H.J., Zaniboni, A., Hochster, H., Cleary, J.M., Prenen, H., Benedetti, F., Mizuguchi, H., Makris, L., Ito, M., Ohtsu, A., RECOURSE Study Group. 2015. Randomized trial of TAS-102 for refractory metastatic colorectal cancer. New England Journal of Medicine, 372(20):1909-1919. 
166. McBride, D.J., Orpana, A.K., Sotiriou, C., Joensuu, H., Stephens, P.J., Mudie, L.J., Hämäläinen, E., Stebbings, L.A., Andersson, ～L.C., Flanagan, A.M., Durbecq, V., Ignatiadis, M., Kallioniemi, O., Heckman, C.A., Alitalo, K., Edgren, H., Futreal, P.A., Stratton, M.R., Campbell, P.J. 2010. Use of cancer-specific genomic rearrangements to quantify disease burden in plasma from patients with solid tumors. Genes Chromosomes Cancer, 49:1062-1069.

167. Mekenkamp, J.M., Koopman, M., Teerenstra, S., van Krieken, J.H.J.M., Mol, L., Nagtegaal, I.D., Punt, C.J.A. 2010. Clinicopathological features and outcome in advanced colorectal cancer patients with synchronous $v s$ metachronous metastases. British Journal of Cancer, 103(2):159164.

168. Meric-Bernstam, F., Hurwitz, H., Raghav, K.P.S., McWilliams, R.R., Fakih, M., VanderWalde, A., Swanton, C., Kurzrock, R., Burris, H., Sweeney, C., Bose, R., Spigel, D.R., Beattie, M.S., Blotner, S., Stone, A., Schulze, K., Cuchelkar, V., Hainsworth, J. 2019. Pertuzumab plus trastuzumab for HER2-amplified metastatic colorectal cancer (MyPathway): an updated report from a multicentre, open-label, phase 2a, multiple basket study. Lancet Oncology, 20:518-530.

169. Mitry, E., Fields, A.L., Bleiberg, H., Labianca, R., Portier, G., Tu, D., Nitti, D., Torri, V., Elias, D., O'Callaghan, C., Langer, B., Martignoni, G., Bouché, O., Lazorthes, F., Van Cutsem, E., Bedenne, L., Moore, M.J., Rougier, P.J. 2008. Adjuvant chemotherapy after potentially curative resection of metastases from colorectal cancer: a pooled analysis of two randomized trials. Clinical Oncology, 20;26(30):4906-4911.

170. Moriwaki T., Fukuoka S., Masuishi T., Takashima A., Kumekawa Y., Kajiwara T., Yamazaki K., Esaki T., Makiyama A., Denda T., Hatachi Y., Suto T., Sugimoto N., Enomoto M., Ishikawa T., Kashiwada T., Oki E., Komatsu Y., Tsuji A., Tsuchihashi K., Sakai D., Ueno H., Tamura T., Yamashita K., Shimada Y. 2020. Prognostic scores for evaluating the survival benefit of regorafenib or trifluridine/tipiracil in patients with metastatic colorectal cancer: an exploratory analysis of the REGOTAS study. International Journal of Clinical Oncology, 25(4):614-621.

171. Moroni, M., Veronese, S., Benvenuti, S., Marrapese, G., Sartore-Bianchi, A., Di Nicolantonio, F., Gambacorta, M., Siena, S., Bardelli, A. 2005. Gene copy number for epidermal growth factor receptor (EGFR) and clinical response to antiEGFR treatment in colorectal cancer: a cohort study. Lancet Oncology, 6: 279-286.

172. Morrison, C.D., Liu, P., Woloszynska-Read, A., Zhang, J., Luo, W., Qin, M., Bshara, W., Conroy, J.M., Sabatini, L., Vedell, P., Xiong, D., Liu, S., Wang, J., Shen, H., Li, Y., Omilian, A.R., Hill, A., Head, K., Guru, K., Kunnev, D., Leach, R., Eng, K.H., Darlak, C., Hoeflich, C., Veeranki, S., Glenn, S., You, M., Pruitt, S.C., Johnson, C.S., Trump, D.L. 2014. Whole-genome sequencing identifies genomic heterogeneity at a nucleotide and chromosomal level in bladder cancer. Proceedings of the National Academy of Sciences of the United States of America, 111(6):E672-E681.

173. Nakamura, S., Suzuki, S., Konno, H. 1999. Resection of hepatic metastases of colorectal carcinoma: 20 years' experience. Journal of Hepatobiliary Pancreatic Surgery, 6(1):16-22.

174. National cancer institute. Cancer stat facts: colorectal cancer. https://seer.cancer.gov/statfacts/html/colorect.html

175. NCCN clinical practice guidelinesin Oncology. Colon Cancer. Version 4.2019- Nov 8, 2019. https://www.nccn.org/professionals/physician_gls/pdf/colon.pdf

176. Ng, E.K., Chong, W.W., Jin, H., Lam, E.K., Shin, V.Y., Yu, J., Poon ,T.C., Ng, S.S., Sung, J.J. 2009. Differential expression of microRNAs in plasma of patients with colorectal cancer: A potential marker for colorectal cancer screening. Gut, 58:1375-1381.

177. Nielsen, M., Moreau, H., Vasen, H.F., Hes, F.J. 2011. MUTYH-associated polyposis (MAP). Critical Reviews in Oncology and Hematology, 79:1-16.

178. Nikolaev, S.I., Sotiriou, S.K., Pateras, I.S., Santoni, F., Sougioultzis, S., Edgren, H., Almusa, H., Robyr, D., Guipponi, M., Saarela, J., Gorgoulis, V.G., Antonarakis, S.E., Halazonetis, T.D. 
2012. A single-nucleotide substitution mutator phenotype revealed by exome sequencing of human colon adenomas. Cancer Research, 72(23):6279-6289.

179. Nordlinger, B., Sorbye, H., Glimelius, B., Poston, G.J., Schlag, P.M., Rougier, P., Bechstein, W.O., Primrose, J.N., Walpole, E.T., Finch-Jones, M., Jaeck, D., Mirza, D., Parks, R.W., Collette, L., Praet, M., Bethe, U., Van Cutsem, E., Scheithauer, W., Gruenberger, T. 2008. Perioperative chemotherapy with FOLFOX4 and surgery versus surgery alone for resectable liver metastases from colorectal cancer (EORTC Intergroup trial 40983): a randomised controlled trial. Lancet, 371:1007-1016.

180. Nordlinger, B., Sorbye, H., Glimelius, B., Poston, G.J., Schlag, P.M., Rougier, P., Bechstein, W.O., Primrose, J.N., Walpole, E.T., Finch-Jones, M., Jaeck, D., Mirza, D., Parks, R.W., Collette, L., Praet, M., Bethe, U., Van Cutsem, E., Scheithauer, W., Gruenberger, T. 2008. Perioperative chemotherapy with FOLFOX4 and surgery versus surgery alone for resectable liver metastases from colorectal cancer (EORTC Intergroup trial 40983): a randomised controlled trial. Lancet, 22(371):1007-1016.

181. Nosho, K., Kawasaki, T., Ohnishi, M., Suemoto, Y., Kirkner, G.J., Zepf, D., Yan, L., Longtine, J.A., Fuchs, C.S., Ogino, S. 2008. PIK3CA mutation in colorectal cancer: relationship with genetic and epigenetic alterations. Neoplasia, 10:534-541.

182. Ogino, S., Nosho, K., Kirkner, G.J., Kawasaki, T., Meyerhardt, J.A., Loda, M., Giovannucci, E.L., Fuchs, C.S. 2009. CpG island methylator phenotype, microsatellite instability, BRAF mutation and clinical outcome in colon cancer. Gut, 58(1):90-96.

183. Okamura, R., Boichard, A., Kato, S., Sicklick, J. K., Bazhenova, L., Kurzrock, R. 2018. Analysis of NTRK Alterations in Pan-Cancer Adult and Pediatric Malignancies: Implications for NTRK-Targeted Therapeutics. JCO precision oncology, 2:1-20.

184. Ooi, A., Takehana, T., Li, X. Suzuki, S., Kunitomo, K., Iino, H., Fujii, H., Takeda, Y., Dobashi, Y. 2004. Protein overexpression and gene amplification of HER-2 and EGFR in colorectal cancers: an immunohistochemical and fluorescent in situ hybridization study. Modern Pathology, 17:895-904.

185. Overman, M.J., McDermott, R., Leach, J.L., Lonardi, S., Lenz, H.J., Morse, M.A., Desai, J., Hill, A., Axelson, M., Moss, R.A., Goldberg, M.V., Cao, Z.A., Ledeine, J.M., Maglinte, G.A., Kopetz, S., André, T. 2017.Nivolumab in patients with metastatic DNA mismatch repairdeficient or microsatellite instability- high colorectal cancer (CheckMate 142): an open-label, multicentre, phase 2 study. Lancet Oncology, 18:1182-1191.

186. Palles, C., Cazier, J.B., Howarth, K.M., Domingo, E., Jones, A.M., Broderick, P., Kemp, Z., Spain, S.L., Guarino, E., Salguero, I., Sherborne, A., Chubb, D., Carvajal-Carmona, L.G., Ma, Y., Kaur, K., Dobbins, S., Barclay, E., Gorman, M., Martin, L., Kovac, M.B., Humphray, S., CORGI Consortium., WGS500 Consortium, Lucassen, A., Holmes, C.C., Bentley, D., Donnelly, P., Taylor, J., Petridis, C., Roylance, R., Sawyer, E.J., Kerr, D.J., Clark, S., Grimes, J., Kearsey, S.E., Thomas, H.J., McVean, G., Houlston, R.S., Tomlinson, I. 2013. Germline mutations affecting the proofreading domains of POLE and POLD1 predispose to colorectal adenomas and carcinomas. Nature Genetics, 45(2):136-144.

187. Pantel, K., Brakenhoff, R.H., Brandt, B. 2008. Detection, clinical relevance and specific biological properties of disseminating tumour cells. Nature Reviews. Cancer, 8:329-340.

188. Patzold, L.A., Berzina, D., Daneberga, Z., Gardovskis, J., Miklaševičs, E. 2017. Detection of Allelic Variants of the POLE and POLDI Genes in Colorectal Cancer Patients. Balkan Journal of Medical Genetics, 20(2):83-88.

189. Pawlik, T.M., Scoggins, C.R., Zorzi, D., Abdalla, E.K., Andres, A., Eng, C., Curley, S.A., Loyer, E.M., Muratore, A., Mentha, G., Capussotti, L, and Vauthey J.N. 2005. Effect of surgical margin status on survival and site of recurrence after hepatic resection for colorectal metastases. Annals of Surgery, 241(5):715-722.

190. Peeters, M., Price, T.J., Cervantes, A., Sobrero, A.F., Ducreux, M., Hotko, Y. 2010. Randomized phase III study of panitumumab with fluorouracil, leucovorin, and irinotecan 
(FOLFIRI) compared with FOLFIRI alone as second-line treatment in patients with metastatic colorectal cancer. Journal of Clinical Oncology, 28:4706-4713.

191. Pellon-Cardenas, O., Sirihorachai, V.R., Warder, B.N., Kothari, O.A., Perekatt, A.O., Fokas, E.E., Fullem, R.L., Zhou, A., Thackray, J.K., Tran, H., Zhang, L., Xing, J., Verzi, M.P. 2017. Degree of Tissue Differentiation Dictates Susceptibility to BRAF-Driven Colorectal Cancer. Cell Report, 21(13):3833-3845.

192. Perez-Villamil, B., Romera-Lopez, A., Hernandez-Prieto, S., Lopez-Campos, G., Calles, A., Lopez-Asenjo, J.A., Sanz-Ortega, J., Fernandez-Perez, C., Sastre, J., Alfonso, R., Caldes, T., Martin-Sanchez, F., Diaz-Rubio, E. 2012. Colon cancer molecular subtypes identified by expression profiling and associated to stroma, mucinous type and different clinical behavior. BMC Cancer, 12:260.

193. Personeni, N., Fieuws, S., Piessevaux, H., De Hertogh, G., De Schutter, J., Biesmans, B., De Roock, W., Capoen, A., Debiec-Rychter, M., Van Laethem, J.L., Peeters, M., Humblet, Y., Van Cutsem, E. and Tejpar, S. 2008. Clinical usefulness of EGFR gene copy number as a predictive marker in colorectal cancer patients treated with cetuximab: a fluorescent in situ hybridization study. Clinical Cancer Research, 14:5869-5876.

194. Phelps, R.A., Chidester, S., Dehghanizadeh, S., Phelps, J., Sandoval, I.T., Rai, K., Broadbent, T., Sarkar, S., Burt, R.W., Jones, D.A. 2009. A two-step model for colon adenoma initiation and progression caused by APC loss. Cell, 137(4):623-634.

195. Phipps, A.I., Limburg, P.J., Baron, J.A., Burnett-Hartman, A.N., Weisenberger, D.J., Laird, P.W., Sinicrope, F.A., Rosty, C., Buchanan, D.D., Potter, J.D., Newcomb, P.A. 2015. Association between molecular subtypes of colorectal cancer and patient survival. Gastroenterology, 148(1):77-87.

196. Pinheiro, M., Pinto, C., Peixoto, A., Veiga, I., Lopes, P., Henrique, R., Baldaia, H., Carneiro, F., Seruca, R., Tomlinson, I., Kovac, M., Heinimann, K., Teixeira, M.R. 2015. Target gene mutational pattern in Lynch syndrome colorectal carcinomas according to tumour location and germline mutation. British Journal of Cancer, 113(4):686-692.

197. Prenen H, De Schutter J, Jacobs B, De Roock W, Biesmans B, Claes B, Lambrechts D, Van Cutsem E, Tejpar S. 2009. PIK3CA mutations are not a major determinant of resistance to the epidermal growth factor receptor inhibitor cetuximab in metastatic colorectal cancer. Clinical Cancer Research, 2009; 15:3184-3188.

198. Press, R.D., Love, Z., Tronnes, A.A., Yang, R., Tran, T., Mongoue-Tchokote, S., Mori, M., Mauro, M.J., Deininger, M.W., Druker, B.J. 2006. BCR-ABL mRNA levels at and after the time of a complete cytogenetic response (CCR) predict the duration of CCR in imatinib mesylate-treated patients with CML. Blood, 107:4250-4256.

199. Przybytkowski, E., Lenkiewicz, E., Barrett, M.T. 2014. Chromosome-breakage genomic instability and chromothripsis in breast cancer. BMC Genomics, 15(1):579.

200. Purcell, R.V., Visnovska, M., Biggs, P.J., Schmeier, S., Frizelle, F.A. 2017. Distinct gut microbiome patterns associate with consensus molecular subtypes of colorectal cancer. Scientific Reports, 7(1):11590.

201. Qiu, C., Bu, X., Jiang, Z. 2016. Protocadherin-10 acts as a tumor suppressor gene, and is frequently downregulated by promoter methylation in pancreatic cancer cells. Oncology Reports, 36(1):383-389.

202. Rad, R., Cadiñanos, J., Rad, L., Varela, I., Strong, A., Kriegl, L., Constantino-Casas, F., Eser, S., Hieber, M., Seidler, B., Price, S., Fraga, M.F., Calvanese, V., Hoffman, G., Ponstingl, H., Schneider, G., Yusa, K., Grove, C., Schmid, R.M., Wang, W., Vassiliou, G., Kirchner, T., McDermott, U., Liu, P., Saur, D., Bradley, A. 2013. A genetic progression model of Braf(V600E)-induced intestinal tumorigenesis reveals targets for therapeutic intervention. Cancer Cell, 24(1):15-29.

203. Ranpura, V., Hapani, S., Wu, S. 2011. Treatment-related mortality with bevacizumab in cancer patients: a meta-analysis. JAMA, 305(5):487-494. 
204. Reddy, S.K., Morse, M.A., Hurwitz, H.I., Bendell, J.C., Gan, T.J., Hill, S.E., Clary, B.M. 2008. Addition of bevacizumab to irinotecan- and oxaliplatin-based preoperative chemotherapy regimens does not increase morbidity after resection of colorectal liver metastases. Journal of American College of Surgeons, 206(1):96-106.

205. Resch, G., Schaberl-Moser, R., Kier, P., Kopetzky, G., Scheithauer, W., Sliwa, T., Greil, R., Nösslinger, T., Mayrbäurl, B., Thaler, J. 2011. Infusion reactions to the chimeric EGFR inhibitor cetuximab-change to the fully human anti-EGFR monoclonal antibody panitumumab is safe. Annals of Oncology, 22(2):486-487.

206. Richman, S. D. Seymour MT, Chambers P, Elliott F, Daly CL, Meade AM, Taylor G, Barrett JH, Quirke P. 2009. KRAS and BRAF mutations in advanced colorectal cancer are associated with poor prognosis but do not preclude benefit from oxaliplatin or irinotecan: results from the MRC FOCUS trial. Journal of Clinical Oncology, 27:5931-5937.

207. Roth, A.D., Tejpar, S., Delorenzi, M., Yan, P., Fiocca, R., Klingbiel, D., Dietrich, D., Biesmans, B., Bodoky, G., Barone, C., Aranda, E., Nordlinger, B., Cisar, L., Labianca, R., Cunningham, D., Van Cutsem, E., Bosman, F. 2010. Prognostic role of KRAS and BRAF in stage II and III resected colon cancer: results of the translational study on the PETACC-3, EORTC 40993, SAKK 60-00 trial. Journal of Clinical Oncology, 28: 466-474.

208. Rustin, G.J., van der Burg, M.E., Griffin, C.L., Guthrie, D., Lamont, A., Jayson, G.C., Kristensen, G., Mediola, C., Coens, C., Qian, W., Parmar, M.K., Swart, A.M., MRC OV05, EORTC 55955 investigators. 2010. Early versus delayed treatment of relapsed ovarian cancer (MRC OV05/EORTC 55955): a randomised trial. Lancet, 376(9747):1155-1163.

209. Sadanandam, A., Lyssiotis, C.A., Homicsko, K., Collisson, E.A., Gibb, W.J., Wullschleger, S., Ostos, L.C., Lannon, W.A., Grotzinger, C., Del Rio, M., Lhermitte, B., Olshen, A.B., Wiedenmann, B., Cantley, L.C., Gray, J.W., Hanahan, D.A. 2013. Colorectal cancer classification system that associates cellular phenotype and responses to therapy. Nature Medicine, 19(5):619-625.

210. Safaee Ardekani, G., Jafarnejad, S.M., Tan, L., Saeedi, A., Li, G. 2012. The prognostic value of BRAF mutation in colorectal cancer and melanoma: a systematic review and meta-analysis. PLoS One, 7(10):e47054.

211. Sakamoto, N., Feng, Y., Stolfi, C., Kurosu, Y., Green, M., Lin, J., Green, M.E., Sentani, K., Yasui, W., McMahon, M., Hardiman, K.M., Spence, J.R., Horita, N., Greenson, J.K., Kuick, R., Cho, K.R., Fearon, E.R. 2017. BRAFV600E cooperates with CDX2 inactivation to promote serrated colorectal tumorigenesis. eLife, 6:e20331.

212. Salazar, R., Roepman, P., Capella, G., Moreno, V., Simon, I., Dreezen, C., Lopez-Doriga, A., Santos, C., Marijnen, C., Westerga, J., Bruin, S., Kerr, D., Kuppen, P., van de Velde, C., Morreau, H., Van Velthuysen, L., Gals, A.M., Van't Veer, L.J., Tollenaar, R. 2011. Gene expression signature to improve prognosis prediction of stage II and III colorectal cancer. Journal of Clinical Oncology, 29(1):17-24.

213. Salem, M.E., Weinberg, B.A., Xiu, J., El-Deiry, W.S., Hwang, J.J., Gatalica, Z., Philip, P.A., Shields, A.F., Lenz, H.J., Marshall, J.L. 2017. Comparative molecular analyses of left-sided colon, right-sided colon, and rectal cancers. Oncotarget, 8(49):86356-86368.

214. Saltz, L.B., Clarke, S., Díaz-Rubio, E., Scheithauer, W., Figer, A., Wong, R., Koski, S., Lichinitser, M., Yang, T.S., Rivera, F., Couture, F., Sirzén, F., Cassidy, J. 2008. Bevacizumab in combination with oxaliplatin-based chemotherapy as first-line therapy in metastatic colorectal cancer: a randomized phase III study. Journal of Clinical Oncology,26(12):20132019.

215. Saltz, L.B., Cox, J.V., Blanke, C., Rosen, L.S., Fehrenbacher, L., Moore, M.J., Maroun, J.A., Ackland, S.P., Locker, P.K., Pirotta, N., Elfring, G.L., Miller, L.L. 2000. Irinotecan plus fluorouracil and leucovorin for metastatic colorectal cancer. Irinotecan Study Group. New England Journal of Medicine, 343:905-914. 
216. Salvatore, L., Niger, M., Bellu, L., Tamburini, E., Garcia-Alfonso, P., Amellal, N., Delmas, A.S., Wahba, M., Prager, G. 2016. Compassionate use program for trifluridine/tipiracil (TAS102) in metastatic colorectal cancer: A real-life overview. Annals of Oncology, 27(6s):512.

217. Sartore-Bianchi, A., Martini, M., Molinari, F., Veronese, S., Nichelatti, M., Artale, S., Di Nicolantonio, F., Saletti, P., De Dosso, S., Mazzucchelli, L., Frattini, M., Siena, S., Bardelli, A. 2009. PIK3CA mutations in colorectal cancer are associated with clinical resistance to EGFRtargeted monoclonal antibodies. Cancer Research, 69:1851-1857.

218. Sartore-Bianchi, A., Moroni, M., Veronese, S., Carnaghi, C., Bajetta, E., Luppi, G., Sobrero, A., Barone, C., Cascinu, S., Colucci, G., Cortesi, E., Nichelatti, M., Gambacorta, M. and Siena, S. 2007. Epidermal growth factor receptor gene copy number and clinical outcome of metastatic colorectal cancer treated with panitumumab. Journal of Clinical Oncology, 25:3238-3245.

219. Sartore-Bianchi, A., Trusolino, L., Martino, C., Bencardino, K., Lonardi, S., Bergamo, F., Zagonel, V., Leone, F., Depetris, I., Martinelli, E., Troiani, T., Ciardiello, F., Racca, P., Bertotti, A., Siravegna, G., Torri, V., Amatu, A., Ghezzi, S., Marrapese, G., Palmeri, L., Valtorta, E., Cassingena, A., Lauricella, C., Vanzulli, A., Regge, D., Veronese, S., Comoglio, P.M., Bardelli, A., Marsoni, S., Siena, S. 2016. Dual-targeted therapy with trastuzumab and lapatinib in treatment-refractory, KRAS codon 12/13 wild-type, HER2positive metastatic colorectal cancer (HERACLES): a proof-of-concept, multicentre, openlabel, phase 2 trial. Lancet Oncology, 17:738-746.

220. Scappaticci, F.A., Fehrenbacher, L., Cartwright, T., Hainsworth, J.D., Heim, W., Berlin, J., Kabbinavar, F., Novotny, W., Sarkar, S., Hurwitz, H. 2005. Surgical wound healing complications in metastatic colorectal cancer patients treated with bevacizumab. Journal of Surgical Oncology, 91(3):173-180.

221. Scarpati, G.D.V., Carlomagno, C., Marchini, S., Ubezio, P., Falcetta, F., D'Incalci, M., De Placido, S., Sabbatino, F., Fusciello, C., Pepe, S. 2011. A specific miRNA signature correlates with complete pathological response to neoadjuvant chemoradiotherapy in locally advanced rectal cancer. Journal of Clinical Oncology, 29: abstr 3610.

222. Schetter, A.J., Leung, S.Y., Sohn, J.J., Zanetti, K.A., Bowman, E.D., Yanaihara, N., Yuen, S.T., Chan, T.L., Kwong, D.L., Au, G.K., Liu, C.G., Calin, G.A., Croce, C.M., Harris, C.C. 2008. MicroRNA expression profiles associated with prognosis and therapeutic outcome in colon adenocarcinoma. JAMA, 299:425-436.

223. Schlag, P., Hohenberger, P., Herfarth, C. 1990. Resection of liver metastases in colorectal cancer-competitive analysis of treatment results in synchronous versus metachronous metastases. European Journal of Surgical Oncology, 16:360-365.

224. Schmoll, H.J., Cunningham, D., Sobrero, A., Karapetis, C.S., Rougier, P., Koski, S.L. 2010. mFOLFOX6 + cediranib vs mFOLFOX6 + bevacizumab in previously untreated metastatic colorectal cancer (mCRC): a randomized, double-blind, phase II/III study (HORIZON III). Annals of Oncology, 21(8): viii188.

225. Schou, J.V., Andersen, K.K., Jensen, B.V., Nielsen, D.L., Pfeiffer, P., Høgdall, E.V., Yilmaz, M., Kruhoffer, M., Johansen, J.S. 2011. Prediction of survival in patients with metastatic colorectal cancer treated with third-line cetuximab and irinotecan through changes in microRNA expression in whole blood during treatment. Journal of Clinical Oncology, 29:abstr 3532 .

226. Seymour, M.T., Maughan, T.S., Ledermann, J.A., Topham, C., James, R., Gwyther, S.J., Smith, D.B., Shepherd, S., Maraveyas, A., Ferry, D.R., Meade, A.M., Thompson, L., Griffiths, G.O., Parmar, M.K., Stephens, R.J., FOCUS Trial Investigators; National Cancer Research Institute Colorectal Clinical Studies Group. 2007. Different strategies of sequential and combination chemotherapy for patients with poor-prognosis advanced colorectal cancer (MRC FOCUS): A randomised controlled trial. Lancet, 370:143-152.

227. Shen, L., Yang, M., Lin, Q., Zhang, Z., Zhu, B., Miao, C. 2016. COL11A1 is overexpressed in recurrent non-small cell lung cancer and promotes cell proliferation, migration, invasion and drug resistance. Oncology Reports, 36(2):877-885. 
228. Shia, J., Klimstra, D.S., Li, A.R., Qin, J., Saltz, L., Teruya-Feldstein, J., Akram, M., Chung, K.Y., Yao, D., Paty, P.B., Gerald, W., Chen, B. 2005. Epidermal growth factor receptor expression and gene amplification in colorectal carcinoma: an immunohistochemical and chromogenic in situ hybridization study. Modern Pathology, 18:1350-1356.

229. Shirota, Y., Stoehlmacher, J., Brabender, J., Xiong, Y.P., Uetake, H., Danenberg, K.D., Groshen, S., Tsao-Wei, D.D., Danenberg, P.V., Lenz, H.J. 2001. ERCC1 and thymidylate synthase mRNA levels predict survival for colorectal cancer patients receiving combination oxaliplatin and fluorouracil chemotherapy. Journal of Clinical Oncology, 19:4298-4304.

230. Sinicrope, F.A., Shi, Q., Smyrk, T.C., Thibodeau, S.N., Dienstmann, R., Guinney, J., Bot, B.M., Tejpar, S., Delorenzi, M., Goldberg, R.M., Mahoney, M., Sargent, D.J., Alberts, S.R. 2015. Molecular markers identify subtypes of stage III colon cancer associated with patient outcomes. Gastroenterology, 148(1):88-99.

231. Slimību kontroles un profilakses centrs, 2017. https://www.spkc.gov.lv/lv/statistika-unpetijumi/statistika/veselibas-aprupes-statistika.

232. Smith, D.I., Zhu, Y., McAvoy, S., Kuhn, R. 2006. Common fragile sites, extremely large genes, neural development and cancer. Cancer Letters, 232(1):48-57.

233. Sobrero A, Ackland S, Clarke S, Perez-Carrión R, Chiara S, Gapski J, Mainwaring P, Langer B, Young S; AVIRI Trial investigators. 2009. Phase IV study of bevacizumab in combination with infusional fluorouracil, leucovorin and irinotecan (FOLFIRI) in first-line metastatic colorectal cancer. Oncology, 77(2):113-119.

234. Soda, M., Choi, Y.L., Enomoto, M., Takada, S., Yamashita, Y., Ishikawa, S., Fujiwara, S., Watanabe, H., Kurashina, K., Hatanaka, H., Bando, M., Ohno, S., Ishikawa, Y., Aburatani, H., Niki, T., Sohara, Y., Sugiyama, Y., Mano, H. 2007. Identification of the transforming EML4ALK fusion gene in non-small-cell lung cancer. Nature, 448:561-566.

235. Sonuga-Barke, E., Lasky-Su, J., Neale, B., Oades, R., Chen, W., Franke, B., Buitelaar, J., Banaschewski, T., Ebstein, R., Gill, M., Anney, R., Miranda, A., Mulas, F., Roeyers, H., Rothenberger, A., Sergeant, J., Steinhausen, H.C., Thompson, M., Asherson, P., Faraone, S.V. 2000. Does parental expressed emotion moderate genetic effects in ADHD? An exploration using a genome wide association scan. American journal of medical genetics, 147B:1359-1368.

236. Sorbye, H., Dahl, O. 2003. Carcinoembryonic antigen surge in metastatic colorectal cancer patients responding to oxaliplatin combination chemotherapy: Implications for tumor marker monitoring and guidelines. Journal of Clinical Oncology, 21:4466-4467.

237. Sorbye, H., Dahl, O. 2004. Transient CEA increase at start of oxaliplatin combination therapy for metastatic colorectal cancer. Acta Oncologica, 43:495-498.

238. Sorich, M.J., Wiese, M.D., Rowland, A., Kichenadasse, G., McKinnon, R.A., Karapetis, C.S. 2015. Extended RAS mutations and anti-EGFR monoclonal antibody survival benefit in metastatic colorectal cancer: a meta-analysis of randomized, controlled trials. Annals of Oncology, 26(1):13-21.

239. Sottoriva, A., Kang, H., Ma, Z., Graham, T.A., Salomon, M.P., Zhao, J., Marjoram, P., Siegmund, K., Press, M.F., Shibata, D., Curtis, C. 2015. A Big Bang model of human colorectal tumor growth. Nature Genetics, 47(3):209-216.

240. Souglakos, J., Androulakis, N., Syrigos, K., Polyzos, A., Ziras, N., Athanasiadis, A., Kakolyris, S., Tsousis, S., Kouroussis, Ch., Vamvakas, L., Kalykaki, A., Samonis, G., Mavroudis, D., Georgoulias, V. 2006. FOLFOXIRI (folinic acid, 5-fluorouracil, oxaliplatin and irinotecan) vs FOLFIRI (folinic acid, 5-fluorouracil and irinotecan) as first-line treatment in metastatic colorectal cancer (MCC): a multicentre randomised phase III trial from the Hellenic Oncology Research Group (HORG). British Journal of Cancer, 27;94(6):798-805.

241. Souglakos, J., Philips, J., Wang, R., Marwah, S., Silver, M., Tzardi, M., Silver, J., Ogino, S., Hooshmand, S., Kwak, E., Freed, E., Meyerhardt, J.A., Saridaki, Z., Georgoulias, V., Finkelstein, D., Fuchs, C.S., Kulke, M.H., Shivdasani, R.A. 2009. Prognostic and predictive 
value of common mutations for treatment response and survival in patients with metastatic colorectal cancer. British Journal of Cancer, 2009;101:465-472.

242. Stephens, P.J., Greenman, C.D., Fu, B., Yang, F., Bignell, G.R., Mudie, L.J., Pleasance, E.D., Lau, K.W., Beare, D., Stebbings, L.A., McLaren, S., Lin, M.L., McBride, D.J., Varela, I., Nik-Zainal, S., Leroy, C., Jia, M., Menzies, A., Butler, A.P., Teague, J.W., Quail, M.A., Burton, J., Swerdlow, H., Carter, N.P., Morsberger, L.A., Iacobuzio-Donahue, C., Follows, G.A., Green, A.R., Flanagan, A.M., Stratton, M.R., Futreal, P.A., Campbell, P.J. 2011. Massive Genomic Rearrangement Acquired in a Single Catastrophic Event during Cancer Development. Cell, 144(1):27-40.

243. Stintzing, S., Tejpar, S., Gibbs, P., Thiebach, L., Lenz, H.J. 2017. Understanding the role of primary tumour localisation in colorectal cancer treatment and outcomes. European Journal of Cancer, 84:69-80.

244. Sun, C., Huo, D., Southard, C., Nemesure, B., Hennis, A., Cristina Leske, M., Wu, S.Y., Witonsky, D.B., Olopade, O.I., Di Rienzo, A. 2011. A signature of balancing selection in the region upstream to the human UGT2B4 gene and implications for breast cancer risk. Human Genetics, 130(6):767-775.

245. Sun, M., Srikantan, V., Ma, L., Li, J., Zhang, W., Petrovics, G., Makarem, M., Strovel, J.W., Horrigan, S.G., Augustus, M., Sesterhenn, I.A., Moul, J.W., Chandrasekharappa, S., Zou, Z., Srivastava, S. 2006. Characterization of frequently deleted 6q locus in prostate cancer. DNA and Cell Biology, 25(11):597-607.

246. Tabernero, J., Yoshino, T., Cohn, A.L., Obermannova, R., Bodoky, G., Garcia-Carbonero, R., Ciuleanu, T.E., Portnoy, D.C., Van Cutsem, E., Grothey, A., Prausová, J., Garcia-Alfonso, P., Yamazaki, K., Clingan, P.R., Lonardi, S., Kim, T.W., Simms, L., Chang, S.C., Nasroulah, F. RAISE Study Investigators. 2015. Ramucirumab versus placebo in combination with secondline FOLFIRI in patients with metastatic colorectal carcinoma that progressed during or after first-line therapy with bevacizumab, oxaliplatin, and a fluoropyrimidine (RAISE): a randomised, double-blind, multicentre, phase 3 study. Lancet Oncology, 16:499-508.

247. Takezawa, K., Okamoto, I., Yonesaka, K., Hatashita, E., Yamada, Y., Fukuoka, M., Nakagawa, K. 2009. Sorafenib inhibits non-small cell lung cancer cell growth by targeting B-RAF in KRAS wild-type cells and C-RAF in KRAS mutant cells. Cancer Research, 69:6515-6521.

248. Tebbutt, N.C., Wilson, K., Gebski, V.J., Cummins, M.M., Zannino, D., van Hazel, G.A. 2010. Capecitabine, bevacizumab, and mitomycin in first-line treatment of metastatic colorectal cancer: results of the Australasian Gastrointestinal Trials Group Randomized Phase III MAX Study. Journal of Clinical Oncology, 28:3191-3198.

249. Teijeira, L., Viúdez, A., Arrazubi, V., Verdun, J., Uriz, M.J., Antelo, M.L., Tarifa, A., Zazpe, C. and Vera, R. 2011. Evolution of circulating tumor cells (CTCs) during neoadjuvant treatment and radical surgery in patients (pts) with liver-only metastases of colorectal cancer (L-CRC). Journal of Clinical Oncology, 29(15),suppl 2011:e14146.

250. Testa, U., Pelosi, E., Castelli, G. 2018. Colorectal cancer: genetic abnormalities, tumor progression, tumor heterogeneity, clonal evolution and tumor-initiating cells. Medical Sciences, 6(2):31.

251. Tol, J., Koopman, M., Cats, A., Rodenburg, C.J., Creemers, G.J., Schrama, J.G., Erdkamp, F.L., Vos, A.H., van Groeningen, C.J., Sinnige, H.A., Richel, D.J., Voest, E.E., Dijkstra, J.R., VinkBörger, M.E., Antonini, N.F., Mol, L., van Krieken, J.H., Dalesio, O., Punt, C.J. 2009. Chemotherapy, bevacizumab, and cetuximab in metastatic colorectal cancer. New England Journal of Medicine, 360(6):563-572.

252. Tomlins, S.A., Laxman, B., Dhanasekaran, S.M., Helgeson, B.E., Cao, X., Morris, D.S., Menon, A., Jing, X., Cao, Q., Han, B., Yu, J., Wang, L., Montie, J.E., Rubin, M.A., Pienta, K.J., Roulston, D., Shah, R.B., Varambally, S., Mehra, R., Chinnaiyan, A.M. 2007. Distinct classes of chromosomal rearrangements create oncogenic ETS gene fusions in prostate cancer. Nature, 448:595-599. 
253. Tomlins, S.A., Rhodes, D.R., Perner, S., Dhanasekaran, S.M., Mehra, R., Sun, X.W., Varambally, S., Cao, X., Tchinda, J., Kuefer, R., Lee, C., Montie, J.E., Shah, R.B., Pienta, K.J., Rubin, M.A., Chinnaiyan, A.M. 2005. Recurrent fusion of TMPRSS2 and ETS transcription factor genes in prostate cancer. Science, 310:644-648.

254. Tournigand, C., Andre, T., Achille, E., Lledo, G., Flesh, M., Mery-Mignard, D., Quinaux, E., Couteau, C., Buyse, M., Ganem, G., Landi, B., Colin, P., Louvet, C., de Gramont, A. 2004. FOLFIRI followed by FOLFOX6 or the reverse sequence in advanced colorectal cancer: a randomized GERCOR study. Journal of Clinical Oncology, 22(2):229-237.

255. Tsai, M.S., Su, Y.H., Ho, M.C., Liang, J.T., Chen, T.P., Lai, H.S. and Lee, P.H. 2007. Clinicopathological Features and Prognosis in Resectable Synchronous and Metachronous Colorectal Liver Metastasis. Annals of Surgical Oncology, 14(2):786-794.

256. Tveit, K., Guren, T., Glimelius, B., Pfeiffer, P., Sorbye, H., Pyrhonen, S., Kure, E., Ikdahl, T., Skovlund, E., Christoffersen, T. 2011. Randomized phase III study of 5fluorouracil/folinate/oxaliplatin given continuously or intermittently with or without cetuximab, as first-line treatment of metastatic colorectal cancer: The NORDIC VII study (NCT00145314), by the Nordic Colorectal Cancer Biomodulation Group. Journal of Clinical Oncology, 29 (4s): abstr 365 .

257. United states cancer statistics. Data visualisation. 2016. https://gis.cdc.gov/Cancer/USCS/DataViz.html

258. Van Cutsem, E, Lang, I., Folprecht, G., Nowacki, M., Barone, C., Shchepotin, I., Maurel, J., Cunningham, D., Celik, I. and Kohne, C. 2010. Cetuximab plus FOLFIRI: Final data from the CRYSTAL study on the association of KRAS and BRAF biomarker status with treatment outcome. Journal of Clinical Oncology, 2010 ASCO Annual Meeting Proceedings (PostMeeting Edition), 28(15): 3570.

259. Van Cutsem, E., Cervantes, A., Adam, R., Sobrero, A., Van Krieken, J.H., Aderka, D., Aranda Aguilar E., Bardelli, A., Benson, A., Bodoky, G., Ciardiello, F., D'Hoore, A., Diaz-Rubio, E., Douillard, J.Y., Ducreux, M., Falcone, A., Grothey, A., Gruenberger, T., Haustermans, K., Heinemann, V., Hoff, P., Köhne, C.H., Labianca, R., Laurent-Puig, P., Ma, B., Maughan, T., Muro, K., Normanno, N., Österlund, P., Oyen, W.J.G., Papamichael, D., Pentheroudakis, G., Pfeiffer, P., Price,T.J., Punt, C., Ricke, J., Roth, A., Salazar, R., Scheithauer, W., Schmoll, H.J., Tabernero, J., Taïeb, J., Tejpar, S., Wasan, H., Yoshino, T., Zaanan, A., Arnold, D. 2016. ESMO consensus guidelines for the management of patients with metastatic colorectal cancer. Annals of Oncology, 27(8):1386-1422.

260. Van Cutsem, E., Huijberts, S., Grothey, A., Yaeger, R., Cuyle, P.J., Elez, E., Fakih, M., Montagut, C., Peeters, M., Yoshino, T., Wasan, H., Desai, J., Ciardiello, F., Gollerkeri, A., Christy-Bittel, J., Maharry, K., Sandor, V., Schellens, J.H.M., Kopetz, S., Tabernero, J. 2019. Binimetinib, Encorafenib, and Cetuximab Triplet Therapy for Patients With BRAF V600E-Mutant Metastatic Colorectal Cancer: Safety Lead-In Results From the Phase III BEACON Colorectal Cancer Study. Journal of Clinical Oncology, 37:1460-1469.

261. Van Cutsem, E., Köhne, C.H., Hitre, E., Zaluski, J., Chang Chien, C.R., Makhson, A., D'Haens, G., Pintér, T., Lim, R., Bodoky, G., Roh, J.K., Folprecht, G., Ruff, P., Stroh, C., Tejpar, S., Schlichting, M., Nippgen, J., Rougier, P. 2009. Cetuximab and chemotherapy as initial treatment for metastatic colorectal cancer. New England Journal of Medicine, 360(14):14081417.

262. Van Cutsem, E., Köhne, C.H., Láng, I., Folprecht, G., Nowacki, M.P., Cascinu, S., Shchepotin, I., Maurel, J., Cunningham, D., Tejpar, S., Schlichting, M., Zubel, A., Celik, I., Rougier, P., Ciardiello, F. 2011. Cetuximab plus irinotecan, fluorouracil, and leucovorin as first-line treatment for metastatic colorectal cancer: updated analysis of overall survival according to tumor KRAS and BRAF mutation status. Journal of Clinical Oncology, 29(15):2011-2019.

263. Van Cutsem, E., Lang, I., Folprecht, G. 2010. Cetuximab plus FOLFIRI in the treatment of metastatic colorectal cancer (mCRC): the influence of KRAS and BRAF biomarkers on 
outcome: updated data from the CRYSTAL trial. Program and abstracts of the 2010 Gastrointestinal Cancers Symposium: Abstr 281.

264. Van Cutsem, E., Lenz, H.J., Köhne, C.H., Heinemann, V., Tejpar, S., Melezínek, I., Beier, F., Stroh, C., Rougier, P., van Krieken, J.H., Ciardiello, F. 2014. Fluorouracil, leucovorin, and irinotecan plus cetuximab treatment and $R A S$ mutations in colorectal cancer. Journal of Clinical Oncology, 33:692-700.

265. Van Cutsem, E., Nordlinger, B., Adam, R. 2006. Towards a pan-European consensus on the treatment of patients with colorectal liver metastases. European Journal of Cancer, 42: 22122221.

266. Van Cutsem, E., Peeters, M., Siena, S., Humblet, Y., Hendlisz, A., Neyns, B. 2007. Open-label phase III trial of panitumumab plus best supportive care compared with best supportive care alone in patients with chemotherapy-refractory metastatic colorectal cancer. Journal of Clinical Oncology, 25:1658-1664.

267. Van Cutsem, E., Tabernero, J., Lakomy, R., Prausova, J., Ruff, P., Van Hazel, P. 2011. Intravenous (IV) aflibercept versus placebo in combination with irinotecan/5-FU (FOLFIRI) for second-line treatment of metastatic colorectal cancer (MCRC): results of a multinational phase III trial (EFC10262- VELOUR). Annals of Oncology, 22(5):v10-v18.

268. van den Broek, E., Dijkstra, M.J.J., Krijgsman, O., Sie, D., Haan, J.C. 2015. High Prevalence and Clinical Relevance of Genes Affected by Chromosomal Breaks in Colorectal Cancer. PLoS ONE, 10(9):e0138141.

269. van Poppelen, N.M., Yavuzyigitoglu, S., Smit, K.N., Vaarwater, J., Eussen, B., Brands, T., Paridaens, D., Kiliç, E., de Klein, A. 2018. Chromosomal rearrangements in uveal melanoma: Chromothripsis. Genes, Chromosomes and Cancer, 57(9):452-458.

270. van Vledder, M.G., de Jong, M.C. Pawlik, T.M. Schulick, R.D., Diaz, L.A., Choti M.A. 2010. Disappearing Colorectal Liver Metastases after Chemotherapy: Should we be Concerned? Journal of Gastrointestinal Surgery, 14:1691-1700.

271. Vauthey, J.N., Pawlik, T.M., Ribero, D., Wu, T.T., Zorzi, D., Hoff, P.M., Xiong, H.Q., Eng, C., Lauwers, G.Y., Mino-Kenudson, M., Risio, M., Muratore, A., Capussotti, L., Curley, S.A., Abdalla, E.K. 2006. Chemotherapy regimen predicts steatohepatitis and an increase in 90-day mortality after surgery for hepatic colorectal metastases. Journal of Clinical Oncology, 24(13):2065-2072.

272. Venkatachalam, R., Verwiel, E.T., Kamping, E.J., Hoenselaar, E., Görgens, H., Schackert, H.K., van Krieken, J.H., Ligtenberg, M.J., Hoogerbrugge, N., van Kessel, A.G., Kuiper, R.P. 2011. Identification of candidate predisposing copy number variants in familial and early-onset colorectal cancer patients. International Journal of Cancer, 129(7):1635-1642.

273. Vermeulen, J., Ballet, S., Oberlin, O., Peter, M., Pierron, G., Longavenne, E., Laurence, V., Kanold, J., Chastagner, P., Lejars, O., Blay, J.Y., Marec-Berard, P., Michon, J., Delattre, O., Schleiermacher, G. 2006. Incidence and prognostic value of tumour cells detected by RT-PCR in peripheral blood stem cell collections from patients with Ewing tumour. British Journal of Cancer, 95:1326-1333.

274. Vogelstein, B., Papadopoulos, N., Velculescu, V.E., Zhou, S., Diaz, L.A., Kinzler, K.W. 2013. Cancer genome landscapes. Science, 339:1546-1558.

275. Walther, A., Johnstone, E., Swanton, C., Midgley, R., Tomlinson, I., Kerr, D. 2009. Genetic prognostic and predictive markers in colorectal cancer. Nature Revievs. Cancer, 9(7):489-499.

276. Wang, F., Bai, L., Liu, T.S., Yu, Y.Y., He, M.M., Liu, K.Y., Luo, H.Y., Zhang, D.S., Jin, Y., Wang, F.H., Wang, Z.Q., Wang, D.S., Qiu, M.Z., Ren, C., Li, Y.H., Xu, R.H. 2015. Right-sided colon cancer and left-sided colorectal cancers respond differently to cetuximab. Chinese Journal of Cancer, 34(9):384-393.

277. Weren, R.D., Ligtenberg, M.J., Kets, C.M., de Voer, R.M., Verwiel, E.T., Spruijt, L., van ZelstStams, W.A., Jongmans, M.C., Gilissen, C., Hehir-Kwa, J.Y., Hoischen, A., Shendure, J., 
Boyle, E.A., Kamping, E.J., Nagtegaal, I.D., Tops, B.B., Nagengast, F.M., Geurts van Kessel, A., van Krieken, J.H., Kuiper, R.P., Hoogerbrugge, N. 2015. A germline homozygous mutation in the base-excision repair gene NTHL1 causes adenomatous polyposis and colorectal cancer. Nature Genetics, 47(6):668-671.

278. Wood, L.D., Parsons, D.W., Jones, S., Lin, J., Sjöblom, T., Leary, R.J., Shen, D., Boca, S.M., Barber, T., Ptak, J., Silliman, N., Szabo, S., Dezso, Z., Ustyanksky, V., Nikolskaya, T., Nikolsky, Y., Karchin, R., Wilson, P.A., Kaminker, J.S., Zhang, Z., Croshaw, R., Willis, J., Dawson, D., Shipitsin, M., Willson, J.K., Sukumar, S., Polyak, K., Park, B.H., Pethiyagoda, C.L., Pant, P.V., Ballinger, D.G., Sparks, A.B., Hartigan, J., Smith, D.R., Suh, E., Papadopoulos, N., Buckhaults, P., Markowitz, S.D., Parmigiani, G., Kinzler, K.W., Velculescu, V.E., Vogelstein, B. 2007. The genomic landscapes of human breast and colorectal cancers. Science, 318:1108-1113.

279. Yaeger, R., Chatila, W.K., Lipsyc, M.D., Hechtman, J.F., Cercek, A., Sanchez-Vega, F., Jayakumaran, G., Middha, S., Zehir, A., Donoghue, M.T.A., You, D., Viale, A., Kemeny, N., Segal, N.H., Stadler, Z.K., Varghese, A.M., Kundra, R., Gao, J., Syed, A., Hyman, D.M., Vakiani, E., Rosen, N., Taylor, B.S., Ladanyi, M., Berger, M.F., Solit, D.B., Shia, J., Saltz, L., Schultz, N. 2018. Clinical Sequencing Defines the Genomic Landscape of Metastatic Colorectal Cancer. Cancer Cell, 33(1):125-136.

280. Yamamoto, K., Gandin, V., Sasaki, M., McCracken, S., Li, W., Silvester, J.L., Elia, A.J., Wang, F., Wakutani, Y., Alexandrova, R., Oo, Y.D., Mullen, P.J., Inoue, S., Itsumi, M., Lapin, V., Haight, J., Wakeham, A., Shahinian, A., Ikura, M., Topisirovic, I., Sonenberg, N., Mak, T.W. 2014. Largen: a molecular regulator of mammalian cell size control. Molecular Cell, 53(6):904-915.

281. Yamauchi, M., Morikawa, T., Kuchiba, A., Imamura, Y., Qian, Z.R., Nishihara, R., Liao, X., Waldron, L., Hoshida, Y., Huttenhower, C., Chan, A.T., Giovannucci, E., Fuchs, C., Ogino, S. 2012. Assessment of colorectal cancer molecular features along bowel subsites challenges the conception of distinct dichotomy of proximal versus distal colorectum. Gut, 61(6):847-854.

282. Yang, S., Yan, H.L., Tao, Q.F., Yuan, S.X., Tang, G.N., Yang, Y., Wang, L.L., Zhang, Y.L., Sun, S.H., Zhou, W.P. 2014. Low CADM2 expression predicts high recurrence risk of hepatocellular carcinoma patients after hepatectomy. Journal of Cancer Research and Clinical Oncology, 140(1):109-116.

283. Yang, X.W., Shen, G.Z., Cao, L.Q., Jiang, X.F., Peng, H.P., Shen, G., Chen, D., Xue, P.L.Q. 2014. MicroRNA-1269 promotes proliferation in human hepatocellular carcinoma via downregulation of FOXO1. BMC Cancer, 14:909.

284. Ychou, M., Bouche, O., Thézenas, S., Francois, E., Adenis, A., Bennouna, J., Taïeb, J., Desseigne, F., Seitz, J., Conroy, T., Galais, M., Crapez, E., Poujol, S., Bibeau, F., Laurent-Puig, P., Samalin E. 2011. Final results of a multicenter phase II trial assessing sorafenib (S) in combination with irinotecan (i) as second- or later-line treatment in metastatic colorectal cancer (mCRC) patients (pts) with KRAS-mutated tumors (mt; NEXIRI). Clinical Oncology, 29:abstr e14002.

285. Yoo, P.S., Lopez-Soler, R.I., Longo, W.E., Cha, C.H. 2006. Liver Resection for Metastatic Colorectal Cancer in the Age of Neoadjuvant Chemotherapy and Bevacizumab. Clinical Colorectal Cancer, 6(3): 202-207.

286. Yoshino, T., Mizunuma, N., Yamazaki, K., Nishina, T., Komatsu, Y., Baba, H., Tsuji, A., Yamaguchi, K., Muro, K., Sugimoto, N., Tsuji, Y., Moriwaki, T., Esaki, T., Hamada, C., Tanase, T., Ohtsu, A. 2012. TAS-102 monotherapy for pretreated metastatic colorectal cancer: a double-blind, randomized, placebo-controlled phase 2 trial. Lancet Oncology, 13(10):993-1001.

287. Yu, J., Wu, W.K., Li, X., He, J., Li, X.X., Ng, S.S., Yu, C., Gao, Z., Yang, J., Li, M., Wang, Q., Liang, Q., Pan, Y., Tong, J.H., To, K.F., Wong, N., Zhang, N., Chen, J., Lu, Y., Lai, P.B., Chan, F.K., Li, Y., Kung, H.F., Yang, H., Wang, J., Sung, J.J. 2015. Novel recurrently mutated genes and a prognostic mutation signature in colorectal cancer. Gut, 64(4):636-645. 
288. Yung, T.K., Chan, K.C., Mok, T.S., Tong, J., To, K.F., Lo, Y.M. 2009. Single-molecule detection of epidermal growth factor receptor mutations in plasma by microfluidics digital PCR in non-small cell lung cancer patients. Clinical Cancer Research, 15:2076-2084.

289. Yurgelun, M.B., Kulke, M.H., Fuchs, C.S., Allen, B.A., Uno, H., Hornick, J.L., Ukaegbu, C.I., Brais, L.K., McNamara, P.G., Mayer, R.J., Schrag, D., Meyerhardt, J.A., Ng, K., Kidd, J., Singh, N., Hartman, A.R., Wenstrup, R.J., Syngal, S. 2017. Cancer Susceptibility Gene Mutations in Individuals With Colorectal Cancer. Journal of Clinical Oncology, 35(10):1086-1095.

290. Zhao, J., Li, P., Feng, H., Wang, P., Zong, Y., Ma, J., Zhang, Z., Chen, X., Zheng, M., Zhu, Z., $\mathrm{Lu}$, A. 2013. Cadherin-12 contributes to tumorigenicity in colorectal cancer by promoting migration, invasion, adhersion and angiogenesis. Journal of Translation Medicine, 11:288.

291. Zhong, X., Shen, H., Mao, J., Zhang, J., Han, W. 2017. Epigenetic silencing of protocadherin 10 in colorectal cancer. Oncology letters, 13(4):2449-2453.

292. Zhou, D., Tang, W., Su, G., Cai, M., An, H.X., Zhang, Y. 2017. PCDH18 is frequently inactivated by promoter methylation in colorectal cancer. Scientific Reports, 7(1):2819.

293. Zlobec, I., Bihl, M.P., Foerster, A., Rufle, A., Terracciano, L., Lugli, A. 2012. Stratification and Prognostic Relevance of Jass's Molecular Classification of Colorectal Cancer. Frontiers in Oncology, 2:7. 


\section{Publikācijas un ziṇojumi par darba tēmu}

\section{Zinātniskās publikācijas izdevumos, kas iekḷauti starptautiskajās datu bāzēs:}

1. Skuja, E., Butane, D., Nakazawa-Miklasevica, M., Daneberga, Z., Purkalne, G., Miklasevics, E. 2019. Deletion in metastatic colorectal cancer with chromothripsis. Experimental Oncology, 41(4):323-327. DOI: 10.32471/exp-oncology.2312-8852.vol-41-no-4.13841 (PubMed; SCOPUS).

2. Skuja, E., Gerina-Berzina, A., Hegmane, A., Zvirbule, Z., Vecvagare, E., Purkalne, G. 2018. Duration of previous treatment as a prognostic factor in $\mathrm{mCRC}$ treated with Trifluridin/Tipiracil (TAS102). Molecular and clinical oncology, 8:699-702N. DOI: 10.3892/MCO.2018.1600 (PubMed; Web of Science).

3. Skuja, E., Kalniete, D., Nakazawa-Miklasevica, M., Daneberga, Z., Abolins, A., Purkalne, G., Miklasevics, E. 2017. Chromothripsis and progression free survival in metastatic colorectal cancer. Molecular and clinical oncology, 6:182-186. DOI: 10.3892/MCO.2017.1123 (PubMed, Web of Science).

4. Skuja, E., Kalniete, D., Nakazawa-Miklasevica, M., Daneberga, Z., Purkalne, G., Miklasevics, E. 2018. Multiple deletions as a prognostic factor in metastatic colorectal cancer with chromothripsis. European Journal of Cancer, 103S1:e31 (Web of Science).

5. Skuja, E., Kalniete, D., Nakazawa-Miklasevica, M., Daneberga, Z., Abolins, A., Purkalne, G., Miklasevics, E. 2016. Chromosomal instability and chromothripsis as a prognostic factor for metastatic colorectal cancer. European Journal of Cancer, 69(1):S120-S121. DOI:10.1016/S0959-8049(16)32959-8 (Web of science).

\section{Zinātniski raksti Latvijā izdotos recenzējamos izdevumos:}

1. Daneberga, Z., Broka, E., Kalniete, D., Nakazawa-Miklasevica, M., Ustinova, M., Skuja, E., Purkalne, G., Miklasevics, E. 2015. Plasma miR-21 and miR-31 as predictive biomarkers for evaluation of therapeutic efficacy in metastatic colorectal cancer. Acta Chirurgica Latviensis, 15/1:3-7. DOI: 10.1515/chilat-2016-0001 (CrossRef).

2. Eglite, I., Nakazawa-Miklasevica, M., Purkalne, G., Skuja, E., Daneberga, Z., Gardovskis, J., Miklasevics, E. 2013. Comparative Study of Overall Survival of Hereditary (HNPCC) and Other Forms of Colorectal Cancer according to Family History. RSU Collection of Scientific Papers: Research articles in medicine \& pharmacy, 2013:12-21.

3. Skuja, E., Purkalne, G., Miklaševičs, E. 2012. Unresectable metastatic colorectal cancer treatment and survival - Pauls Stradins Clinical University Hospital experience. Acta Chirurgica Latviensis, 12:15-18. DOI:10.2478/v10163-012-0003-y (CrossRef).

\section{Zinātniski raksti ārvalstīs izdotos recenzējamos izdevumos:}

1. Skuja, E., Āboliņ̌š, A., Priedīte, I., Purkalne, G., Štrumfa, I., Vilmanis, J., Kalniete, D., Miklaševičs, E., Gardovskis, J. 2012. Pathological Complete Response in Young Colon Cancer Patient with a Large Liver Metastasis after FOLFOX-4/Bevacizumab Treatment. International Journal of Clinical Medicine, 3:307-310. DOI:10.4236/ijcm.2012.34061. (CrossRef). 


\section{Uzstāšanās starptautiskās konferencēs:}

1. Skuja, E., Kalniete, D., Nakazawa-Miklasevica, M., Daneberga, Z., Purkalne, G., Miklasevics, E. Multiple deletions as a prognostic factor in metastatic colorectal cancer with chromothripsis. 30th EORTC-NCI-AACR symposium, 13.11.18-16.11.18, Dublin. Abstract nr 69, Poster PB020 .

2. Skuja, E., Kalniete, D., Nakazawa-Miklasevica, M., Daneberga, Z., Abolins, A., Purkalne, G., Miklasevics, E. Chromosomal instability and chromothripsis as a prognostic factor for metastatic colorectal cancer. 28th EORTC-NCI-AACR symposium, 29.11.16-2.12.16, Munich. Abstract nr 366, Poster P045.

3. Skuja, E., Irmejs, A., Purkalne, G., Gardovskis, J., Miklaševičs, E. 2012. Survival of hereditary non-polyposis colorectal cancer (HNPCC) in Latvia. 1st International Baltic Hereditary Cancer Conference, Vilnius, Lithuania, 5.10. 2012:8.

\section{Uzstāšanās vietējās nozīmes konferencēs:}

1. Skuja, E., Kalniete, D., Nakazawa-Miklasevica, M., Daneberga, Z., Purkalne, G., Miklasevics, E. 2019. Chromothripsis as a prognostic marker in metastatic colorectal cancer. RSU International Conference on medical and health care sciences. 1.04.19-3.04.19, Rīga. Stenda referāts P96. Tēzes - RSU 10th scientific conferences abstract book 2019, Supp.1:21.

2. Skuja, E., Kalniete, D., Nakazawa-Miklasevica, M., Daneberga, Z., Abolins, A., Purkalne, G., Miklasevics, E. 2017. Chromothripsis kā metastātiska kolorektāla vēža prognostiskais faktors. RSU zinātniskā konference, 2017:123.

3. Skuja, E., Kalniete, D., Purkalne, G., Miklaševičs, E. 2013. KRAS un CEA kā metastātiska kolorektālā vēža prognostiskie markieri. RSU zinātniskā konference, 2013:279.

4. Skuja, E., Kalniete, D., Purkalne, G., Āboliņ̌s, A., Priedīte, I., Gardovskis, J., Miklaševičs, E. 2012. Metastātiska resnās zarnas vēža genoma struktūras analīze. RSU zinātniskā konference, 2012:273.

5. Skuja, E., Āboliņ̌s, A., Priedīte, I., Purkalne, G., Štrumfa, I., Vilmanis, J., Kalniete, D., Miklaševičs, E., Gardovskis, J. 2012. Pilna patoloğiska remisija pacientam ar metastātisku resnās zarnas vēzi. RSU zinātniskā konference, 2012:274.

6. Skuja, E., Geriṇa-Bērziņa,A., Kozirovskis, V., Purkalne,G. 2012. Kīmijterapijas raksturojums un efektivitāte pacientiem ar primāru metastātisku nerezecējamu kolorektālo vēzi P. Stradiṇa KUS Onkoloğijas klīnikā. RSU zinātniskā konference, 2012:27.

7. Skuja, E., Āboliňš, A., Priedīte, I., Purkalne, G., Štrumfa, I., Vilmanis, J., Kalniete, D., Miklaševičs. E., Gardovskis, J. 2011. Complete pathological response of colorectal liver metastasis after neoadjuvant chemotherapy - a case report. 5th Latvian Gastroenterology Congress, Riga. 12.11.2011. 


\section{Pateicības}

Izsaku lielu pateicību promocijas darba vadītājam, RSU Onkoloǵijas institūta vadītājam prof. Edvīnam Miklaševičam par doto iespēju izstrādāt un aizstāvēt disertācijas darbu viņa vadībā. Paldies par atbalstu, ticību, pacietîbu un uzticēšanos, kā arī par iespēju gūt jaunas zināšanas molekulārajā ǵenētikā un izmantot tās klīniskajā praksē.

Patiesā cieņā pateicos promocijas darba vadītājai prof. Guntai Purkalnei par motivāciju, profesionālo virzību un atbalstu. Prof. Gunta Purkalne ir onkologijas ķīmijterapijas nozares virzītāja Latvijā un ar savu piemēru ir pierādījusi, ka viss ir sasniedzams ar neatlaidīgu darbu un pacietību.

Paldies Miki Nakazawa-Miklaševičai par nenovērtējamo palīdzību statistisko datu apstrādē un datu analīzē. Izsaku pateicību RSU Onkoloǵijas institūta kolēǵiem, īpaši Dagnijai Butānei par ieguldījumu pētnieciskā darba izstrādē.

Paldies prof. Arnim Āboliņam par palīdzīibu audzēja paraugu sagatavošanas procesā, par atbalstu un uzmundrinājumu.

Pateicos P.Stradiņa KUS Onkoloǵijas klīnikas kolēǵiem - dr. med. Aijai GeriņaiBērziņai un dr. Viktoram Kozirovskim par atbalstu un atsaucību ikdienas darbā. Paldies RAKUS Latvijas Onkoloǵijas centra kolẹgém - asoc. prof. Alintai Hegmanei, dr. Žanetei Zvirbulei un dr. Evai Vecvagarei par līdzdalību publikācijas tapšanas procesā.

Visbeidzot, izsaku visdzị̄āko pateicību savam vīram $d r$. med. Armandam Sīviņam par mīlestību, atbalstu un rūpēm. 


\section{PIELIKUMI}


Ẽtikas komisijas aţ̦auja

Veidlapa Nr. E-9 (2)

Rīga, Dzirciema iela 16, LV-1007

Tel.67409137

Komitejas sastãvs

Kvalifikãcija Nodarbošanãs

1. Asoc. prof. Olafs Brũvers

2. Profesore Vija Sile

3. Docente Santa Purvina

4. Asoc. prof. Voldemărs Arnis

5. Profesore Regina Kleina

6. Asoc. prof. Guntars Pupelis

7. Asoc. prof. Viesturs Liguts

$\begin{array}{cl}\text { Dr.theo. } & \text { teologs } \\ \text { Dr.phil. } & \text { filozofs } \\ \text { Dr.med. } & \text { farmakologs } \\ \text { Dr.biol. } & \text { rehabilitologs } \\ \text { Dr.med. } & \text { patanatoms } \\ \text { Dr.med. } & \text { kirurgs } \\ \text { Dr.med. } & \text { toksikologs }\end{array}$

Pieteikuma iesniedzêis: $\quad$ Elĩna Skuja

RSU struktûrvienības Paula Stradip̣a KUS Onkoloǵijas klīnikas onkolog̉e

Pẽtijuma nosaukums:

Iesnieǧ̌anas datums:

Pêtrijuma protokols:

(X) Pētijuma veids:

(X) Pẽtijuma populācija:

(X) Informã̃cija par pẽttīumu:

(X) Piekrišana dalỉbai pětījumă:
„Vēža specifiskãs hromosomãlās aberãcijas kã metastãtiska kolorektâla vểža prognoze un ărstêŠanas efektivitătes predikatîvie biomarkieri "

01.09.2011.

Nav iebildumu

Literatûras izpễte, datu iegû̃ana un analíze, jaunas metodes izstrăde ḳimijterapijas efektivitătes monitorể̌anai, secinãjumi.

Pacienti, kuriem diognosticễts metastātisks kolorektāls audzējs un iegûti audi no operăcijas materiâla $(n=20)$

Ir

Ir

Citi dokumenti:

1.atł̣auja veikt pễtijumu

Lêmums: piekrist biomedicîniskajamp pềțựmam

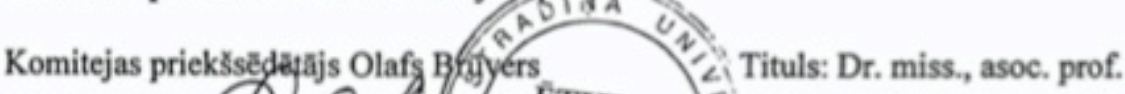

Paraksts

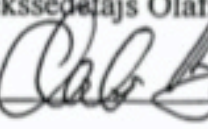

Etikas komitejas sễes datums: 06 10.8011. 


\section{PACIENTA INFORMĀCIJAS UN PIEKRIŠANAS VEIDLAPA}

PĒTĪJUMA NOSAUKUMS: Vēža specifiskās hromosomālās izmaiṇas kā metastātiska kolorektālā vēža prognozes un ārstēšanas efektivitātes prediktīvie biomarḳieri

\section{PROJEKTA REALIZĒTĀJS:}

P. Stradiņa Klīniskās universitātes slimnīcas CL Molekulārās biolog̣ijas un ǵenētikas nodaļa, VSIA Paula Stradiña KUS Onkologijas klīnika.

Lūdzu rūpīgi izlasiet esošo informāciju un, ja vēlaties, apspriediet to ar draugiem un radiniekiem. Lūdziet ārstam paskaidrot nesaprotamos vārdus vai sniegt papildu informāciju.

\section{Kas ir šis dokuments?}

Jūs tiekat aicināts/-a piedalīties zinātniskajā pētījumā, kas izvērtē genētiskās izmaiņas asin̄̄s resnās un taisnās zarnas vēža ārstēšanas gaitā. Pêtījumā plānots izpētît ǵenētiskās mutācijas audzēja šūnās, kā arī kontrolēt vēža šūnu DNS asinīs ārstěšanas laikā un pēc tās.

Šis dokuments tiek dēvēts par informētas piekrišanas veidlapu. Tajā tiks sniegta informācija par šo pētījumu. Ja Jūs nesaprotat kādu vārdu šajā piekrišanas veidlapā, lūdzu, jautājiet pētījuma ārstam, lai Jums informāciju izskaidro.

Ja piekritīsiet piedalīties šajā zinātniskajā pētījumā, pirms parakstāt šo informētās piekrišanas veidlapu, pārliecinieties, ka esat saṇēmis/-usi atbildes uz visiem saviem jautājumiem. Jums izsniegs parakstītu šīs veidlapas eksemplāru.

\section{Kāpēc mani lūdz piedalīties šajā pētījumā?}

Jūs lūdz piedalīties šajā pētîjumā, jo Jums pirmo reizi ir atklāts ļaundabīgs zarnu audzējs un ir iespējams novērtēt genētiskās izmaiņas audzēja šūnās un regulāri noteikt asinīs ārstēšanas laikā vēža DNS. Tas sniegs vērtīgu informāciju zinātniekiem, lai labāk izprastu slimību, dotu pilnīgāku ieskatu par nozīmētās ārstēšanas efektivitāti un, iespējams, attīstītu jaunus diagnostikas un ārstēšanas līdzekḷus.

\section{Kādā veidā es piedalī̌sos šajā pētījumā?}

Ja piekritīsiet piedalîties šajā pētījumā, medicīnas māsa Jums no vēnas paṇems $20 \mathrm{ml}$ asiṇu tāpat kā jebkurai citai analīzei. Jums tiks lūgta atļauja izmantot pētījuma mērķiem nelielu gabaliṇu no operācijas laikā vai diagnostiskās kolonoskopijas laikā izṇemtā audzēja materiāla.

Jums nepieciešamo ārstēšanu Jūs saņemsiet neatkarīgi no Jūsu izvēles piedalīties vai nepiedalīties pētījumā.

\section{Iespējamie ieguvumi:}

Piedalīšanās projektā nedos Jums tūlītēju labumu, bet gan kalpos jaunu zināšanu iegūšanai par resnās un taisnās zarnas vēzi un nākotnē, iespējams, var palīdzēt tiem cilvēkiem, kas slimos ar šo slimību.

Tiks ievēroti Helsinku deklarācijas pamatprincipi un pacientu datu aizsardzības likuma prasības. Pēc Jūsu vēlēšanās, projekta vadītājs sniegs informāciju par iegūtajiem izmeklējumu rezultātiem.

Pētījumam nepieciešamie izmeklējumi būs bezmaksas. Tāpat Jums nebūs tiesību pieprasīt maksu par audzēja paraugu nodošanu izpētei, kā arī par izpētes rezultātu izmantošanu.

\section{Iespējamie riski:}


Piedalīšanās pētījumā Jūsu veselībai nenodarīs l̦aunumu. Medicīnas māsa Jums no vēnas paņems $20 \mathrm{ml}$ asiņu tāpat kā jebkurai citai analīzei. Asins parauga ņemšanas vietā retos gadījumos var rasties neliels asins izplūdums, vai vēl retāk - neliels ādas lokāls iekaisums. Audzēja audu paraugs tiks ņemts no audu materiāla, kas iepriekš ticis izņemts operācijas vai diagnostiskas kolonoskopijas laikā. Audu parauga paņemšana nerada draudus Jūsu veselībai un neietekmē diagnostisko procedūru un ārstēšanas kvalitāti.

Ja pētîjuma dēḷ Jums attīstīsies kāda no komplikācijām, pētnieks nodrošinās, ka Jūs saņemat nepieciešamo ārstēšanu.

\section{Konfidencialitāte:}

Publicējot pētījuma rezultātus, Jūsu identitāte netiks atklāta. Jūsu dati un analīžu rezultāti tiks glabāti vietā ar ierobežotu pieejamību un netiks izsniegti ne Jūsu gimenes locekḷiem, ne apdrošinātājiem, ne darba devējiem.

\section{Brīvprātīga piedalīšanās:}

Jūsu piedalīšanās ir brīvprātīga un Jūs jebkurā laikā varat pārtraukt dalību resnās zarnas vēža izpētes projektā. Jūsu atteikšanās piedalīties šajā projektā neradīs Jums nekādas nevēlamas sekas.

\section{Kontaktpersona:}

Jūs jebkurā laikā varat uzdot jautājumus par šo pētījumu ārstam, kas Jūs uzaicināja piedalīties šajā pētījumā.

Kontakti: Dr. Elīna Skuja - darba tālrunis 67069218

\section{Paraksti:}

Esmu saņēmis/-usi un iepazinies/-usies ar rakstisku informāciju par šī projekta mērķi, saturu un iespējamiem riskiem. Uz visiem maniem jautājumiem esmu saṇēmis saprotamas un izsmel̦ošas atbildes. Man bija pietiekami daudz laika, lai pārdomātu savu lēmumu piedalīties pētījumā.

Parakstot šo dokumentu, Jūs apstiprināt, ka piekrītat piedalīties pētîjumā un, ka esat saṇēmis vienu šì dokumenta eksemplāru.

Pacienta vārds, uzvārds

Datums

Pacienta paraksts

DRUKĀTIEM BURTIEM

Pētnieka vārds, uzvārds

Datums

Pētnieka paraksts 
Pacienta piekrišanas veidlapa TAS-102 līdzjūtības zāḷu lietošanai

Pierilanas veidlapa lidzjüribas zāju lietỡanai-TAS-102 (trifluridīns-tipiracils) Kods: LVA-95005

\section{PIEKRIŠANAS VEIDLAPA \\ TAS-102 (TRIFLURIDĪNS-TIPIRACILS) LĪDZJÛTTĪBAS ZĀLUU LIETOŠANAI}

Ieteikums pacientam (vai likumiggajam pãrstãvim)

Ãrsts Jums ir piedāvājis lietot TAS-102 (trifluridīnu-tipiracilu), jo Jums ir diagnosticēts metastātisks kolorektălais vẽzis. Šis zâles, ko ražo TAIHO Pharmaceutical Co, Ltd (Kitajima rūpnĩca), Japăna,

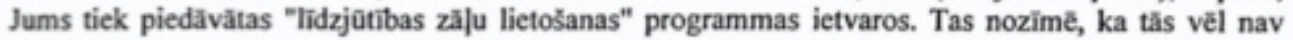

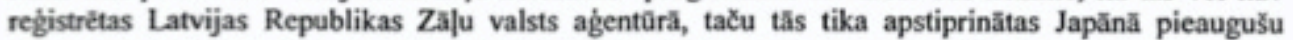
pacientu ărstểanai, kuriem ir neoperêjams progresējis vai recidivējošs kolorektālais vêzis, un ASV FDA tãs apstiprināja, lai ãrstētu progresējušu kolorektālo vẽzi.

Ãrsts Jũs ir informējis par క̌o zāju lietoక̌anu un to darbỉbu, iespējamām blakusparādībăm un risku. Veltiet laiku, lai pãrrunātu ar årstu visus neskaidros jautājumus, kã arī gađījumā, ja vēlaties uzzinăt

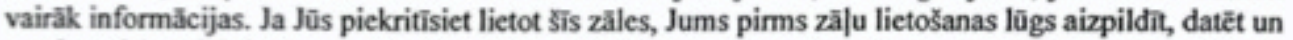
parakstit 2 šis piekrišanas veidlapas eksemplărus, no kuriem vienu vajadzēs saglabăt.

Blakusparāđỉbu, riska un đrošuma monitoringa apzināšanās

Parakstot šo veidlapu, es apzinos, ka (lūdzam atzīmēt tâlākos lodzinus):

4. Es piekrîtu lietot zăles TAS-102 (trifluridīnu-tipiracilu), ko Latvijas Zāju valsts aǵentûra vẽl nav apstiprinăjusi.

C. Mans ẫrsts man ir pilnỉbã izskaidrojis క̌o zā|u lietoక̌anu un sniedzis informãciju arĩ par to iedarbību, paredzamajiem riskiem, blakusparădỉăm un ieguvumiem, un es zinu, ka gadījumā, ja turpmăk man radisies jautăjumi, es varu uzdot tos savam ărstam.

口. Man ir bijusi iespēja uzdot jautājumus par jebkãdu iespējamo kaitējumu, kas man varêttu rasties ãrstě̌̌anas rezultātă, un esmu saṇēmis apmierinošas atbildes.

[1 Es piekrîtu reguläriem radiolog̉iskiem un biolog̉iskiem izmeklējumiem vai jebkădiem citiem mana ărsta ieteiktiem izmeklęjumiem, lai părliecinătos par TAS-102 (trifluridīna-tipiracila) drošumu un/vai efektivităti mană organismã.

9. Man ir sniegta pieejamā informācija par TAS-102 (trifluridīnu-tipiracilu; skatīt 1. pielikumu).

Personiskãs medicīniskās dokumentāeijas un personas datu izmantošanas akceptě̌̌ana

Parakstot Šo veidlapu, es apzinos, ka (lũdzam atzīmêt tălākos lodzinus):

Es piekritu manu personas datu apstrādei. Es esmu informěts, ka jebkuri mani personas dati, kas būs apkopoti manas ārstē̌̌anas laikā, bûs kodēti, ka mana identitāte nekādā gadijumā netiks izpausta un ka jebkāda apkopotă informācija paliks konfidenciāla. Es piekrîtu, ka manu medicīnisko informāciju un citus ar manu ārstē̌̌anu saistîtos personas datus var aplūkot un apstrā̃āt Servier grupas părstãvji un cilvě̉i, kas ir tieši vai netieši iesaistîti jebkāda veida līdzjūtỉbas zāju lietošana Servier grupas uzdevumă vai sadarbībā ar to, êtikas komitejas dalỉbnieki un kompetento iestāž̃u părstãvji.

․ Es esmu informēts un piekritis, ka mani personas dati var tikt nosũtîti ārpus ES un ka tos var apstrãdāt:

- Cilvēki, kuri tieక̧i vai netieŠi ir iesaistıti jebkāda veida līdzjûtîbas zā|u lietošanā Servier grupas uzdevumă. 
Pierišanas veidlapa lïdzjūtibas zä|u lietojanai-TAS-102 (trifluridinns-tipíracils)

Kods: LVA-95005

Es esmu informễts, ka mani personas dati tiks părsûtiti ẵpus ES vai ES iekšienē un ka tos

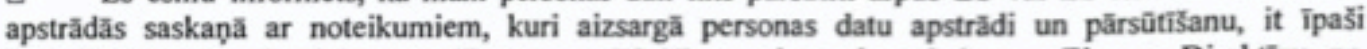
Francijas 1978. gada 6. janvăra likumu nr. 78-17 par datu aizsardzibu un Eiropas Direktĩvu nr. 95/46/CE par datu aizsardzibu.

ㅁ Es esmu informēts, ka saskanā ar Francijas 1978. gada 6. janvãra likuma nr. 78-17 par datu aizsardzỉbu 38. un turpmākajiem pantiem un ši likuma grozijumiem man ir tiesibas piekjūt, mainīt un

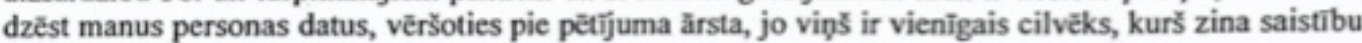
starp manu pacienta numuru un manu identităti.

\section{Zạu izmaksu akceptě̌̌ana}

Parakstot šo veidlapu, es apzinos, ka:

D Es esmu informêts, ka Servier grupa zāles TAS-102 (trifluridins-tipiracils) man nodrošinās bez maksas.

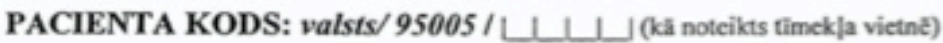

\section{PACIENTA VĀRDS UN UZVĀRDS:}

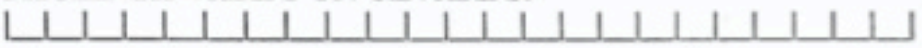

Pacienta paraksts: Datums:

\section{LIECINIEKA VĀRDS UN UZVĀRDS (ja piemērojams)}

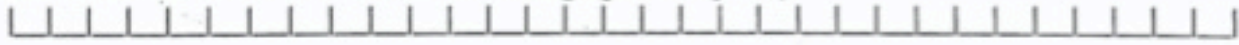

Liecinieka paraksts:

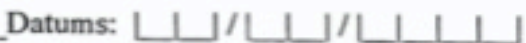

Ārsta vãrds un uzvărds:

Ārsta paraksts: Datums:

Viens parakstītais informācijas un piekrišanas veidlapas eksemplārs jāizsniedz pacientam, bet otrs parakstitais eksemplārs jāsaglabā pacienta medicīniskajā dokumentācijā. 


\section{Informācija pacientam}

Pieriłanas veidlapa liddyüribas zā|u lietosanai-TAS-102 (trifluridins-tipiracils)

Kods: $L V A-95005$

\section{1. pielikums - INORMĀCIJA PACIENTAM}

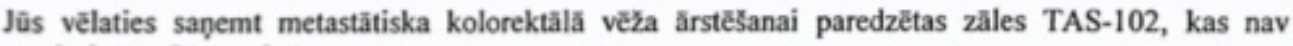
apstiprinātas Jüsu valstî.

Pirms piekritat Šai ãrstểanai, ir svarīgi, lai Jūs izlasītu un izprastu tālāk sniegto informāciju par TAS102. Ja Jums ir jautăjumi par క̌o ārstē̌̌anu, lũdzu, konsultējieties ar ãrstu un raugieties, lai pirms İ̌muma pienemamas par turpmākajām darbỉbām, bûtu saṇemtas atbildes uz visiem Jüsu jautăjumiem.

TAS-102 ir pētảmãs zãles, kuras izstrāđajijis uzp̣ēmums Taiho. No 2015. gada 24. jülija klīniskajos pẽtrjumos (Taiho sponsorêtos vai Pẽtnieka săktos) ãrstēti kopumă 2212 pacienti. Pašlaik TAS-102 ir apstiprināts un picejams tirgû Japãnã un ASV. Uzp̣ēmums Taiho ir iesniedzis pieteikumu reǵistrăcijai Eiropas Savienibã (ES)/ Eiropas Ekonomikas zonă.

\section{Ärstě̌̆ana ar šìm zâlēm}

Jũs sañemsiet TAS-102 divas reizes dienā 5 dienas ar 2 dienu pãrtraukumu 2 nedē|u garumã. Pēc tam seko 14 dienas, kad Šis zāles nelieto. Šăds ărstē̌̌anas cikls tiek atkărtots ik pềc 28 dienăm. TAS-102 daudzums, kảdu Jũs sanemsiet, ir atkarīgs no Jūsu auguma garuma un ķermena masas.

TAS-102 jālieto kopã ar glāzi udens 1 stundas laikă pẽ̃c ẽdienreizes pabeigšanas (no rita un vakarā).

Jũs varat turpināt lietot TAS-102, kamēr vien Jûsu ărsts uzskata, ka Jums ir labums no tã, vai lĩdz brìdim, kad Jūs izvêlaties părtraukt lietot s̄is zāles.

Viens cikls (28 dienas) ir veidots šădi.

1. Iidz 5. diena: TAS-102 iekškīgi 2 reizes dienā, pirmo devu lietojot no rîta katra cikla 1. dienă un pểeçjo devu lietojot 5 . dienas vakarā.

6. lī̉z 7. diena: Atgūsanās (TAS-102 nelieto)

8. līdz 12.diena: TAS-102 iekškīgi 2 reizes dienă, pirmo devu lietojot no rīta katra cikla 8. dienă un pẽdējo devu lietojot 12 . dienas vakară.

13. līdz 28. diena: Atgûsanăs (TAS-102 nelieto)

Atkarỉbă no Jûsu reakcijas uz ãrstē̌̌anu ārsts var lemt samazināt Jums lietojamo devu. Tādā gadijumă ârsts paskaidros, kăpēe tã ir noticis, un arī sniegs informāciju par jauno devu, kas Jums jălieto năkamajă ărstểanas ciklā.

\section{Blakusparādibas vai risks}

Tiks rūpīgi vêrots, vai Jums nerodas kādas blakusparādỉbas. Tomẽr ãrsti nezina visas blakusparāđỉbas, kãdas var rasties. Daudzas blakusparădibas izzûd, părtraucot pêtíjuma zăju lietoక̌anu, taču dažos gađijumos blakusparădỉbas var būt smagas, ilgstošas vai neizzūdošas, vai arĩ tas var pastiprinăties, izraisot năves iestāక̌anos. Ārsts Jums var lietot zăles, kas nav da|a no pētījuma, lai palīdzētu mazināt blakusparădỉbas; šis zāles uzskata par atbalstošo aprūpi. Tomēr par visăm blakusparādỉbām, kas Jums rodas, Jums jāziṇo pētijuma ãrstam. 


\section{a) Kădas ir iespējamãs TAS-102 blakusparådibas?}

No 2015. gada 24. jūlija klīniskajos pẽtijumos (Taiho sponsorētos vai Pētnieka săktos) ãrstêti kopumā 2212 pacienti. . Tălāk minētās blakusparādỉbas ietver blakusparādỉbas, kas novērotas šiem pacientiem. Tomêr tālāk nav uzskaititas visas blakusparädỉbas, jo nav uzskaititas nebũtiskas retas blakusparãdibas, bet ir minêtas smagas retas blakusparādības. Sarakstã iekjautās blakusparā̃ỉbas gan var būt saistītas ar TAS-102, gan var nebôt saistitas ar Sెim zālēm, un Jums var bût arī dažas citas neminêtas blakusparādibas.

Lai gan daudzas no blakusparādỉbām, par kurām zį̣oja, bija vieglas līdz vidēji smagas, dažas blakusparădỉbas var klût smagas un dzīvỉbai bīstamas, un tās var arī pastiprinăties, un rezultātā var iestāties nãve.

\section{i) Liela iespējamiba, rodas $>20 \%$ dalibnieku (jebkuras pakãpes blakusparadibas)}

- Kunģa-zarnu trakts: slikta dū̌̌a, vemšana, caureja.

- Asinis: samazinăts leikocītu/ neitrofilo leikocītu skaits (leikocīti ir svarīgi, palīdzot cilvēkiem cīnīties ar infekcijām vai novēršot tās); samazināts eritrocītu skaits (anēmija). Eritrociiti ir svarīgi, lai asinīs tiktu pārnēsāts skābeklis, un samazināts to skaits var izraisît tãdus simptomus kã nogurums vai elpas trūkums

- Vispärēji: nogurums.

- Vielmaiña: ẽstgribas zudums.

- Infekcija: infekcijas, piemēram, asins infekcija (var būt letāls iznākums), plaušu, iegurna, acu, urīncelu, zarnu trakta, ãdas, aknu/žultscelu, ar medicīnas ierīci saistîtas infekcijas.

i) Biežas, rodas 3-20\% dalíbnieku (jebkuras pakāpes blakusparãdibas)

- Kunğa-zarnu trakts: Čũlas mutē (stomatīts), aizcietējums, sāpes vēderā, gremoŠanas traucêjumi

- Asinis: samazinăts trombocītu skaits (trombocīti ir svarīgi, palīdzot asinīm sarecēt, kad ir asipošana).

- Āda: matu izkrišana, izsitumi (ãdas krāsas vai audu izmaiṇas, iespējama tulznu veidoక̌anās un ādas lobīsanās)

- Nieres: olbaltumvielu noplũde urīnã

- Nervi: garšas sajūtas părmainas, galvassāpes

- Balsta un kustíbu aparãts: muguras sãpes, locìtavu sãpes.

- Vispărēji: drudzis, nespēks.

- Vielmaipa: samazināts olbaltumvielu daudzums asinīs.

- Psihe: trauksmainiba - Aknas: patoloĝisks augsts enzīmu, kas veidojas aknăs, līmenis (kas nozīmē, ka ir
traucēta aknu darbỉba) 
Pierisanas veidlapa lidzjüüibas zälu lietolanai-TAS-102 (trifluridins-tipiracils)

Kods: $L V A-95005$

iii) Retas, bet smagas blakusparàdibas, kas rodas $<3 \%$ dalíbnieku (3. vai augstāka pakāpe):

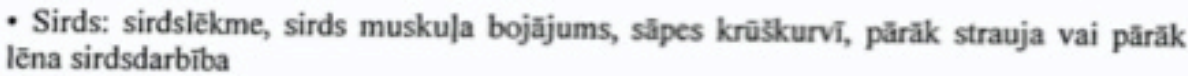

- Aknas: aknu bojājums, dzeltena ādas vai acu krāsa (dzelte).

- Nieres: nieru bojājums, asinis urīnā.

- Galvas smadzenes: ietekme uz galvas smadzepu vai nervu darbïbu, krampji, pazeminăts apzip̧as limenis, asins trombs.

- Kungáa-zarnu trakts: Resnās zarnas iekaisums (simptomi ir sāpes vẽderā, caureja un izkărnijumi ar asinīm), patolog̉isks savienojums starp kunǵa-zarnu traktu un citãm

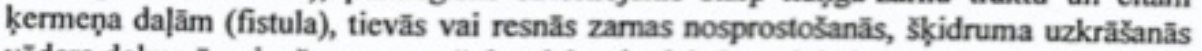
vẽdera dobumă, asiṇošana, zarnu củla, aizkuṇǵa dziedzera iekaisums.

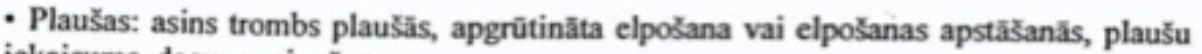
ickaisums, deguna asipošana.

- Vielmaiña: podagra (augsts urīnskābes limenis ar tãdiem simptomiem kã sarkanas jutigas, karstas un pietūkušas locîtavas, dehidratāicija

- Asinsvadi: samaṇas zaudē̌̌ana, asins trombs kājā, pazeminăts asinsspiediens, asins recē̌̌anas traucêjumi, karstuma vilpi.

- Nervi: reibonis, notirpums un tirpక̌ana.

- Balsta un kustibu aparãts: musku|u sãpes.

• Vispãrēji: gripai līdzĩgi simptomi, vispãrējāss fiziskãs veselỉbas pasliktināక̌anās, kāju pietūkums

Pẽcreg̉istrăcijas dati

- TAS-102 ar nosaukumu Lonsurf囚 kop\$ 2014. gada 26. maija ir bijis piecjams Japănas tirgū. Ãzijā klīniskajos pễtijumă un klīniskajā praksē Lonsurf sạ̣ēmuši 7000 pacientu. Šiem pacientiem novērotas క̌ădas blakusparãdỉbas.

- Asinis: drudzis ar samazinãtu neitrofilo leikocitu skaitu (var būt letāls iznākums); asins recē̌̌anas traucễjumi (var bũt letāls iznākums); kaulu smadzepu darbỉbas nomākums un nespēja veidot pietiekamu skaitu eritrocitu, leikocitu vai trombocitu (var bût letāls iznākums); samazinăts trombocītu skaits (var būt letāls iznākums); samazināts eritrocîtu, leikocîtu un trombocîtu skaits vienlaikus; samazinăts eritrocîtu un leikocitu/neitrofilo leikocitu skaits.

- GremoŠanas sistēma: inficêta fistula; caureja; asip̣ojoša GI cọla; tievãs vai resnās zarnas nosprostojums; slikta dūSa; tievãs zarnas plïsums; vemšana.

- Acis: radzenes bojajums.

- Vispārểi: drudzis; noguruma sajūta; nãve.

- Sirds: sirds mazspēja, paātrināta sirdsdarbỉba.

- Infekcija: infekcija; infekcija asinīs; šoks; urīnceju infekcija

- Nieres: pavājinăta nieru darbība.

- Aknas: dzeltena ãdas vai acu krã̃sa (dzelte); žultspūšja infekcija, aknu darbỉbas traucểjumi 
Pierisanas veidlapa lidzjüribas ză|u lietolanai-TAS-102 (trifluridins-tipiracils)

Kods: LVA-95005

- Metabolisms: elektrolitu lídzsvara traucējumi.

- Nervu sistễna: asins trombs galvas smadzenēs (var bũt letâls iznalkums).

- Elpošanas sistêma: pneimonija (var bût letăls iznākums); intersticiāla pneimonija (var bû̃t letāls iznākums); respiratorã distresa sindroms (var bôt letāls iznākums); asins trombs plausăs.

\section{b) Ar gratniecibu saistitais risks}

Laikā, kamẽr lietošanas humãnu apsvêrumu dẹ| programmă lietojat TAS-102 un vêl 6 mễneక̌us pẽc

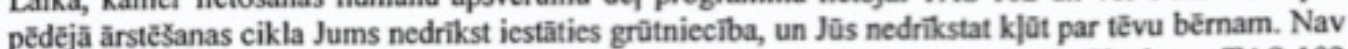
zinăms, kă TAS-102 ietekmể augla attīstibu vai zỉdaini, kuru baro ar krûti. Sievietes TAS-102 lietošanas laikā nedrikst barot bērnu ar krūti.

Ja Jums var bũt bērni (gan vĩriešiem, gan sievietễm), Jums jāpiekrit lietot efektĩvu kontracepcijas

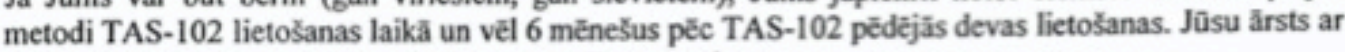
Jums părrunăs, kāda ir efektīvākā kontracepcijas metode.

\section{Kas notiek, ja kḷast piecjama jauna informácija?}

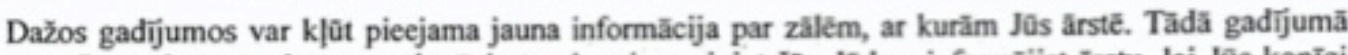
ărsts Jums darīs to zinămu, vai arī, ja to pirmais uzziniet Jūs, lûdzu, informējiet ărstu, lai Jūs kopĩgi

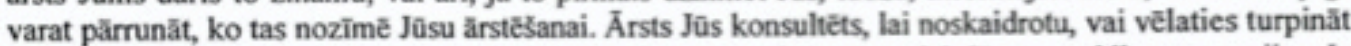
ărstēties. Tādă gadijumā Jums lūgs parakstit jaunu, mainitu కis piekrỉanas veidlapas versiju. Ja

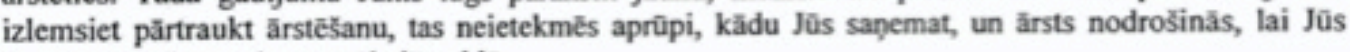
tiktu ârstêts Jums piemẽrotăkajă veidā.

Pamatojoties uz jauno informãciju, ărsts var arī lemt, ka Jüsu labăkajā̄s interesēs î̉ pārtraukt Jũsu

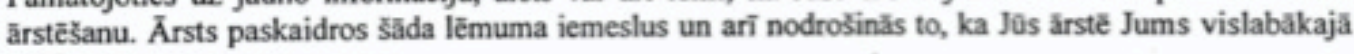
veida.

\section{Brīvprātīga piekrišana/ tiesỉbas părtraukt ârstê̌sanu}

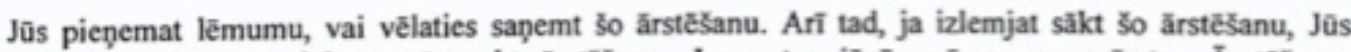

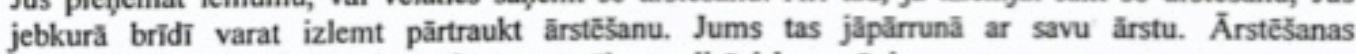
părtraukšana lểmums neietekmês Jūsu turpmāko medicinisko aprūpi.

Jūsu ārsts var părtraukt ārstē̌̉anu, ja uzskata, ka tas ir Jũsu labākajās interesês vai ja Jũs ărstểanas laikã nevarat ievêrot norãdījumus.

\section{Kas notiek péc ârstě̌anas?}

Ãrstê̌̉anas ilgums bũs atkarīgs no Jüsu reakcijas uz TAS-102. Jũs varat turpinẵ ărstē̌̉anos tik ilgi, kamēr ärsts uzskata, ka güstat no tãs labumu. Ārstē̌̉anu arĩ bez Jôsu piekriłanas var părtraukt, ja pasliktinās Jūsu veselîbas stāvoklis, ja nepiepemamu blakusparädību đē| izrādās, ka zãles netiek labi panestas, vai ja Jûs neievērojat norădijumus par ărstē̌̌anu, ja kJûst pieejama jauna informãcija, kas liecina, ka Jũs vairs negũstat labumu no ãrstē̌̌anas, vai ja Jûs neesat devis brīvprātīgu informěto piekrišanu. 
PieriSanas veidlapa lidizjûtribas ză|lu lietosanal-TAS-102 (trifluridins-tipiracils)

Kods: $L V A-95005$

Jautājumi

Ja Jums ir kädi jautājumi par šo lietošanas humāmu apsvērumu dēl programumu, tâs procedūrām, ar to saistītajiem riskiem un ieguvumiem vai alternatîviem ärstēsanas veidiem, lüdzam sazināties ar Jüsu ärstëšanā iesaistîto ầrstu vai personālu.

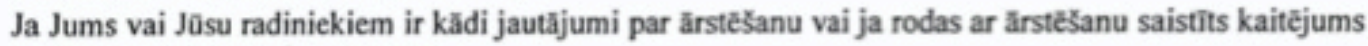
veselībai, Jums jăsazinăs ar ārstu.

Ja Jums nepieciešama neatliekamã palīdzỉba vai ja Jûs nonăkat slimnică, lùdzu, informējiet ărstu, ka piedalāties programmā, kura tiek veikta ãrstē̌̉ana ar TAS-102.

Lūdzu, parakstiet Šo piekrišanas veidlapu tikai pẽ̃c tam, kad Jums ir bijusi iespēja uzdod jautājumus un kad esat sañêmis pieņemamas atbildes uz visiem saviem jautăjumiem. 